$$
\begin{gathered}
\text { UNIVERSIDADE DE SÃO PAULO } \\
\text { ESCOLA DE ARTES, CIÊNCIAS E HUMANIDADES } \\
\text { PROGRAMA DE PÓS-GRADUAÇÃO EM MUDANÇA SOCIAL E PARTICIPAÇÃO } \\
\text { POLÍTICA }
\end{gathered}
$$

RODRIGO CRIVELARO

O que a rebeldia teima? Capturas e resistências nas conferências de juventude em Santa Bárbara d'Oeste 
RODRIGO CRIVELARO

\title{
O que a rebeldia teima? Capturas e resistências nas conferências de juventudes em Santa Bárbara d'Oeste
}

\author{
Versão corrigida
}

Dissertação apresentada à Escola de Artes, Ciências e Humanidades da Universidade de São Paulo para obtenção do título de Mestre em Ciências pelo Programa de Pós-graduação em Mudança Social e Participação Política.

Versão corrigida contendo as alterações solicitadas pela comissão julgadora em 7 de março de 2016. A versão original encontra-se em acervo reservado na Biblioteca Digital de Teses e Dissertações da USP (BDTD), de acordo com a Resolução CoPGr 6018, de 13 de outubro de 2011.

Área de Concentração:

Mudança Social e Participação Política

Orientadora:

Prof. ${ }^{a}$ Dr $^{a}$. Elizabete Franco Cruz

São Paulo 
Autorizo a reprodução e divulgação total ou parcial deste trabalho, por qualquer meio convencional ou eletrônico, para fins de estudo e pesquisa, desde que citada a fonte.

O que a rebeldia teima? Capturas e resistências nas conferências de juventude em Santa Bárbara d'Oeste / Rodrigo Crivelaro ; orientadora, Elizabete Franco Cruz. - São Paulo, 2016 $301 \mathrm{f}$. : il

Dissertação (Mestrado em Ciências) - Programa de PósGraduação em Mudança Social e Participação Política, Escola de Artes, Ciências e Humanidades, Universidade de São Paulo

Versão corrigida

1. Jovens. 2. Jovens - Conferências - Santa Bárbara d'Oeste (SP). 3. Participação. I. Cruz, Elizabete Franco, orient. II. Título

CDD 22.ed. -305.235 
Crivelaro, Rodrigo

O que a rebeldia teima? Capturas e resistências das juventudes nas conferências

Dissertação apresentada à Escola de Artes, Ciências e Humanidades da Universidade de São Paulo para obtenção do título de Mestre em Ciências do Programa de Pós-Graduação em Mudança Social e Participação Política.

Área de Concentração:

Mudança Social e Participação Política

Aprovado em: 07 / 03 / 2016.

\title{
Banca Examinadora
}

\author{
Prof. Dr. Romualdo Dias \\ Universidade Estadual Paulista \\ Prof. Dr. Ricardo de Castro e Silva \\ Taba-espaço de vivência e convivência do adolescente \\ Prof. Dr. Luís Antonio Groppo \\ Universidade Federal de Alfenas
}


Á minha família por acreditar em mim e não medir esforços para que eu pudesse atingir meus sonhos e objetivos acadêmicos, me ensinando a ter coragem e garra, em especial nos momentos mais difíceis, me dando a certeza de nunca estar sozinho e sempre me acolhendo com carinho, cuidado e afeto.

À minha esposa Claudia, com carinho, amor, admiração e gratidão por sua compreensão, desvelo, apoio e sacrifícios em minha ausência ao longo do período de elaboração desta pesquisa.

A todos os jovens que nunca deixaram de acreditar na possibilidade de mudar a sociedade a partir da participação e, com rebeldia, ousam, sonham e criam. 


\section{Agradecimentos}

A Deus pelo dom da vida.

Aos meus pais, Lucia e Dino por sempre acreditar em mim e por, desde criança, sempre me motivarem a sonhar e lutar por minha trajetória acadêmica.

À minha esposa Claudia, pela paciência e compreensão nas constantes ausências em que dedicava tempo a esta produção.

Aos meus irmãos Rondinelli e Renan, pelas parcerias, carinho e admiração.

À Elizabete Franco Cruz, pela amizade, carinho, cuidado, paciência por me mostrar novas possibilidades de compreender a militância e meu objeto de estudo e por aceitar partilhar esta trajetória cheia de voos e pousos.

Aos companheiros e companheiras do Grupo de Pesquisa em Saúde Coletiva, Educação e Relações de Gênero, Mari, Alexandre, Elis, Thiago, Helena e Raquel pelas partilhas trocas e reflexões que muito contribuíram ao longo desta trajetória.

Ao amigo professor Walderes Brito (in memorian) que me incentivou e orientou durante o processo seletivo ao Programa de Mestrado em Mudança Social e Participação Política com dicas preciosas que me possibilitaram chegar até aqui.

Aos professores da $7^{a}$ turma de Especialização em Juventude no Mundo Contemporâneo da Rede Brasileira de Centros e Institutos de Juventude pelas reflexões propiciadas durante o curso.

Aos professores Dr. Ricardo Castro e Silva e Dr. Romualdo Dias pelas contribuições, orientações e críticas ofertadas durante a banca de qualificação ou através de partilha de textos para orientar esta reflexão.

Ao professor Dr. Luís Antonio Groppo, pelas contribuições ofertadas no momento de encontro, incluindo as contribuições para pensar o projeto que me possibilitou ingresso no mestrado e pela partilha de textos. 
Aos companheiros e companheiras do Grupo de Trabalho "A Juventude quer viver" da Pastoral da Juventude por confiar a mim a representação da Pastoral da Juventude na Comissão Organizadora Estadual possibilitando aprofundar meus conhecimentos e reflexões acerca das conferências de juventude e conhecer e partilhar novas relações de poder e táticas de guerrilha ao lado de novos companheiros.

Ao Conselho Municipal de Juventude (CoMJuv) gestões 2011-2014 e gestão 2014-2016, pelas partilhas, brigas, lutas e ousadias na construção das políticas públicas de juventude em Santa Bárbara d'Oeste -SP.

Aos meus amigos (as) de vida e companheiros de militância Iraci, Roberio, Dito e Tom, partícipes da minha formação militante através de horas de conversas, sonhos e utopias.

Aos meus amigos Andréa Nunes, Eduardo Gomes, Ana Paula Silva, Douglas Beiro, Fábio Nunes, Waldísia e Simone Stefani pela amizade e afeto nos momentos de partilha da vida.

À amiga, professora e madrinha Simeire pelo incentivo e provocações para continuidade da trajetória acadêmica, desde o manual e a inscrição para o vestibular, para acesso a graduação.

Aos companheiros e às companheiras que, a partir de suas narrativas, enriqueceram as análises e reflexões desta pesquisa.

Ao Instituto Federal de Educação, Ciência e Tecnologia de São Paulo, que me possibilitou dedicar maior período à construção e produção desta dissertação. Aos companheiros e companheiras de trabalho do Campus Hortolândia, que me alimentaram com reflexões e ajuda importante durante a caminhada, com apoio e incentivo quando o fim ainda parecia distante.

A todos os jovens, a todas as jovens e aos (as) militantes não jovens que encontrei ao longo desta trajetória de participação e formação nas conferências nacionais de juventude. 
Anda,

quero te dizer nenhum segredo, falo neste chão da nossa casa. Vem que tá na hora de arrumar.

Tempo, quero viver mais duzentos anos, quero não ferir meu semelhante nem por isso quero me ferir.

Vamos precisar de todo mundo pra banir do mundo a opressão, para construir a vida nova vamos precisar de muito amor.

A felicidade mora ao lado e quem não é tolo pode ver.

A paz na Terra amor, o pé na terra, a paz na terra amor o sal da Terra.
És o mais bonito dos planetas tão te maltratando por dinheiro, tu que és a nave, nossa irmã.

Canta, leva tua vida em harmonia e nos alimenta com seus frutos, tu que és do homem a maçã.

Vamos precisar de todo mundo Um mais um é sempre mais que dois Pra melhor juntar as nossas forças É só repartir melhor o pão Recriar o paraíso agora Para merecer quem vem depois...

Deixa nascer, o amor Deixa fluir, o amor Deixa crescer, o amor Deixa viver, o amor O sal da terra 


\section{RESUMO}

CRIVELARO, Rodrigo. O que a rebeldia teima? Capturas e resistências nas conferências de juventude em Santa Bárbara d'Oeste. 2016. 301f. Dissertação (Mestrado em Mudança Social e Participação Política) - Escola de Artes, Ciências e Humanidades, Universidade de São Paulo, São Paulo, 2016. Versão corrigida.

Diante do boom discursivo sobre juventude e participação, esta pesquisa propõe-se a problematizar e conhecer os sentidos atribuídos às conferências, ao ser jovem/juventude e à participação juvenil a partir das conferências de juventude em Santa Bárbara d'Oeste. O referencial teórico utilizado são estudos sobre juventude, conferência e participação, e obras de autores que dialogam com a perspectiva pós estruturalistas como Michel Foucault e Deleuze Guattari. Utilizando da cartografia como método de pesquisa, adotou-se três procedimentos metodológicos: entrevistas, transcritas e analisadas a partir de mapas dialógicos; registro da experiência do pesquisador como participantes e revisita aos relatórios finais das conferências de juventude. A partir daí são feitos voos e pousos tendo como territórios as conferências de juventude, a participação e o jovem/juventude o que possibilitou observar as capturas presentes nestes espaços de participação, onde as tecnologias do eu atuam em processos de subjetivação, responsáveis por produzir discursos sobre jovem, juventude e participação. Por fim, as considerações finais ofertam a possibilidade de compreender, que em meio à captura e às relações de poder nelas engendradas, os jovens, partindo da rebeldia e participação, produzem resistências e encontram novas formas de subjetivar a juventude, rejeitando o rótulo de juventude problema, ressignificam o espaço estriado das conferências e lançam novas perspectivas e possibilidades de participação rizomática.

Palavras-chave: Juventude. Jovem. Conferências Nacionais e Municipais. Participação. Relações de poder. 


\begin{abstract}
CRIVELARO, Rodrigo. What insists rebellion? Catches and resistance in the youth conference in Santa Barbara d'Oeste. 2016 301f. Dissertation (Master of Social Change and Political Participation) - School of Arts, Sciences and Humanities, University of São Paulo, São Paulo, 2016. corrected version.
\end{abstract}

Before the boom discourse on youth and participation, this study proposes to discuss and know the meanings attributed to conferences, to be young / youth and youth participation from the youth conference in Santa Barbara d'Oeste. The theoretical framework used are studies on youth, and conference participation, and works of authors that dialogue with post structuralist perspective as Michel Foucault and Deleuze Guattari. Using the mapping as a research method, adopted three methodological procedures: interviews, transcribed and analyzed from dialogical maps; record of the researcher's experience as participants and revisits the final reports of the youth conference. From then on are made flights and landings having as youth conferences territories, participation and youth / youth which made it possible to observe the present catches in these spaces of participation where the technologies I work in subjective processes, responsible for producing speeches about youth, youth and participation. Finally, the concluding remarks proffer the possibility of understanding that through the capture and power relations in them engendered, young people, starting from the rebellion and participation produce resistance, and find new ways to subjectively youth, rejecting the label of youth problem, resignify the striated space of conferences and launched new perspectives and possibilities of rizomatic participation.

Keywords: Youth. Young. National and Municipal Conference. Participation. Power relations. 


\section{RESUMEN}

CRIVELARO, Rodrigo. Lo que insiste en la rebelión? Las capturas y la resistencia en la conferencia de la juventud en Santa Bárbara d'Oeste. 2016 301f. Tesis (Maestría en Cambio Social y Participación Política) Escuela de Artes, Ciencias y Humanidades de la Universidad de São Paulo, São Paulo, 2016. versión corregida.

Antes del discurso auge en la juventud y la participación, este estudio propone discutir y conocer los significados atribuidos a las conferencias, a ser jóvenes / jóvenes y participación de los jóvenes de la conferencia de la juventud en Santa Bárbara d'Oeste. El marco teórico utilizado son los estudios sobre la juventud y participación en conferencias, y las obras de los autores que el diálogo con perspectiva post estructuralista como Michel Foucault y Deleuze Guattari. Utilizando el mapeo como método de investigación, adoptado tres procedimientos metodológicos: entrevistas, transcrita y analizada a partir de mapas dialógicos; registro de la experiencia del investigador como participantes y revisita los informes finales de la conferencia de la juventud. A partir de entonces se hacen vuelos y aterrizajes que tienen como conferencias juveniles territorios, la participación y la juventud / jóvenes que permitió observar las actuales capturas en estos espacios de participación donde las tecnologías que trabajan en procesos subjetivos, responsables de la producción de discursos sobre la juventud, la juventud y la participación. Por último, las observaciones finales proferir la posibilidad de comprender que a través de las relaciones de captura y de poder en ellas engendrada, los jóvenes, a partir de la rebelión y la participación producen resistencia y encontrar nuevas maneras de forma subjetiva la juventud, el rechazo de la etiqueta de la juventud problema, resignificar el espacio estriado de conferencias y lanzó nuevas perspectivas y posibilidades de participación rizomática.

Palabras clave: Juventud. Young. Nacional y Municipal de Congresos. Participación. Las relaciones de poder. 


\section{LISTA DE FIGURAS}

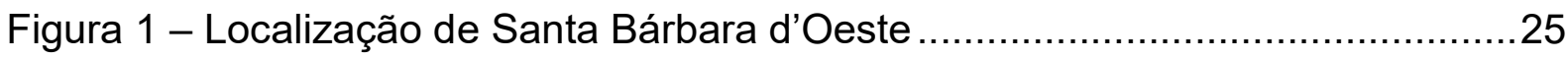

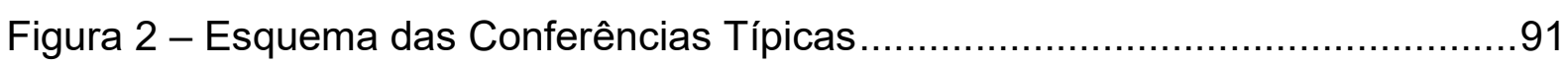

Figura 3 - Identidade visual $1^{\text {a }}$ Conferência Nacional de Juventude .....................119

Figura 4 - Identidade Visual da $2^{\text {a }}$ Conferência Nacional de Juventude...................122

Figura 5 - Logo da $3^{a}$ Conferência Nacional de Juventude ...................................125

Figura 6 - Show durante a $3^{\text {a }}$ Conferência Nacional de Juventude ........................126

Figura 7 - GT Educação (esquerda) e Momento de abertura da $1^{\text {a }}$ Conferência

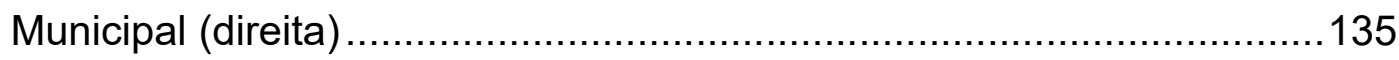

Figura 8 - Identidade visual da $2^{\text {a }}$ Conferência Municipal de Juventude ...............137

Figura 9 - Abertura da $2^{\text {a }}$ Conferência Municipal de Juventude ...........................138

Figura 10 - Ciranda durante Conferência Livre realizada pela PJ .........................138

Figura 11 - Identidade visual da $3^{\text {a }}$ Conferência Municipal de Juventude...............140

Figura 12 - Identidade visual da $4^{\mathrm{a}}$ Conferência Municipal de Juventude ...............142

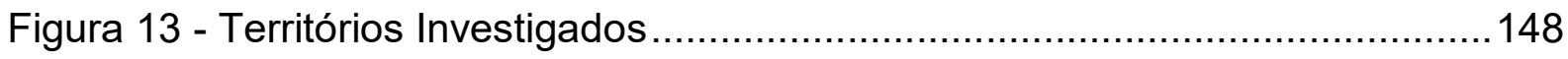

Figura 14 - Sentidos atribuídos ao ser jovem e juventude ................................... 159

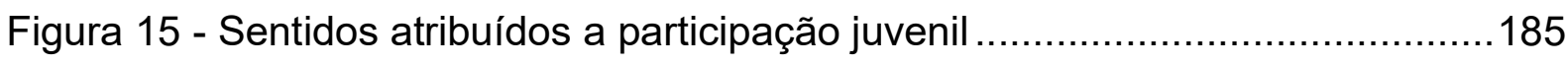

Figura 16 - Sentidos atribuídos as Conferências de juventude .............................206 


\section{LISTA DE QUADROS}

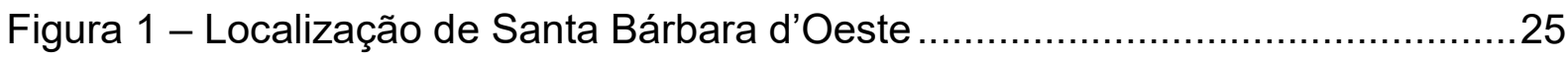

Figura 2 - Esquema das Conferências Típicas......................................................91

Figura 3 - Identidade visual da $1^{\text {a }}$ Conferência Nacional de Juventude .................119

Figura 4 - Identidade visual da $2^{\mathrm{a}}$ Conferência Nacional de Juventude ..................122

Figura 5 - Identidade visual da $3^{\text {a }}$ Conferência Nacional de Juventude .................125

Figura 6 - Show durante a $3^{\text {a }}$ Conferência Nacional de Juventude ........................126

Figura 7 - GT Educação (esquerda) e Momento de abertura da $1^{\text {a }}$ Conferência

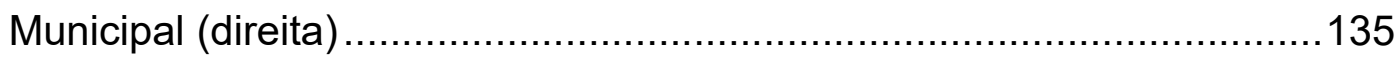

Figura 8 - Identidade visual da $2^{\mathrm{a}}$ Conferência Municipal de Juventude …............137

Figura 9 - Abertura da $2^{\text {a }}$ Conferência Municipal de Juventude ...........................138

Figura 10 - Ciranda durante Conferência Livre realizada pela PJ .........................138

Figura 11 - Identidade visual da $3^{\text {a }}$ Conferência Municipal de Juventude ...............140

Figura 12 - Identidade visual da $4^{\mathrm{a}}$ Conferência Municipal de Juventude ...............142

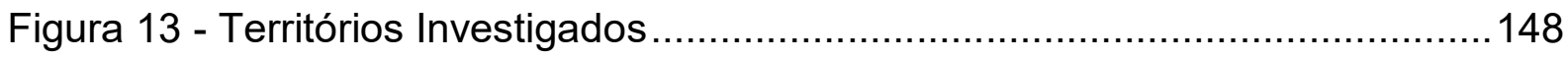

Figura 14 - Sentidos atribuídos ao ser jovem e juventude ...................................159

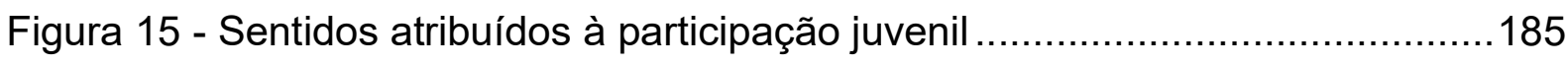

Figura 16 - Sentidos atribuídos às Conferências de juventude .............................206 


\section{LISTA DE TABELAS}

Tabela 1 - Distribuição da população de Santa Bárbara d'Oeste por faixa etária,

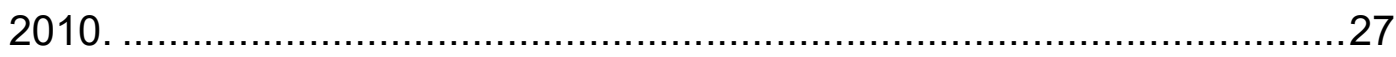

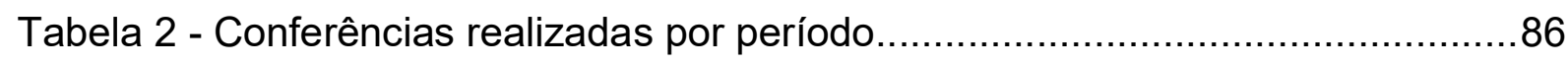

Tabela 3 - Balanço das Conferências Nacionais de Juventude ..............................111

Tabela 4 - População jovem em Santa Bárbara d'Oeste........................................130 


\section{LISTA DE ABREVIATURAS E SIGLAS}

ABRIMPE Associação Brasileira de Incentivo e Projetos Empresariais

AJQV

Grupo de Trabalho A Juventude quer viver

APASB

Associação Pró-Ambiente de Santa Bárbara

ASABZSUL Associação de Amigos dos Bairros da Zona Sul

AVISP Grupo de Adolescente Instruindo Sexualidade e Prevenção

CAIC

Centro de Atenção Integral à Criança e ao Adolescente

CEB'S

Comunidades Eclesial de Bases

CEU

Centro de Artes e Esportes Unificados

CF-88

Constituição Federal de 1988

CNBB

Conferência Nacional dos Bispos do Brasil

COE

Comissão Organizadora Estadual

COM

Comissão Organizadora Municipal

CoMJuv

Conselho Municipal de Juventude

CON

Comissão Organizadora Nacional

ConfJuv

Conferência de Juventude

CONJUVE Conselho Nacional de Juventude

CONSEG Conselho de Segurança

CUT

Central Única dos Trabalhadores

DEM

Democratas

DF

Distrito Federal

DNJ

Dia Nacional de Juventude

DST-AIDS Doenças Sexualmente Transmissíveis - Síndrome de Imunodeficiência Adquirida

ECA Estatuto da Criança e do Adolescente

EJ Estatuto da Juventude

ETEC Escola Técnica

FHC Fernando Henrique Cardoso

GO Goiás

HAB Habitantes

IBGE Instituto Brasileiro de Geografia e Estatística

IPEA Instituto de Pesquisa Econômica Aplicada

IRSSA Instrutores de Referência a Saúde Sexual do Adolescente 


$\begin{array}{ll}\text { JEJU } & \text { Jesus Encontra Jovens Unidos } \\ \text { JPSDB } & \text { Juventude do Partido da Social Democracia Brasileira } \\ \text { JPT } & \text { Juventude do Partido dos Trabalhadores } \\ \text { LGBT } & \text { Lésbicas, gays, bissexuais e transexuais } \\ \text { MCCJ } & \text { Movimento Cultural de Conscientização Juvenil } \\ \text { MPV } & \text { Medida Provisória } \\ \text { OAB } & \text { Ordem dos Advogados do Brasil } \\ \text { PDC } & \text { Projeto de Decreto Legislativo } \\ \text { PDC-SF } & \text { Projeto de Decreto Legislativo - Senado Federal } \\ \text { PDT } & \text { Partido Democrático Trabalhista } \\ \text { PE } & \text { Pernambuco } \\ \text { PEC } & \text { Projeto de Emenda à Constituição } \\ \text { PJ } & \text { Pastoral da Juventude } \\ \text { PNPS } & \text { Política Nacional de Participação Social } \\ \text { PPJ } & \text { Políticas Públicas de Juventude } \\ \text { PSDB } & \text { Partido da Social Democracia Brasileira } \\ \text { PT } & \text { Partido dos Trabalhadores } \\ \text { SBO } & \text { Santa Bárbara d'Oeste } \\ \text { SERPRO } & \text { Serviço Federal de Processamento de Dados } \\ \text { SF } & \text { Senado Federal } \\ \text { SINAJUVE } & \text { Sistema Nacional de Juventude } \\ \text { SNJ } & \text { Secretaria Nacional de Juventude } \\ \text { SNPS } & \text { Sistema Nacional de Participação Social } \\ \text { TCLE } & \text { Termo de Consentimento Livre e Esclarecido }\end{array}$


1-INTRODUÇÃO _ 18

2-JUVENTUDE COMO CONSTRUÇÃO DISCURSIVA __ 30

2.1 - Tessituras sobre sujeito, identidade e diferença______ 32

2.2 - Tessituras da modernidade: o sujeito jovem, a identidade e a diferença__ 41

2.3 - Juventude e contornos territoriais: podem idades dizer quem eu sou? _ 56

3-CONFERÊNCIAS NACIONAIS COMO INSTÂNCIA DE PARTICIPAÇÃO ______ 65

3.1 - Possibilidades participativas: discursividades sobre a participação ___ 66

3.2 - A Política Nacional de Participação Social e o Sistema Nacional de Participação Social 78

3.3 - Conferências Nacionais como forma de participação social: surgimento, recorrência e institucionalização 85

3.4 - Reflexões sobre as conferências nacionais 93

4-PROCEDIMENTOS METODOLÓGICOS 100

4.1 - Voos e pousos sobre os relatórios das conferências e minhas memórias_ 103

4.2 - Entrevistas 104

4.3 - Entrevistados: companheiros (as) de voos e pousos ___ 107

4.4 - Análise das entrevistas - Mapas dialógicos___ 108

5-AS CONFERÊNCIAS NACIONAIS E MUNICIPAIS DE JUVENTUDE _________ 111

5.1 As Conferências Nacionais de Juventude _______ 111

5.1.1 - $1^{\text {a }}$ Conferência Nacional de Juventude: ___ 117

5.1.2 - $2^{\text {a }}$ Conferência Nacional de Juventude: 121

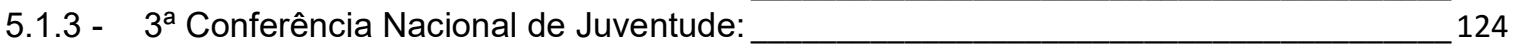

5.2 As Conferências Municipais de Juventude em Santa Bárbara d'Oeste - SP_ 129

5.2.1 - $1^{\text {a }}$ Conferência Municipal de Juventude: Levante sua bandeira __ _ 132

5.2.2 - $\quad 2^{\text {a }}$ Conferência Municipal de Juventude: Conquistar Direitos, desenvolver o Brasil _ 136

5.2.3 - $\quad 3^{a}$ Conferência Municipal de Juventude: Juventude criando espaços de participação 140

5.2.4 - $\quad 4^{\text {a }}$ Conferência Municipal de Juventude: As várias formas de mudar o Brasil __ 142

5.3 - Algumas reflexões a partir destes voos e pousos ___ 144

6-TERRITÓRIOS INVESTIGADOS___ 148

6.1 _ Juventude e Jovem _____ 148

6.1.1 - Juventude e o ser jovem: discursividades a partir de Santa Bárbara d'Oeste ___ 148

6.1.2 - Ser jovem em Santa Bárbara: problematizações sobre o ser jovem no espaço da cidade 160

6.2 - Participação juvenil

6.2.1 - Sentidos da participação juvenil a partir das conferências ___ 171

6.2.2 - Os porquês da Participação juvenil em Santa Bárbara d'Oeste ___ 186

6.3 Conferência ___ 191

6.3.1 - Como ficou sabendo? ___ 191

6.3.2 - Significados e sentidos das conferências __ 195 
APÊNDICE A - MODELO DO TERMO DE CONSENTIMENTO LIVRE E ESCLARECIDO 238

ANEXO A - DECRETO FEDERAL N.9 8243/2014 240

ANEXO B - PDC N.o 1491/2014 245

ANEXO C - PDC-SF N.o 147/2014 249

ANEXO D - CARTILHA PNPS 250

ANEXO E - COMPARATIVO DE CONFERÊNCIAS POR TEMAS E ANOS 252

ANEXO F - ATA DA REUNIÃO DO COMJUV COM AUTORIZAÇÃO AO USO DOS RELATÓRIOS FINAIS 255

ANEXO G - PLATAFORMA BRASIL - PARECER CONSUBSTÂNCIADO 257

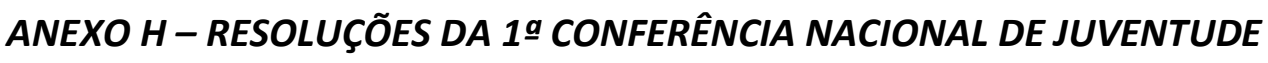
259 ANEXO I - PARA DESENVOLVER O BRASIL ! 262 ANEXO J - RESOLUÇÕES APROVADAS NA 29 CONFERÊNCIA NACIONAL DE JUVENTUDE_ 268 ANEXO K - COMO FUNCIONAM OS GRUPOS DE TRABALHO 3 CONFJUV 277 ANEXO L - RESOLUÇÕES APROVADAS NA 3ㅁONFJUV 279 ANEXO M - RESOLUÇÕES APROVADAS NA 19 CONFERÊNCIA MUNICIPAL DE JUVENTUDE290 ANEXO N - RESOLUÇÕES APROVADAS NA 2ㅁ CONFERÊNCIA MUNICIPAL DE JUVENTUDE 293 ANEXO O - RESOLUÇÕES APROVADAS NA 3ㅍ CONFERÊNCIA MUNICIPAL DE JUVENTUDE 296 ANEXO P - RESOLUÇÕES APROVADAS NA 4a CONFERÊNCIA MUNICIPAL DE JUVENTUDE 299 ANEXO Q - AUTORIZAÇÃO PARA UTILIZAÇÃO DE FOTOGRAFIAS PRESENTE NO SITE DA PREFEITURA 


\section{1- INTRODUÇÃO}

Criadas em 1941, foi a partir de 2003 que as Conferências Nacionais de Juventude tiveram seu ápice. Das 143 conferências nacionais, 102 foram realizadas neste período. Além de um salto quantitativo, foram ampliadas também as temáticas abarcadas neste mecanismo de participação.

Soma-se a isso a criação, em 2007, da Política Nacional de Participação Social (PNPS) que, ao instituir o Sistema Nacional de Participação Social, prevê entre os seus mecanismos de participação a realização de conferências nacionais, consideradas como espaços de diálogo entre a sociedade civil ${ }^{1}$ e o poder público.

Esse processo de realização de conferências não se restringe à esfera federal, e acaba por desencadear em todo país uma série de etapas municipais, estaduais/distritais e territoriais.

A juventude, que tem sido território de diversas construções discursivas em toda a sociedade perpassando pela academia, grupos/coletivos juvenis e estrutura de governo, inclusive como foco de políticas públicas, passa a ser também tema das conferências nacionais. Suas edições acontecem em 2008, 2011 e 2015.

Diante desse cenário, o município de Santa Bárbara d'Oeste se insere realizando etapas preparatórias para a Conferência Nacional de Juventude, em 2008, 2011 e 2015. Em decorrência do movimento criado no tocante às políticas públicas de juventude, o município passa a criar dispositivos jurídicos que preveem espaços de participação destinados ao público jovem, inclusive com previsão de conferências municipais a cada dois anos, o que ocasionou a conferência municipal em 2014.

Este boom discursivo sobre juventude e participação, no qual estava mergulhado como militante, voltou a me instigar enquanto pesquisador. $O$ interesse por juventude iniciou-se a partir da graduação em Geografia, durante as aulas de geopolítica. Dessas aulas, recordo da presença do então assessor de juventude, do município de Rio Claro, que, ao problematizar o que era a assessoria de juventude e o trabalho por ele realizado, me inquietou a pensar isso a partir da cidade que não era minha terra natal, porém era o lugar onde havia passado a minha vida toda. Mais do

1 Para Souza (2006) a sociedade civil, pode ser vista como um conceito neoliberal criado para substituir e relativizar a importância dos movimentos sociais. Este conceito será empregado em virtude da sua adoção nos espaços participativos fonte desta pesquisa. 
que estudar aquele tema, esse momento me interpelou a pensar por que minha cidade não possuía tal espaço, e quais seriam os possíveis caminhos para sua introdução em âmbito municipal.

Anos mais tarde, após o fim da graduação, esse interesse foi interpelado e ampliado pela participação e militância, em grupos e espaços de coordenação da Pastoral da Juventude, que me aproximaram do debate das políticas públicas de juventude e da organização das conferências de juventude no município de Santa Bárbara d'Oeste.

A partir de então, vida acadêmica e militância passaram a se emaranhar, a militância produzia perguntas e inquietações que eram remetidas a perguntas e objetos de estudo na vida acadêmica.

Em 2007, após a conclusão da licenciatura em Geografia, em decorrência da minha vida profissional, fui morar em Santos. Foi nessa ocasião que conheci a Conferência Municipal de Juventude através de uma matéria no diário oficial do município.

Entretanto, minha militância e coração estavam em Santa Bárbara d'Oeste, e uma oportunidade profissional me levou a retornar à cidade no final de 2007. Naquele momento tive a ideia: se existe conferência de juventude em Santos, porque não fazer a conferência municipal de juventude em Santa Bárbara d'Oeste também?

A ideia se transformou em desejo e encontrou terreno fértil com o convite de um amigo, que havia se tornado vereador, para assessorá-lo. Em seguida, acompanhado de um grupo de amigos da Pastoral da Juventude (PJ) de Santa Bárbara d'Oeste, fomos participar da Conferência Municipal de Juventude em Santos, com a intenção de conhecer o que era uma conferência, e oportunizar à juventude de nossa cidade o conhecimento desse espaço, e a partir de então pensar as políticas públicas de juventude em nossa municipalidade.

Sonhamos, acreditamos e realizamos a etapa municipal em Santa Bárbara d'Oeste. Tive o privilégio de ser eleito delegado e participar de todas as etapas até a Conferência Nacional. De forma tímida, como jovem que ainda não dominava totalmente o vocabulário da área e nem sempre sabia do que os outros estavam falando, acompanhava tudo com curiosidade e atenção, com o desejo de replicar e construir tais possibilidades em Santa Bárbara d'Oeste.

Esta vivência deu origem a minha primeira produção acadêmica, quando na graduação fui provocado pelo meu orientador, professor Romualdo Dias, a relatar a 
experiência de organização e participação na $1^{\text {a }}$ Conferência Nacional de Juventude em todas as suas etapas eletivas.

A $1^{\text {a }}$ Conferência Nacional de Juventude possibilitou a mim e a outros jovens de Santa Bárbara d'Oeste nos inserirmos em outros espaços de participação, fomentando o debate das políticas públicas de juventude em nível regional, estadual e nacional, a partir dos desdobramentos produzidos.

Minha trajetória profissional reservou-me um novo voo e pouso na Baixada Santista, agora para trabalhar no Instituto Federal de São Paulo. Nessa estada, pude participar da Conferência Nacional de Educação de 2010, vivenciando esse espaço ao lado de jovens do movimento estudantil.

Em 2011, ano da $2^{\text {a }}$ Conferência Nacional de Juventude, mesmo morando em Santos, atuei nos finais de semana e durante a semana, através das redes sociais, na construção da $2^{a}$ Conferência Municipal de Juventude em Santa Bárbara d'Oeste, ajudando a construir, inclusive, o projeto de lei que criava o Conselho Municipal de Juventude. Novamente participei de todas as etapas, sendo que, desta vez com a Pastoral da Juventude mais articulada, assumi a responsabilidade, no espaço regional e estadual, de articular e participar das negociações políticas para assegurar a participação de nossos delegados na etapa nacional.

No ano seguinte retornei à Santa Bárbara para trabalhar no SESI e, após a criação do Conselho Municipal de Juventude, fui eleito presidente do mesmo (20112014).

A esta altura, o tema conferência e políticas públicas de juventude já me dominava e com ele novos pensamentos e inquietações que novamente reverberaram na vida acadêmica. Na especialização em Gestão Pública, busquei aprofundar o estudo sobre as políticas públicas de juventude no Brasil. A frustração com uma primeira tentativa de ingresso no mestrado em Mudança Social e Participação Política me levou à especialização em Juventude no Mundo Contemporâneo, ofertada pela Rede de Institutos de Juventude. Lá, além de estudar a capacidade inclusiva das conferências de juventude em Santa Bárbara, retomei a coragem e o desejo de fazer o mestrado e romper com o pensamento de que esse espaço da academia não era para mim.

Ao ingressar no mestrado, tive a sorte de encontrar em meu caminho a Professora Doutora Elizabete Franco Cruz, pesquisadora militante, que, ao me apresentar a possibilidade de pensar minhas inquietações militantes a partir de Michel 
Foucault, me provocou a ver o mundo de forma menos binária, com outras possibilidades de compreensão das relações de poder.

Estas provocações reverberaram em minha militância e em meu agir durante a organização da $3^{a}$ Conferência Municipal de Juventude. Ao mesmo tempo provocaram em minha trajetória acadêmica perguntas como: Por que realizam tantas conferências? Se o objetivo é ouvir a sociedade civil, por que, após o findar das conferências, as proposições são esquecidas? Quais as possibilidades que estas conferências têm produzido? Por que muitos jovens não participam e não se inserem nestes espaços? Será que o que é proposto coincide com o que pensam os jovens que não participam?

$\mathrm{Na}$ verdade, ao refletir sobre tais questões, o que me inquietava era, como professor, vislumbrar nas conferências um espaço de formação para a cidadania, que deveria ser incentivado pelo poder público, em especial, através da implementação de políticas públicas de juventude, engendradas a partir das proposições das conferências. Pensava que esta lógica poderia também legitimar o espaço das conferências e incentivar a participação da juventude nos debates, corroborando para ampliar os sentidos e o desejo de sua participação.

Como nunca consegui dissociar a vida acadêmica da pessoal e da militância, até por não acreditar que, como pessoas, sejamos repartidos em várias caixas que não se comunicam e não reverberam entre si, passei nesse processo por algumas mudanças de ordem pessoal. Entre elas, havia superado o limite, estabelecido pelo Estatuto da Juventude, da faixa etária juvenil. E agora 30? Como lidar com isso em minha militância, tendo em vista que passar dos 29 anos, em alguns espaços de políticas públicas de juventude, é como perder a legitimidade para atuar e falar de juventude? Como superar isto em um espaço que vê a juventude como sujeito de direito e protagonista sem que minha presença, em tese, como adulto, não fosse vista como tutela?

Literalmente me via diante do exposto por Deleuze e Parnet:

Os segmentos implicam também dispositivos de poder, bem diversos entre si, cada um fixando o código e o território do segmento correspondente. São dispositivos cuja análise Foucault levou longe, recusando ver neles simples emanações de um aparelho de Estado preexistente. Cada dispositivo de poder é um complexo código-território (não se aproxime de meu território, sou eu quem manda aqui...). (DELEUZE; PARNET, 1998, p.150) 
Nos próprios documentos da Pastoral da Juventude (PJ), o espaço de representação e de atuação é restrito aos jovens (ou pessoas) com até 29 anos. Querer ocupar estes espaços fora dessa idade é visto como querer tutelar os jovens, ou então atrapalhar o protagonismo juvenil. Ter mais de 29 anos é transitar dentro da PJ de um espaço de protagonismo, para o espaço de assessoria. Trata-se aqui do poder simbólico, e de fixação de pessoas em lugares a partir das tecnologias etárias.

Dessa forma, ingressar juridicamente na vida adulta gerava medos que produziam desconforto pelos ditos e interditos produzidos e reverberados sobre o que é autorizado, ou não, a falar e a militar na temática da juventude e também por me reportarem a espaços onde eu não queria estar e por me deslegitimar de espaços nos quais desejava estar.

O tempo necessário para concluir esse mestrado foi me levando a colocar de lado certas demandas e espaços de militância. Ainda que não tivesse abandonado todos, deixei vários, por achar que não fazia sentido ali estar. Mesmo assim, com ajuda do Grupo de Trabalho "A juventude quer viver", da PJ e acima dos 29 anos, fui convidado a representar a Pastoral no espaço da Comissão Organizadora Estadual de São Paulo, e a contribuir na organização da $3^{a}$ Conferência Estadual e na articulação da Pastoral rumo a $3^{a}$ Conferência Nacional de Juventude.

Estar neste território me permitiu novas possibilidades e experiências que contribuíram na pesquisa, considerando que a "experiência pode ser vista como o lugar de uma espera ativa, na medida em que uma utopia vem sendo testada dia a dia”, conforme problematizado por Dias (2002, p.14).

Neste processo, fui levado a refletir sobre os imbricares das relações de poder e as maquinarias que atuam no espaço das conferências, desencadeando conjecturas sobre as minhas práticas e construções discursivas nas etapas municipais e nacionais.

A experiência adquirida como organizador de três Conferências Municipais e como participante de duas Conferências Nacionais de Juventude e uma Conferência Nacional de Educação me permitiu agir com cautela ao tomar decisões e posicionamentos dentro da Comissão Organizadora Estadual. Nesse período, pude fazer novas reflexões sobre as formas de subjetivação da juventude e da participação juvenil e as relações de poder que permeavam as relações entre grupos/coletivos e jovens nesse espaço, concebendo o poder diante do apresentado por Foucault (2014, 
p.242) como algo que "não é simplesmente uma relação entre 'parceiros' individuais ou coletivos; é um modo de ação de alguns sobre outros".

Esse movimento, associado às leituras do mestrado, em especial Foucault, e as reflexões ao longo dos encontros do grupo de pesquisa em Gênero, Educação e Saúde Coletiva, serviram para amadurecer e questionar a concepção de juventude, e também o espaço, os lugares de onde eu falava. Estas percepções me ajudaram a olhar as coisas, os espaços e o mundo de outras formas. Como diz Veiga-Neto (1996, p.19), "tudo indica que deveremos sair dessas bases para, de fora, examiná-las e criticá-las". Por vezes, achando que não concluiria o mestrado, mergulhei nestes caminhos desafiadores em movimentos que não foram feitos com facilidade, tampouco de maneira confortável. Deixando de relutar, decidi me aventurar por novos voos e pousos.

Durante esta pesquisa, a todo tempo era desafiado a fazer e olhar de outro modo para a juventude, para as conferências e para a concepção de participação que eu tinha. Deixar verdades pré-estabelecidas construídas ao longo de outras pesquisas e também durante a militância e vida enquanto jovem. Ou, como afirma Veiga-Neto (p.19), "desconfiar das bases sobre as quais se assentavam as promessas e as esperanças nas quais nos ensinaram acreditar". Foi necessário questionar essas verdades, foi necessário sair da zona de conforto e me arriscar para conhecer novos territórios.

Nessa trajetória, a mim foi apresentado o pós-estruturalismo que parte da concepção que:

As imagens que o mundo, principalmente social, nos apresenta, a rigor, ele não nos apresenta isentamente, isso é o olhar que botamos sobre as coisas que, de certa maneira, as constitui. São os olhares que colocamos sobre as coisas que criam os problemas do mundo. Em outras palavras, não há problemas em si. (VEIGA-NETO, 1996, p.27)

Com o pós-estruturalismo, internamente vi ocorrer uma implosão, como proposto por Groppo (2015a, p.568), em que os edifícios que implodiram foram "a estrutura social moderna, o eixo paradigmático da sociologia clássica e a estrutura moderna das categorias etárias".

Juntamente com Foucault, passei a revisitar textos de Deleuze, Guattari e Sueli Rolnik e a retomar, de outra maneira, um conceito muito utilizado na geografia, 0 conceito de território. Para Deleuze e Guattari (1997, p.105), território é visto como "um ato, que afeta os meios e os ritmos, que os 'territorializa'”. E ainda, "território é o 
produto de uma territorialização dos meios e dos ritmos". Silva (2000) explica também que esses autores, ao falarem de territorialização, remetem a codificar, a submeter a regras e controles, setores ou elementos da vida social, como, por exemplo, a família, o trabalho, o corpo.

Com a ideia de território, busquei conhecer a cartografia como método de pesquisa e ousar pensar como um aprendiz de cartógrafo, realizando neste percurso voos e pousos sobre temas que perpassariam minha pesquisa.

Utilizei a cartografia por acreditar que ela me possibilitaria "mapear os estilos que se criam, as misturas que se insinuam, as linhas de subjetivação que atuam e os dispositivos de poder-saber que se impõem, inúmeras fontes que riscam um dado território da vida social" (GROPPO, 2015a, p.572).

A partir dessa proposta metodológica e das entrevistas realizadas, após o uso dos mapas dialógicos, resolvi pensar as conferências, a juventude e o jovem e a participação juvenil como territórios a serem investigados através de voos e pousos.

Abriu-se um leque de possibilidades, que me ajudaram a compreender as juventudes e as conferências de uma nova forma, sem o objetivo de criar verdades, ou novos binarismos sobre o que vem a ser jovem, juventude e suas formas de participação nas conferências.

Foi preciso compreender que "os enunciados fazem mais do que uma representação do mundo; eles produzem o mundo" (VEIGA-NETO, 1996, p. 28). Busquei aqui perceber não a realidade, mas os sentidos que damos à juventude, ao jovem e às conferências, os enunciados que construímos e algumas alternativas e possibilidades de reflexão acerca destes temas e dos objetivos de minha pesquisa.

Dessa forma, iniciei minha cartografia buscando os sentidos das conferências e das políticas públicas. Porém, ao entrar em contato com a literatura, e com o uso das técnicas desta pesquisa, entre elas as entrevistas e o mapa dialógico, partindo das reflexões por elas provocadas, optei por focar e problematizar os sentidos atribuídos às conferências, ao ser jovem/juventude e à participação juvenil, a partir das Conferências Municipais de Juventude em Santa Bárbara d'Oeste.

A escolha por Santa Bárbara d'Oeste está relacionada a minha trajetória de militante, organizador e participante das Conferências Municipais de Juventude, que foram o território disparador da pesquisa. 


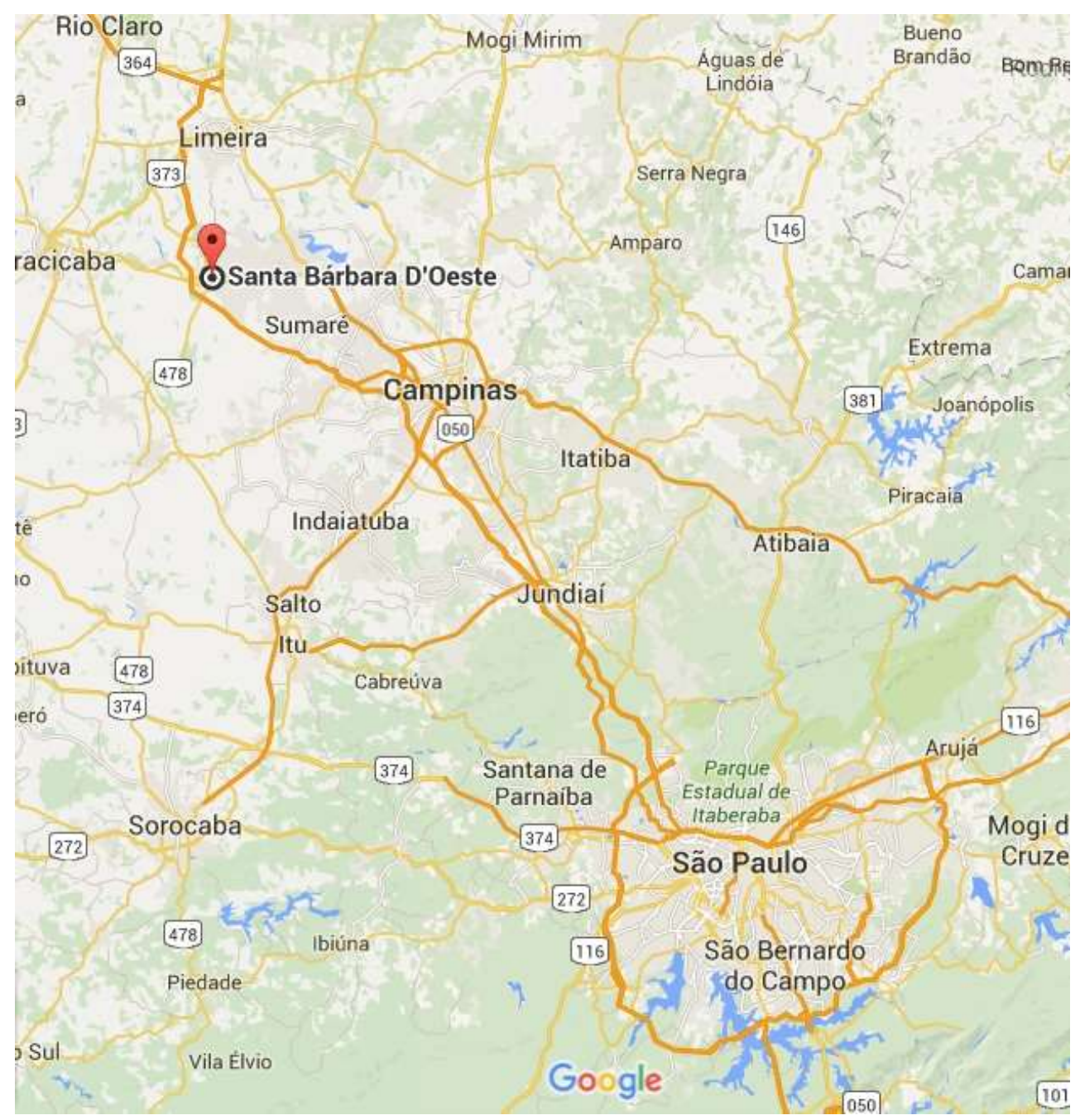

Figura 1 - Localização de Santa Bárbara d'Oeste

Localizada a 135 quilômetros da capital paulista, Santa Bárbara d'Oeste compõe a Região Metropolitana de Campinas. Com área de 270.899 quilômetros quadrados, é cortada pela rodovia dos Bandeirantes (SP-348), Rodovia Dona Margarida Graça Martins (SP-135) e Rodovia Luiz de Queirós (SP-304), Luís Ometto (SP-306), Estrada de Cillos e Rodovia Comendador Emílio Romi (SP-306). O município faz limite a leste com Americana, Nova Odessa e Sumaré; ao sul com Monte-Mor; oeste com Rio das Pedras e Piracicaba e ao norte com Limeira.

Sua fundação remete ao ano de 1818, por Dona Margarida da Graça Martins, oriunda de Santos, que assim nomeou o município por ser devota de Santa Bárbara.

A história do município está associada à Guerra de Secessão nos Estados Unidos (1861-1865). O município, por sugestão de Dom Pedro II, foi ponto de imigração de confederados estadunidenses. Sua presença é marca da cidade até hoje, em virtude do Cemitério do Campo, que concentra as festas anuais das famílias 
de imigrantes, bem como através da presença do Museu da Imigração, que registra a história daquele período de imigração.

O município, inicialmente nomeado Santa Bárbara d'Oeste, foi posteriormente denominado Canatiba, expressão tupi cujo significado é "cana em abundância". A mudança ocorreu como tentativa de evitar a semelhança de nome com cidade existente no interior paulista (Santa Bárbara do Rio Pardo). Porém, como esta nomeação não obteve aceitação, liderados pelo Monsenhor Henrique Nicopelli, os moradores se mobilizaram para o retorno do nome anterior, o que também não foi aceito pelos setores responsáveis. Foi possível resgatar esse fato por meio da página História, do site da Fundação Romi, que o reproduz conforme reportagem publicada no jornal O Diário, em 04/ 02/ 2003:

Formou-se na cidade, em seguida, uma Comissão Especial para defender a não mudança do nome para Canatiba e apenas que se acrescentasse Paulista a Santa Bárbara. [...] A Comissão Especial levou ao Interventor um memorial contendo cerca de duas mil assinaturas de barbarenses solicitando a não mudança do nome da cidade, embora com a concordância em se acrescentar o Paulista a Santa Bárbara, como forma de diferenciação de outras cidades com o nome da Santa Bárbara, como se verificava em alguns Estados do Brasil, como os de Minas Gerais, Bahia, Goiás, Pará, Rio Grande do Sul e até mesmo no de São Paulo, com a existência de Santa Bárbara do Rio Pardo (atual Águas de Santa Bárbara).[...]

Embora com suas terras situadas num município da região leste do Estado de São Paulo, Santa Bárbara teve o d'Oeste acrescentado em sua denominação definitiva por estar, geograficamente no mapa do Brasil e do estado paulista, no rumo oeste, partindo-se tanto da então capital federal, a cidade do Rio de Janeiro, como da capital paulista, a cidade de São Paulo. (FUNDAÇÃO ROMI, 2003)

Além de imigrantes confederados, o município foi ponto de imigração italiana, no século $X I X$, e no século $X X$ tornou-se receptor de migrantes oriundos de outros municípios paulistas ${ }^{2}$, servindo de dormitório para trabalhadores que migravam para trabalhar no Polo Têxtil ${ }^{3}$ que teve Americana como polo central desta atividade econômica, durante a desconcentração industrial em São Paulo.

Ainda que atividades econômicas como o plantio, a colheita da cana-de-açúcar, as indústrias nas áreas de metal mecânica, têxtil e confecções tenham destaque, é o setor terciário o responsável por considerável parte da geração de empregos. A

\footnotetext{
2 Jales, Tupi-Paulista, Dracena, e de cidades localizadas na Região Metropolitana de São Paulo. Hoje o município conta inclusive com o memorial do migrante, Praça com as bandeiras dos municípios oriundos dos migrantes neste período.
}

${ }^{3}$ O Polo Têxtil reúne os municípios paulistas de Americana, Nova Odessa, Sumaré e Santa Bárbara d'Oeste 
Avenida Santa Bárbara, área de conurbação com Americana, é o principal corredor onde estão instalados shoppings centers e redes de supermercado atacadistas. Entre os fatos marcantes da história do município, remeto à década de 1950, quando as Indústrias Romi fabricaram o primeiro veículo em série produzido no Brasil.

Em termos populacionais, de acordo com o censo realizado pelo IBGE em 2010, a população contava com 180.009 habitantes $^{4}$, estando assim distribuída por faixa etária:

Tabela 1 - Distribuição da população de Santa Bárbara d'Oeste por faixa etária, 2010.

\begin{tabular}{|c|c|c|c|c|}
\hline Faixa etária & $\begin{array}{c}\text { Homens } \\
\text { (hab.) }\end{array}$ & $\begin{array}{c}\text { Mulheres } \\
\text { (hab.) }\end{array}$ & $\begin{array}{c}\text { Total de } \\
\text { habitantes }\end{array}$ & $\begin{array}{c}\text { \% da } \\
\text { população }\end{array}$ \\
\hline 0-14 anos & 18.070 & 17.028 & 35.098 & $19,5 \%$ \\
\hline 15-29 anos & 24.576 & 23.896 & 48.472 & $26,9 \%$ \\
\hline 30-64 anos & 40.987 & 42.553 & 83.539 & $46,4 \%$ \\
\hline Mais de 64 anos & 5.589 & 7.310 & 12.899 & $7,2 \%$ \\
\hline
\end{tabular}

Fonte: IBGE, 2010.

A população é em sua maioria cristã, pois, segundo o IBGE (2010), os católicos correspondem a $62,23 \%$ e os evangélicos a $28,7 \%$.

Contextualizar as distribuições da população em aspectos religiosos faz sentido por entender que é a partir de um movimento juvenil religioso que as conferências passam a ser pensadas no município, bem como por ser o território que me engendrou a voar e pousar nas conferências de Juventude.

Por isso, além das narrativas produzidas a partir das entrevistas com participantes e organizadores das conferências e dos relatórios finais nelas produzidos, após hesitação, resolvi recorrer as minhas memórias.

Este hesitar em usar minha experiência de vida e de militância, ainda mais em uma dissertação de mestrado, foi superado nas reuniões do grupo de pesquisa e nas reuniões de orientação, que, a partir da cartografia, me desafiaram a arriscar e utilizálas, neste percurso de voos e pousos, repleto de decolagens e aterrissagens, por novos e velhos territórios, que se desterritorializam e se reterritorializam. Assim:

Esses relatos não se baseiam em opiniões, interpretações ou análises
objetivas, mas buscam, sobretudo, captar e descrever aquilo que se dá no
plano intensivo das forças e dos afetos... Por esse motivo, a escrita do relato
não deve ser um mero registro de informações que se julgam importantes.
Longe de ser um momento burocrático, sua elaboração requer até mesmo
um certo recolhimento, cujo objetivo é possibilitar um retorno a experiência
do campo, para que possa então falar de dentro. (BARROS e KASTRUP,
2015, p.70-71, grifo meu)

${ }^{4}$ Segundo estimativa do IBGE para o ano de 2015, o município contará com 190.139 habitantes. 
Como aprendiz de cartógrafo, passei a utilizar minhas memórias, querendo mergulhar "nas intensidades do presente para dar língua para afetos que pedem passagem" (ROLNIK apud BARROS e KASTRUP, 2015, p. 57-58) ${ }^{5}$. Tais afetos e a temática estudada me levaram a voar e contribuíram para rever os dispositivos que atuaram na construção de minha subjetividade.

A partir daí organizei meus voos e pousos por caminhos nômades, entendidos por Takeuti (2012a, p.7) como "antes de tudo, um modo de pensamento e de agir por deslocamentos em linhas de fuga e pela descodificação em direção à reinvenção de um novo corpo". Saliento, porém, que, trilhando tais caminhos, os voos e pousos não implicaram deslocamentos espaciais, considerando, como o referido autor, que "existem viagens num mesmo lugar, viagens em intensidade" ( $p .17)$.

Apresento neste trabalho o caminho que trilhei e as considerações, sempre provisórias, que pude fazer sobre os temas que me dediquei a pesquisar.

No Capítulo 2 iniciarei as problematizações e debates a partir de autores como Goulart (2011), Cruz (2005), Ariès (1981), Levi e Schmitt (1996), Veiga-Neto (2000; 2014), Larrosa (1994), Cunha (2014), Takeuti (2012a), Silva (2010), Silva (2011), Groppo (2000; 2013; 2015), Woodward (2007), Ferre (2011), César (1998), Campos (2008), Frezza (2009), Debert (2010), Kehl (2004), Coimbra, Bocco e Nascimento (2005). A partir das reflexões engendradas, busco compreender a juventude enquanto uma construção discursiva da sociedade moderna, que na atualidade recebe diversos contornos discursivos, que perpassam e são produzidos a partir de tecnologias do eu presentes nos processos de subjetivação que reverberam em subjetividades juvenis. Saliento, porém, que "não nos interessa aqui assumir uma dessas posições, muitas vezes contraditórias, especialmente porque parecem conferir a juventude uma determinada natureza ou essência de um lado, potência, e de outro, problema" (FREZZA; MARASCHIN; SANTOS, 2009, p.314).

No Capítulo 3, problematizarei as concepções e sentidos da participação, buscando compreender como eles contribuem na produção de subjetividades e populações. Ainda nesse capítulo apresento e problematizo algumas dimensões da Política Nacional de Participação Social (PNPS) e a institucionalização das conferências nacionais buscando possibilidades e potencialidades de participação rizomática neste espaço estriado. Tal debate é alicerçado por uma série de autores,

${ }^{5}$ ROLNIK, S. Cartografia Sentimental. Porto Alegre: Sulina, 2007. 
entre eles Boghossian e Minayo (2009), Cortes (1998; 2002; 2012), Bordenave (1994), Dias (2002), Gallo (2000), Leon, Dolejsiová e Falangola (2009), Guizardi (2004; 2008; 2009; 2014), Souza (2006), Valadares (2011), Quintanilha e Dalbello-Araujo (2014), Nespoli (2014), Avritzer (2009; 2012), Petinelli (2011), Souza et al.. (2013) e Progrebinschi et al. (2010).

No capítulo seguinte, alinhavo com mais detalhes a metodologia utilizada na pesquisa, apresentando os métodos e as técnicas que me permitiram construir no Capítulo 5 um registro histórico das conferências de juventude, a partir dos relatórios das conferências e da minha vivência, como participante das etapas nacionais e organizador das etapas municipais. No Capítulo 6, apresento a análise das narrativas produzidas nas entrevistas, os sentidos atribuídos à conferência, participação e ao ser jovem/juventude. Os capítulos 5 e 6 se constituem, desta forma, como o resultado produzido a partir da análise.

Para tais construções penso a resistência e a rebeldia, a partir do devir conforme exposto por Deleuze (1992, p.211):

\footnotetext{
Mas não param de misturar duas coisas, o futuro das revoluções na história e o devir revolucionário das pessoas. Nem sequer são as mesmas pessoas nos dois lados. A única oportunidade dos homens está no devir revolucionário, o único que pode conjurar a vergonha ou responder ao intolerável.
}

Minha expectativa é que os voos e pousos, nas Conferências Municipais de Juventude de Santa Bárbara d'Oeste, possibilitem e despertem em outros jovens, pesquisadores e militantes, oportunidades e alternativas de devir criativo. $\mathrm{O}$ devir criativo, que vislumbro na canção $O$ sal da terra, de Beto Guedes, que inspira rebeldia, ousadia, teimosia e inventividade, ao construir as relações de poder, e ao pensar a juventude e as formas de participação. 


\section{2- JUVENTUDE COMO CONSTRUÇÃO DISCURSIVA}

Neste capítulo, problematizarei a conceituação de juventude retomando a leitura de autores que debatem a temática juvenil no Brasil.

Uma vez que os jovens são participantes desta pesquisa, considerei pertinente apresentar algumas discursividades ${ }^{6}$ produzidas sobre o jovem e a juventude.

De início destaco que os conceitos de adolescente e de jovem ou de juventude e adolescência se entrelaçam há muito tempo, conforme menciona Ariès (1981, p.176):

De fato, ainda não se sentia a necessidade de distinguir a segunda infância, além dos 12 ou 13 anos, da adolescência e da juventude. Essas duas categorias de idade ainda continuam a ser confundidas. Elas só se separariam mais para o fim do século XIX, graças à difusão, entre a burguesia, de um ensino superior, universidade ou grandes escolas.

Apesar do realçado por Ariès, evidencio também que, nesta pesquisa, o enfoque central não está na construção do conceito de adolescência e adolescente, mesmo compreendendo que se trata de palavras privilegiadas em áreas tais como a psicologia, a pedagogia e a medicina.

Para trilhar este caminho, retomo conceitos como o de sujeito, identidade, diferença, discurso e dispositivos, presentes nos estudos desenvolvidos por Foucault, Deleuze, Guatari e Rolnik. Destaco que minha escolha por eles se deve a circunstância de, assim como Larrosa (1994, não paginado), pressupor que eles "são selecionados porque 'dão o que pensar', porque permitem 'pensar de outro modo', explorar novos sentidos, ensaiar novas metáforas".

Recorro também a autores como Aguiar (2007), Campos (2008), Cesar (1998), Cruz (2005), Silva (2011) por considerar a relevância dos estudos por eles desenvolvidos e ao problematizado sobre os conceitos de adolescência e o adolescente como construções discursivas, problematização que desejo realizar com os conceitos de jovem e juventude.

Em consonância ao dito por Jorge Larrosa, em Tecnologias do eu e a educação, esta não será uma pesquisa sobre arqueologia dos jovens e da juventude.

6 Discursividades deriva de discurso que compreendo como responsáveis pela definição das subjetividades. Segundo Foucault (2014, p. 10), "não é simplesmente aquilo que manifesta (ou oculta) o desejo; é também aquilo que é o objeto do desejo; e visto que - isto a história não cessa de nos ensinar - o discurso não é simplesmente aquilo que traduz as lutas ou os sistemas de dominação, mas aquilo por que, pelo que se luta, o poder do qual nos queremos apoderar". 
"Tampouco é um trabalho de historiador, de psicólogo, de filósofo ou de um sociólogo" (LARROSA, 1994, não paginado). Diferente do que fiz em outros escritos ${ }^{7}$, hoje perseguirei forma menos binária, dialogando com os autores mencionados, que aqui foram meus interlocutores para problematizar as construções discursivas acerca da juventude e do jovem, construídas nas relações de poder e que partem da necessidade da sociedade burguesa em disciplinar e classificar os indivíduos.

Trilhar estas novas trajetórias só foi possível, como diz Cunha (2014) ao interpretar Deleuze (2000), após um encontro com aquilo que força a pensar, associado ao desejo de trilhar um pensamento nômade, compreendido como "aquele onde não importa os pontos de chegada ou de partida, mas sim os trajetos que percorre", e "que surge do encontro com o impensável, com o imprevisto, sem que esteja remetido a uma experiência vivida ou representada, mas é conduzido apenas pela criação, pelo advento do novo" (CUNHA, 2014, p.59).

Como convidado por Rolnik (1997a), buscarei nesta trajetória nômade manter o olho vibrátil ${ }^{8}$ para "dar uma reviravolta na história, desconectando-a do rolo compressor dialético ${ }^{9}$ da busca por universalidade" (GOULART, 2011, p.15).

Neste capítulo, tecerei os conceitos de sujeito, diferença e identidade, que penso serem pertinentes para compreender a reconstrução discursiva sobre juventude na sociedade burguesa, enfocando contornos discursivos recorrentes acerca dos jovens e da juventude na atualidade.

\footnotetext{
7 Refiro-me às pesquisas realizadas durante a graduação em Geografia (UNESP- Rio Claro) "Implementação e Gestão de Políticas de/para/com as Juventudes: propostas para o município de Santa Bárbara d'Oeste - São Paulo" e durante as especializações, em Gestão Pública (UFSM), "Políticas Públicas de Juventude: propostas da UNESCO e do Governo Federal versus demandas juvenis" e "A capacidade inclusiva das conferências de juventude em Santa Bárbara d'Oeste - SP", desenvolvida durante a especialização em Juventude (PUC-GO).

${ }^{8}$ Vibrátil, segundo Rolnik (1997a, p. 25), é o que faz com que o olho seja tocado pela força do que vê.

${ }^{9}$ Dialético, segundo Silva (2000), é termo atribuído ao processo de desdobramento das contradições internas da sociedade capitalista, que a transformam, quantitativa e qualitativamente, em uma outra coisa. "O método dialético é aquele que toma em consideração a natureza dialética dos movimentos que constituem estas transformações"(p.40).
} 


\section{1 - Tessituras sobre sujeito, identidade e diferença}

Para compreender a juventude enquanto construção discursiva, considero pertinente analisar primeiro como os jovens são transformados em sujeitos. Para tanto, neste tópico abordarei os conceitos de sujeito, identidade e diferença.

A respeito da concepção de juventude e adolescência no pós-estruturalismo, Cruz (2005) descreve bem como adolescência e juventude são concebidas nesta teoria, e a análise de Áries (1981), Levi \& Schmiitt (1996), Kuhlmann Jr \& Fernandes (2004) apontam também a variação discursiva destes conceitos ao longo do tempo:

O conceito de adolescência, tal qual o conceito de infância, também foi construído historicamente, num conjunto de procedimentos discursivos que Ihe conferiu o caráter de verdade. Ao longo da história, observou-se que a nomenclatura associada a diferentes idades foi variando e adquirindo diferentes significações, ou seja, nem sempre as nomenclaturas infância, adolescência e juventude corresponderam às mesmas faixas etárias e características que imaginamos hoje. (CRUZ, 2005, p.143)

Sobre o sujeito, produto da modernidade, Foucault problematiza sua construção e significados, a partir das relações de poder:

Essa forma de poder aplica-se à vida cotidiana imediata que categoriza o indivíduo, marca-o com sua própria individualidade, liga-o à sua própria identidade, impõe-Ihe uma lei de verdade, que devemos reconhecer e que os outros têm que reconhecer nele. É uma forma de poder que faz dos indivíduos sujeitos. Há dois significados para a palavra sujeito: sujeito a alguém pelo controle e dependência, e preso à sua própria identidade por uma consciência ou autoconhecimento. Ambos sugerem uma forma de poder que subjuga e torna sujeito a. (FOUCAULT, 1995, p.235)

Ao tematizar a construção do sujeito na mesma vertente de Foucault, Veiga Neto (2014, p.108) destaca a significação do sujeito em teorias que apresentam pensamento diferente do pós-estruturalismo:

Uma entidade já dada, uma propriedade da condição humana, e por isso, desde sempre aí, presente no mundo. A própria noção moderna de que o sujeito é a matéria-prima a ser trabalhada pela Educação - seja para levá-lo de um estado selvagem para um estado civilizado (como pensou Rousseau), seja para levá-lo da menoridade para a maioridade (como pensaram Kant, Hegel e Marx) - partiu do entendimento de que o sujeito é uma entidade natural e, assim, preexistente ao mundo social, político, cultural e econômico.

Na concepção pós-estruturalista, o sujeito não é "dado", e não está posto aí desde sempre. Aceitar a naturalização do sujeito, como apresentado nestas teorias, é negar a sua construção como sujeito por uma série de dispositivos presentes em nosso cotidiano, e que agem por meio das relações de poder. 
Considerar que toda relação social é uma relação de poder é constatar a inexistência de sociedades sem relações de poder, uma vez que uma sociedade "sem relações de poder' só pode ser uma abstração" (Foucault, 1995, 245-246).

Complementando o teorizado por Foucault sobre a construção do sujeito, Guattari e Rolnik (1996, p. 25) também questionam sua suposta naturalidade:

O sujeito, segundo toda uma tradição da filosofia e das ciências humanas, é algo que encontramos como um "etre-la", algo do domínio de uma suposta natureza humana. Proponho, ao contrário, a idéia de uma subjetividade de natureza industrial, maquínica, ou seja, essencialmente fabricada, modelada, recebida e consumida [...] Esquematicamente falando, eu diria que, assim como se fabrica leite em forma de leite condensado, com todas as moléculas que Ihe são acrescentadas, injeta-se representações nas mães, nas crianças - como parte do processo de produção subjetiva.

Sobre a metodologia de análise da construção deste sujeito, Veiga-Neto problematiza que:

É preciso, ao contrário, tomá-lo de fora. Dito de outra maneira, uma analítica
do sujeito, seja qual for a adjetivação que se atribua a esse sujeito -
pedagógico, epistêmico, econômico [incluo aqui os jovens], não pode partir
do próprio sujeito. É preciso, então, tentar cercá-lo e examinar as camadas
que o envolvem e que o constituem. Tais camadas são as muitas práticas
discursivas e não discursivas, os variados saberes, que, uma vez descritos e
problematizados, poderão revelar quem é esse sujeito, como ele chegou a
ser o que dizemos que ele é e como se engendrou historicamente tudo isso
que dizemos dele (2014, p.112 [grifo meu]).

As relações de poder delineadas na construção do sujeito intercorrem a partir de uma série de dispositivos que agem na contemporaneidade em uma sociedade que não é mais disciplinar, mas de controle, uma vez que já não funciona mais por confinamento, mas sim por controle contínuo, utilizando a comunicação instantânea para, através da individualidade, da interioridade e da subjetividade, forjar o sujeito com base nos processos de subjetivação (DELEUZE, 1992; 2005).

Sobre os dispositivos que transformam o indivíduo em sujeito e produzem subjetividades concordo que:

O indivíduo, a meu ver, está na encruzilhada de múltiplos componentes de subjetividade. Entre esses componentes alguns são inconscientes. Outros são mais do domínio do corpo, território no qual nos sentimos bem. Outros são mais do domínio daquilo que os sociólogos americanos chamam de "grupos primários" (o clã, o bando, a turma, etc.). Outros ainda são do domínio da produção de poder: situam-se em relação à lei, à polícia, etc. Minha hipótese é que existe também uma subjetividade ainda mais ampla: é o que chamo de subjetividade capitalística (GUATTARI e ROLNIK, 1996, p.34). 
Tais dispositivos criam, forjam, nomeiam, definem, caracterizam e diferenciam os sujeitos existentes através das múltiplas relações de poder e das diversas formas de governamentos engendradas nessas relações.

Aqueles que escapam a essa lógica são patologizados e classificados como sujeitos anormais, categorizados segundo Foucault em três elementos: o monstro, o indivíduo a corrigir e o masturbador (onanista). Sua criação servirá de base para a efetivação de uma série de dispositivos que interferem no processo de subjetivação e formação das subjetividades. Foucault (1997, p.66) descreve a estruturação deste processo:

A construção de uma teoria geral da "degenerescência" que, a partir do livro de Morel (1857), vai servir, durante mais de meio século, de quadro teórico, ao mesmo tempo que de justificação social e moral a todas as técnicas de localização, de classificação e de intervenção sobre os anormais; a organização de uma rede institucional complexa, que serve, nos confins da medicina e da justiça, ao mesmo tempo de estrutura de "acolhimento" para os anormais e de instrumento de "defesa" da sociedade; enfim, o movimento através do qual o elemento que apareceu mais recentemente na história (o problema da sexualidade infantil) recobrirá os dois outros para se tornar, no século XX, o princípio de explicação mais fecundo de todas as anomalias.

Para melhor compreender quem são estes sujeitos classificados como anormais, por Foucault, recorro novamente a Veiga-Neto (2011, p. 105): Para designar esses cada vez mais variados e numerosos grupos que a
Modernidade vem, incansavelmente e incessantemente, inventando e
multiplicando: os sindrômicos, deficientes, monstros e psicopatas (em todas
suas variadas tipologias), os surdos, os cegos, os aleijados, os rebeldes, os
pouco inteligentes, os estranhos, os GLS, os "outros", os miseráveis, o refugo
enfim.

Para Guattari e Rolnik (1996, p.42), os sujeitos que escapam à produção de subjetividades capitalísticas são incluídos em uma lógica de infantilização, em que "tudo o que se faz, se pensa ou se possa vir a fazer ou pensar seja mediado pelo Estado". Esta mediação baseia-se em dispositivos, os quais entendo, segundo SILVA (2000, p.43), como o "conjunto das práticas, discursivas e não discursivas, consideradas em sua conexão com as relações de poder".

São exemplos de dispositivos, as leis, a escola, os hospitais, as famílias e outras instituições utilizadas neste processo de produção de sujeitos e subjetividades e que acabam por pensar e organizar por nós a produção e a vida social (SILVA, 2000; GUATTARI e ROLNIK, 1996). 
Esse processo de construção dos sujeitos, Deleuze nomeia de processos de subjetivação que podem ser compreendidos como:

As diversas maneiras pelas quais os indivíduos ou as coletividades se constituem como sujeitos: tais processos só valem na medida em que, quando acontecem, escapam tanto aos saberes constituídos como aos poderes dominantes. (1992, p.217)

Trata-se na sociedade pós-moderna do processo produtivo mais importante, conforme dito por Guattari e Rolnik (1996, p.26) "talvez mais importante do que qualquer outro tipo de produção, mais essencial até do que o petróleo e as energias". Tal importância se deve ao fato de que o controle das subjetividades influencia diretamente no processo produtivo, em especial em sua eficiência e eficácia, pois quanto mais disciplinados e menos anormais forem os sujeitos, em tese, mais produtiva será a sociedade, como se observa na defesa feita por esses autores no trecho a seguir:

Quando uma potência como os EUA quer implantar suas possibilidades de expansão econômica num país do Terceiro Mundo, ela começa, antes de mais nada, a trabalhar os processos de subjetivação. Sem um trabalho de formação prévia das forças produtivas e das forças de consumo, sem um trabalho de todos os meios de semiotização econômica, comercial, industrial, as realidades sociais locais não poderão ser controladas. (p.28)

As máquinas ganham uma importância cada vez maior nos processos de produção. As relações de inteligência, de controle e de organização social estão cada vez mais adjacentes aos processos maquínicos; é através dessa produção de subjetividade capitalística que as classes e castas que detêm o poder nas sociedades industriais tendem a assegurar um controle cada vez mais despótico sobre os sistemas de produção e da vida social. (p.39)

Neste processo de subjetivação, merece destaque o conceito de tecnologias do eu. Para explicá-las, autores como Larrosa (1994), Cunha (2014), Takeuti (2012a), Antoun (1992), Rolnik (1997a), Silva (2004) recorrem ao conceito de dobra sistematizado por Deleuze (2005). Com auxílio desses autores, compreendo dobra como,

uma importante ferramenta teórica para se pensar a experiência subjetiva contemporânea. A dobra exprime tanto um território, ou seja, ela exprime o próprio caráter coextensivo do dentro e do fora. A dobra constitui assim tanto a subjetividade, enquanto território existencial, quanto à subjetivação, entendida aqui como o processo pelo qual se produzem determinados territórios existenciais em uma formação histórica específica. A idéia de indivíduo, por exemplo, enquanto território subjetivo moderno, expressa um modo de subjetivação específico, pois traduz uma certa captura da subjetividade dentro de um determinado sistema de códigos, no caso, o sistema de códigos próprio ao modo de produção capitalista. O "modoindivíduo" do capitalismo moderno é completamente diferente da experiência 
subjetiva em outros períodos históricos. A subjetivação refere-se, portanto, às diferentes formas de produção da subjetividade em uma determinada formação social. (SILVA, 2004, p.56)

Para propor o conceito de dobra, Deleuze (2005, p. 105) utiliza autores como Roussel, Gabriel Tarde, Dreyfus e Rabinow e o conceito de duplo de Foucault, visto por Deleuze como "uma obsessão constante de Foucault". A dobra diz respeito ao processo de subjetivação que produz sujeitos e subjetividades:

Com o conceito de dobra, Deleuze busca evitar a referência a qualquer noção de interioridade, de subjetividade prévia ou de sujeito estável, evitando, ao mesmo tempo, qualquer dicotomia ou separação entre interior e exterior, entre "fora" e "dentro". (SILVA, 2000, p.45)

A partir de Deleuze, Larrosa (1994), Cunha (2014), Takeuti (2012a), Antoun (1992), Rolnik (1997 a), Silva (2004 e 2000), observo que o conceito de dobra não pode ser compreendido apartado dos conceitos de subjetivação, subjetividade e identidade:

A dobra parece então ser desdobrada, a subjetivação do homem livre se transforma em sujeição; por um lado é "a submissão ao outro pelo controle e pela dependência", com todos os procedimentos de individualização e de modulação que o poder instaura atingindo a vida quotidiana e a interioridade daqueles que ele chamara seus sujeitos; por outro lado, é o "apego (de cada um) à sua própria identidade mediante consciência e o conhecimento de si", com todas as técnicas das ciências morais e das ciências do homem que vão formar um saber do sujeito. (DELEUZE, 2005, p.110)

Conforme anteriormente problematizado, o sujeito não é dado, mas sim construído. Verifico também que o processo de subjetivação dentro da lógica capitalística não pode ser concebido como um processo linear, mas sim rizomático ${ }^{10}$, e em constante metamorfose, se articulando com o conceito de dobra:

\begin{abstract}
O subjetivo não é apenas o de "dentro", tampouco é mero receptáculo do lado de "fora"; é também uma dobra do lado de fora (força, como diria Gilles Deleuze) para se constituir um dentro. Não é um dentro autônomo, muito menos simples recebedor dos mecanismos de controle, mas sim, uma construção, um processo intenso de produção dessa individualidade nascido entre os poderes e os saberes para se tornar uma relação consigo (self). Processo esse heterogêneo no espaço e no tempo da produção dessa subjetividade. (COSTA, 2010, p.31-32)
\end{abstract}

${ }^{10}$ Está associado ao conceito de rizoma, desenvolvido por Deleuze e Guattari (2000). Trata-se de um emaranhado de caules, onde não se consegue distinguir nem origem, nem término. O conceito será apresentado no Capítulo 3. 
Em tese, o sujeito é produzido pelos agenciamentos ${ }^{11}$ que atuam em seu cotidiano, entre os quais estão a mídia, a família e as relações sociais que atuam também nesta produção das tecnologias do eu. As tecnologias do eu são por Foucault problematizadas como:

Tecnologias do eu, que permitem aos indivíduos efetuar, por conta própria ou com ajuda de outros, certo número de operações sobre seu corpo e sua alma, pensamentos, conduta, ou qualquer forma de ser, obtendo assim uma transformação de si mesmo com a finalidade de alcançar certo estado de felicidade, pureza, sabedoria ou imortalidade. (2008, p. 48, tradução minha)

Desta forma, os sujeitos também atuam na produção das subjetividades e, ainda, como consumidores de subjetividades. Nesse sentido, para Guattari; Rolnik, (1996):

A subjetividade está em circulação nos conjuntos sociais de diferentes tamanhos: ela é essencialmente social, e assumida e vivida por indivíduos em suas existências particulares. O modo pelo qual os indivíduos vivem essa subjetividade oscila entre dois extremos: uma relação de alienação e opressão, na qual o indivíduo se submete à subjetividade tal como a recebe, ou uma relação de expressão de criação, na qual o indivíduo se reapropria dos componentes da subjetividade, produzindo um processo que eu chamaria de singularização. (p.33, grifos do autor)

O lucro capitalista é, fundamentalmente, produção de poder subjetivo. Isso não implica uma visão idealista da realidade social: a subjetividade não se situa no campo individual, seu campo é o de todos os processos de produção social e material. O que se poderia dizer, usando a linguagem da informática, é que, evidentemente, um indivíduo sempre existe, mas apenas enquanto terminal; esse terminal individual se encontra na posição de consumidor de subjetividade. Ele consome sistemas de representação de sensibilidade, etc. - sistemas que não têm nada a ver com categorias naturais universais. (p.32, grifo do autor)

A subjetividade parece estar caracterizada de uma dupla maneira: de um lado o fato de ela habitar processos infrapessoais (a dimensão molecular) e, de outro, o fato de ela ser essencialmente agenciada a nível das concatenações de relações sociais, econômicas, maquínicas, de ela ser aberta a todas as determinações sócio-antropológicas, econômicas, etc. (p.68)

As subjetividades engendradas através dos processos de subjetivação, para serem consumidas e cumprirem o papel que lhes confere caráter de verdade, necessitam ser nomeadas, identificadas e diferidas. Aqui são constituídas as diversas identidades através de máquinas binárias. Deleuze; Parnet (1998, p. 104) explicam como se dá a lógica das máquinas binárias:

\footnotetext{
${ }^{11}$ Agenciamento, segundo Silva (2000, p.15), significa "o ato de arranjar, organizar, dispor um conjunto qualquer de elementos". Na teoria de Deleuze, este conceito é desenvolvido como o conjunto de aparatos utilizados na constituição do sujeito, negando desta forma sua naturalidade. São exemplos de agenciamentos as ideias, os enunciados, as coisas, as pessoas, os corpos e as instituições.
} 


\begin{abstract}
Máquinas binárias, bem diversas se quiserem. Máquinas binárias de classes sociais, de sexos, homem-mulher, de idades, criança-adulto, de raças, branco-negro, de setores, público-privado, de subjetivações, em nossa casafora de casa. Essas máquinas binárias são tanto mais complexas quanto se recortam, ou se chocam umas com as outras, afrontam-se, e cortam a nós mesmos em toda espécie de sentidos. E elas não são sumariamente dualistas, são, antes, dicotômicas: podem operar diacronicamente (se você não é nem a nem $b$, então é $c$ : o dualismo transportou-se, e já não concerne elementos simultâneos a serem escolhidos, e sim escolhas sucessivas; se você não é nem branco nem negro, você é mestiço; se você não é nem homem nem mulher, você é travesti; a cada vez a máquina dos elementos binários produzirá escolhas binárias entre elementos que não entravam no primeiro recorte).
\end{abstract}

Por meio das máquinas-binárias e de constantes disputas de poder, os sujeitos criados são nomeados e classificados, tecendo desta maneira as identidades, que são construídas a partir da estreita dependência com a identificação de diferença (SILVA, 2007).

Isto implica que para problematizar identidade é preciso também problematizar a ideia de diferença. As diferenças são possíveis quando a sociedade passa por um suposto processo democrático que amassa "os processos de vida social, em sua riqueza e diferenciação e, com isso, produz, a cada fornada, indivíduos iguais e processos empobrecidos" (GUATTARI; ROLNIK, 1996, p. 39). Segundo os mesmos autores, é a transformação em indivíduos por maquinarias de bloqueios da singularização que produz diferenças e identidades.

Uma vez que as identidades são maquinadas, verifica-se também que não se trata de escolhas do próprio sujeito. Ele é assujeitado a uma identidade, conforme, inspirada em Clarice Lispector, diz Ferre (2011, p.196):

Eu não sou meu nome; meu nome pertence àqueles que me chamam. Minha identidade me dão os outros, mas eu não sou essa identidade, pois se eles têm de dá-la a mim é porque eu, em mim mesma, por mim mesma, em minha intimidade, não a tenho.

Tanto identidade quanto diferença surgem da necessidade de classificar indivíduos e objetos, pois quando classificamos diferenciamos, falamos o que é e o que não é. Sobre a diferença e a produção das identidades, Vargas (2007) expõe que:

Diferença infinitesimal, diferença universal, a diferença é o alfa e o ômega, a diferença é o fundo das coisas, Tarde repete sem fatigar. A formulação inigualável, essa nós já conhecemos, mas nunca é demais repetir "existir é diferir" mas ela aparece também de vários outros modos, como o da mudança para e na mudança ou o da variação universal. Mas se a variação é o que não varia, porque segue variando, então a "identidade é apenas um mínimo, e portanto apenas uma espécie, e uma espécie infinitamente rara, de diferença, assim como o repouso é apenas um caso do movimento, e o círculo 
uma variedade singular da elipse". Logo, diferenças é o que todos temos em comum, é o caso de dizer. (p. 30, grifos do autor)

Nessas palavras complementadas, "a diferença vai diferindo sem, no entanto, ir aumentando ou diminuindo", Vargas (p. 31), ao recorrer a Silva (2007) destaca a possibilidade de pensar que "se todos tivessem a mesma identidade sua afirmação [da identidade] não faria sentido". Logo, a diferença só faz sentido se compreendida adjacente ao conceito de identidade:

As afirmações sobre diferença também dependem de uma cadeia, em geral oculta, de declarações negativas sobre (outras) identidades. Assim como a identidade depende da diferença, a diferença depende da identidade. Identidade e diferença são, pois, inseparáveis. (SILVA, 2007, p.76)

Quando Woodward (2007, p.41) considera que "cada cultura tem suas próprias e distintas formas de classificar o mundo", ele reforça o proposto por Silva e Vargas de que as identidades são fabricadas por meio da marcação da diferença e ocorrem tanto por meio de sistemas simbólicos de representação, quanto por meio de formas de exclusão social. Logo, são os sistemas simbólicos de representação de cada cultura que incluem, excluem ou classificam, produzindo as identidades e consequentemente as suas diferenças. Por isso, é importante ponderar que tanto a identidade, quanto a diferença são o resultado de um processo de produção simbólica e discursiva (SILVA, 2007).

Essas produções discursivas são pensadas e produzidas através de relações de poder, construídas nas relações sociais, no seio de cada cultura. Consequentemente, são as relações de poder que definem quem é incluído e quem é excluído de determinada identidade. Para essa definição:

\footnotetext{
Existe em nossa sociedade outro princípio de exclusão: não mais a interdição, mas uma separação e uma rejeição. Penso na oposição razão e loucura. Desde a alta Idade Média, o louco é aquele cujo discurso não pode circular como o dos outros: pode ocorrer que sua palavra seja considerada nula e não seja acolhida, não tendo verdade nem importância, não podendo testemunhar na justiça, não podendo autenticar um ato ou um contrato. (FOUCAULT, 2014, 10-11)
}

Foucault (1997) nos mostra a diferença que forma a identidade - surgida com o objetivo de separar identidades normais de anormais. Em suma, identidade é o que eu sou e que me diferencia do que eu não sou: o outro. Se eu não fosse diferente do outro, ou ainda, se eu não negasse o outro, não existiria diferença, tampouco identidade. O outro, costumeiramente, é visto como o anormal, por se diferenciar daquilo que sou. 
A sociedade capitalística, que cria o anormal, mais do que forjar identidades nos convence de que as subjetividades são um direito nosso à diferença, como problematizado por Deleuze (2005, p.113):

A luta por uma subjetividade moderna passa por uma resistência às duas formas atuais de sujeição, uma que consiste em nos individualizar de acordo com as exigências do poder, outra que consiste em ligar cada indivíduo a uma identidade sabida e conhecida, bem determinada de uma vez por todas. A luta pela subjetividade se apresenta então como direito à diferença e direito à variação, à metamorfose.

Por isso, Woodward (2007) e Silva problematizam que identidade e diferença estão intrinsecamente ligadas, e relacionadas a processos classificatórios determinados pelas relações de poder:

Dividir o mundo social entre "nós" e "eles" significa classificar. O processo de classificação é central na vida social. Ele pode ser entendido como um ato de significação pelo qual dividimos e ordenamos o mundo social em grupos, em classes. A identidade e a diferença estão estreitamente relacionadas às formas pelas quais a sociedade produz e utiliza classificações. As classificações são sempre feitas a partir do ponto de vista de identidade. (SILVA, 2007, p.82)

Para Rolnik (1997a), este ato de ordenamento e divisão que produz as identidades tem dispositivos importantes que, ao perceberem sua perda de força, ofertam "drogas" que permitem manter a ilusão, ou seja, as identidades:

Já nos momentos em que perde toda e qualquer esperança de permanecer
na mesma dobra, para manter assim mesmo sua ilusão, ele toma algumas
doses de "identidade" "prêt-à-porter". Trata-se de uma droga disponível em
profusão no mercado da mídia, sob todas as formas e para todos os gostos:
são as miragens de personagens globalizados, vencedores e invencíveis,
envoltos por uma aura de incansável glamour, que habitam as etéreas ondas
sonoras e visuais da mídia; personagens que parecem pairar acima das
turbulências do vivo e da finitude de suas figuras. Mimetizando um destes
personagens imaginários, ele passa a falar uma língua-jargão lotada de
clichês, sem ancoragem em sensibilidade alguma, o que soa especialmente
fake quando se trata de um repertório com uma certa sofisticação intelectual
(p.29).

Drogas que, segundo esse mesmo autor (p.30), mais do que permitirem a manutenção da ilusão, atuam também na "domesticação dos efeitos das forças do fora na pele: anulando o estado de estranhamento provocado pela condição de desconhecido de seus diagramas; neutralizam-se assim seus efeitos disruptivos".

Desta forma, concluo que é através do forjar diferenças para construir identidades que as maquinarias territorializam os sujeitos. Este ato de territorializar os sujeitos, chamados por Rolnik (1997b) de kits-padrão, visam atender a lógica do 
mercado para consumo das subjetividades. O sujeito dito diferente é definido a partir da lógica da normalidade (normalidade aqui entendida dentro do exposto por Veiga Neto e Foucault - mencionado anteriormente) e destoa por ser visto como perturbação (FERRE, 2011).

\section{2 - Tessituras da modernidade: o sujeito jovem, a identidade e a diferença}

Após compreender a identidade e a diferença enquanto processos construídos discursivamente por meio das relações de poder e da necessidade de classificar para ungir o outro com a diferença, passarei a analisar os conceitos de jovem e juventude, reverberando o apresentado até aqui sobre identidade e diferença.

Juventude e jovem ou adolescência e adolescente são identidades inventadas na sociedade burguesa industrial com a finalidade de vigiar, domesticar ou disciplinar corpos visando à formação do adulto ideal, este entendido como o caucasiano, do sexo masculino, heterossexual, reprodutivo, livre de doenças e anomalias, proprietário, sujeito distante da delinquência juvenil e da sexualidade perigosa.

De acordo com César (1998), o adolescente ideal, construído por meio de dispositivos entre os quais está a cooperação crescente no âmbito da medicina, psicologia, pedagogia, pais e professores, é o adolescente livre dos desajustes no comportamento, livre também das ideias de imaturidade, dependência e conformismo. Ao superar tais anomalias, estaria a fase da adolescência concluída com êxito:

\footnotetext{
Tal como formulado pela psicopedagogia, o conceito de adolescência deve ser pensado em relação a um conceito de maturidade compatível com a sociedade industrial contemporânea. Atingir esse ideal de maturidade significaria suplantar com êxito a "fase" da "adolescência", instaurando-se então aquela etapa da vida marcada pela independência afetiva e financeira, na qual o indivíduo estaria pronto para construir a sua própria família, para provê-la adequadamente, para produzir rebentos saudáveis e educá-los de maneira satisfatória (CÉSAR, 1998, p. 23).
}

Apesar de vista como construção da sociedade burguesa, o que remeteria a invenção da juventude e da adolescência para meados do final do século XVIII e começo do século XIX, é possível encontrar relatos sobre jovens e adolescentes na história antes mesmo disto: 
A delimitação do que seja infância estabelece o limite com a idade adulta, isto é, com a idade da suposta capacidade produtiva. Além da criança e do adulto, a história já contava com a figura do jovem, revelado/apresentado em diferentes personagens como os jovens guerreiros de Atenas, os guerreiros das Cruzadas, os cavaleiros de Arthur, dentre outros. Outros personagens iriam surgir e, dentre eles, o adolescente, que teve sua primeira apresentação através da música de Wagner (SILVA, 2011, p. 13).

O jovem mostrado na música de Wagner é reconstruído e configurado na Europa, e revelado como o herói da sociedade, pois com suas características singulares, como um "messias", redimiria a humanidade (SILVA, 2011; ARIĖS, 1981).

Sobre a criação da juventude e adolescência, Ariès (1981, p.46-47) destaca que "a juventude apareceu como depositária de valores novos, capazes de reavivar uma sociedade velha e esclerosada... Daí em diante, a adolescência se expandiria, empurrando a infância para trás e a maturidade para a frente". A inserção da juventude entre a infância e a vida adulta reforça o seu caráter de preparação, que é vista como necessária para a vida produtiva. Sendo a vida produtiva, a vida adulta, a escola é forjada como o dispositivo de controle que será essencial para o alcance deste objetivo.

Tragtenberg (2003) destaca o papel da escola como dispositivo de controle. Como apontado por esse autor: Os espaços frequentados pelos "adolescentes", em especial o espaço
escolar, estão marcados pelo autoritarismo, pela ausência de possibilidade
de criação artística, com um sistema de vigilância e punição instalado que
classifica os "bons" e os "maus". Não há diálogo e as atividades estão
desvinculadas da vida, limitando-se a elencar conteúdos desprovidos de
sentido. O sem-sentido a que estão submetidos acaba produzindo novos
sentidos e muitas vezes esta produção se manifesta de forma violenta frente
ao coletivo. (p. 13-14)

A escola é designada, então, não apenas como dispositivo de controle, mas também como dispositivo produtor da adolescência e da juventude. Formatando a identidade juvenil, em processos que recusam as singularidades apresentadas pelo jovem, visto que, ao adentrar este espaço, eles são compelidos a se constituírem como protótipos do exemplar mais exato, mais perfeito de adultos vislumbrado pela sociedade dentro dos padrões já elencados. Sobre isto, Ariès (1981, p.11) problematiza:

Isso quer dizer a criança deixou de viver misturada aos adultos e de aprender a vida diretamente, através do contato com eles. A despeito das muitas reticências e retardamentos, a criança foi separada dos adultos e mantida à distância numa espécie de quarentena, antes de ser solta no mundo. Essa 
quarentena foi a escola, o colégio. Começou então um longo processo de enclausuramento das crianças (como dos loucos, dos pobres e das prostitutas) que se estenderia até nossos dias, e ao qual se dá o nome de escolarização.

Sobre a escola, que tem fracassado como dispositivo de governamento e dispositivo de ensino da educação formal, acredito que a inserção das artes, a partir de propostas que permitam a manifestação das identidades juvenis, pode reverter o quadro. Saliento, porém, que, apesar da invisibilidade, os jovens resistem e reinventam a escola juntamente com educadores que incorporam em suas práticas didáticas os gritos e as vozes da juventude. Não estou sozinho na minha crença, pois:

A saída pela arte pode transformar essa relação que tenta submeter a "juventude" a um lugar inferior em potência, pode se re-criar como resistência e produzir formas de se dizer, de apontar, de se manifestar: produções que deixam aparecer o sujeito que ao criar e viver pode se re-inventar. (CAMPOS, 2008, p.45)

Desta forma, percebo que a adolescência, bem como a juventude compreendida como uma fase de transição, é reconstruída pela sociedade burguesa, como uma fase de maturação para a vida adulta.

Sobre as fases da vida, Foucault (2006) apresenta como cada uma é concebida, compartimentada e destaca a visão binária sobre cada uma delas:

Há pouco citei a separação dos pitagóricos entre infância, adolescência, juventude, velhice, etc. (havia outros modos). O interessante, porém, é, por um lado, a importância concedida à forma de vida particular a estas diferentes fases e [por outro] a importância concedida, do ponto de vista ético, a uma boa correlação, no individuo, entre o modo de vida que ele escolhia, a maneira como levava sua existência e o período de idade em que estava. Um jovem devia viver como jovem, um homem maduro como homem maduro, um idoso como idoso. (p.135-136)

Sobre a construção discursiva da juventude pela sociedade burguesa e os estereótipos a ela associados, é importante também considerar as diferenças históricas que envolvem questões como classe, raça/etnia e gênero apontadas por Groppo (2000, p.16):

Por exemplo, são importantes as implicações de classe nas diferentes experiências da juventude. A juventude - $\mathrm{e}$, antes, a infância - foi vivida primeiro pelas classes burguesas e aristocratas, para depois tornar-se um direito das classes trabalhadoras. Já a juventude típica do século $X X$, a juventude "rebelde-sem-causa", radical ou delinquente, é, primordialmente, uma imagem baseada no jovem das chamadas "novas classes médias". Á juventude ideal e primitivamente construída - urbana, ocidental, branca e masculina - outras juventudes vieram (ou tentaram) juntar-se - rurais, não ocidentais, negras, amarelas e mestiças, femininas etc. São outras juventudes que construíram para si representações e relações sociais 
concretas distintas, em diversos graus, do padrão considerado ideal ou típico da juventude em sua época.

Percebo dentro do apresentado por Groppo, pois ainda que o debate sobre classes sociais por si só não explique a juventude, as juventudes de classes trabalhadoras surgem pós-juventudes nas classes mais favorecidas. A diferença temporal está associada à necessidade das classes trabalhadoras de inserir os jovens no mercado de trabalho para complementar a renda, fazendo a transição direta da infância para a vida adulta.

O próprio Groppo (2000, p.17) destaca que "em muitos casos, grupos juvenis de operários, de não brancos ou não ocidentais adotam os mesmos símbolos, roupas e gostos culturais dos grupos juvenis brancos de classe média". Isso me permite problematizar que as diferenças e semelhanças podem ser encontradas não apenas dentro de um segmento, mas também de forma transversal perpassando vários segmentos.

Outro ponto que gostaria de sublinhar no excerto acima é a ideia de que a juventude também constrói discursivamente o conceito de juventude, quando cria ou reinventa as diversas discursividades juvenis que escapam aos padrões propostos pela modernidade.

A adolescência/juventude é contingenciada como um período marcado pela necessidade de "contínua observação vigilante, e da prescrição de um conjunto de atividades que mantivessem corpos e mentes ocupados e cansados, sem dar espaço para o aparecimento do menor traço do 'desejo'" (CÉSAR, 1998, p. 31-2). Observo aqui a ideia do jovem como animal, em quem, quanto mais novo, mais fortes os poderes instintivos, e maior a possibilidade de ele causar problema. Diante desta perspectiva, percebo a necessidade de controle engendrada em um conjunto de dispositivos:

O discurso da psiquiatria, da pedagogia, da psicologia e também o discurso
jurídico, dentre outros, foram constituindo o sujeito adolescente, como um
problema a ser resolvido. Problema este que será o seu encaminhamento às
fronteiras do mundo adulto, inventando para isso normas de conduta,
princípios gerais de educação, formação moral, fortalecimento do corpo e da
mente, a ocupação do tempo e da mente, sua preparação para quando
ocupar lugares de poder, ou seja, para o ponto de chegada a um lugar de
referência - o da maturidade e da independência financeira. (SILVA, 2011,
p.15, grifos do autor)

Ariès (1981, p. 48) depreende que: 
Tem-se a impressão, portanto, de que, a cada época corresponderia uma idade privilegiada e uma periodização particular da vida humana: a "juventude" é a idade privilegiada do século XVII, a "infância", do século XIX, e a "adolescência", do século XX.

Estudiosos como Ariès (1981), Campos (2008) e Silva (2011) indicam o século XX como o século da adolescência. Acrescento, também, como sendo o século da juventude com expansão até o século XXI, considerando que, ao menos no Brasil, neste começo do século, muitas vezes de forma pejorativa, o discurso de juventude vem ocupando os noticiários da mídia, caracterizando o jovem ora como problema social, ora como fonte de características que contribuem com a mídia e o marketing para venda de produtos.

César (1998) aponta que estas construções acerca da juventude retomam a própria invenção do conceito de adolescente/juventude. Para a autora, o adolescente não é uma criação da ciência positivista iluminista, e sim uma invenção resgatada por esta ciência que, no período iluminista, com seus métodos de investigação, lapidou a figura do adolescente e dotou de importância a adolescência para a construção do adulto ideal, necessário à sociedade burguesa. Porém a ciência também voltou os olhos para aquilo visto como mais pejorativo na juventude, a fim de pensar dispositivos que permitissem a construção não apenas do adulto ideal, mas também dos jovens idealizados. César destaca que:

A celebração dessa "nova descoberta" voltou os olhos da ciência para esse
intervalo etário, e os pesquisadores passaram a apontar os "problemas"
constitutivos desse "novo" grupo humano, tais como o aumento da incidência
das desordens mentais juvenis, a ociosidade, o sexo desregrado, o aumento
da criminalidade e as crescentes evidências do aumento da delinquência
entre os jovens. (p.32)

Considero que os dispositivos disciplinadores como a família, a escola e a medicina eram tidos como exitosos quando conseguiam eliminar neste sujeito ações consideradas como instintivas, entre elas a delinquência e a sexualidade do adolescente. Quando ao passar pela adolescência/juventude tais características continuam a ser observadas, logo os mesmos dispositivos são responsabilizados pelo fracasso.

A adolescência vista como transitória, além dos estigmas da delinquência e da sexualidade, carrega consigo o ideário de rebeldia e insurgência ao socialmente aceito (CÉSAR, 1998). No entanto, também ganha ares de salvação quando the é atribuído o papel de pilar de uma nova sociedade. Por isso, o desejo e o método burguês em 
formar (ou treinar) o adolescente, através de seu conjunto de dispositivos, são tidos como o único modo de chegar ao adulto ideal, saudável e maduro.

Reforçam o discurso da juventude como uma fase de transição as ideias do não ser mais criança, porém não ser ainda adulto, como cita César:

O conceito de "adolescência" caracteriza o período da vida ou a fase do desenvolvimento em que o indivíduo não é. O "adolescente" é aquele que não é mais uma criança, mas ainda não é um adulto, ideia expressa coloquialmente na imagem da "adolescência" como "idade do retalho": tratase de indivíduos grandes demais para serem "descartados", e pequenos demais para serem "aproveitados". (1998, p.47)

Deste modo, a juventude e adolescência são explicitadas como alguém que hoje nada é, mas que precisa ser construído para vir a ser. Esta perspectiva de futuro, não tem o adolescente ou o jovem como foco, mas a construção do futuro indivíduo adulto, aquele que poderá redimir todas as mazelas da sociedade não disciplinada.

Para a referida autora, esta criação que se popularizou tem autores e origens:

Psicólogos, políticos e pedagogos determinados a criar uma nova imagem de juventude foram influenciados pelas ideias que circulavam simultaneamente entre os EUA e Europa, e os reformistas persistiram na implantação de mudanças sociais baseadas na ideia da vulnerabilidade do período da "adolescência" (CÉSAR, 1998, p.38).

Em tese, foram estes profissionais que na modernidade contribuíram para criar o discurso que marcou e normatizou a identidade juvenil. $E$ a estes profissionais se juntam, entre outros, dispositivos como a igreja, a família, a mídia, a escola, a medicina, a legislação, conforme mencionados por Campos (2008), que imprimiram na juventude um caráter de universalidade, além do caráter identitário. Veiga-Neto problematiza o funcionamento destes marcadores identitários:

E nesse crescente elogio da diferença, os marcadores identitários - aqueles
símbolos culturais que funcionam para diferenciar, agrupar, classificar,
ordenar - inscrevem-se fundamentalmente no corpo. É sobretudo no corpo
que se tornam manifestas as marcas que nos posicionam: ser (ou não ser)
baixo, negro, magro, loiro, deficiente, etc.; ter (ou não ter) tal ou qual sexo,
idade, língua, etc.; partilhar (ou não partilhar) de tal ou qual costume, tradição,
território, classe social, etc. (VEIGA-NETO, 2000, não paginado)

Nestes termos a idade passa a ser um dispositivo definidor de identidades, que atribui a esta fase um caráter de moratória ${ }^{12}$, ou seja, como um período de preparação, uma transição, onde determinadas situações e atividades devem ser furtadas de quem

12 Sobre moratória social, leia Groppo (2015) e Dick (2003). 
está na juventude, pois os considerados neste território estão sendo preparados, preparados para ser adultos competentes e bem sucedidos.

Outro aspecto da juventude enquanto fase são os seus interditos. Uma vez definido como jovem, o sujeito está localizado, posto em determinado lugar, e passa a ter legitimidade (ou não) para determinadas ações e lugares. Nesse aspecto, por conseguinte:

\begin{abstract}
Em uma sociedade como a nossa, conhecemos é certo, procedimentos de exclusão. O mais evidente, o mais familiar também, é a interdição. Sabe-se bem que não se tem o direito de dizer tudo, que não se pode falar de tudo em qualquer circunstância, que qualquer um, enfim, não pode falar de qualquer coisa. (FOUCAULT, 2014, p.9)
\end{abstract}

Com base em Foucault, Frezza (2009) problematiza a legitimidade que certos dispositivos conferem ao se falar da juventude, como é o caso das leis, da psicologia, da medicina e da pedagogia. Tais dispositivos ganharam, na modernidade, destaque na formulação da identidade juvenil.

Ainda que não se trate de uma relação binária, ser jovem, nesta lógica, dá ao jovem legitimidade para falar de determinados assuntos e atuar em determinados espaços. Ao mesmo tempo, estaria deslegitimado a falar de outros assuntos, em especial aqueles sobre os quais não teria credibilidade para se posicionar, por ser jovem, ou melhor, novo, ou ainda inexperiente demais. Sobre essa fronteira que divide o território da juventude e da vida adulta, criando ditos e interditos, Barbalho (2006), ao citar Bourdieu (1983), destaca a arbitrariedade desta fronteira, que indica que o que é permitido ou não a cada território é definido pelo adulto. Trata-se aqui mais uma vez da lógica adultocêntrica governando os corpos das juventudes. Não quero, porém, colocar a juventude ou adolescência no papel de oprimido, e o adulto de opressor, tendo em vista que vejo como pertinente o problematizado por Veiga-Neto:

No caso especifico da idade, então, não basta simplesmente declararmos que somos todos diferentes, que cada um tem a sua identidade etária e que, portanto, cada um procure o seu respectivo grupo - dos adolescentes, dos jovens, dos velhos, etc. Não basta dizermos que entendemos e aceitamos os outros grupos etários, nos seus direitos, nas suas maneiras de ser e de se relacionar conosco. É nas situações práticas que tudo isso complica. Assim, por exemplo, frente a qualquer conflito de interesses, logo cada um invoca seu status etário para fazer valer suas prerrogativas, seja ocupando o papel de "mais experiente" (leia-se "mais velho"...), seja ocupando o papel de mais "desprotegido". Além disso, é bastante difícil imaginar que se possa conviver com diferentes grupos etários sem atribuir-lhes diferentes juízos de valor [...] mais do que qualquer outra, as identidades etárias são necessariamente móveis. Ainda que qualquer identidade jamais seja fixa e nem mesmo estável, 
no caso das idades é evidente per se que, se há um agrupamento cujo critério maior de formação e ordenamento é o tempo vivido, é suficiente viver esse tempo para que cada um acabe percorrendo os diferentes grupos [...] de pouco adianta dizer aos mais velhos que o mundo mudou, que, quando eles eram jovens, ser jovem era outra coisa; o que interessa é que eles se sentem "mais experientes" e, portanto, "melhores" do que os mais jovens. (2000, não paginado [grifos do autor])

Debert (2010, p. 59-60) destaca possíveis motivos para cronologização da vida na sociedade moderna:

$\mathrm{Na}$ explicitação das razões que levaram à cronologização da vida pesos distintos podem ser atribuídos a dimensões diversas. A padronização da infância, adolescência, idade adulta e velhice pode ser pensada como resposta às mudanças econômicas, devidas, sobretudo, à transição de uma economia que tinha como base a unidade doméstica para outra baseada no mercado de trabalho. Inversamente, ênfase pode ser dada ao Estado moderno, que - na transformação de questões que diziam respeito à esfera privada e familiar em problemas de ordem pública - seria, por excelência, a instituição orientadora do curso da vida, regulamentando todas as suas etapas, desde o momento do nascimento até a morte, passando pelo sistema complexo de fases de escolarização, entrada no mercado de trabalho e aposentadoria.

O curso da vida moderno é reflexo da lógica fordista, ancorada na primazia da produtividade econômica e na subordinação do indivíduo aos requisitos racionalizadores da ordem social. Tem como corolário a burocratização dos ciclos da vida, através da massificação da escola pública e da aposentadoria.

Porém é preciso romper com tais interditos, visto que, conforme exposto por Campos (2008), as características atribuídas à identidade juvenil se confirmam como construções discursivas, pois podem ser encontradas em outras idades:

A questão que se apresenta, nesse momento, onde o que menos importa é dar nome às "coisas", é verificar que aquilo que antes se definia como situações, comportamentos, sentimentos presentes na vida "adulta", o que demonstra que o que se define e se coloca como característica da "adolescência" não é de sua exclusividade... Ao adulto, foi reservado o lugar de pessoa sisuda, carrancuda, séria, quando, na verdade, nem todos os "adultos" vivem dessa forma. Foram padrões enganosos que colocaram "adolescentes", "jovens" e "adultos" em lugares pré-determinados. (CAMPOS, 2008, p. 37)

Sobre estas pré-determinações, Foucault (2006, p.136) problematiza a partir da ética greco-romana:

Um jovem devia viver como jovem, um homem maduro como homem maduro, um idoso como idoso. Ora, diz Sêneca, pensando muito provavelmente naquele gênero de repartição tradicional, não posso estar de acordo com as pessoas que repartem sua vida em fatias e que não têm a mesma maneira de viver conforme estejam em uma ou outra idade. Sêneca propõe substituir esta repartição por uma espécie de unidade - unidade, se quisermos, dinâmica: unidade de um movimento contínuo que tende para a velhice. 
Como apontado por Foucault, Silva (2011, p. 14) também salienta que cada fase da vida terá definições e características a elas associadas:

Cada divisão do desenvolvimento irá determinar formas de definição e, portanto, do que se deve esperar para cada etapa de vida: a alegria na infância; a possibilidade ainda de ser irresponsável na adolescência; a entrada no mundo do trabalho para a juventude; a responsabilidade de uma produção na vida e a constituição de uma nova família, na vida adulta; e por fim, a velhice passa a ser significada como um desfrutar das recompensas de uma vida de trabalho. Está é uma forma - ainda presente no século XXI - de dividir a vida e identificar suas características.

Foi o processo de diferenciação entre a juventude, a infância e a vida adulta que criou a identidade juvenil. E neste caso, diferente do que é exposto por Woodward (2007), não se tornou aquilo em que se tornou como norma, mas como o que deve ser visto, imprimindo na juventude esse caráter de redenção. Nessa perspectiva:

\begin{abstract}
Questões relativas à idade - como tempo vivido pelo corpo - tomando-a como tema ou categoria mobilizada em processos identitários que considero cada vez mais difundidos e penetrantes. Como tema ou categoria, é claro que a idade não está e não "funciona" sozinha, isso é, ela não está (nem de perto) isolada das demais categorias identitárias. De fato, existe uma teia de relações entre elas; talvez o melhor exemplo disso se tenha nos diferentes significados que a idade assume em função do gênero: "ser velho" é muito diferente de "ser velha". Além disso, alguns marcadores identitários - como o vestuário, os adereços (na roupa ou diretamente no corpo), as marcas físicas (cor, textura e corte dos cabelos, cor da pele, maquiagens, etc.), a gesticulação, o modo de falar, etc. - acabam funcionando não só para representar um determinado grupo étnico (ou uma tribo), como, ao mesmo tempo, para representar esse ou aquele grupo etário. (VEIGA-NETO, 2000, não paginado)
\end{abstract}

Se o que criou a identidade juvenil foi a sua diferenciação entre as outras fases da vida, ao analisarmos o trecho abaixo, isto pode ser questionado:

\begin{abstract}
Ver e viver experiências articuladas, contemplando a possibilidade de variadas respostas e combinações de respostas, de idas e vindas, bem além das qualificações apriorísticas de progressões e regressões seria uma maneira de considerar que, no devir das experiências e respostas existenciais uma idade não elimina a outra, mas a contém. O menino e a menina, o jovem e a jovem, estão na pessoa adulta ou velha, e inclusive os meninos e as meninas podem responder como adultos em determinadas situações. Em vez de pensar em termos de regressões, inadaptações ou reduções, poderíamos reclamar o direito de jogar, em cada momento, com todas e cada uma das cartas de nossa experiência (dos primeiros anos ou tardia, pequena ou grande), de maneira que, em cada itinerário pessoal, o tempo nos fosse amigo e não cárcere, permitindo assim uma identidade flexível e diversificada. (LLORET ${ }^{13}$, apud CAMPOS, 2008, p. 49-50)
\end{abstract}

${ }^{13}$ LLORET, C. "As outras idades ou as idades do outro". In: LARROSA, J \& LARA, N. P. (orgs). Imagens do Outro. Petrópolis, RJ: Vozes, 1998 
Logo, se as fases se sobrepõem não é possível definir e sustentar características como sendo únicas e exclusivas da juventude, e com isso penso que o pilar que sustenta a construção discursiva do conceito de juventude fica comprometido, tendo por base o apresentado por Silva (2011, p.14, grifos do autor):

Indivíduos, em suas subjetividades, ultrapassam os territórios e questionam os critérios da demarcação destes. Vemos isso acontecer, em nosso cotidiano, quando estamos diante de um indivíduo considerado adulto e que é referido como aquele que ainda não assumiu suas responsabilidades de adulto e ainda não dá conta de si, o que o caracteriza como um adolescente. O oposto também é verdadeiro: um adolescente muito responsável e muito eficiente é, via de regra, referido como adulto. Há também relatos de pessoas que não reconhecem, em sua vida, o período da adolescência, pois tiveram que assumir responsabilidades logo depois da infância: "quando perdi meu pai, tive que trabalhar"; "minha mãe me colocava para cuidar dos meus irmãos, desde que eu era criança”

Não bastasse a intergeracionalidade das características atribuídas, a sua invenção discursiva, burguesa e moderna apresenta outras dificuldades em se firmar:

Encontramos, do século XIX até o início do século XX [acrescentaria o XXI também], uma noção de juventude engendrada pelas práticas e discursos das instituições sociais oficiais, estatais, liberais, burguesas, capitalistas etc., noção legitimada pelas ciências modernas. Ao desvendar este paradigma mais geral da criação das juventudes na modernidade, iremos deparar-nos com a dificuldade de aplicação da maturidade social, em relação à realidade sócio-cultural múltipla e complexa. (GROPPO, 2000, p. 18, [grifos meus])

Isso mostra que a juventude, ainda que inventada, também se reinventa e com isso escapa e ressignifica o que a sociedade burguesa constituiu, engendrou e normatizou como sendo juventude. É a juventude agindo como potência e se utilizando das contradições da própria sociedade moderna e desconstruindo a universalidade e singularidade impostas pelos forjadores dos conceitos de jovem e juventude. Dessa forma, na modernidade:

A criação das juventudes é um dos fundamentos da modernidade, e a existência da multiplicidade quase que incontrolável de juventudes é um sinal de que este fundamento, assim como outros fundamentos da modernidade, possui suas contradições. A diversidade das juventudes modernas é um dos frutos das contradições de projetos modernizadores que objetivaram criar as faixas etárias preparatórias à maturidade. $O$ entendimento dessa diversidade passa pela aplicação combinada de outras tantas categorias sociais que, assim como a juventude, se referem a realidades sociais contraditórias: classe social, estrato social, etnias, gêneros, oposição urbano-rural, relação nacional-local, global-regional etc. (GROPPO, 2000, p.18-19)

Para além da normatização e da preparação do adulto ideal, quais outros interesses em inventar a adolescência e a juventude? Por que isto poderia ser importante à sociedade burguesa? 
César (1998) considera que a invenção da adolescência, e posso dizer também o prolongamento da juventude dos 24 para os 29 anos, ainda que não em sua totalidade compreendida também como um período de moratória, atende a necessidade de lidar com a falta da mão de obra qualificada demandada pelo mercado e, ao mesmo tempo, o excesso de mão de obra circulante. No Brasil do fim do século XX e início do século XXI, com a expansão do ensino técnico, a juventude torna-se o foco da qualificação profissional das redes de ensino. Lembro que o ensino técnico no Brasil é uma modalidade que visa em especial preparar os jovens oriundos de classes menos favorecidas, de forma rápida. Sua inserção no mercado de trabalho em grande parte ocorre em vagas cujos salários são inferiores aos de graduados.

Ainda, neste raciocínio Campos (2008) expõe que as estereotipias associadas aos jovens e adolescentes são construções discursivas culturais, ou seja, mudam e podem não existir quando se analisa diferentes sociedades. Foucault (2006, p. 107) complementa dizendo que:

Todos sabemos que, certamente, em todas as sociedades o ingresso do adolescente na vida, sua passagem à fase que denominamos "adulta", é problemática e que a maioria das sociedades ritualizou fortemente esta difícil e perigosa passagem da adolescência à idade adulta.

A partir do momento em que a juventude passa a ser uma identidade e se constitui o sujeito jovem, essa construção passa a incluir e a excluir indivíduos. É a partir das representações do ser jovem que emergem as características da juventude. Desta forma, a quem não possui estas características fica negada a identidade juvenil. Isto ocorre porque as identidades são relacionais, ou seja, elas se rivalizam entre si, possibilitando condições para que as não identidades existam, pois é a partir da diferença que se dá condições para a existência.

Compartilho do proposto por Woodward (2007), ao dissertar sobre identidade e diferença. Penso que a caracterização da identidade juvenil é a negação das outras identidades etárias como o ser criança, adulto ou idoso. Isto ocorre, pois a existência de uma identidade carece da negação de outras e suas similaridades. Observo com isso que a diferença é sustentada pela exclusão. Desta forma, se você é jovem não pode ser idoso, adulto ou criança.

De acordo com Silva (2005, p. 87)

A diferença é essencialmente um processo linguístico e discursivo. A diferença não pode ser concebida fora dos processos linguísticos de 
significação. A diferença não é uma característica natural: ela é discursivamente produzida.

Woodward (2007, p.40) problematiza que a "diferença pode ser compreendida como aquilo que separa uma identidade da outra, estabelecendo distinções" e que a construção da identidade é tanto simbólica quanto social. Neste aspecto:

Três segmentos foram claramente demarcados: a juventude e a vida escolar; o mundo adulto e o trabalho; e a velhice e a aposentadoria. O apagamento das fronteiras que separavam juventude, vida adulta e velhice e das normas que indicam o comportamento apropriado aos grupos de idade é, segundo Moody (1993), o reflexo de uma sociedade pós-fordista, marcada pela informatização da economia, pela desmassificação dos mercados de consumo, da política, da mídia e da cultura, e pela fluidez e multiplicidade de estilos de vida, frutos de uma economia baseada mais no consumo do que na produtividade. (DEBERT, 2010, p. 60-61)

Quais os símbolos que marcam e caracterizam a produção discursiva do jovem? Ou, como questionado por Silva (2007), é possível definir a identidade de uma pessoa pelas coisas que ela usa? Sendo assim é possível dizer que determinadas características são exclusivas de uma identidade? Quais os significantes importantes da diferença e da identidade juvenil?

As respostas para tais inquietações estão associadas às diversas culturas encontradas. Uma vez que a identidade juvenil é uma construção discursiva, impregnada por representações simbólicas, e que os símbolos e sua interpretação constituem uma cultura. Logo, podemos dizer que tanto a identidade juvenil, quanto os símbolos que a caracterizam não são rígidos, mas fluidos e construídos a partir do horizonte de cada cultura.

Woodward (2007, p.40) vem evidenciar esta hipótese, ao dizer que a identidade é o oposto da diferença e que esta diferença é ao mesmo tempo simbólica, social e estabelecida, "ao menos em parte, por meio de sistemas classificatórios". Estes sistemas classificatórios são definidos pelas culturas que realizarão o processo de classificação. Isto também reforça a ideia de fluidez e insegurança das identidades. Todavia:

Ao afirmar uma determinada identidade podemos buscar legitimá-la por referência a um suposto e autêntico passado - possivelmente um passado glorioso, mas de qualquer forma, um passado que parece real - que poderia validar a identidade que reivindica. (WOODWARD, 2007, p. 27)

No caso da juventude brasileira, esse passado está atrelado à luta contra a ditadura, iniciada nos anos sessenta e que perdurou até a primeira metade dos anos noventa, e aos caras pintadas, movimento do impeachment do presidente Fernando 
Collor de Melo. Este é o passado glorioso e o referencial de juventude considerado como desejado, uma juventude dita como ativa e participativa ${ }^{14}$. Ainda que se crie uma concepção de juventude ideal, Woodward (2007, p.35) desconstrói essa ideia ao expor o caráter fluido da identidade dizendo que as identidades "não são essências fixas" e nem "estão presas a diferenças que seriam permanentes e valeriam para todas as épocas".

Sobre tais diferenças que desconstroem a rigidez conceitual, Groppo reforça o caráter de construções discursivas socioculturais:

A multiplicidade das juventudes não se funda num vazio social ou num nada cultural, não emerge de uma realidade meramente diversa, ininteligível e esvaecida. Tem como base experiências sócio-culturais anteriores, paralelas ou posteriores que criaram e recriaram as faixas etárias e institucionalizaram o curso da vida individual - projetos e ações que fazem parte do processo civilizador da modernidade. (GROPPO, 2000, p.19)

Diante disto, pressuponho que as concepções de juventude foram construídas a partir de "momentos particulares do tempo" (Woodward, 2007, p.38), de diferenças socioculturais (Groppo, 2000) e de posições assumidas como constituintes de identidades (Woodward). Assim, como nenhuma identidade é dada, ou natural, o mesmo se aplica à identidade juvenil, como constata Silva (2007):

Primeiramente, a identidade não é uma essência; não é um dado ou um fato
- seja da natureza, seja da cultura. A identidade não é fixa, estável, coerente,
unificada, permanente. A identidade tampouco é homogênea, definitiva,
acabada, idêntica, transcendental. Por outro lado, podemos dizer que a
identidade é uma construção, um efeito, um processo de produção, uma
relação, um ato performativo. A identidade é instável, contraditória,
fragmentada, inconsistente, inacabada. A identidade está ligada a sistemas
de representação. A identidade tem estreitas conexões com relações de
poder. (p.97)
Além de serem interdependentes, identidades, identidade e diferença
partilham uma importante característica: elas são o resultado de atos de
criação linguística. Dizer que são resultado de atos de criação significa dizer
que não são "elementos" da natureza, que não são essências, que não são
coisas que estejam simplesmente aí, a espera de serem reveladas ou
descobertas, respeitas ou toleradas. (p.76)

Além da criação, Woodward (2007, p.38) verifica e também retoma o processo de produção discursiva em que "a identidade é vista como contingente; isto é, como o produto de uma intersecção de diferentes componentes, de discursos políticos e culturais e de histórias particulares".

14 Como juventude ativa e participativa, estão as construções discursivas acerca dos jovens universitários que lutavam contra a ditadura militar no Brasil (1964-1985), ou ainda referente ao jovem visto como protagonista conforme formulação de organismos internacionais como a UNESCO. 
Deste modo, observo que o ato de ressaltar as diferenças entre o ser jovem e o ser adulto ou o ser criança são os fatores inerentes à demarcação do que é ser jovem. É a partir da demarcação que se dá a construção do conceito de juventude. Logo, se são necessárias demarcações para a identidade juvenil, elas não são criaturas do mundo natural ou de um mundo transcendental, mas do mundo cultural e social. Somos nós que as fabricamos, no contexto de relações culturais e sociais. A identidade e a diferença são criações sociais e culturais e por isso precisam ser nomeadas, segundo Silva (2007), e, acredito, construídas discursivamente.

Assim como Groppo (2000), verifico que mesmo dentro de uma mesma cultura ou geração não há singularidade ou universalidade em suas características. Isso ocorre devido às territorialidades (urbano, rural, região), à etnia, aos gêneros, à classe social, dentre outros elementos que produzem diferenças, mesmo que dentro da mesma geração de jovens. Groppo também problematiza que:

\begin{abstract}
A julgar pelo critério em que, para Mannheim, se baseia a situação geração, a experiência comum de uma transformação biológica - o curso natural da vida -, a geração poderia ser considerada uma vivência social criada a partir de um fundamento natural. No entanto, de acordo com o conceito de juventude que aqui procuro definir, mesmo as faixas etárias e as categorias sociais delas oriundas são criações sócio-culturais; jamais um dado puro e simples da natureza. O que temos, na verdade, tanto no conceito de juventude quanto no de geração, é a possibilidade de se criarem representações e relações sociais. No caso, relações e representações socialmente estabelecidas a indivíduos e grupos definidos como jovens. (GROPPO, 2000, p.20-21)
\end{abstract}

Bem como o referido autor, considero pertinente negar a naturalização do jovem e da juventude por meio da utilização da ideia de diferentes gerações juvenis uniformes, visto que o próprio conceito de geração também se trata de uma construção identitária discursiva, fundada sobre a pretensa unicidade geracional e o fomento apenas às diferenças geracionais.

Por isso, se juventude é definida pela linguagem, sendo ela instável, logo o conceito de juventude é carregado também de instabilidade e indeterminação. Desta forma, assim como a identidade juvenil é uma construção simbólica, discursiva e sociocultural, podemos dizer que o conceito e a ideia de juventude também o são.

Retomando a ideia de que ter uma identidade é não ter a outra, ser jovem é apenas uma maneira conveniente de se dizer: não é adulto e não é criança. E o ser jovem é marcado por uma carga de representações simbólicas que vão variar culturalmente. Neste aspecto fica claro que: 
A identidade e a diferença estão, pois, em estreita conexão com relações de poder. O poder de definir a identidade e de marcar a diferença não pode ser separado das relações mais amplas de poder. A identidade e a diferença não são, nunca, inocentes. (SILVA, 2007, p.81)

Quando se diz "nós jovens" e "eles adultos", o nós e o eles, como assegura esse autor, não são apenas simples categorias gramaticais, "mas indicadores de posições de sujeito fortemente marcadas por relações de poder. Podemos dizer que onde existe diferenciação - ou seja, identidade e diferença - aí está presente o poder" (p.82). Deste modo, a partir do momento em que se marca o início e o fim da juventude, ou ainda, quais as condições são próprias do sujeito juvenil, aí está a demarcação de poder.

O poder está no ato de demarcar quem é, ou não, jovem. No ato de demarcar se incluem e ao mesmo tempo se excluem outros tantos. No mesmo binarismo de nós e eles, bons e maus, normais e anormais estão os jovens e adultos, ou os jovens e as crianças.

Do mesmo modo, demarcar uma faixa etária carrega consigo poderes e imposições. Isso é verificado na demarcação da juventude como sendo dos 15 aos 29 anos. Como isso foi definido? A que interesses serve esta definição?

Nesta acepção existe um campo de disputa, fazendo com que ela não seja universalmente aceita. Sobre as disputas na designação das identidades, exponho que:

\begin{abstract}
A identidade, tal como a diferença, é uma relação social. Isso significa que sua definição - discursiva e linguística - está sujeita a vetores de força, a relações de poder. Elas não são simplesmente definidas, elas são impostas. Elas não convivem harmoniosamente, lado a lado, em um campo sem hierarquias; elas são disputadas. (SILVA, 2007, p.81)
\end{abstract}

Isto embasa a construção da identidade juvenil no final do século $X X$ e início do século $X X I$, e o desejo de determinados grupos sociais de criar políticas governamentais para a juventude, que entendiam como grupo excluído e desamparado, por não ser nem criança e nem adulto. A partir de então, iniciou-se o debate para a construção de políticas sociais.

Concluo esta problematização observando que a identidade juvenil na burguesia é recriada como uma fase de transição da infância/adolescência para a vida adulta, como um período de moratória ou de preparação, no qual, se os dispositivos disciplinadores alcançassem o êxito, tudo correria bem e teríamos um adulto ideal capaz de ser o fundador de um novo tempo, de uma nova sociedade. Percebo que 
além da ideia do adulto ideal, é construída a própria concepção do que vem a ser o adolescente e a adolescência ou o jovem e a juventude. Mais do que diferenciar a juventude da infância e da vida adulta, a sociedade burguesa imprimiu na juventude o caráter de passageiro, imaturo e, por outro lado, período preparatório. Criou aqui uma identidade do que vem a ser o sujeito jovem.

O conceito de juventude tal qual está posto hoje é um signo construído a partir da citacionalidade ${ }^{15}$, ou seja, por meio dos signos criados através da repetição, seja ela na linguagem escrita ou oral. A citacionalidade nada mais é do que a repetição. Segundo Silva (2007), é da citacionalidade que vem a força no processo de produção da identidade. Assim, ao se repetir que juventude é quem tem entre 15 ou 29 anos, ou os atributos a ela associados, está se construindo uma identidade para o ser jovem, baseado nos ideais burgueses que sustentam o estereótipo de jovem/juventude em circulação no Brasil.

\title{
2.3 - Juventude e contornos territoriais: podem idades dizer quem eu sou?
}

\begin{abstract}
A idade, como tempo vivido pelo corpo, tem uma existência no tempo, ao longo do qual "sofremos" continuadas modificações de natureza biológica, rumo a uma degenerescência completa cujo limite para a nossa individualidade é imposto pela morte. Uma das tarefas a que se dedicou a Biologia Humana, nos últimos dois séculos, foi dividir e subdividir cronologicamente essa existência, classificando e ordenando nossos mais diferentes atributos e características - físicas, químicas, psicológicas, etc. de modo a criar faixas etárias pelas quais cada ser humano "deve" ao longo de sua vida, para ser considerado normal [...] Mas reconhecer essa dimensão biológica do tempo vivido pelo corpo muito pouco, ou quase nada, diz sobre os muitos sentidos que damos ao fato de se ter essa ou aquela idade [...] $O$ que importa é saber como essas coisas são construídas e entendidas por nós, bem como os efeitos que elas produzem sobre nós, sobre nossas vidas, sobre como as vivemos. (VEIGA-NETO, 2000, não paginado)
\end{abstract}

Cruz (2005, p. 145) contextualiza que "a juventude, tal qual a concebemos hoje, é um conceito que tem raízes numa construção discursiva que começou a ganhar os atuais contornos no final do século XIX e prosperou no século XX". Freitas (2009, p.1) complementa que "a década de 1990 vai presenciar um 'boom' discursivo nas

\footnotetext{
15 O conceito de citacionalidade remete a Jacques Derrida. De acordo com Silva (2000, p.26), trata-se "de o que caracteriza a escrita - concebida como marca ou traço material — é a possibilidade que ela tem de ser repetida ou "citada" independentemente da presença, seja do referente ou do significado, seja do emissor, ou, ainda, do receptor".
} 
produções acadêmicas sobre a temática juvenil, financiadas por fundações privadas, pelo próprio governo e por agências internacionais".

Neste boom discursivo, a juventude ganhará caráter de verdade e uma série de contornos que a limitam, e a fabricam como um território ${ }^{16}$.

Problematizo que a juventude é um território, por perceber que:

Viver e habitar em um território, além de implicar uma forma peculiar de lidar com os recursos disponíveis geograficamente, também configura laços de sociabilidade, redes de trocas e modos coletivos e singulares de produção de subjetividade. (SCISLESKI; MARASCHIN; TITTONI, 2006, p.51)

Os contornos discursivos ${ }^{17}$ do território juventude se dão a partir de diversos e múltiplos processos de subjetivação. Neste tópico, buscarei cartografar os territórios e os contornos discursivos que delimitam a juventude, ou, como expõe Groppo (2015a, p.572), "as linhas de subjetivação que atuam e os dispositivos de poder-saber que se impõem, inúmeras fontes que riscam um dado território da vida social".

Observo que um dos primeiros contornos recebidos pela juventude é o das patologias a ela associadas. Neste sentido são atribuídos à juventude enunciados associando-a com problema, imaturidade, aborrecente, rebeldes sem causa, sem responsabilidades, sexualidade precoce, potencialmente perigoso, incorrigíveis, aventureiros, entre outros. Essas características da juventude são vistas como naturais, algo imbricado na genética e peculiar desta fase, vista como universal, sendo necessário que tais singularidades patológicas sejam controladas. O controle é fomentado por uma série de dispositivos existentes no arcabouço da sociedade de controle, visando evitar que as patologias do universo juvenil possam contaminar e colocar em risco toda a população. Trata-se da biopolítica ${ }^{18}$ que age para defender a sociedade, evitando seu adoecimento conforme explicam Goulart e Santos (2009) e também Freitas (2009).

Desta forma, como sugerem Goulart e Santos:

\footnotetext{
${ }^{16}$ Território aqui é entendido como um espaço codificado, submetido a regras e controles, conforme expõe Silva (2000) e concebem Deleuze e Guattari (1997). A ideia de juventude enquanto território foi encontrada em autores como Groppo (2015a), Takeuti (2012a) e Scisleski;Maraschin e Tittoni (2006).

17 Como contornos discursivos, entendo os discursos que servem como fronteiras ao delimitar a juventude como território.

${ }_{18}$ Biopolítica designa "o que faz com que a vida e seus mecanismos entrem no domínio dos cálculos explícitos, e faz do poder-saber um agente de transformação da vida humana (FOUCAULT, 2015, p. 154).
} 
O que é interessante é que não existe uma preocupação direta com o jovem em si, mas com as taxas e índices estatísticos explicitados dentro de uma sociedade: o jovem que morre, que adoece, que rouba, só passa a ser um problema quando posto em relação a um índice demográfico, quando subsumido em uma mediação em termos globais. (GOULART; SANTOS, 2009, p.2.)

Os jovens da periferia, vistos corriqueiramente como problema, antes do boom discursivo da década de 1990, incentivados por agências internacionais ${ }^{19}$, passam a ser o alvo das políticas públicas. Neste contexto, os jovens de periferia são transportados a outros lugares com reflexo nas políticas públicas:

\begin{abstract}
Como evidencia a preocupação dessas políticas em retirarem o jovem de determinado "lugar" e localizá-lo em outro, considerando mais adequado (definido pela própria política e nunca pelos próprios sujeitos). Na mesma direção, a utilização do termo "juventudes" vai possibilitar o destravamento de uma série de dispositivos de governo das condutas dos jovens, todos eles trazendo a educação (o retorno a escola, a conclusão do nível básico ou médio de ensino, etc.) como principal articulador discursivo. (ABRAMO \& BRANCO, 2008, p.42)

Trata-se de uma ampliação do reconhecimento da multiplicidade das subjetividades juvenis? Talvez. Mas certamente aponta uma divisão problemática entre os jovens que merecem atenção, os "graus" de atenção que merecem, e aqueles que serão deixados ao largo por serem apreendidos, em linguagem foucaultiana, como "incorrigíveis". (FREITAS, 2009, p. 2)
\end{abstract}

Isso se faz necessário, pois ainda a mesma juventude que recebe contornos de problema, ainda que pareça contraditório, também recebe contornos de redentora dos problemas e anomalias visualizadas na sociedade na atualidade ou, como apresentado por Groppo (2015b, p.10), como uma "reserva vital", ou um "agente revitalizador".

Deste modo, a juventude recebe o contorno de ator estratégico do desenvolvimento. Ao receber este contorno, evita-se que a juventude assuma o contorno de problema.

Posto isso, disciplinar e controlar a juventude seriam sinônimos de construir um adulto melhor, sem as patologias presentes na atualidade, e para isso a sociedade capitalística utiliza da família, da escola, da saúde, da seguridade social, das políticas públicas que são dispositivos já expostos aqui.

O êxito destes dispositivos estaria na condição de possibilitar ao jovem seu amadurecimento, ou seja, 'tornar-se 'maiores' na medida em que participam

\footnotetext{
19 Utilizo esta expressão para designar a (ONU) e os organismos a ela vinculados como a UNESCO e a UNICEF.
} 
ativamente da vida comunitária: em defesa da ordem, em defesa da sociedade" (GOULART; SANTOS, 2009, p.1).

A preocupação não está nos jovens, mas sim nos problemas sociais que as patologias, vistas como biológicas, da juventude possam causar no conjunto social. Dessa visão, portanto:

\begin{abstract}
Surge, então, a necessidade de defender a sociedade do perigo que eles passaram a representar, movimento ilustrado pelo investimento dos jovens pelo discurso do poder: difusão do sentimento de insegurança associada a uma juventude potencialmente perigosa da qual temos e devemos ter medo, da qual precisamos nos proteger, a qual necessita também de proteção. Sua in/exclusão é pensada fundamentalmente em termos de formas sociais hegemônicas, legitimadas (normalmente alguma instância do Estado ou do mercado). (FREITAS, 2009, p.7)
\end{abstract}

Neste contorno discursivo atribuído, a juventude é mais conhecida a partir de um termo emprestado das artes cênicas: jovem protagonista. Vale lembrar que nas artes, o protagonista é a personagem principal, quem está em destaque. Neste sentido, o jovem ser protagonista significa que o jovem é o ator principal de sua história, que é construída por ele e não apenas pelos outros.

Como afirmam Goulart e Santos (2009, p.4), "o protagonista, como em toda peça de teatro ou filme, tem um papel a desempenhar, o papel de ser ator de uma transformação social". Em tese, assumindo o contorno de protagonista, o jovem agiria por si, sendo "agente do desenvolvimento", porém esta ideia de jovem protagonista é problemática, pois o protagonista, teoricamente, age de forma individual e não na coletividade, remetendo ao conceito de dobra. Até que ponto esta ação do jovem é autônoma e não engendrada e subjetivada a partir da lógica adultocêntrica ${ }^{20}$ ? Neste contorno, esses autores lembram que:

O Estado, com suas campanhas que visam à inclusão dos jovens, não
deixaria de trabalhar nos processos de subjetivação juvenis, pois o jovem
empreendedor, político, maduro e voluntário, representa uma concepção de
juventude que opera diretamente na lógica das políticas públicas de
juventude. Ao mesmo tempo, essa mesma ideia de jovem é aceita com muito
consenso em todos os movimentos políticos juvenis independentes. (2009,
p.4)

Souza (2006) complementa dizendo que na sociedade do jovem protagonista, os movimentos sociais são substituídos pela sociedade civil. E, é neste elenco

20 Termo cunhado a partir de Mayorga (2006) para explicar as fortes relações de poder entre adultos e não adultos que funcionam como dispositivos de subjetivação da identidade juvenil. 
chamado sociedade civil que o jovem é chamado a ser protagonista. Acrescenta o autor:

\begin{abstract}
Por outro lado, a emergência do enunciado protagonismo juvenil também só foi possível graças a uma concepção da sociedade e de espaço público em que indivíduos isolados - os atores sociais - encontram-se para negociar interesses. De acordo com essa concepção, o próprio indivíduo é o grande responsável pela sua inserção no mercado de trabalho, pelo acesso a serviços (e não direitos) de educação, saúde, segurança, etc., enfim, pela sua "inclusão" na sociedade. Para tanto, o indivíduo deve atuar: manter-se em atividade e em negociação com os outros atores sociais, cujo conjunto constitui a chamada sociedade civil. Assim o jovem protagonista é metaforicamente definido como o "ator principal" desse elenco da "sociedade civil" que atua num cenário considerado público. (p.62-63)
\end{abstract}

O protagonista, cunhado no palco da sociedade civil, é engendrado através da ação conjunta de agências internacionais e do Estado, que atuam como tecnologias do eu, neste processo de subjetivação:

Sem esta alma, todas estas formas de sujeição e controle sobre o comportamento dos indivíduos não seriam possíveis. É neste campo que operam as tecnologias do eu, através das quais se dá a subjetivação e permite por consequência vincular o indivíduo a uma identidade e a um poder que lhe é exterior. (FREITAS, 2009, p. 5)

Isso reforça a ideia já apresentada aqui de que o processo de subjetivação do jovem e da juventude se dá a partir de uma dobra.

Reforço aqui a importância de problematizar a construção discursiva da modernidade, e a juventude enquanto contorno discursivo de fase ou etapa de vida. Em geral, aqui a juventude é territorializada como entreposto entre a infância e a vida adulta. Desta forma:

A identidade do sujeito estaria, então, inevitavelmente atrelada à chegada a um determinado alvo: o nível de racionalidade madura. É a própria primazia da razão que produz a noção/necessidade dessa identidade do sujeito individual $e$, consequentemente, do seu desenvolvimento. (COIMBRA; BOCCO; NASCIMENTO, 2005, p.5-6)

A vida passa a ser concebida como um ciclo, com ponto de partida (infância) e um ponto de chegada (vida adulta). Nesta trajetória, as características, ou seja, as paisagens do caminho e as direções seriam sempre as mesmas, homogêneas e fixas, não importando quem por ele passe. Ou ainda, dentro da lógica capitalística apresentada por Deleuze e Guattari (1997), é como se as pessoas fossem postas em uma linha de montagem e produção, onde em cada fase elas recebem determinados atributos, a elas associados em cada etapa/fase na medida em que avançam nesta linha. No caso da juventude destaco, citando Coimbra; Bocco e Nascimento (2005, 
p.4-5), como atributos que seriam próprios de quem atravessa este caminho, ou, melhor dizendo, esta fase, atributos "como rebeldia, desinteresse, crise, instabilidade afetiva, descontentamento, melancolia, agressividade, impulsividade, entusiasmo, timidez e introspecção". Ou seja, como destaca Veiga-Neto (2000, não paginado), "não temos, a rigor, essa ou aquela idade, mas é essa ou aquela idade - isso é, aquilo que se diz dela, aquilo que se representa como idade - que nos captura, nos aprisiona e nos tem".

Porém, sem dar maior enfoque visto que este contorno foi abordado no tópico anterior, os atributos acima elencados não são exclusivos destes territórios, tampouco de quaisquer outros territórios que venham a ser criados. Desta forma, este contorno sucumbe quando encontramos em pessoas que estariam fora da fase adolescente ou juvenil, tais atributos, que, para que se impeça a sua contestação, passam a ser vistos como anomalias. Assim,

afirma-se um determinado jeito correto de ser e de estar no mundo, uma
natureza intrínseca a essa fase do desenvolvimento humano. [...] e limitado
para o jovem, uma identidade que pretende aprisioná-lo e localizá-lo,
dificultando possíveis movimentos. Ao se reafirmar a homogeneidade nega-
se a multiplicidade. (COIMBRA; BOCCO; NASCIMENTO, 2005, p.6)

Vale lembrar que, utilizando-se de dispositivos como a psicologia e a medicina, juventude e adolescência são postas no mesmo lugar, porém, no caso do Brasil, os dispositivos jurídicos, ainda que exista um período de simultaneidade, territorializam o adolescente como o sujeito que possui de 12 a 18 anos $^{21}$, enquanto o jovem seria o sujeito de 15 a 29 anos $^{22}$.

No pós-guerra, a juventude passa a ser vista dentro de uma concepção mercadológica, sendo associada ao dinamismo, à criatividade, à rebeldia e à insurreição contra a hipocrisia (DEBERT, 2010). Assim, a juventude também recebe o contorno de produto mercadológico, segundo o qual não seria definida por uma faixa etária, tampouco vista como problema, dentro desta lógica binária, mas muito pelo contrário: neste contorno são estimulados e destacados os atributos vistos como positivos da juventude. Ao ser a juventude um produto mercadológico, como todo e qualquer produto no mercado, ela está posta e pronta a ser consumida por quem quiser ou puder comprar.

21 Definido de acordo com o Estatuto da Criança e do Adolescente, Lei Federal n. ${ }^{\circ}$ 8.069/1990.

22 Definido de acordo com o Estatuto da Juventude, lei Federal n. ${ }^{\circ}$ 12.852/2013. 
Este contorno é construído por outros dispositivos, conforme destaca VeigaNeto (2000, não paginado, grifos do autor):

\begin{abstract}
Além disso, existe hoje, mais do que nunca, um poderoso arsenal de dispositivos e instituições - para citar os mais estudados: a mídia, a indústria cultural, a telemática, a escolarização de massa, o marketing político capazes de, a cada momento, criar novos marcadores ou re-significar os já existentes, reorientando constantemente os pertencimentos e os "usos" que se pode fazer desses pertencimentos. Resulta disso tudo que, mais do que em qualquer outro momento da História, vivemos numa época em que somos contínua e intensamente interpelados por marcadores identitários; vivemos numa época de proliferação das diferenças, em que os sentimentos de pertença são cambiantes e complexos, difíceis de capturar, descrever e analisar.
\end{abstract}

Destaco ainda, segundo o referido autor, que os principais dispositivos responsáveis para a territorialização da juventude como produto são a mídia, as novelas, o marketing e a propaganda, tendo em vista

\begin{abstract}
como o corpo pode ser invocado, pela mídia, a fim de não apenas informar o consumidor e promover a venda de um produto, mas também - e, nesse caso, principalmente - de construir discursivamente uma realidade (que é assumida como) verdadeira, sobre o corpo e suas idades. Essa construção discursiva funciona tanto nos ajustando ou moldando - isso é, criando novas necessidades em nós - para aquilo que um anúncio quer vender, quanto nos interpelando identitariamente - isso é, criando novos marcadores, mobilizando outros mais antigos, dizendo quem somos e quem devemos ser [...] Nesse exercício, quero chamar a atenção para o fato de que, além dos "textos verbais", os "textos imagéticos" carregam significados simbólicos.
\end{abstract}

A juventude passa de algo "dado" pela natureza, para algo "dado" pelo mercado, ou melhor, um território subjetivado pelo aparato mercadológico, ou ainda "um valor que deve ser conquistado e mantido em qualquer idade através da adoção de formas de consumo de bens e serviços apropriados" (DEBERT, 2010, p. 51). Isto é problematizado por Veiga-Neto, quando expõe:

Mas nada disso é exclusivo à mídia e à publicidade. Vários outros veículos e dispositivos nos bombardeiam sem cessar, nos constituem e nos atravessam com as mais diferentes representações. Nunca é demais relembrar as implicações éticas e políticas dessa situação. Muitas vezes contribuímos para que as mais "problemáticas" representações se combinem, se difundam e se potencializem, na medida em que nós mesmos as legitimamos a partir das posições de sujeito que ocupamos. Considero que só isso já é suficiente para que as repensemos crítica e continuamente. (2000, não paginado)

Debert destaca em sua pesquisa o caso da marca Fórum, e surpreende-se em saber que os produtos por ela fabricados para jovens e adolescentes são consumidos em sua maioria por adultecentes. Segundo Kehl (2004), neste caso, a indústria, ao produzir, busca em seus produtos transparecer o ar da juvenilidade, pois só assim 
eles despertarão o interesse destes supostos jovens perenes, contribuindo para o aumento exponencial da violência. Para essa autora:

\begin{abstract}
Poucos são aqueles capazes de consumir todos os produtos que oferecem ao adolescente contemporâneo - mas a imagem do adolescente consumidor, difundida pela publicidade e pela televisão, oferece-se à identificação, de todas as classes sociais. Assim, a cultura da sensibilidade adolescente, da busca de prazeres e novas "sensações", do desfrute do corpo, da liberdade, inclui todos os adolescentes. Do filhinho-de-papai ao morador de rua, do jovem subempregado que vive na favela ao estudante universitário do Morumbi (ou do Leblon), do traficante à patricinha, todos os adolescentes se identificam com o ideal publicitário do (a) jovem hedonista, belo (a), livre, sensual. $O$ que favorece, evidentemente, um aumento exponencial da violência entre os que se sentem incluídos pela via da imagem, mas excluídos das possibilidades de consumo. O efeito paradoxal do campo de identificações imaginárias aberto pela cultura jovem é que ele convoca pessoas de todas as idades. Quanto mais tempo pudermos nos considerar jovens hoje em dia, melhor. Melhor para a indústria de quinquilharias descartáveis, melhor para a publicidade - melhor para nós? O fato é que nas últimas décadas viramos jovens perenes. (KEHL, 2004 p.93)
\end{abstract}

Como jovens perenes, Kehl refere-se à indeterminação quanto a uma idade limite para a juventude provocada pela sua definição através de contornos mercadológicos. Porém, ainda que considere interessante sua problematização quanto aos incluídos pela imagem, mas excluídos do consumo, vejo como problemática a universalização de que todos adolescentes se identificam com o ideal de jovem engendrado pelo mercado publicitário.

Assim como exposto por Kehl sobre o jovem subjetivado pelo mercado publicitário, Debert (2010, p.57-8) relata que diferente da modernidade que operava cronologizando a vida, na pós-modernidade "a idade cronológica perde relevância, objetivando um estilo unietário".

Não se trata de relativizar a importância das idades como dispositivo de poder, mas, ao contrário, reconhecer que territórios criados a partir dele: "jovens, crianças, adultos e idosos são categorias privilegiadas na produção da moda, no vestuário, na criação de áreas específicas de saber e práticas profissionais e na definição de formas de lazer" (DEBERT, p.61). Essa autora complementa que:

Tratar das idades cronológicas é reconhecer que elas ainda são um elemento fundamental na tarefa do Estado moderno, tão bem caracterizada por Michel Foucault, de regulação do corpo social com a produção de categorias de classificação e hierarquização das populações. (p.61)

Para ela, a dissolução da vida adulta é o resultado da ideia de que a juventude é um valor que pode ser atingido a qualquer hora por aqueles que consomem fenômeno que chamo aqui de produção mercadológica -, e tem como consequência 
o alargamento das fases da vida e aos desdobramentos das fases mais avançadas da vida como a velhice - criando novas fases ou nomenclaturas (terceira idade, melhor idade). O pressuposto é o de que só atinge a fase adulta da vida quem supostamente falhou como consumidor. Associo a estes três elementos (juventude como valor, alargamento das fases da vida e desdobramentos das fases da vida) a "negação da velhice e as experiências reais que costumavam ser associadas aos idosos, como a doença e a morte" (GROPPO, 2015a, p. 570).

Até mesmo nas chamadas outras fases da vida, a juventude passa a ser perseguida, criando novas classificações etárias que no enunciado visam juvenizar a velhice, como é o caso da terceira idade ou ainda melhor idade. A vida assume, neste contorno, formas não lineares e cíclicas.

De modo geral, quaisquer que sejam os contornos atribuídos ao jovem e à juventude, esta fase é vista como natural, universal, a-histórica, fixa e rígida, sendo os jovens muitas vezes "qualificados mediante representações sobre aquilo que está faltando em seus corpos, em suas mentes e em suas linguagens" (GOULART, 2009, p.4). Concluo com as palavras de Veiga-Neto (2000, não paginado):

Quero avançar um pouco mais nessa questão, argumentando que, ao
contrário, ainda que tais atribuições (ou representações) sejam construídas
discursivamente - e, portanto, sejam culturais -, elas se dão em cima de uma
realidade muito concreta; no caso das idades, em cima de corpos biológicos
muito concretos [...] Assim, meu argumento aponta para a não suficiência dos
discursos; eles não se bastam a si mesmos, mas conectam-se
necessariamente com a materialidade do mundo.

Ainda que os contornos sejam construções discursivas engendradas por um grande aparato de dispositivos que agenciam o jovem e a juventude, é através do disciplinamento e do controle dos corpos que os discursos se materializam e se atualizam.

Encerro o capítulo assumindo a existência de outros contornos discursivos que servem como fronteiras na delimitação do território da juventude e que engendram subjetividades juvenis. Porém, a escolha pelos aqui apresentados se deve ao fato de considerá-los como os mais recorrentes na atualidade. No próximo capítulo, tratarei dos conceitos de participação e apresentarei novos contornos discursivos atribuídos à juventude no campo participativo. Nele, também abordarei o Sistema Nacional de Participação Social e as conferências nacionais, consideradas como uma "nova" forma de participação política, que serve como dispositivo produtor de juventudes. 


\section{3- CONFERÊNCIAS NACIONAIS COMO INSTÂNCIA DE PARTICIPAÇÃO}

Conforme problematizam Boghossian e Minayo (2009, p. 413), "o conceito de participação possui alta carga simbólica, sendo emblemático do contexto ideológico e da estrutura social que se compreende". Embora não seja meu objetivo esgotar ou fazer um resgate histórico sobre o conceito de participação, procuro neste capítulo lançar mão de possibilidades de análise do conceito de participação em um contexto dominado por tentativas de capturas e governamentos ${ }^{23}$ produzidos e lançados por vários focos de poder. Ao falar de governo, Castro (2009) utiliza Foucault fazendo referência a dois eixos:

Quanto à noção foucaultiana de governo, ela tem, para expressá-lo de alguma maneira, dois eixos: o governo como relação entre sujeitos e o governo como relação consigo mesmo. No primeiro sentido, "ele é um conjunto de ações sobre ações possíveis. Ele trabalha sobre um campo de possibilidade aonde vem inscrever-se o comportamento dos sujeitos que atuam: incita, induz, desvia, facilita ou dificulta, estende ou limita, torna mais ou menos provável, no limite, obriga ou impede absolutamente. Mas ele é sempre uma maneira de atuar sobre um ou vários sujeitos atuantes, e isso na medida em que atuam ou são suscetíveis de atuar. Uma ação sobre as ações." (CASTRO, 2009, p.190)

Desta forma, o conceito de governamento não se refere apenas à relação entre Estado e população, mas sim ao conjunto de dispositivos responsáveis pelo processo de subjetivação.

A implementação de mecanismos de participação atende a proposições que visam o desenvolvimento, conforme expõe Cortês (2002, p.19-20):

Durante as duas últimas décadas, nos países desenvolvidos, a institucionalização de mecanismos participatórios tem sido vista como um complemento ou como uma alternativa às formas tradicionais de representação política nas democracias liberais. No mesmo período, as agências internacionais têm preconizado que nos países em desenvolvimento sejam promovidas a auto-sustentação econômica e a participação comunitária, vistas como meios para atingir o desenvolvimento.

Vale ressaltar que a institucionalização destes mecanismos de participação só é possível em um contexto de democracia, como apresentado por Rancière:

De um lado, ouvimos por toda parte proclamar o triunfo da democracia, correlativo do desabamento dos chamados sistemas totalitários. Esse triunfo seria duplo. Seria, primeiro, uma vitória da democracia, entendida como

${ }^{23}$ Por governamento entendo uma variação da arte de governar conforme proposto por Foucault (2009, p.491), ou seja, "a maneira como a conduta de um conjunto de indivíduos viu-se implicada de forma cada vez mais acentuada no exercício do poder". Desta forma, isto não estaria restrito ao Estado. 
regime político, sistema das instituições que materializam a soberania popular, sobre seu adversário, a prova de que esse regime é ao mesmo tempo o mais justo e o mais eficaz. A falência dos chamados Estados totalitários é de fato uma falência em relação do que era sua legitimação última: o argumento de eficiência, a capacidade do sistema para fornecer as condições materiais de uma comunidade nova. Resulta daí uma legitimação reforçada do chamado regime democrático: a ideia de que ele garante num mesmo movimento as formas políticas da justiça e as formas econômicas de produção da riqueza, de composição dos juros e de otimização dos ganhos para todos. (RANCIÉRE,1996, p.99)

É sobre argumentos como estes que na democracia brasileira será engendrada a Política Nacional de Participação Social, que incorpora o proposto pelas agências internacionais, mas também o proposto pelos movimentos sociais. Problematizo os mecanismos e instâncias que podem estar legitimando e autorizando os sujeitos no que tange à participação. Foco minha atenção de aprendiz de cartógrafo para sobrevoar e pousar sobre as conferências nacionais, problematizando a ampliação de sua realização nos últimos anos, bem como as capturas e as possibilidades de potência nestes espaços vistos como de diálogo entre a sociedade civil e o poder público.

\section{1 - Possibilidades participativas: discursividades sobre a participação}

A palavra participação tem origem no latim participatiõne, e significa, de acordo com o dicionário da Língua Portuguesa da Porto Editora e o dicionário Houaiss, "ato ou efeito de participar", "envolvimento em determinada atividade". Trata-se de uma derivação da palavra participar (latim, participãre), cujo significado, de acordo com os mesmos dicionários, remete a "fazer saber", "informar", "anunciar", "comunicar", "tomar parte (em)", "intervir (em)", "associar-se pelo pensamento ou sentimento".

O desejo de participar possui uma "base afetiva - participamos porque sentimos prazer em fazer coisas com outros - e uma base instrumental - participamos porque fazer coisas com outros é mais eficaz e eficiente que fazê-las sozinhos" (BORDENAVE, 1995, p.16). Desta forma, a participação se faz presente na vida do homem desde suas origens.

Este desejo de participar e de estar com outros atua também como dispositivos responsáveis por processos de subjetivação. Como afirma Gallo (2002, p.173), "não 
há sujeitos individuais, apenas agenciamentos coletivos", e vejo na participação uma forma de agenciamento coletivo, responsável por produzir identidades, diferenças e sujeitos

Bordenave destaca que são diversos os espaços e instâncias de participação das pessoas. A família seria o primeiro espaço de participação que, como o trabalho, a escola, a comunidade e a política, atuam como tecnologias do eu, conforme referido no Capítulo 2.

Ao considerar que o homem está mergulhado em processos de participação, esse autor destaca alguns fatores positivos que acabam por estimular o desejo de participar:

\begin{abstract}
Do ponto de vista dos setores progressistas, a participação facilita o crescimento da consciência crítica da população, fortalece seu poder de reivindicação e a prepara para adquirir mais poder na sociedade... Do ponto de vista dos planejadores democráticos, a participação garante o controle das autoridades por parte do povo, visto que as lideranças centralizadas podem ser levadas facilmente à corrupção e à malversação de fundos. Quando a população participa da fiscalização dos serviços públicos, estes tendem a melhorar em qualidade e oportunidade. (BORDENAVE, 1995, p. 12-13)
\end{abstract}

Tais verdades apontadas por ele devem ser problematizadas, pois a participação não pode ser vista como algo que, quando desencadeada, produz resultados naturais e fixos. Nesse sentido, podemos questionar se o simples crescimento da participação popular seria o suficiente para possibilitar maior qualidade e oportunidade na oferta de serviços públicos.

Autores como Leon, Dolejsiová e Falangola (2009), considerando os espaços de ocorrência, classificam a participação em social, quando relacionada a associações esportivas, de bairro, escolar, filantrópica ou comunitária; política,_quando relacionadas a partido político, governos, grêmios, fóruns, conselhos, consultas; econômica, quando relacionadas ao mercado de trabalho, pagamento de impostos, economia solidária, militância em sindicatos e organizações empresariais e de empreendedores ou ainda cultural, quando empreendida com finalidade de desenvolvimento de atividades culturais, religiosas ou artísticas.

Entretanto, vale problematizar a dificuldade de classificar de forma única os tipos de participação, mesmo considerando os espaços de ocorrência ou a finalidade de participação. Questiono, por exemplo, a participação em um sindicado, que pode ser motivada por interesses financeiros, políticos ou ainda culturais, quando a atuação estiver relacionada ao desenvolvimento de atividades culturais. Neste caso, a 
motivação pode estar atrelada à dimensão econômica, porém não se aparta da dimensão política e cultural.

Guizardi (2008) ressalta que os conceitos de participação política ou social são utilizados como sinônimos. De forma complementar, autores como Teixeira, Cavalcanti e Cabral (2009) explicam as origens do termo participação, sua associação com participação política e as diferenças deste termo com participação social:

\begin{abstract}
Sintética e simplificadamente, tais argumentos podem ser apresentados da seguinte forma: a) o conceito de participação tem a idade da teoria social moderna - algo em torno de quatro séculos - como participação na polis e, pois, participação política; b) a novidade introduzida pelo "debate teórico e político" no século XX constitui em substituir o adjetivo política pelo adjetivo social, passando-se a empregar como sinônimas as expressões participação social e participação política; c) todavia, o uso clássico do conceito de participação como participação política difere do uso novo do conceito de participação como participação social porque o primeiro se refere à participação de todos os membros da polis - condição de direito (ou de dever) universal -, enquanto que o segundo se aplica a segmentos específicos da população: os pobres, os excluídos, as minorias. (TEIXEIRA; CAVALCANTI; CABRAL, 2009, p. 223)
\end{abstract}

Esta exposição, bem como o apresentado por Guizardi (2008), diverge dos conceitos de participação política e participação social apresentados por Leon, Dolejsiová e Falangola (2009). Esses autores não consideram a possibilidade do uso como sinônimo dos conceitos e restringem a análise de espaços de ocorrência, o que em tese não apresentaria as implicações do conceito apontado por Teixeira, Cavalcanti e Cabral.

Guizardi também destaca outra forma de classificar a participação levando em consideração o grau de envolvimento da população nos processos de decisão. Sobre isto, argumenta que a ligação entre política e democracia remete ao modelo de participação da Grécia Antiga, porém remodelado pós-Revolução Burguesa. As diferenças entre os modelos grego e burguês são observadas em relação ao envolvimento da população, uma vez que, como depreende Guizardi (2008, 2014), no caso grego era vista uma participação direta (democracia direta), atingindo maior percentual da população, enquanto no modelo burguês é introduzida a concepção de participação representativa (ou democracia representativa), afastando desta forma parte da população dos processos decisórios e criando uma classe política. $O$ argumento para transitar pela participação representativa em detrimento da participação direta é advogado pela 
impossibilidade de organização de uma democracia direta nas complexas sociedades modernas, fazendo com que, nos limites deste pensamento de inspiração liberal, a inserção política seja compreendida justamente como direito à representação. (GUIZARDI, 2008, p. 22)

Isto ocorre, pois, na participação representativa, cabe ao sujeito, aqui engendrado discursivamente como cidadão, a eleição de representantes nas diversas esferas e entes federados, que terão o papel de representá-lo, em tese, defendendo seu interesse.

Participação é, assim, um conceito que vai, a partir do século XIX, abrigar-se sob as teorias da democracia liberal ou sob os diferentes "modelos" de democracia. Vai ainda se traduzir prioritariamente como voto, nos entes que representam a sociedade no interior do Estado e sempre como direito universal - ou que demanda universalização - de tomar parte nas decisões que afetam o coletivo, vale dizer, como participação política. (TEIXEIRA; CAVALCANTI; CABRAL, 2009, p. 223)

Porém, este modelo tem apresentado diversas limitações, considerando que de modo geral o papel do representante tem se restringido a pedir votos e ser eleito e do representado a votar e a ouvir propostas em período eleitoral. Deste modo, as pessoas acabam se afastando das decisões, e delegando a uma classe política a tomada das decisões, "por Ihe faltarem conhecimento e informações acerca de determinado assunto, dificultando-lhes a participação e favorecendo a oligarquia" (WENDHAUSEN; CARDOSO, 2007, p. 580). Neste sentido:

\footnotetext{
O campo da representação é então batizado como prática política por excelência, força maior de expressão dos poderes "do cidadão", cujo exercício político fica dessa forma confinado num território próprio e distante de seu fazer cotidiano. A política é esvaziada de sua dimensão ontológica, tornada prática exclusiva da chamada classe política. As demais classes convertem-se, assim, em meras classes sociais. (GUIZARDI, 2014, p. 25)
}

A tensão em relação à participação representativa e à participação direta talvez esteja no desejo das pessoas de tomar parte nas decisões que as afetam diretamente, não vislumbrando nos espaços tradicionais de participação e em seus representantes eleitos potencialidades para efetuar as mudanças desejadas. Problematizo que esta tensão possa estar na potência do desejo das pessoas, ou melhor, da sociedade civil que participa, em contraposição ao desejo daqueles que as representam. Estes dois desejos fluem em velocidades e ritmos contraditórios, gerando a tensão própria das relações de poder.

De certa maneira, a participação representativa engendrada na modernidade pelo liberalismo e aprofundada pelo neoliberalismo contribuiu para a transformação 
do povo em público. Sobre a diferença de sentidos entre estes dois conceitos, Fonseca (2006, p.155) destaca que:

Se atribuímos à expressão "povo" o sentido de um conjunto de indivíduos que não apenas vivem no mesmo território, mas que estão unidos por laços e interesses comuns em relação aos quais todos são co-responsáveis, então, "público" - que aparece na frase em oposição a "povo" terá o sentido menor de um conjunto de indivíduos que são meros espectadores da vida política e social.

Com isso quero problematizar que o ato de delegar a um grupo a sua representação, como na participação representativa, acaba por transformar o povo em público, sendo que muitas vezes assumimos o papel de meros espectadores. Esse distanciamento oriundo do surgimento de uma classe política está no epicentro da tensão entre o público e a classe política.

Sobre esta relação binária com papeis bem demarcados, ao comentar Foucault, o autor referido ressalta esta produção de tensões entre as classes políticas e o público, que aqui é visto como público por ser mero destinatário das ações e serviços prestados pela classe política. Destaca ainda que:

Quanto no manifesto redigido por Foucault, no qual se denuncia o papel
menor que cabe aos indivíduos frente aos governos, sobressai o que talvez
seja um dos traços daquilo a que se pode chamar de "racionalidade política"
da arte de governar liberal - ou, mais precisamente, neoliberal - segundo o
filósofo: a saber, o sistemático afastamento dos indivíduos das esferas de
participação e de decisão política, o sistemático esvaziamento de sentido da
dimensão pública, devido a uma separação de papéis entre governos e
governados, na qual os primeiros (os governos) aparecem como os agentes
qualificados para decidir e agir, restando aos segundos (os governados) o
papel menor da simples indignação. (FONSECA, p. 156)

Ainda que tais papéis sejam repetidos na participação direta, uma vez que a execução e a transformação das proposições da sociedade civil recaem sobre os governos. A participação direta cria nos indivíduos uma sensação de maior participação e contribuição nas transformações políticas e sociais no país, quando se delega ao público a responsabilidade na tomada de decisões, ou dos possíveis sentidos atribuídos à participação.

Teixeira, Cavalcanti e Cabral compreendem o debate em torno da participação a partir da seguinte ideia:

A novidade da discussão atual sobre participação consiste no entendimento de que participar é intervir na tomada de decisões... Ou seja, não mais apenas intervir na dimensão pública da política, mas, sobretudo, intervir nas decisões que concernem à vida privada dos indivíduos: onde morar, como preservar a saúde, em que ofício trabalhar, etc. Ora, não são todos os indivíduos que 
precisam ter incrementada sua capacidade de intervir nas decisões que afetam sua vida cotidiana. Todos podem escolher representantes para o Parlamento, votar para a Presidência da República ou manifestar sua vontade em referendos ou plebiscitos. Nem todos podem, igualitariamente, preferir tal ou qual bairro para moradia, optar por determinado tipo de tratamento médico ou decidir seu futuro profissional. (TEIXEIRA; CAVALCANTI; CABRAL, 2009, p. 234)

A compreensão de participação como intervir na tomada de decisões ganhou maior notoriedade a partir da criação da Organização das Nações Unidas e da promulgação da Declaração Universal dos Direitos Humanos, em 1948, quando os sujeitos passam a ser nomeados como sujeitos de direitos, tendo, entre outros, o direito à participação (LEMOS, 2012).

Para os organismos vinculados à ONU, a participação, em especial das regiões subdesenvolvidas, é vista como uma estratégia, colocando sobre o "sujeito de direito", também nomeado como "cidadão", a função de ator estratégico do desenvolvimento (SOUZA, 2006). Cortes (1998, p.6-7) apresenta possíveis origens desta estratégia:

Durante as duas últimas décadas, nos países desenvolvidos, a
institucionalização de mecanismos participatórios tem sido vista como um
complemento ou como uma alternativa às formas tradicionais de
representação política nas democracias liberais. No mesmo período, as
agências internacionais têm preconizado que nos países em
desenvolvimento seja promovida a auto-sustentação econômica e a
participação comunitária, vistas como meios para atingir o desenvolvimento.

Cabe ressaltar que esta participação, proposta e orientada por organismos internacionais, atende a princípios neoliberais, segundo os quais a participação e a política são pensadas a partir de critérios técnicos que acabam por contribuir com o papel menor atribuído ao público, considerando sua inaptidão por não estar qualificado para este tipo de tomada de decisão, cabendo aos governos o papel maior nestes processos decisórios (FONSECA, 2006).

Uma vez que optei por considerar toda participação como política, e observando que toda participação implica relação entre sujeitos, é importante problematizar que "o poder só existe em ato; em decorrência disso só existe na relação com outro ou outros" (KLEBA; WENDAUSEN, 2009, p.737).

Ao pensar que toda participação é também uma relação de poder, acho importante problematizar o apresentado por Michel Foucault, a respeito das relações de poder. Ele não busca dizer o que é poder, definindo ou fechando um conceito, mas relata como ele atua: 
Parece-me que se deve compreender o poder, primeiro, como a multiplicidade de correlações de forças imanentes ao domínio onde se exercem e constitutivas de sua organização; o jogo que, através de lutas e afrontamentos incessantes, as transforma, reforça, inverte; os apoios que tais correlações de forças encontram umas nas outras, formando cadeias ou sistemas, ou ao contrário, as defasagens e contradições que as isolam entre si; enfim, as estratégias em que se originam e cujo esboço geral ou cristalização institucional toma corpo nos aparelhos estatais, na formulação da lei, nas hegemonias sociais. A condição de possibilidade do poder, em todo caso, o ponto de vista que permite tornar seu exercício inteligível até em seus efeitos mais "periféricos" e, também, enseja empregar seus mecanismos como chave de inteligibilidade do campo social não deve ser procurada na existência primeira de um ponto central, num foco único de soberania de onde participam formas derivadas e descendentes; é o suporte móvel das correlações de forças que, devido a sua desigualdade, induzem continuamente estados de poder, mas sempre localizados e instáveis. Onipresença do poder: não porque tenha o privilégio de agrupar tudo sob sua invencível unidade, mas porque se produz a cada instante, em todos os pontos, ou melhor, em toda relação entre um ponto e outro. O poder está em toda parte; não porque englobe tudo e sim porque provém de todos os lugares. E "o" poder, no que tem de permanente, de repetitivo, de inerte, de autorreprodutor, é apenas efeito de conjunto, esboçado a partir de todas essas mobilidades, encadeamento que se apoia em cada uma delas, em troca, procura, fixá-las. Sem dúvida, devemos ser nominalistas: o poder não é uma instituição nem uma estrutura, não é uma certa potência de que alguns sejam dotados: é o nome dado a uma situação estratégica complexa numa sociedade determinada. (FOUCAULT, 2015, p.100-101)

Penso que ao fazer tais problematizações Foucault mostra o caráter fluido, não linear e dinâmico do poder. O poder que se dá em uma relação não está concentrado em um único ponto, como em uma relação de opressor e oprimido. Ou seja, em um espaço participativo, um grupo dito como oprimido pode apoiar e defender as ideias hegemônicas. Ou ainda, em um país, um grupo que se tinha como oprimido pode ascender ao poder, e manter as relações de poder estabelecidas antes da sua ascensão.

Na obra Microfísica do Poder, Foucault contesta o caráter único e repressivo do poder reforçando como ele atravessa as relações sociais:

Ora creio ser esta uma noção negativa, estreita e esquelética do poder que curiosamente todo mundo aceitou. Se o poder fosse somente repressivo, se não fizesse outra coisa a não ser dizer não você acredita que seria obedecido? O que faz com que o poder se mantenha e que seja aceito é simplesmente que ele não pesa só como uma força que diz não, mas que de fato permeia, produz coisas, induz ao prazer, forma saber, produz discurso. Deve-se considerá-lo como uma rede produtiva que atravessa todo o corpo social muito mais do que uma instância negativa que tem por função reprimir. (FOUCAULT, 1996, p.8)

Neste bojo, no que tange à participação, Kleba e Wendausen problematizam

que: 


\begin{abstract}
A forma como os sujeitos fazem suas escolhas tem estreita relação com a capacidade de participação, mas também com a distribuição do poder nesses espaços. Assim, é preciso recriar formas de lidar com o objetivo institucional se quisermos transformar relações de poder autoritárias em relações mais horizontais que levem ao empoderamento dos atores. Isso demandaria mover relações que estão fixadas (e são assim aceitas), tornando-as flexíveis. (KLEBA, WENDAUSEN, 2009, p. 737, grifo do autor)
\end{abstract}

Tanto Foucault quanto Kleba e Wendausen ressaltam esse caráter flexível do poder, negando sua centralidade e sua localização fixa. Sobre a localização do poder, Martins e Neves (2000, p.55) também relatam a fluidez e o caráter móvel do poder ao ressaltar que ele não é privilégio do Estado, bem como "não é uma mera superestrutura, uma vez que atravessa todos os níveis da sociedade". O poder se faz presente nas relações onde existe um desequilíbrio entre os envolvidos, porém este desequilíbrio não é permanente.

As relações de poder que produzem sujeitos estão presentes, segundo Martins e Neves (2000, p.54), nos processos participativos, causando efeito paradoxal:

Sendo mais subjugados, sentimo-nos cada vez mais sujeitos, falamos cada vez mais de nós, participamos cada vez mais. Quanto maior a intimação à participação, menor a liberdade. O que acontece é a crescente improbabilidade de sermos os verdadeiros participantes da nossa própria vida: temos apenas parte activa num jogo de máscaras.

$\mathrm{O}$ ato de participar estaria, então, servindo de tecnologias do eu, atuando diretamente nos processos de subjetivação responsáveis pela constituição do eu e nas discursividades sobre participação.

Valadares (2010, p.61) ressalta que "a subjetividade, fundamentalmente privada, recôndita, reservada, introdirigida, vem se convertendo em uma subjetividade cada vez mais exteriorizada e performática". Sobre essa questão complementa:

O eu que se acreditava estar voltado ao interior de si mesmo, mantenedor de
uma suposta essência, desloca-se em direção à superfície do corpo,
conformando-se agora não mais em uma viagem introspectiva, em um
mergulho na própria subjetividade, mas na publicização de si nas telas
midiáticas. É na exteriorização que a subjetividade adquire forma e é na
performance que sua vida parece existir. Não é de se estranhar que a busca
pela visibilidade intensifica-se nos últimos tempos. Para fazer parte dos
circuitos de informação e consumo - para existir socialmente - o indivíduo
precisa da exposição ao olhar do outro. (VALADARES, 2011, p.10, grifos do
autor)

Este mesmo sujeito que é produzido e inventado através do que escreve e fala em redes sociais também se produz nos espaços formais e institucionalizados de participação, a partir do que diz, do como e quando participa. 
Quando estas relações de poder passam a atuar diretamente nos corpos tornando-os dóceis, este poder transforma-se em biopoder, o qual é engendrado quando os sujeitos são produzidos discursivamente como população. Quanto à população, Foucault (2015, p.28) discorre:

Uma das grandes novidades nas técnicas de poder, no século XVIII, foi o
surgimento da "população", como problema econômico e político: população-
riqueza, população mão de obra ou capacidade de trabalho, população em
equilíbrio entre seu crescimento próprio e as fontes de que dispõe. Os
governos percebem que não têm de lidar simplesmente com sujeitos, nem
mesmo com um "povo", porém com uma "população", com seus fenômenos
específicos e suas variáveis próprias: natalidade, morbidade, esperança de
vida, fecundidade, estado de saúde, incidência das doenças, forma de
alimentação e de habitat.

Falar de biopoder, segundo esse mesmo autor, é falar das técnicas de poder que "a partir de então vão investir sobre o corpo, a saúde, as maneiras de se alimentar e de morar, as condições de vida e todo o espaço da existência" (2015, p. 155).

Conforme o próprio Foucault, o surgimento do biopoder proporcionará o desenvolvimento do capitalismo, tendo em vista o seu caráter de produzir corpos dóceis para inserção nas linhas de produção. O biopoder vai atuar diretamente sobre os corpos dos indivíduos que deixaram de ser indivíduos para tornarem-se população a ser controlada por uma série de dispositivos da biopolítica, responsáveis pela construção dos corpos dóceis como é o caso da medicina, da pedagogia, da família e de tantos outros que contribuirão com o aparato estatal para controlar natalidade, mortalidade, expectativa de vida e demais fenômenos vistos como próprios e confluentes das populações.

O objetivo de controlar as populações está na seguridade de garantir os processos produtivos, tendo em vista que qualquer problema neste grupo pode comprometer a cadeia e esses processos.

Os conceitos de biopoder, biopolítica e população são importantes para esta pesquisa, considerando que a participação se transforma em um dispositivo produtor de populações. São importantes também por acreditar que é a partir dos agrupamentos populacionais - como a juventude, as mulheres, os negros, ou seja, grupos com características populacionais engendradas para homogeneizar os sujeitos em determinados segmentos - que somos instigados a participar. É por meio destes agrupamentos que são atribuídas a nós legitimidade e autoridade para participar em determinados espaços em detrimento de outros. A partir do momento que se é rotulado em um grupo populacional, determinadas características nossas 
passam a ser esperadas, ou mesmo de nosso corpo reverberando na vida em um campo de disputa, do qual o biopoder e a biopolítica ${ }^{24}$ se ocupam. São os ditos e interditos agindo sobre os espaços e as possibilidades de participação.

Desta forma, os agrupamentos populacionais passam também a servir como dispositivos disciplinadores e de controle, sendo o sujeito moderno "submetido e forjado por tecnologias disciplinares essenciais à construção de um homem 'organismo', 'indivíduo' e 'função', medido e julgado em sua adequação à norma, à normalidade instaurada" (GUIZARDI, 2014, p. 30).

Contudo, tais determinações não ocorrem de forma pacífica. Assim como toda participação é uma relação de poder, elas também implicam a existência de resistências. Como apresenta Foucault (2015, p. 104), "lá onde há poder há resistência", reforçando as correlações de força tensas e em desequilíbrio que são as relações de poder. Como resistência, utilizo o conceito cunhado por Foucault:

Portanto, não existe, com respeito ao poder, um lugar de grande Recusa -
alma da revolta, foco de todas as rebeliões, lei pura do revolucionário. Mas
sim resistências, no plural, que são casos únicos: possíveis, necessárias,
improváveis, espontâneas, selvagens, solitárias, planejadas, arrastadas,
violentas, irreconciliáveis, prontas ao compromisso, interessadas ou fadadas
ao sacrifício; por definição, não podem existir a não ser no campo estratégico
das relações de poder. Mas isso não quer dizer que sejam apenas subproduto
das mesmas, sua marca em negativo, formando, por oposição à dominação
essencial, um reverso inteiramente passivo, fadado à infinita derrota. As
resistências não se reduzem a uns poucos princípios heterogêneos; mas não
é por isso que sejam ilusão, ou promessa necessariamente desrespeitada.
Elas são o outro termo nas relações de poder; inscrevem-se nessas relações
como o interlocutor irredutível. Também são distribuídas de modo irregular:
os pontos, os nós, os focos de resistência disseminam-se com mais ou menos
densidade no tempo e no espaço, às vezes provocando levante de grupos ou
indivíduos de maneira definitiva, inflamando certos pontos do corpo, certos
momentos da vida, certos tipos de comportamento. (p.104-105)

Kleba e Wendausen (2009, p. 737) reforçam que as "resistências acontecem cotidianamente, mas não temos consciência plena de sua existência e da força que possuem". Na participação, a resistência pode surgir, como observado por Martins e Neves (2000, p. 61), como "um catalizador químico, que permita colocar em evidência as relações de poder, ver onde elas se inscrevem, descobrir os seus pontos de aplicação e os métodos que utilizam".

As resistências surgem no embate entre o que está normatizado, inclusive no campo da participação, quando somos praticamente intimados a participar, ou quando

${ }^{24}$ Designa "o que faz com que a vida e seus mecanismos entrem no domínio dos cálculos explícitos, e faz do poder-saber um agente de transformação da vida humana" (FOUCAULT, 2015, p. 154). 
são normatizados os lugares, os jeitos e as formas de participar, forjando a partir de então participação maior ${ }^{25}$ ou participação menor.

Para encontrar outras possibilidades, recorro ao conceito de participação rizomática apresentado por Quintanilha e Dalbello-Araujo (2014), que a engendram a partir do conceito de rizoma ${ }^{26}$ pensado por Deleuze e Guatari (2000). Por conseguinte:

\begin{abstract}
As características da participação rizomática se assemelham ao rizoma, que... é um aglomerado de caules no qual não se sabe exatamente o lugar de origem de cada ramo nem onde irá terminar, visto que os filamentos se esbarram e se cruzam em diversos pontos, assim como os movimentos de resistências, cuja culminância não se sabe precisar. A participação rizomática se caracteriza, então, por não ter uma forma preestabelecida de existência ou ocorrência, podendo emergir como movimentos de resistência, nos quais ganha forma, corpo e pode ser percebida [...] A participação rizomática se apresenta, portanto, como uma linha de fuga em meio ao processo institucionalizado no qual a participação social está inserida. Ela escapa às regras e normas impostas de funcionamento... (QUINTANILHA; DALBELLOARAUJO, 2014, p.100)
\end{abstract}

Utilizo este conceito, ainda que não de forma definitiva ou acabada, por acreditar que toda participação é política e social. Também, por observar que mesmo em espaços institucionalizados de participação como conselhos, conferências, grêmios estudantis, sindicatos, etc., sempre existe algo que escapa ao espaço estriado. É o espaço liso se fazendo presente no espaço estriado e produzindo devir e potência na vida e nos espaços participativos:

\begin{abstract}
Atualmente, mediante esse novo funcionamento do corpo social, a resistência não se liga somente à oposição direta do campo de forças descrito acima, mas também e, sobretudo, à produção de dispositivos singulares que não estejam a serviço da serialização instituída. Isso porque a força-invenção da vida não se encontra totalmente capturada pelo capital, pois é exatamente no que o poder investe que também se ancora sua resistência. Sem dúvida, a vida é em si uma potência, que funda e dispara singularidades. E o agenciamento com essa força intensiva conduz à resistência, à invenção. (ROMAGNOLI et al., 2009, p. 200)
\end{abstract}

A participação rizomática é assim a participação que, mesmo dentro de espaços como as conferências, foco desta pesquisa, ou mesmo dentro do sistema e

\footnotetext{
${ }^{25}$ Por participação maior compreendo algumas formas de participação que são mais valorizadas, como apresentam Butler e Princeswal (2012), como a participação em partidos políticos, ONGs, movimento estudantil. E por participação menor, aquelas que são preteridas, em especial oriundas de práticas culturais próprias da periferia.

26 "Um rizoma como haste subterrânea distingue-se absolutamente das raízes e radículas",pois qualquer ponto de um rizoma pode ser conectado a qualquer outro e deve sê-lo. É muito diferente da árvore ou da raiz que fixam um ponto, uma ordem (DELEUZE, GUATTARI, 2000, p. 14).
} 
da política nacional de participação social, que serão abordados a seguir, surge como potência e resistência ao que está posto e instituído.

Nesta pesquisa, reconhecendo as possibilidades criadas nos espaços de participação direta e participação representativa, adotarei o conceito de participação rizomática, não diferindo ou criando "compartimentos participativos", por pensar e compreender que, quando falamos de participação, toda participação é política, ancorado na ideia de Arendt (2004, p. 21): "a política trata da convivência entre diferentes". E, também, como problematiza Gallo (2002, p. 172) ao nos apresentar a concepção de educação menor ${ }^{27}$, "o próprio ato de existir é um ato político, revolucionário: um desafio ao sistema instituído", e por compartilhar da ideia apresentada por Guizardi.

\begin{abstract}
Pensar a constituição política da vida social apenas no campo dos mecanismos de representação equivale a objetivar os homens em suas relações de coexistência e de produção de si e do mundo. Não que seja desejável ou necessário eliminar tais artefatos políticos, que hoje prevalecem em nossas sociedades. Interrogamos apenas se os mesmos serão efetivos em expressar o plano político da existência humana se permanecerem atuando como fator de segregação entre a política e a vida social, o que remete diretamente às instituições e às relações de poder que as organizam e perpetuam. (GUIZARDI, 2014, p. 35)
\end{abstract}

Desta forma, e compartilhando o que pensa Michel Senellart (2008, p.535), ao citar Foucault, "nada é político, tudo é politizável, tudo pode se tornar político. A política não é nada mais nada menos do que o que nasce com a resistência à governamentabilidade, a primeira sublevação, o primeiro enfrentamento", que nasce do desejo e da necessidade de relacionar-se com o outro, que por si só já se traduz como um ato político, social e cultural.

Prosseguindo, a partir das problematizações feitas sobre as discursividades em torno de participação, abordarei a institucionalização da mesma no Brasil. Esta se deu com a criação da Política Nacional de Participação Social, a qual, com base na CF1988 e no proposto em documentos de agências internacionais, passou a ser concebida como um direito fundamental a ser garantido pelo Estado a partir da instituição de espaços participativos regulamentados e normatizados através de leis e decretos.

${ }^{27}$ Como o próprio Gallo (2002) expõe, o conceito de educação menor é um deslocamento do conceito de literatura menor, apresentado por Deleuze. 


\title{
3.2- A Política Nacional de Participação Social e o Sistema Nacional de Participação Social
}

Todo o poder emana do povo, que o exerce por meio de representantes eleitos ou diretamente, nos termos desta Constituição (Brasil, 1988).

É esta premissa, comum em estados seculares, que embasa a Política Nacional de Participação Social (PNPS) instituída por meio do decreto presidencial n. ${ }^{\circ}$ 8243/201428. Juridicamente apresentada em 2014, a PNPS foi instituída em 2007, mas, segundo Lígia Maria Alves, ex-coordenadora geral de participação social da gestão pública da extinta Secretaria-Geral da Presidência da República, foi no governo Dilma que ganhou mais força, conforme explica:

\begin{abstract}
O governo foi dividido em quatro grandes áreas e, uma delas, foi Direito e Cidadania. A partir daí, foi criado um Fórum de Direito e Cidadania e, dentro desse Fórum, nós começamos a trabalhar participação social como um direito. Nós então chegamos à conclusão de que precisávamos discutir uma política de participação social. Eu me lembro bem de uma fala do professor Leonardo Avritzer: "O Brasil não tem sistema Nacional de Participação, o Brasil só tem momentos participativos". E isso ficou muito na minha mente. (DEMOCRACIA, JUSTIÇA E CONTROLE PÚBLICO, 2013).
\end{abstract}

De acordo com a Secretaria-Geral da Presidência da República pode-se definir a Política Nacional de participação social como a responsável por definir

\begin{abstract}
os objetivos que afetarão a gestão governamental como um todo, explicitando os princípios e diretrizes a serem observados pelo Sistema Nacional de Participação Social. A Política Nacional estabelece o papel do Estado como agente promotor do direito humano à participação. Diretamente, estará voltada ao governo federal (administração pública direta e indireta), mas indiretamente (por fomento e articulação) pretende alcançar estados, municípios, entidades e movimentos sociais que, no âmbito de sua autonomia, optarem em integrar o Sistema Nacional. (BRASIL, 2013)
\end{abstract}

A PNPS, segundo o decreto n. ${ }^{\circ}$ 8243/2014, tem por objetivo "fortalecer e articular os mecanismos e as instâncias democráticas de diálogo e a atuação conjunta entre a administração pública federal e a sociedade civil". Em suma, muitos dispositivos que foram definidos, no sentido literal através do decreto mencionado, já estavam em prática desde a democratização e, no caso das conferências, desde a era Vargas. Porém, sua regulamentação através de um decreto possibilitou a explicitação de seu formato, diretrizes e objetivos.

${ }^{28}$ Para ler o decreto na integra vide Anexo A. 
Considerando que a Constituição Federal de 1988 foi intitulada "Constituição Cidadã", de acordo com Silva (2009, p.14), por "ter incluído em seu âmbito mecanismos de participação no processo decisório federal e local", a instituição da PNPS e do Sistema Nacional de Participação Social (SNPS) vem reforçar o "reconhecimento da participação social como direito do cidadão" (BRASIL, 2014), definindo, entre outros já existentes, os conselhos de políticas públicas, as comissões de políticas públicas, as conferências nacionais, a ouvidoria pública federal, as mesas de diálogo, os fóruns interconselhos, as audiências públicas, as consultas públicas e os ambientes virtuais de participação social como instâncias e mecanismos de participação. Saliento que, exceto os ambientes virtuais de participação, muitos destes mecanismos e instâncias já estavam em funcionamento, antes mesmo do decreto ou da institucionalização da PNPS. Acredito que o papel do decreto se resume em normatizar cada um destes espaços, conferindo a eles diretrizes básicas para seu funcionamento e, também, reconhecer a participação como um direito fundamental do cidadão a ser garantido pelo Estado.

Como ambientes virtuais de participação foram lançados pelo governo federal o Participa.br e o Dialoga Brasil. O Dialoga Brasil foi lançado em julho de 2015, logo após as manifestações que pediam o impeachment da presidente Dilma Rousseff. Vejo esta ferramenta como uma estratégia na tentativa de aproximação do governo federal com a sociedade civil. O Dialoga Brasil:

É uma plataforma de participação digital em que o usuário poderá elaborar e
apoiar propostas para ajudar a melhorar os programas do governo. Pela
ferramenta, é possível fazer sugestões, curtir propostas de outros
participantes, conhecer as principais políticas do governo. (BRASIL.
SECRETARIA DE GOVERNO, 201529)

Já o Participa.br, que foi lançado juntamente com o decreto da PNPS é uma ferramenta digital e como tal:

A plataforma oferece uma série de ferramentas de comunicação para cidadãos, redes, movimentos sociais e organizações que querem participar com o Governo Federal na construção de políticas públicas. O Participa.br permite a proposição de temas em espaço de publicações da própria ferramenta e facilita a criação de iniciativas de diálogo e construção de políticas públicas com a sociedade. (BRASIL.SERPRO, 20140)

\footnotetext{
29 Disponível em: <http://www.secretariageral.gov.br/noticias/2015/julho/29-07-2015-presidenta-dilmalanca-plataforma-de-participacao-dialoga-brasil>. Acesso em: 12.12.2015.

30 Disponível em: < http://www.serpro.gov.br/linhas-negocio/catalogo-de-solucoes/solucoes/outrassolucoes/participa-br-plataforma-federal-da-participacao-social>. Acesso em 12.12.2015.
} 
Enquanto no Participa.br o usuário tem maior possibilidade de interação, podendo participar de consultas abertas, propor e sugerir temas, e buscar apoio para suas propostas através das redes sociais, o Dialoga Brasil apenas permite ao usuário avaliar e tecer comentários acerca de consultas disponibilizadas pelo governo federal.

Todos os mecanismos e instâncias segmentam de forma binária os participantes em sociedade civil e poder público, cabendo prioritariamente, para não utilizar o termo exclusivamente, ao segundo, a convocação ou o chamamento da sociedade civil para o diálogo.

Assim, os mecanismos e instâncias de participação governamentais podem ser definidos como formas ou possibilidades de diálogo entre a sociedade civil e o poder público que visam ao estímulo à participação da sociedade civil nos processos decisórios do governo em todos os entes federados, porém este diálogo é quase sempre disparado pelo poder público.

Quando publicado, o decreto causou, no ano de 2014, grande repercussão no cenário nacional, no que tange aos veículos de comunicação, redes sociais e no congresso nacional. Os setores de oposição ao governo o taxaram de "bolivariano" e "antidemocrático", uma vez que para eles a presidente Dilma Rousseff queria mudar, por decreto, o sistema político brasileiro.

A reação dos deputados oposicionistas foi imediata, e, após quatro dias da publicação do decreto presidencial, foi apresentado pelos deputados Mendonça Filho $(\mathrm{DEM} / \mathrm{PE})$ e Ronaldo Caiado (DEM/GO) ${ }^{31}$ projeto de decreto legislativo n. ${ }^{\circ}$ $1491 / 2014^{32}$ com o objetivo de sustar os efeitos do decreto presidencial, sendo o mesmo aprovado na Câmara dos Deputados em 29 de outubro de 2014, dois dias após findar o segundo turno da eleição presidencial.

Entre os motivos utilizados pelos deputados, em sua justificativa, está o questionamento do conceito de sociedade civil definida no decreto presidencial como "o cidadão, os coletivos, os movimentos sociais institucionalizados ou não institucionalizados, suas redes e suas organizações" (BRASIL, 2014, Art.2 ${ }^{\circ}$, inciso I). Entendo que o decreto versa sobre sociedade civil em sentido amplo próximo ao exposto por Souza (2006), normatizado como algo amplo, para além dos movimentos sociais organizados, considerando aqui inclusive as ONGs e o sujeito enquanto

\footnotetext{
${ }^{31}$ A referência ao cargo eletivo ocupado por Mendonça Filho e Ronaldo Caiado refere-se à legislatura de 2011-2015.

${ }^{32}$ Para ler o PDC na integra vide Anexo B.
} 
indivíduo, sem a necessidade de estar atrelado a um grupo ou coletivo de participação. Porém, para Ronaldo Caiado e Mendonça Filho, ao definir sociedade civil, a presidente estaria restringindo a participação popular, impedindo os cidadãos não vinculados a movimentos sociais de participar, ficando relegados a segundo plano, contrariando a Constituição Federal (BRASIL, CÂMARA, 2014).

Outro argumento apresentado pelos deputados faz referência ao interesse da presidente em reduzir o poder e o papel designado pela CF-88 ao Congresso Nacional. Conforme Projeto de Decreto Legislativo n. ${ }^{0} 1491 / 2014$ dos senhores Mendonça Filho e Ronaldo Caiado:

Essas breves linhas retratam de maneira absolutamente clara qual a intenção
da Presidente da República: implodir o regime de democracia representativa,
na medida em que tende a transformar esta Casa em um autêntico elefante
branco, mediante a transferência do debate institucional para segmentos
eventualmente cooptados pelo próprio Governo. O ato em questão não
comporta outra leitura. Especialmente, levando-se em conta que a Carta da
República já disponibiliza os instrumentos que asseguram a participação de
qualquer cidadão brasileiro nas decisões políticas. (CÂMARA DOS
DEPUTADOS, 2014)

Ao se referir aos instrumentos de participação popular, os deputados se reportam ao plebiscito, referendo e iniciativa popular, previstos no Artigo 14 da CF-88.

Desde novembro de 2014, o projeto encontra-se em tramitação no Senado Federal (PDC-SF n. $\left.{ }^{0} 147 / 14\right)^{33}$ e, apesar de estar pronto para pauta, ainda não foi à votação no Senado Federal, continuando o decreto em vigor.

Observo no relato sobre o Decreto Presidencial n. ${ }^{\circ}$ 8243/2014 uma tensão entre aqueles que possuem o poder através da participação representativa e vislumbram a redução desses poderes que podem ser reduzidos pelo crescimento dos mecanismos e instâncias de participação direta. Resumindo, para alguns congressistas, o poder emana do povo, desde que não seja uma ameaça ao poder conferido aos congressistas pelo direito de voto.

Creio ser interessante problematizar também as discursividades construídas a partir da participação na constituição federal. Posto que, para a situação, no governo federal a participação direta é vista como uma forma de legitimar ações do governo, enquanto para os setores oposicionistas a mesma é vista como uma tentativa do partido, que está no governo federal, de aparelhar a administração pública através de movimentos sociais que a esta servem de sustentação.

33 Para ler o PDC-SF na integra vide Anexo C. 
Retomando os sentidos e significados da PNPS e do SNPS, observo que tanto em suas cartilhas de orientação ${ }^{34}$, quanto no decreto que a institui não existe uma definição explícita do que vem a ser participação social. Contudo, observando o já exposto no tópico anterior, penso que a expressão "participação social" em ambos é usada no mesmo sentido da expressão "participação política", dentro do apresentado por Guizardi (2008), como sinônimos. Conjuntamente, a participação social é vista como o envolvimento por parte dos cidadãos nos processos decisórios da definição, planejamento, execução e fiscalização das políticas públicas.

Pondero que, a partir da institucionalização da participação social por decreto, o conceito de participação passa a ter sentido de envolver-se nos processos decisórios, aceitando as diretrizes do que é instituído e normatizado em cada um dos mecanismos e instâncias participativas (SOUZA, 2006). Porém, apesar das capturas presentes neste processo, não podemos desprezar, e isto será mais bem tecido no Capítulo 6, que tais apreensões e normatizações geram potência e resistência, não concentrando o poder em um único ponto, estando as tensões presentes a todo momento.

Materializada através de decreto, a PNPS e o SNPS visam fomentar a participação não apenas na esfera federal, mas também desencadear um processo articulado em todos os entes federados ${ }^{35}$. Por isso a opção pela nomenclatura de "Sistema Nacional", cuja responsabilidade de coordenação ficou a cargo da Secretaria-Geral da Presidência da República, extinta através da Medida Provisória (MPV) n. ${ }^{\circ}$ 696/2015 que reduziu o número de ministérios, e desde então não possui nova designação de coordenação.

A promoção é da participação social através da PNPS e mostra, além do reconhecimento e institucionalização da participação como direito do cidadão, a opção dos governos Lula e Dilma por transformá-la em uma política de governo, ganhando, através da edição de um decreto, uma tentativa de transformá-la em política de Estado, não apenas no incentivo, mas também na criação de canais de participação, no financiamento das atividades, por parte do Estado. Trata-se de uma política que visa envolver e fomentar a participação da sociedade civil na definição da agenda das políticas públicas.

\footnotetext{
34 Vide Anexo D.

35 União, Estados e Municípios.
} 
Aqui observo que, conforme problematizado por Souza, a população, também nomeada de sujeito de direito e cidadão, converte-se em ator social, que deve ser protagonista através de participação ativa na sociedade civil. A partir dessa conceituação:

De maneira geral, a expressão ator social refere-se, hoje em dia, àquele que trabalha pela consecução de objetivos pessoais numa dada conjuntura social e, por extensão, àquele que trabalha pela resolução de seus próprios problemas e daqueles que afetam a coletividade. Essa atividade do ator social, em prol de si mesmo e do grupo social, é o que faz dele um membro da sociedade civil. (SOUZA, 2006, p. 63)

A lógica da PNPS e do SNPS busca transformar a população em ator social: "aquele que, para conseguir alcançar objetivos particulares, modifica o 'entorno social' negociando com outros atores" (SOUZA, p.64). Este modificar o entorno social é ter participação ativa, ou seja, ter atuação direta na "construção, o que é feito através da tomada de decisões e das atividades sociais em todos os níveis" (BORDENAVE, 1995, p.20).

Cortes (1998. p. 6-7) salienta que "as agências internacionais têm preconizado que nos países em desenvolvimento seja promovida a autossustentação econômica e a participação comunitárias, vistas como meios para atingir o desenvolvimento". Em suma, o discurso apresentado por organismos internacionais, conforme problematizam Lemos (2012) e Souza (2006) sobre a importância, em especial em países em desenvolvimento, da implementação da participação, passa a ser compartilhado pelo governo federal brasileiro e reverberado por movimentos sociais, coletivos ou, melhor dizendo, por parte da sociedade civil. Nesse sentido, Lemos indaga:

\footnotetext{
Mas podemos nos perguntar se os Estados apenas obedecem a estes parâmetros, mesmo quando os ratificam e dizem que irão segui-los, ou ainda podemos nos perguntar se os projetos e programas financiados e assessorados por estas agências são executados tal como foi estabelecido nos tratados e contratos realizados. Ou podemos também pensar e indagar se a população-alvo destas políticas apenas aceita o lugar de vítima e de passividade receptiva de políticas compensatórias prescrito por estes projetos e programas. (LEMOS, 2012, p. 58)
}

Ao institucionalizar a participação a partir de mecanismos e instâncias, estas adquirem o papel de tecnologias do eu que, através da biopolítica, "formam, acima de tudo, modalidades de captura e submissão do corpo às forças produtivas" (NESPOLI, 2014, p.62). 
Neste processo de institucionalização da participação, acredito que alguns cuidados devem ser tomados no que concerne ao governo, que visa, segundo os documentos oficiais, ouvir e dialogar com a população e a sociedade civil, a quem cabe falar e participar:

- Participação como captura: A opção do Governo Federal em instituir e garantir a participação como direito é uma atitude que possibilita potências na relação entre sociedade civil e poder público. Porém, ao mesmo tempo em que assegura a participação a partir de dispositivos mínimos para sua efetivação, o Estado Brasileiro também captura e normatiza a participação, que em tese deveria ser uma ação cujo mecanismo disparador deveria ser o desejo da população. Sobre isto Bordenave (1995, p.14) destaca que a instrumentalização da participação, que aqui prefiro chamar de captura ${ }^{36}$, leva ao "perigo de que se veja nela algo para ser dirigido, manipulado ou explorado quanto a seus resultados utilitários". Ou ainda, como apresentam Wendhausen e Caponi (2002, p. 1625), "o uso instrumental de um espaço que se pretendia 'democrático', para legitimar ações governamentais e não para 'controlá-las' e “avaliá-las”. Estas possibilidades de captura já são notadas no que tange à participação em sindicatos e alguns movimentos sociais no relatado por Mendonça Filho e Ronaldo Caiado, ao apresentarem o PDC de sustação do decreto presidencial.

- PNPS como participação maior: Quando Gallo (2002, p. 174) propõe os conceitos de educação maior e educação menor, ele explica que a educação maior, através de suas diretrizes, está "sempre a nos dizer o que ensinar, como ensinar, para quem ensinar, porque ensinar" e que sempre "procura constituirse como uma imensa máquina de controle, uma máquina de subjetivação, de produção de indivíduos em série”. A educação maior é a educação instituída e normatizada através dos documentos institucionais. Já a educação menor "é um ato de revolta e de resistência às políticas impostas" (GALLO, 2002, p. 173). Com estas ideias apresentadas por esse autor, acredito que é possível, assim como ele, deslocar os conceitos de Deleuze - da literatura para a

\footnotetext{
36 Opto por utilizar o termo captura em virtude de achar que a ideia de instrumentalização remete a uma relação de poder mais binária, sendo captura mais coerente com o referencial teórico que utilizo. Ao referir à captura estou analisando como a institucionalização de espaços pode levar à fixação de espaços participativos, muitas vezes deslegitimando o devir criativo dos sujeitos ao propor novos espaços e novas formas de participação.
} 
educação - também para a participação. Desta forma, o risco iminente, a partir da institucionalização da PNPS, é a criação de uma participação maior, com a supervalorização dos mecanismos e instâncias de participação social, em detrimento de outros. Deste modo, teríamos a negação da participação menor, enquanto a participação maior estaria a nos dizer como, onde e quando participar. Por outro lado, ainda que isso ocorra, a participação maior estará a produzir resistências e a criar possibilidades.

- Despotencialização dos instrumentos e mecanismos do SNPS: Em qualquer diálogo, quando somos chamados a falar, existe em nós a expectativa de sermos ouvidos. Com a crescente realização dos instrumentos e mecanismos do SNPS, muitas vezes em curto espaço de tempo, ocorre que o poder público pode não executar, ou ainda ignorar o apontado nestes processos dialógicos. Isso poderia levar o SNPS ao descrédito, uma vez que, chamado para o diálogo, não responde como esperado.

A seguir, considerando que dentre as instâncias e mecanismos da Política Nacional de Participação Social (PNPS) as conferências nacionais são o objeto deste estudo, problematizarei questões referentes a sua institucionalização, sentidos e significados, partindo do resgate do início de sua prática no Brasil.

\section{3- Conferências Nacionais como forma de participação social: surgimento, recorrência e institucionalização ${ }^{37}$}

Observando que os mecanismos de participação representativa têm apresentado limites, uma vez que este "espaço público não é vivido como território aberto à produção de realidade social, mas como espaço de sua regulação, de sua contenção, enredado em redes hierárquicas e institucionais de ordenamento social" (GUIZARDI, 2009, p.15), as conferências surgem como possibilidade de participação direta na superação destes obstáculos.

As conferências nacionais despontam como espaços instituídos, criados em 1940, durante o Estado Novo de Getúlio Vargas, dentro da perspectiva de ampliar a participação popular sobre as políticas públicas a serem implementadas pelo Estado.

37 Utilizo o termo institucionalização para designar o processo de efetivação da realização das conferências por dispositivos jurídicos (leis, decretos, portaria interministerial). 
O trecho da lei abaixo, do ano de 1937, nos mostra o ato da convocação da primeira conferência nacional, narrando também as suas motivações:

Art. 90. Ficam instituídas a Conferência Nacional de Educação e a Conferência Nacional de Saúde, destinadas a facilitar ao Governo Federal o conhecimento das actividades concernentes à educação e à saúde, realizadas em todo o Paiz, e a orientá-lo na execução dos serviços locaes de educação e de saúde, bem como na concessão do auxílio e da subvenção federaes. (Lei n. ${ }^{\circ}$ 378/1937)

Apesar do exposto na lei, e reafirmado por Horta (2000) e Hochmann (2005), não encontrei indícios da realização, naquele ano, da Conferência Nacional de Educação. Desta forma e com base em informações expostas no site ${ }^{38}$ da SecretariaGeral da Presidência da República, considero como primeira Conferência Nacional realizada no Brasil a Conferência Nacional de Saúde, ocorrida em 1941, no município do Rio de Janeiro, então capital federal.

De acordo com Gustavo Capanema, então Ministro da Educação e Saúde Pública, responsável por solicitar a convocação da primeira conferência, o objetivo era o alinhamento entre as demandas e necessidades da população e as políticas públicas implementadas em todas as esferas governamentais:

O considerável desenvolvimento das atividades federais em matéria de educação e saúde, a magnitude dos empreendimentos projetados, a necessidade de que para esses empreendimentos concorram os governos estaduais e municipais, com trabalhos e recursos, tudo está à mostra à conveniência da imediata convocação das citadas conferências nacionais. (Brasil, 1941, p.5)

A partir de então, passados 74 anos da realização da primeira Conferência Nacional, aconteceram 143 conferências em território nacional ${ }^{39}$, conforme exponho na tabela abaixo:

Tabela 2 - Conferências realizadas por período

\begin{tabular}{|c|c|c|}
\hline Período & Governos & Total de conferências \\
\hline $1941-1964$ & Estado Novo a Jango & 3 \\
\hline $1964-1985$ & Ditadura Militar & 4 \\
\hline $1985-1990$ & Sarney & 7 \\
\hline $1990-1994$ & Collor/ltamar & 8 \\
\hline $1995-2002$ & FHC & 74 \\
\hline $2003-2010$ & Lula & 28 \\
\hline $2010-2015$ & Dilma & $\mathbf{1 4 3}$ \\
\hline \multicolumn{2}{|c|}{ Total } \\
\hline
\end{tabular}

Fonte: Adaptado de Brasil (2014), Secretaria de Governo 40

38 Disponível em: <http://www.secretariageral.gov.br/participacao-social/conferencias/conferencias2011-2014.pdf>. Acesso em: 25 dez.2015.

39 Para ver a relação de conferências nacionais realizadas por tema e ano vide Anexo E.

40 Disponível em< http://www.secretariageral.gov.br/participacao-social/conferencias/conferenciasnacionais-grafico-1941-2013/view> e < http://www.participa.br/portal/blog/calendario-das-conferencias 
Apesar de realizada pela primeira vez na década de 1940, as conferências foram, por muitas décadas, pouco utilizadas como instrumentos de participação, tendo seu boom de realização a partir de 2003, no governo Lula. É possível observar que:

Apesar de existirem antes do governo Lula, é em seu governo que as
conferências passam a ser realizadas de forma mais ampla, uma vez que até
então estavam restritas à área da saúde e assistência social. (Avritzer, 2012,
p. 7)

No período compreendido entre os governos de Getúlio Vargas, no Estado Novo, até o governo de João Goulart (Jango), bem como durante a Ditadura Militar, as conferências realizadas estavam restritas à área da saúde.

A mudança verificada ao longo dos governos José Sarney e Collor/ltamar Franco foi a realização de conferências ainda na área da saúde, porém com subtemáticas ${ }^{41}$. José Sarney foi também o responsável pela realização de Conferência de Ciência, Tecnologia e Inovação.

Durante os governos de Fernando Henrique Cardoso (FHC), para além da temática da saúde (incluindo subtemáticas) e de Ciência, Tecnologia e Inovação, foram acrescidas as temáticas de Assistência Social, Direitos Humanos e dos Direitos da Criança e do Adolescente. Na era FHC as conferências de Direitos Humanos foram realizadas anualmente de 1996 a 2002, enquanto que a Conferência dos Direitos da Criança e do Adolescente ocorreram em quatro edições bianuais de 1995 a 2001.

O governo do presidente Luiz Inácio Lula da Silva foi o período em que ocorreu o maior número de conferências nacionais, além de ampliação considerável das temáticas. Foram acrescentados temas versando sobre direitos de grupos, ditos minoritários, por recortes etários, uso do território. Pinto (2009) destaca que nos governos anteriores os temas eram restritos àqueles com exigência legal, como saúde e assistência social.

Pinto (2009, p. 5) ressalta também, ao comparar os governos FHC e Lula, que FHC teria agregado novos temas, porém "não são resultados de questões nascidas nos movimentos sociais ou nos movimento de base popular", que contavam com

\footnotetext{
41 Além da Conferência Nacional de Saúde foram realizadas também as Conferências Nacionais de Gestão do Trabalho e da Educação na Saúde, de Saúde Bucal, de Saúde do Trabalhador, de Saúde Indígena e, por fim, de Saúde Mental. Nos governos Collor/ Itamar foram realizadas também Conferências de Segurança Alimentar e Nutricional e Ciência, Tecnologia e Inovação em Saúde.
} 
consenso social, enquanto Lula agregou temas relacionados aos movimentos sociais. Ao longo dos últimos governos, nota-se que:

As conferências tornaram-se um símbolo da democracia participativa no país em função da frequência que têm sido realizadas, do expressivo contingente de pessoas e movimentos sociais que têm envolvido e dos novos temas que têm introduzido no debate político. (PETINELLI, 2011, p. 229)

Outra observação tecida por Souza et al.. (2013) sobre as conferências nacionais é a de que, após a realização da $8^{a}$ Conferência Nacional de Saúde, elas teriam deixado um caráter especificamente técnico, tendo em vista que dentre os participantes a maior parte estava associada a profissionais que trabalhavam nas áreas foco da conferência, para agregar a participação de usuários (no caso, por exemplo, do SUS) e movimentos sociais. Conforme relato desses autores:

Realizada em 1986, em meio à redemocratização do país, a $8^{a}$ Conferência de Saúde é tida como importante marco para a história das conferências e para a ampliação da participação na gestão pública. Ela representou uma reconfiguração na postura do governo em relação ao uso das conferências, pois o caráter técnico-administrativo deu lugar a uma perspectiva mobilizatória-política. O debate técnico foi reposicionado quando a saúde passou a ser tratada enquanto direito do cidadão. A ampliação do envolvimento dos usuários dos serviços de saúde e o fortalecimento dos movimentos de profissionais da saúde tornaram as conferências espaços de disputa política. [...] lançou as bases para a democratização da saúde, tendo sido fundamental na articulação pelo Sistema Único de Saúde. Sua relevância extrapolou o setor, pois foi realizada em um contexto favorável e ganhou notoriedade pelo esforço de popularização do debate. Em contrate à participação restrita das primeiras conferências, essa contou com a participação de 4 mil delegados na etapa nacional. (SOUZA et al.., 2013, p.56)

A atual presidenta, Dilma Rousseff, deu continuidade a este olhar mostrado por Petinelli (2011) e presente no governo Lula: as conferências nacionais são adotadas nos governos do Partido dos Trabalhadores (PT) como uma política de governo. Por meio da institucionalização da PNPS, existe uma tentativa de transformá-las em uma política de estado, conforme é apresentado por Avritzer (2012, p. 8):

Assim, sob o ponto de vista do governo, a questão ressaltada é o aumento quantitativo das conferências nacionais mostrando que, de fato, existe hoje uma política participativa no nível federal de governo centrada nas conferências nacionais.

Outra evidência que observo como tentativa da institucionalização de uma política nacional de participação é a designação de setores do governo responsáveis 
por prover a participação e o diálogo entre sociedade civil e poder público. Especifica o marco legal:

\begin{abstract}
Art. 3o À Secretaria-Geral da Presidência da República compete assistir direta e imediatamente ao Presidente da República no desempenho de suas atribuições, especialmente:

I - no relacionamento e articulação com as entidades da sociedade civil e na criação e implementação de instrumentos de consulta e participação popular de interesse do Poder Executivo;

II - na elaboração da agenda futura do Presidente da República;

III - na preparação e formulação de subsídios para os pronunciamentos do Presidente da República;

IV - na promoção de análises de políticas públicas e temas de interesse do Presidente da República e na realização de estudos de natureza políticoinstitucional;

V - na formulação, supervisão, coordenação, integração e articulação de políticas públicas para a juventude e na articulação, promoção e execução de programas de cooperação com organismos nacionais e internacionais, públicos e privados, voltados à implementação de políticas de juventude. (BRASIL, Lei 10.683/2003, grifos meus).
\end{abstract}

Nesta formação ministerial que vigorou até outubro de 2015, havia dentro da estrutura da Secretaria-Geral da Presidência da República (SGPR), a Secretaria Nacional de Articulação Social, cuja responsabilidade era justamente articular as relações entre o governo e a sociedade civil, propor e apoiar novos instrumentos de participação social. A subsecretaria contava ainda com os departamentos de diálogos sociais, de participação social e o departamento de educação popular e mobilização cidadã.

Porém, com a reforma ministerial implementada a partir da Medida Provisória (MPV) n. ${ }^{\circ}$ 696/ 2015, a Secretaria-Geral da Presidência da República foi extinta, e com ela toda sua estrutura de subsecretarias e departamentos. Nesta reforma, a responsabilidade pelo diálogo com a sociedade civil, bem como a implementação de instrumentos de participação social foram realocados no Ministério de Direitos Humanos, Políticas para as Mulheres e Igualdade Racial.

A MPV n. ${ }^{\circ}$ 696/2015 não especificou a estrutura nominal das secretarias que compreendem o novo ministério. Desta forma, não é possível verificar se as subsecretarias e departamentos continuarão a existir.

O polêmico decreto presidencial n. ${ }^{\circ} 8243 / 2014$ que institui a PNPS e o SNPS evidencia a adoção da participação como uma política de governo, evocando a este a responsabilidade pela sua promoção enquanto direito instituído. Este decreto define as conferências como: 
Instância periódica de debate, de formulação e de avaliação sobre temas específicos e de interesse público, com a participação de representantes do governo e da sociedade civil, podendo contemplar etapas estaduais, distrital, municipais ou regionais, para propor diretrizes e ações acerca do tema tratado. (BRASIL, 2014)

Petinelli (2011, p. 231) definiu as conferências como "espaços públicos de participação e deliberação de diretrizes gerais de políticas públicas, organizadas tematicamente, que envolvem governo e sociedade civil". Próximo do pensado por ela, Souza et al.. (2013, p. 3) definem as conferências como:

Processos participativos de interlocução entre Estado e sociedade convocados pelo Poder Executivo, e desenvolvidos em etapas interconectadas a partir da escolha de representantes e da formulação de propostas para políticas públicas.

Ao problematizar as conferências da saúde, Guizard et al.. (2004, p.16) trazem possibilidades de perceber quais objetivos podem ser atribuídos às conferências na gestão das políticas públicas:

As conferências surgem como uma das arenas nas quais a participação social se antecipa à formulação de políticas, pois se volta para desenhar os princípios, diretrizes e pressupostos que devem orientar todo o processo de formulação de políticas de saúde no período seguinte.

Penso que tanto o descrito no decreto presidencial n. ${ }^{\circ} 8243 / 2014$, quanto 0 apresentado pelos referidos autores, evidenciam a divisão binária entre sociedade civil e governo - poder público -, segundo a qual a sociedade civil é quem fala e o poder público é quem ouve, para depois atender ao cliente ofertando serviços a serem consumidos (SOUZA, 2006). Por outro lado, ressalto como existente nas conferências o seu caráter propositivo, como um espaço - ou processos - de diálogo entre a sociedade civil e o governo.

Isto me faz pensar que entre o idealizado em 1941 por Gustavo Capanema, ao convocar a $1^{\text {a }}$ Conferência Nacional de Saúde, e o firmado no decreto presidencial, permanece a mesma narrativa sobre as conferências, que foi modificada ganhando exigências em sua estrutura organizativa e participativa ao longo das décadas.

No mesmo decreto são apresentadas as diretrizes mínimas das conferências nacionais:

Art. 12. As conferências nacionais devem observar, no mínimo, as seguintes diretrizes:

I - divulgação ampla e prévia do documento convocatório, especificando seus objetivos e etapas;

II - garantia da diversidade dos sujeitos participantes; 
III - estabelecimento de critérios e procedimentos para a designação dos delegados governamentais e para a escolha dos delegados da sociedade civil;

IV - integração entre etapas municipais, estaduais, regionais, distrital e nacional, quando houver;

$\mathrm{V}$ - disponibilização prévia dos documentos de referência e materiais a serem apreciados na etapa nacional;

VI - definição dos procedimentos metodológicos e pedagógicos a serem adotados nas diferentes etapas;

VII - publicidade de seus resultados;

VIII - determinação do modelo de acompanhamento de suas resoluções; e

IX - indicação da periodicidade de sua realização, considerando o calendário de outros processos conferenciais.

Parágrafo único. As conferências nacionais serão convocadas por ato normativo específico, ouvido o CGPS sobre a pertinência de sua realização. (BRASIL, 2014)

Sobre esta estrutura, chamada de desenho institucional, antes mesmo da edição do decreto, autores como Souza et al.. (2013), Petinelli (2011) e Romão (2014 classificam as conferências como típicas e atípicas:

- Típicas: apresentam características como a realização cíclica (muitas vezes definida em lei), organização por temas, caráter setorial, convocação por parte do Poder Executivo, a sociedade civil é integrada às comissões organizadoras, regimento interno, etapas interconectadas (municipal, regional, estadual ou distrital, nacional) e eleição de delegados para etapas subsequentes.

- Atípicas: são aquelas que não seguem o desenho institucional como mencionado acima.

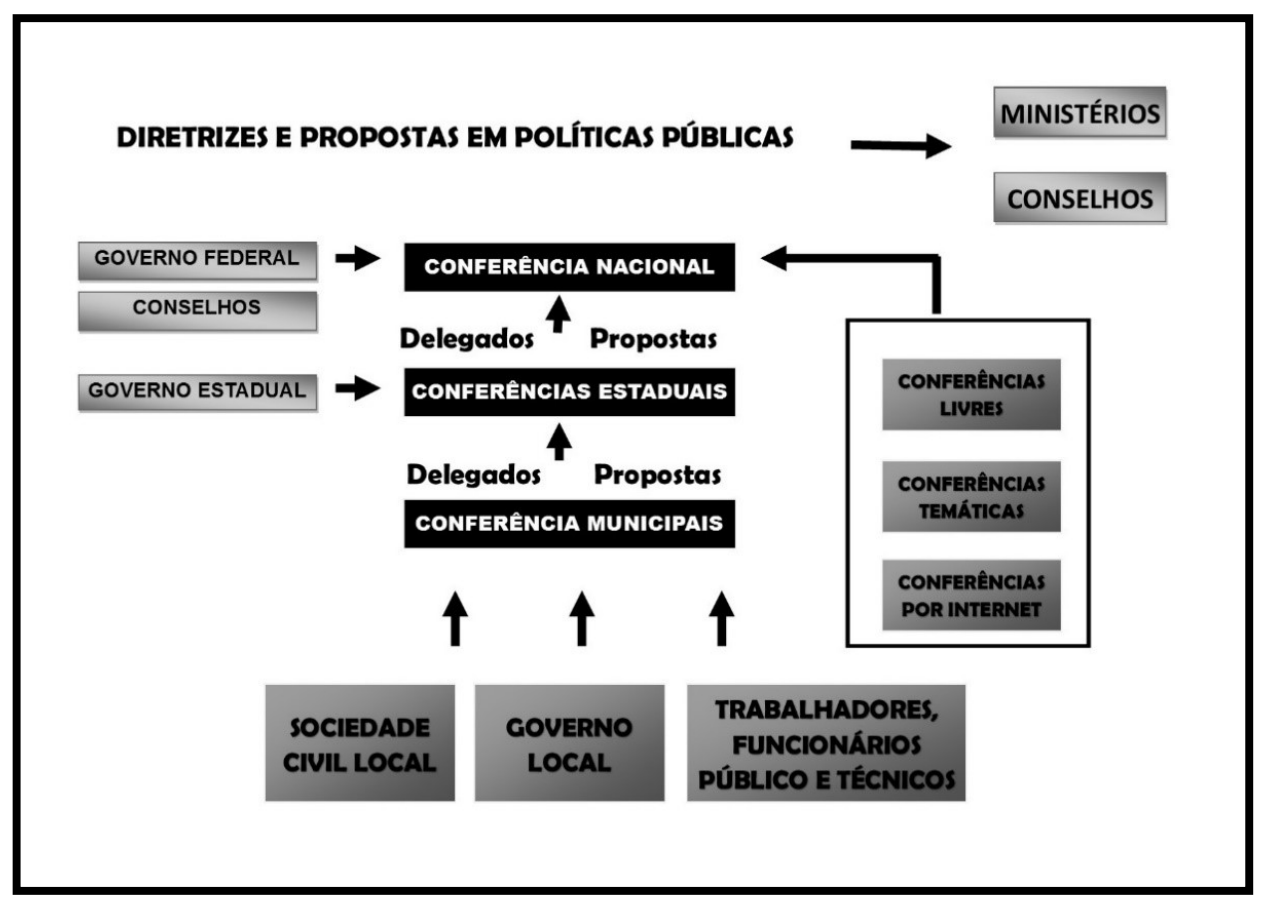

Figura 2 - Esquema das Conferências Típicas. 
Destaco, todavia, que, ao observar a estrutura das conferências realizadas ao longo dos governos Lula e Dilma, percebo que o desenho institucional de conferências típicas é seguido de forma quase integral. A estrutura das mesmas pode ser definida a partir da análise dos regimentos internos, ou através dos decretos presidenciais ou portarias ministeriais que convocam as conferências. Tais documentos são os responsáveis também por propor, ou não, etapas preparatórias (municipal, regional, estadual ou distrital).

Quanto ao perfil dos participantes, conforme Avritzer (2012, p.12-13), destaco que:

Por último, vale à pena salientar o perfil dos participantes nas conferências nacionais: a participante típica é uma mulher em $51,2 \%$ dos casos, com quatro anos de escolaridade $(26,9 \%)$ ou com ensino médio completo em $20,3 \%$ dos casos. A sua renda varia entre 1 e 4 salários mínimos (SM) em $52,2 \%$ dos casos. Assim, a primeira observação que gostaria de fazer em relação ao padrão de participação nas conferências nacionais é que ele é muito semelhante ao padrão de participação no nível local. Não são os mais pobres que participam, mas as pessoas na média de renda da população brasileira e, em geral, com escolaridade mais alta do que a média.

Penso que existe uma limitação ao definir o perfil dos participantes pela renda, uma vez que a média pode ser produzida por disparidades. Porém observo no apresentado por Avritzer (2012) a necessidade de produzir um perfil real sobre quem são os sujeitos participativos deste processo, talvez para confirmar o esperado por organismos internacionais, ou seja, a "participação dos setores populares no processo de decisão política em países em desenvolvimento e, particularmente, em países latino-americanos" (CORTES, 2002, p. 20).

Sobre a institucionalização de um modelo de conferências, Souza et al.. (2013) destacam que o envolvimento de outros entes federados no processo, a partir da realização de etapas municipais e estaduais ou distrital, não resulta na descentralização do processo, centralizado no governo federal e responsável pela convocação. Aos estados e municípios cabe a realização de suas etapas, seguindo o proposto pelos regimentos internos nacionais, e sua validação deve estar em conformidade com os mesmos. 


\title{
3.4- Reflexões sobre as conferências nacionais
}

Inicio estas reflexões a partir de uma percepção dos encontros a partir do governo Lula:

\begin{abstract}
A diferença no número e na proporção de encontros realizados no Governo Lula se deve ao fato de que este governo priorizou uma gestão democrática e participativa e, com tal objetivo, buscou construir um novo pacto com a sociedade civil por meio da criação e institucionalização de novos espaços participativos. (PETINELLI, 2011, p. 234)
\end{abstract}

O observado por Petinelli (2011) faz sentido, pois percebo tanto a maior quantidade de edições, quanto de temas tratando de reivindicação dos movimentos sociais, que tiveram papel importante na chegada de Lula e do PT ao poder.

Tais mudanças e a adesão a uma agenda governamental para participação devem-se também ao fato de pessoas ligadas aos movimentos sociais ascenderem a posições e cargos na gestão das políticas públicas. Neste sentido, são desencadeados esforços para estabelecer o diálogo entre o poder público e a sociedade civil:

As $\mathrm{IPs}^{42}$ são resultado da ação da sociedade civil brasileira durante o processo constituinte que resultou em um conjunto de artigos prevendo a participação social nas políticas públicas nas áreas da saúde, assistência social, criança e adolescente, políticas urbanas e meio ambiente. (AVRITZER, 2012, p. 10)

Considero que, para além do criar canais de diálogo, existe uma busca em facilitar caminhos para aprovação de pautas do governo, evocando sobre elas a voz e o clamor da sociedade civil.

Também, neste processo de implementação das conferências nacionais, como mecanismo para promover o direito à participação, além do reconhecimento legal de sua existência, foi-Ihes atribuída ainda uma formatação, um modelo a ser seguido para sua realização. As conferências passam a ser narradas na "condição de instância formal de exercício do princípio de participação da comunidade" (GUIZARDI et al.., 2004, p. 16). E neste ponto pode estar o paradoxo, e um caminho que buscarei evitar, o binarismo acerca da participação como liberdade e aprisionamento.

$42 \mathrm{O}$ autor refere-se a Instâncias Participativas (IP). 
Contudo, antes de produzir narrativas, ao serem institucionalizadas por dispositivos jurídicos, as conferências assumem o papel apresentado por Foucault (2015) ao falar da medicina, do casamento. As conferências passam a atuar como dispositivo na produção de discursos e narrativas acerca dos sentidos e significados, onde, como, quando e com quem participar.

As conferências também produzem discursos sobre o ser criança, adolescente, jovem, idoso. Sobre o que é saúde, homossexualidade, indígena, sobre o que é ser poder público, sociedade civil, e tantas outras populações que passam a ser territorializadas neste e em outros espaços participativos. Cada população passa a ser narrada a partir dos seus "fenômenos específicos e suas variáveis próprias" (FOUCAULT, 2015, p. 28).

A respeito das narrativas sobre a "população participante" das conferências, a sociedade civil, Guizardi et al.. (2004) apresentam os contornos discursivos a ela atribuídos:

Podemos observar que a participação da população é apresentada como
sendo mais ampla do que o controle, na medida em que envolve todo o
processo, a partir da formulação da intervenção no campo. Abrange, com
isso, desde seu interior à trajetória da política pública, revelando-se como
uma participação na constituição dessa política. Ou seja, com essa
concepção de participação, a população adquire condição de sujeito da
política de saúde, agente que a determina. (GUIZARDI et al.. 2004, p. 20)

Nestes dispositivos repletos de relações de poder, tensões e resistências existem também várias formas de governamentos que emanam não apenas do Estado, aqui concebido como poder público, mas também dentro dos próprios movimentos sociais, coletivos, ONGs, ou, melhor dizendo, dentro da própria sociedade civil.

Assim como afirma Foucault (2014, p.9), "em uma sociedade como a nossa, conhecemos, é certo, procedimentos de exclusão. O mais evidente, o mais familiar também, é a interdição". As interdições, nas conferências, aparecem nas disputas de poder, nas construções e nas defesas das narrativas que se colocam para ser prioritárias, ou para fazer parte dos documentos finais, nos acordos e nas negações de acordos políticos entre grupos e coletivos.

43 Guizardi et al.. (2004) fazem tais considerações a partir dos relatórios finais das Conferências Nacionais de Saúde, entre os quais o relatório da $8^{a}$ Conferência Nacional de Saúde, realizada em 1986. 
Nas conferências em que estive presente percebi este discurso autorizado, especialmente nos embates entre grupos governistas e oposicionistas no momento em que temas polêmicos como a descriminalização do aborto e das drogas e a redução da maioridade penal eram debatidos.

Neste contexto, a defesa de algumas posições gera tensão entre os grupos, em virtude de posicionamentos e discursos postos como verdade. Desta forma, estes espaços passam também a produzir discursos de verdades e formas de poder sobre a vida, que Foucault (2015) chamou de biopoder. Na participação, o biopoder passa a investir sobre os espaços e as condições de participação.

Porém, como salientado por Foucault, toda relação de poder e ação da biopolítica implicam também resistência. Sendo assim, como expõem Quintanilha e Dalberto (2014), os participantes criam possibilidades e se manifestam, mesmo quando não se sentem convidados. Acrescentaria a esse olhar que, mesmo quando são convidados, porém quando possuem seus discursos interditados, os representantes da sociedade civil não deixam de manifestar os seus desejos.

Neste espaço das conferências, ainda que algumas propostas estejam capturadas e a sua aceitação por parte dos participantes tenha teor de verdade, sempre haverá resistência em aceitar prontamente tais discursos capturados (CRIVELARO, 2013).

\begin{abstract}
Uma dimensão importante das conferências nacionais que é a percepção, por parte dos participantes, de um equilíbrio entre a participação do governo e da sociedade civil nas conferências nacionais. Sabemos que o governo sofreu importantes derrotas em algumas das suas propostas para políticas específicas, tal como foi o caso da resolução contra as Fundações Estatais na XII Conferência Nacional de Saúde. Assim, podemos afirmar que há também no campo da observação mais detalhada das conferências não apenas a evidência de um equilíbrio, mas frequentemente a constatação de que o governo nem sempre aprova as suas propostas durante as conferências nacionais. (AVRITZER, 2012, p.18-19)
\end{abstract}

Sobre isto, Pinto (2009) assinala que, mesmo sendo o Poder Público o disparador e o financiador das conferências, as relações de poder se dão de forma fluida, não estando concentrado em um único polo. Acrescento também que, nas conferências das quais participei, pude observar debates fervorosos, em que nem sempre as defesas feitas pelo poder público, ou por pessoas nomeadas como grandes lideranças de movimentos sociais, foram aceitas de forma pacífica, sem produzir tensões e conflitos. 
Outrora ${ }^{44}$ problematizei a importância das conferências a partir de Pogrebinschi et al. (2010) e Avritzer (2012), observando que as conferências "possuem um grande impacto nas políticas públicas, em especial para os grupos minoritários que ganham espaço para participar, opinar e debater as políticas públicas" (CRIVELARO, 2014, p.8). Hoje, acho importante destacar que tais minorias são colocadas neste território através de construções discursivas que se reverberam por meio da citacionalidade.

Ainda que as conferências sejam espaços de participação direta, ressalto que talvez o mais correto seja vê-las como um modelo de participação híbrida, considerando que, na etapa municipal, dependendo da sua forma de estruturação, a participação se consolida de forma direta. Porém, nas etapas subsequentes (regional, estadual e nacional), cabe aos participantes elegerem delegados, os quais novamente assumem o papel de representantes, passando neste momento ao caráter de participação representativa, considerando que o número de participantes, de tais etapas, passa a ser limitado (AVRITZER, 2012; CRIVELARO, 2013; CRIVELARO, 2014).

Sobre o alcance da população, Avritzer (2012) destaca que, embora apenas $6,5 \%$ da população assumam ter participado de uma conferência, o modelo é conhecido por $41,8 \%$ da população.

Ao relacionar as informações sobre o afunilamento do número de participantes promovido nas etapas finais das conferências e o conhecimento da população sobre o tema, acredito fazer sentido problematizar o verificado por Cortes (2002, p.25):

Embora a existência desses fóruns possa colaborar para a consolidação de formas mais democráticas de representação de interesses, eles têm seu funcionamento limitado e condicionado pela realidade concreta das instituições e da cultura política dos municípios brasileiros.

O narrado por Cortes apresenta a potência dos instrumentos e mecanismos de participação, ao considerá-los mais democráticos por envolver mais pessoas nos processos de formulação e decisão das políticas públicas, dentro do espaço participativo, quando comparados com a democracia representativa. Contudo, apresenta também limites relacionados ao desenho institucional, considerando que, nas conferências típicas, as primeiras etapas, justamente aquelas que envolvem maior número de participantes, ficam muitas vezes prejudicadas pela falta de

44 Trabalho apresentado no Seminário Internacional de Pesquisa em Políticas Públicas (2014). 
condições ou até mesmo de desejo dos municípios em realizar as conferências e possibilitar a participação direta da população.

Para analisar as reverberações produzidas pelas propostas aprovadas nas conferências, na tomada de decisão para implementação das políticas públicas, Petinelli (2011) cunhou um indicador nomeado de capacidade inclusiva das conferências. De forma simples, a capacidade inclusiva é delimitada a partir de análise dos relatórios das conferências e, a partir deles é feita pesquisa verificando o que foi incorporado à agenda pública, desde a criação de leis a implementação de políticas públicas.

A partir deste estudo tomando por base três conferências nacionais ${ }^{45}$, Petinelli (2011) constatou que as conferências com viés temático econômico possuem maior capacidade inclusiva, sendo três as variantes fundamentais deste indicador:

- maior capacidade inclusiva, quanto maior a importância dada pelo orçamento do ministério ou secretaria que realiza a conferência;

- maior capacidade inclusiva quando, entre os sujeitos envolvidos, estão os grupos empresariais; e,

- maior capacidade inclusiva quando o tema está relacionado à finalidade econômica.

Penso que, quando Petinelli afirma que as conferências que não estão diretamente associadas ao interesse econômico possuem menor capacidade inclusiva, é possível associar essa baixa inclusão ao incômodo que a potência produzida pelas propostas apresentadas pela população engendrada como minoria causa no status quo. Conforme problematizam Wendhausen e Cardoso (2007, p.581):

\begin{abstract}
Nem todos estes aspectos estão esclarecidos, mas já se sabe, por exemplo, que o aprendizado social e a doutrinação criam um clima de opinião que mantém muitos temas fora da agenda, especialmente aqueles que desafiam o status quo. Outra questão a ser abordada é que para que um assunto seja inserido na agenda é necessário que seja aceitável pelos especialistas, passar pelo critério do público e aí formar um consenso, que geralmente é obtido através de barganha.
\end{abstract}

No exposto por Wendausen e Cardoso, acredito que seja pertinente destacar dois pontos: primeiro, que não bastam todas as disputas para aprovação de determinadas propostas nas conferências, as barganhas continuam mesmo após a redação do relatório final, considerando as dificuldades que se encontram para

\footnotetext{
${ }^{45}$ Foram analisadas as Conferências Nacionais de Igualdade Racional, de Agricultura e Pesca e de
} Políticas para as Mulheres. 
transformar uma proposta em política pública; o segundo ponto é a eminente possibilidade de potência e resistência que são produzidas nestes espaços que servem para desestabilizar ainda que momentaneamente o status quo. Assim percebo que, embora o indicador proposto por Petinelli (2011) não capte tais elementos, talvez a verdadeira capacidade inclusiva das conferências esteja na possibilidade de produzir potência e resistência.

Dessa maneira, quero problematizar também que, apesar da possibilidade de verificar o quanto as vozes da sociedade civil são ouvidas e efetivadas no espaço das conferências pelo poder público, a capacidade inclusiva serve como indicador técnico, relacionado às capturas engendradas nos momentos de conferência. Porém, o indicador não consegue, e também não tem este objetivo, quantificar, ou talvez qualificar a vida enquanto potência "que funda e dispara singularidades", e tão pouco medir o agenciamento que "com essa força intensiva conduz à resistência à invenção" (Romagnoli et. al., 2009, p. 200).

Outros aspectos não indicados pela capacidade inclusiva, mas que estão presentes no espaço das conferências, e que também não estão capturados e traduzidos em números ou dados estatísticos, são o silenciamento e o distanciamento produzidos a partir da não vocalização dos desejos dos participantes, que muitas vezes são postos na marginalidade (QUINTANILHA; DALBERTO-ARAUJO, 2014).

Ao findar este capítulo com tais problematizações, não quero aqui discordar, ou reduzir as possibilidades da utilização do conceito de capacidade inclusiva, mas apenas problematizar que, apesar das capturas e tensões presentes nas relações de poder engendradas nas conferências, essa biopolítica também serve de potência, quando permite ao sujeito participante ser porta-voz de seus desejos ao estar neste espaço ou quando produz sensações e afetos nas tensões presentes nos momentos da conferência (QUINTANILHA; DALBERTO-ARAUJO, 2014).

Ainda que o espaço das conferências receba contornos de tecnologias que forjam “a construção de um homem 'organismo', 'indivíduo' e 'função', medido e julgado em sua adequação à norma, à normalidade instaurada" (GUIZARDI, 2014, p. 30) e esperada a partir da lógica do cidadão como sujeito de direito e protagonista, são nestas relações que "o poder se move somente na imanência de seu exercício, condição que o submete à liberdade, tornando a resistência e o escape imprescindíveis à sua dinâmica" (p. 32). 
Após apresentar possibilidades de problematizações a partir do tema participação, bem como capturas e possibilidade após instituição da política nacional de participação social, em especial no espaço das conferências, no Capítulo 5 retomarei estas problematizações a partir das Conferências Nacionais de Juventude realizadas de 2008 a 2015, buscando os sentidos e significados produzidos neste espaço a partir do município de Santa Bárbara d'Oeste. A seguir apresento os procedimentos metodológicos adotados na pesquisa. 


\section{4- PROCEDIMENTOS METODOLÓGICOS}

Nesta pesquisa me proponho a conhecer e problematizar, ainda que de forma provisória, os sentidos atribuídos ao ser jovem e à participação juvenil a partir do espaço das conferências municipais de juventude em Santa Bárbara d'Oeste.

Como método de pesquisa, optei por me aventurar na cartografia, a partir do desejo de me tornar um cartógrafo. Como se trata de meu primeiro contato com a cartografia enquanto método de pesquisa, talvez seja prudente me identificar como um aprendiz deste método pensado por Deleuze e Guattari (1995) e a mim apresentado por Passos e Barros (2015). Conforme assinalam estes últimos:

A Cartografia como método de pesquisa-intervenção pressupõe uma orientação do trabalho do pesquisador que não se faz de modo prescritivo, por regras já prontas nem com objetivos previamente estabelecidos. No entanto, não se trata de uma ação sem direção, já que a cartografia reverte o sentido tradicional de método sem abrir mão da orientação do percurso da pesquisa. (p.17)

E complementa Kastrup (2015, p. 32):

A cartografia é um método formulado por Giles Deleuze e Félix Guattari (1995) que visa acompanhar um processo, e não representar um objeto. Em linhas gerais, trata-se sempre de investigar um processo de produção.

Escolhi a cartografia devido às pistas do método sempre considerarem "os efeitos do processo do pesquisador sobre o objeto da pesquisa, o pesquisador e seus resultados", por considerar "a inseparabilidade entre conhecer e fazer, entre pesquisar e intervir: toda pesquisa é intervenção", e também pelo método cartográfico compreender o "saber-fazer, isto é, um saber que vem, que emerge do fazer. Tal primado da experiência direciona o trabalho da pesquisa do saber-fazer ao fazersaber, do saber na experiência à experiência do saber" (PASSOS; BARROS, 2015, p.17).

Para um pesquisador/militante imerso na história e produção das conferências de juventude em Santa Bárbara d'Oeste, seria muito difícil não considerar minha experiência e vivência neste processo. Até porque foram elas que me motivaram a estudar o tema.

Adotar a cartografia vem ao encontro de não considerar um caminho linear para atingir um fim, tão pouco isolar o objeto como proposto pela ciência moderna, mas sim 
descrever, discutir e, sobretudo, coletivizar a experiência do cartógrafo (BARROS; KASTRUP, 2015).

\begin{abstract}
A análise aqui se faz sem distanciamento, já que está mergulhada na experiência coletiva em que tudo e todos estão implicados. É essa constatação que força o institucionalismo a colocar em questão os ideais de objetividade, neutralidade, imparcialidade do conhecimento. Todo conhecimento se produz em um campo de implicações cruzadas, estando necessariamente determinado neste jogo de forças: valores, interesses, expectativas, compromissos, desejos, crenças etc. (p.20)
\end{abstract}

Diferente do apresentado pela ciência moderna, utilizar a cartografia para mim também é assumir que o fazer científico não se faz de forma neutra, tampouco descolado da realidade e da experiência, e também que toda pesquisa é intervenção. Portanto:

\begin{abstract}
Defender que toda pesquisa é intervenção exige do cartógrafo um mergulho no plano da experiência, lá onde conhecer e fazer se tornam inseparáveis, impedindo qualquer pretensão à neutralidade ou mesmo suposição de um sujeito e de um objeto cognoscentes prévios à relação que os liga. Lançados num plano implicacional, os termos da relação de produção de conhecimento, mais do que articulados, aí se constituem. Conhecer é, portanto, fazer, criar uma realidade de si e do mundo, o que tem consequências políticas. Quando já não nos contentamos com a mera representação do objeto, quando apostamos que todo conhecimento é uma transformação da realidade, o processo de pesquisar ganha uma complexidade que nos obriga a forçar os limites de nossos procedimentos metodológicos. (PASSOS; BARROS, 2015, p.30)
\end{abstract}

Desta forma, mergulhei nas conferências de juventude com a cartografia, confiando que "conhecer o caminho de constituição de dado objeto equivale a caminhar com esse objeto, constituir esse próprio caminho, constituir-se no caminho" (PASSOS; BARROS, p.31).

Adotando o pós-estruturalismo e as ideias de Foucault, assim como Kastrup (2015), defendo que o realizado não foi uma coleta de dados, mas sim uma produção discursiva sobre as conferências e o que é juventude, jovem e participação neste espaço, a partir das narrativas apresentadas pelos entrevistados e nos relatórios finais sobre conferências, bem como do meu fazer militante.

Saliento também, como afirma Fernandes (1992, p.16), que esta pesquisa repleta de inconclusões não tem por objetivo "atingir o limiar da representatividade", mas sim abrir novas possibilidades de estudo e pesquisa no tema.

Para isso, optei, na linha da cartografia, por chamar estas tentativas de voos e pousos por uma série de territórios. Nestes voos e pousos que ousei fazer durante 
esta pesquisa, penso que alguns territórios já eram conhecidos e foram revisitados. Porém, outros foram conhecidos e visitados pela primeira vez.

Utilizei os conceitos de pouso e território remetendo ao apresentado por Kastrup (2015, p. 34), que compara o "fluxo de pensamento ao voo de um pássaro que desenha o céu com seus movimentos contínuos, pousando de tempos em tempos em certo lugar. Voos e pousos diferem quanto à velocidade da mudança que trazem consigo".

Nestes voos feitos ao longo de quase três anos, resolvi pousar minha atenção nos seguintes territórios de observação: conferências de juventude, juventude e jovem e participação juvenil.

Tais territórios são observados a partir do prisma das quatro edições das conferências de juventude realizadas em Santa Bárbara d'Oeste. Trata-se das categorias de análise já apresentadas, ou ainda dos territórios por onde ousei pousar nesta pesquisa. Melhor dizendo, dos territórios por onde projetei a minha atenção. Segundo Kastrupp (2015):

\begin{abstract}
A atenção tateia, explora cuidadosamente o que the afeta sem produzir compreensão ou ação imediata. Tais explorações mobilizam a memória e a imaginação, o passado e o futuro numa mistura difícil de discernir. Todos esses aspectos caracterizam o funcionamento da atenção do cartógrafo durante a produção dos dados numa pesquisa de campo [...] Tomando como ponto de partida a ideia da concentração sem focalização, parece ser possível definir quatro variedades do funcionamento atencional que fazem parte do trabalho do cartógrafo. São eles o rastreio, o toque, o pouso e o reconhecimento atento. (p. 40)

O gesto de pouso indica que a percepção, seja ela visual, auditiva ou outra realiza uma parada e o campo se fecha, numa espécie de zoom. Um novo território se forma, o campo de observação se reconfigura. A atenção muda de escala. (p.43)
\end{abstract}

Ao pousar em cada território pude perceber, concordando com Veiga-Neto (1996, p.30), que "não há um porto seguro, onde possamos ancorar nossa perspectiva de análise, para, a partir dali, conhecer a realidade", e também que "em cada parada nós no máximo conseguimos nos amarrar às superfícies".

Como aprendiz de cartógrafo, cheio de incertezas, inseguranças e insights, voei e pousei nos territórios. Pude perceber que não são naturais, não estão dados, e tampouco possuem essência.

Busquei explorá-los "por olhares, escutas, pela sensibilidade aos odores, gostos e ritmos" (KASTRUP, p.61), resgatando inclusive minhas memórias de pesquisador militante presente nas conferências. 
Nesta minha aventura pela cartografia, ressalto que para os voos e pousos nos territórios contei com a minha experiência de pesquisador/militante acompanhado pelas perspectivas de jovens que participaram das quatro edições da conferência municipal de juventude em Santa Bárbara d'Oeste, e aceitaram retomar suas memórias e partilhar os sentidos e significados daquela vivência. Para isso, nesta pesquisa, utilizarei os seguintes procedimentos em minha cartografia:

1. Memórias, lembranças, sentidos de um militante, organizador e participante de todas as edições das conferências de juventude no município.

2. Leitura e revisitação dos relatórios finais das conferências de juventude.

3. Entrevistas com participantes e organizadores das quatro edições da Conferência Municipal de Juventude de Santa Bárbara d'Oeste - SP (2008, 2011, 2014, 2015).

Neste caminho metodológico para voar e pousar nos territórios desta investigação, organizei os resultados do caminho trilhado em dois capítulos.

No mesmo caminho metodológico, voei e pousei em muitos territórios e foi desafiadora a tarefa de organizar e sistematizar o material que produzi a partir das conferências, das memórias da minha trajetória e das entrevistas.

Diante do desafio, após muitas tessituras e mudanças, organizei o material em dois capítulos (5 e 6$)$.

\section{1- Voos e pousos sobre os relatórios das conferências e minhas memórias}

No Capítulo 5 apresento um relato das conferências, construído a partir das minhas memórias e do retorno aos relatórios das etapas municipais e estaduais das quatro conferências de juventude ${ }^{46}$. Esse capítulo se constitui num registro da história das conferências a partir da minha vivência. Ao mesmo tempo ele se configura como um elemento analítico a mais que me dá o panorama das conferências, territórios que

\footnotetext{
46 Optei por não sistematizar as etapas regionais e estaduais das conferências em decorrência do tempo disponível para a pesquisa, que não permitiu sistematizar o grande volume de material. Meu foco analítico são as conferências municipais, que avalio serem fortemente influenciadas pela conferência nacional, sendo por isso que optei por estas duas esferas.
} 
os jovens vivenciam ao produzir sentidos sobre a conferência, participação e juventude.

Para ter acesso aos relatórios finais produzidos nas conferências municipais de juventude, a pesquisa foi apresentada à equipe do Conselho Municipal de Juventude (CoMJuv) a fim de obter autorização ${ }^{47}$ para utilizar os relatórios finais produzidos nas edições das conferências de juventude.

A partir daí comecei meu primeiro voo buscando pousar sobre os territórios de minhas memórias que me permitiram tecer as primeiras linhas objetivando a sistematização delas nas quatro conferências municipais, das quais em três estive como organizador, e na última como participante. Em seguida, com os relatórios das conferências em mãos, comecei a costurar os retalhos representados pelas minhas memórias e pelo conteúdo presente nos relatórios finais, buscando dar forma à sistematização das quatro edições, que me permitiram, inclusive, refletir acerca do meu lugar enquanto organizador.

Pousando sobre os relatórios, busquei cartografar quais foram os temas utilizados em cada uma das edições, quantos foram os participantes, como a conferência foi avaliada pela Comissão Organizadora Municipal (COM) e quais as etapas em que o município de Santa Bárbara d'Oeste esteve representado.

Ao pousar sobre minhas memórias, pude cartografar sentidos, desejos, potências e capturas que não estão presentes nos relatórios finais, apresentando a forma como fui afetado, bem como produzi afeto nas/pelas conferências.

No caso das etapas nacionais, fiz o mesmo movimento partindo dos relatórios que foram divulgados a partir do site da Secretaria Nacional de Juventude (SNJ), porém agora atribuindo a eles as minhas percepções enquanto participante das etapas nacionais.

\section{2- Entrevistas}

As entrevistas foram utilizadas como ferramenta para captar as produções discursivas de organizadores e participantes da etapa municipal. A sistematização do material produzido é apresentada no Capítulo 6.

\footnotetext{
47 Vide Anexo F.
} 
Antes da realização deste procedimento, o projeto de pesquisa foi submetido à Plataforma Brasil ${ }^{48}$, e avaliado pelo Comitê de Ética em Pesquisa em Seres Humanos $(\mathrm{CEP})$ da Escola de Artes Ciências e Humanidades $(\mathrm{EACH})$ da Universidade de São Paulo.

Foi utilizada a entrevista semiestruturada que, conforme Alves e Silva (1992, p. 63) "pedem uma composição de roteiro com tópicos gerais selecionados e elaborados de tal forma a serem abordados com todos os entrevistados". Ainda, segundo as autoras:

\begin{abstract}
Esse formato pede também uma formulação flexível das questões, cuja sequência e minunciosidade ficarão por conta do discurso dos sujeitos e da dinâmica que flui naturalmente no momento em que entrevistador e entrevistado se defrontam e partilham uma conversa permeada de perguntas abertas, destinadas a "evocar ou suscitar" uma verbalização que expresse o modo de pensar ou de agir das pessoas face aos temas focalizados, surgindo então a oportunidade de investigar crenças, sentimentos, valores, razões e motivos que se fazem acompanhar de fatos e comportamentos, numa captação, na íntegra, da fala dos sujeitos. (p.64)
\end{abstract}

A utilização de entrevista com os participantes das conferências municipais de juventude realizada em Santa Bárbara d'Oeste tinha por objetivo conhecer e problematizar os sentidos atribuídos ao ser jovem e à participação juvenil a partir do espaço das conferências municipais de juventude. Para isso foi adotado o roteiro abaixo, com perguntas disparadoras do diálogo com os entrevistados.

1- De qual edição participou?

2- Como ficou sabendo das conferências?

3- Por que você foi participar da Conferência? Por que você acha que os jovens participam?

4- O que foi a conferência de juventude na sua opinião?

5- Que contribuições o espaço das conferências trouxe a você?

6- O que achou mais importante naquele momento?

7- Quais os empecilhos para a participação do jovem nestes espaços? O que poderia ser diferente?

8- Você conheceu os encaminhamentos/ resultados da conferência?

9- O que é participação juvenil para você?

10- O que é política pública para você?

11- O que é ser jovem para você?

12- O que é juventude para você?

13- Quais as maiores dificuldades de ser jovem na cidade de Santa Bárbara d'Oeste?

14- Como avalia a preocupação do poder público (executivo/legislativo) com o jovem barbarense?

15- Você gostaria de acrescentar alguma coisa?

Quadro 1 - Roteiro utilizado nas entrevistas

48 Vide Anexo G. 
Como dito anteriormente, por se tratar de entrevista semiestruturada, o roteiro acima é apenas provocador da entrevista. Por isto, durante as entrevistas, de acordo com o apresentado pelo entrevistado, sempre surgiam novas perguntas que possibilitavam melhor conhecer os sentidos e significados investigados na pesquisa.

O Termo de Consentimento Livre e Esclarecido (TLCE) $)^{49}$ era lido para cada entrevistado e solicitava-se sua assinatura. No caso dos menores de 18 anos, o mesmo era assinado pelos pais.

Em todos os passos da pesquisa busquei respeitar as diretrizes e normas regulamentadoras sobre pesquisa envolvendo seres humanos, conforme a Resolução n. ${ }^{\circ}$ 466/2012 do Conselho Nacional de Saúde. Em seguida, com os relatórios das conferências em mãos, comecei a entrar em contato com pessoas que figuravam no credenciamento das edições, apresentando a pesquisa e pedindo a contribuição através da entrevista.

Os possíveis entrevistados eram cartografados a partir da lista de credenciamento presente nos relatórios finais das etapas municipais. O contato se dava por telefone ou através de redes sociais como o facebook e o whatsapp, uitlizados apenas como ferramentas para convidar os participantes ou organizadores para a entrevista.

Foram entrevistados(as) 15 pessoas, 5 organizadores (1 mulher e 4 homens) e 10 participantes ( 5 mulheres e 5 homens). Considerei como organizadores as pessoas que tinham o nome publicado em decreto ou no relatório final das edições.

A cada entrevista, o sentimento de importância das conferências realizadas no município e a empolgação com o objeto de estudo cresciam. Ouvir os sentidos e significados apresentados pelos entrevistados dava a real dimensão do trabalho desenvolvido enquanto jovem e, até então, militante das políticas públicas de juventude.

Saliento que em virtude da primeira parte das entrevistas ter se realizado antes da $4^{a}$ Conferência Municipal de Juventude, em setembro de 2015, alguns envolvidos na organização ou como participante desta edição não narram as experiências, sentidos e significados da $4^{\mathrm{a}}$ Conferência.

49 Vide Apêndice A. 
Ao iniciar as entrevistas, solicitava aos meus interlocutores autorização para gravar o diálogo em arquivos de áudio. Finalizadas as entrevistas, estas foram transcritas, lidas e relidas várias vezes para construção dos mapas dialógicos.

\section{3 - Entrevistados: companheiros(as) de voos e pousos}

Considerei os entrevistados convidados para ajudar a compreender os sentidos de juventude, das conferências e de participação como pássaros que me ajudaram a voar como um bando em V, buscando com essa formação ajuda mútua durante os voos, aumentando a amplitude visual para observar os territórios.

A seguir, apresento os pássaros que me acompanharam neste voo produzindo e partilhando suas narrativas que me possibilitaram tecer os fios desta pesquisa. Visando preservar a identidade dos participantes, esclareço que os nomes utilizados não correspondem ao nome real dos entrevistados.

\begin{tabular}{|c|c|c|c|c|}
\hline $\begin{array}{c}\text { Nome } \\
\text { Fictício }\end{array}$ & $\begin{array}{c}\text { Participante/ } \\
\text { Organizador }\end{array}$ & $\begin{array}{c}\text { Edições de } \\
\text { participação }\end{array}$ & $\begin{array}{c}\text { Idade na época da } \\
\text { participação }\end{array}$ & $\begin{array}{c}\text { Idade durante } \\
\text { entrevista }\end{array}$ \\
\hline Dandara & Participante & $2008 / 2011$ & 13 anos/16 anos & 21 anos \\
\hline Thaís & Participante & 2011 & 15 anos & 19 anos \\
\hline Pedro & Organizador & $2008 / 2011$ & 41 anos/ 45 anos & 49 anos \\
\hline Caio & Organizador & $2014 / 2015^{*}$ & 26 anos & 27 anos \\
\hline Melissa & Participante & $2011 / 2014 / 2015^{50}$ & 30 anos/33 anos & 34 anos \\
\hline Hugo & Organizador & $2008 / 2015^{47}$ & 27 anos & 34 anos \\
\hline Davi & Organizador & $2008 / 2011 / 2014$ & 28 anos/31 anos & 35 anos \\
\hline Enzo & Participante & 2008 & 16 anos & 24 anos \\
\hline Lara & Participante & $2014 / 2015^{47}$ & 16 anos & 17 anos \\
\hline Félix & Participante & $2014 / 2015^{47}$ & 15 anos & 16 anos \\
\hline Amanda & Organizadora & 2011 & 27 anos & 31 anos \\
\hline Tom & Participante & 2008 & 24 anos & 31 anos \\
\hline Elis & Participante & 2015 & 19 anos & 19 anos \\
\hline Miguel & Organizador & 2015 & 21 anos & 22 anos \\
\hline Théo & Participante & 2015 & 16 anos & 17 anos \\
\hline
\end{tabular}

Quadro 2 - Apresentação dos participantes das entrevistas

\begin{tabular}{|c|c|c|c|c|c|}
\hline $\begin{array}{c}\text { Nome } \\
\text { Fictício }\end{array}$ & $\begin{array}{c}\text { Participou de } \\
\text { etapa } \\
\text { regional }\end{array}$ & $\begin{array}{c}\text { Participou de } \\
\text { etapa estadual }\end{array}$ & $\begin{array}{c}\text { Participou de } \\
\text { etapa } \\
\text { nacional }\end{array}$ & $\begin{array}{c}\text { Atuou no } \\
\text { poder } \\
\text { público }\end{array}$ & $\begin{array}{c}\text { Participou do } \\
\text { Conselho de } \\
\text { Juventude }\end{array}$ \\
\hline Dandara & Sim & Sim & Não & Não & Sim \\
\hline
\end{tabular}

50 Estas entrevistas ocorreram antes da realização da $4^{a}$ Conferência Municipal de Juventude. 
conclusão

\begin{tabular}{|l|c|c|c|c|c|}
\hline $\begin{array}{c}\text { Nome } \\
\text { Fictício }\end{array}$ & $\begin{array}{c}\text { Participou de } \\
\text { etapa } \\
\text { regional }\end{array}$ & $\begin{array}{c}\text { Participou de } \\
\text { etapa estadual }\end{array}$ & $\begin{array}{c}\text { Participou de } \\
\text { etapa } \\
\text { nacional }\end{array}$ & $\begin{array}{c}\text { Atuou no } \\
\text { poder } \\
\text { público }\end{array}$ & $\begin{array}{c}\text { Participou do } \\
\text { Conselho de } \\
\text { Juventude }\end{array}$ \\
\hline Thaís & Sim & Sim & Não & Não & Sim \\
\hline Pedro & Sim & Sim & Sim & Sim & Sim \\
\hline Caio & Não & Sim & Não & Não & Sim \\
\hline Melissa & Não & Não & Não & Não & Sim \\
\hline Hugo & Sim & Sim & Sim & Sim & Não \\
\hline Davi & Sim & Sim & Sim & Sim & Sim \\
\hline Lara & Sim & Não & Não & Não & Sim \\
\hline Enzo & Não & Não & Não & Não & Não \\
\hline Félix & Não & Não & Não & Não & Não \\
\hline Amanda & Não & Não & Não & Não & Não \\
\hline Tom & Não & Não & Não & Não & Não \\
\hline Elis & Sim & Não & Não & Não & Não \\
\hline Miguel & Sim & Sim & Sim & Não & Sim \\
\hline Théo & Sim & Sim & Não & Não & Não \\
\hline
\end{tabular}

Quadro 3 - Participação nas conferências e atuação

Os entrevistados foram escolhidos a partir de análise das fichas de credenciamento, constante nos relatórios finais das conferências municipais. Com os relatórios em mãos, procurei por pessoas que retratassem com maior abrangência a diversidade de grupos ou coletivos juvenis presentes ao longo das quatro edições. Com a realização das entrevistas, observei que o material de quinze entrevistas oferecia elementos suficientes para as problematizações que me propus realizar ao estabelecer os objetivos deste estudo.

Saliento que não foram entrevistados apenas jovens, se observada a classificação do Estatuto da Juventude (EJ). Entrevistei também pessoas envolvidas na organização e realização das conferências por desconfiar que as narrativas pudessem ser diversas, considerando também a experiência vivida na preparação do evento.

Depois de identificados possíveis entrevistados, o contato era feito por meio de telefone ou de redes sociais. Nesta tentativa de identificar companheiros nestes voos, ouvi 8 recusas. Quando os procurados aceitavam ao convite, as entrevistas eram agendadas em locais de escolha dos futuros entrevistados.

\section{4 - Análise das entrevistas - Mapas dialógicos}

Para analisar as entrevistas, optei pelo uso dos mapas dialógicos, por acreditar na possibilidade ofertada por esta ferramenta de sistematizar as entrevistas 
transcritas, identificando temas/territórios ${ }^{51}$ e subtemas de análise. Segundo Nascimento; Tavanti e Pereira (2014, p. 247), Mapa Dialógico pode ser assim definido:

Mapa dialógico [...] é um instrumento a ser usado na análise; constitui um dos passos iniciais da análise e pode auxiliar pesquisadores/as em uma aproximação com o material, na organização dos discursos e no "ferramental" que, no sentido dicionarizado, é um "[...] conjunto de meios pelos quais se pode realizar, perfazer ou alcançar algo; instrumento.

A relevância da utilização dos mapas dialógicos é apontada pelos autores já referidos:

\begin{abstract}
A proposta de fazer mapas dialógicos está diretamente atrelada ao referencial teórico-metodológico com que trabalhamos, a partir do qual consideramos relevante dar visibilidade ao processo de análise e ao contexto de coprodução das práticas discursivas. Quando estudamos as práticas discursivas, estamos interessados no modo como as pessoas falam, nos repertórios linguísticos usados ao descreverem o mundo em que vivem, assim como nas outras vozes presentificadas nessas falas, textos ou imagens... Um recurso que nos permite dar visibilidade aos passos dados na construção da pesquisa é a dialogia presente nos discursos analisados. (p.248, grifos dos autores)
\end{abstract}

As entrevistas realizadas foram gravadas e em seguida transcritas. Após várias leituras das transcrições, como já mencionado, construí um primeiro mapa dialógico que se configurava como uma grande construção discursiva envolvendo as perguntas, as respostas e os objetivos do estudo. Deste modo, o material produzido se originou do encontro entre entrevistador e entrevistados e sua análise engendra esta produção dialógica e toma em consideração os objetivos do estudo.

Em seguida, foram feitas novas leituras e releituras, o que me permitia revisitar as narrativas, em busca de cartografar possíveis sentidos.

A partir daí busquei fazer articulações entre os discursos produzidos, as pessoas que os produziram e o contexto da conferência, estabelecendo uma teia de relações entre as práticas discursivas que narravam as vivências e os sujeitos que estavam na conferência.

Depois de construídos e por facilitar melhor visualização das questões e destes temas/territórios, selecionei nas narrativas dos entrevistados quais elementos comporiam os territórios por onde voaria e pousaria na descrição da análise.

Como aprendiz de cartógrafo, ao elaborar o mapa dialógico não me restringi à lógica da resposta dada para cada pergunta, busquei aguçar minha percepção para a

51 A utilização dos termos "tema" e "subtema" tem como base o texto de Nascimento; Tavanti e Pereira (2014), já o conceito de território parte da ideia de territórios de observação apresentada por Kastrup (2015). 
ocorrência de sentidos que poderiam estar entrelaçados em toda a produção discursiva dos entrevistados.

Após idas e vindas, voos e pousos, os temas/territórios foram definidos a partir deste processo de várias decolagens e aterrissagens. No capítulo 6 são apresentados a partir da sistematização abaixo:

\begin{tabular}{|l|l|}
\hline TERRITÓRIOS/TEMAS & SUBTEMAS \\
\hline \multirow{2}{*}{ 1) Conferência } & 1A) Como ficou sabendo \\
\cline { 2 - 2 } & 1B) Sentidos atribuídos \\
\cline { 2 - 2 } & 1C) Dificuldades e desafios \\
\hline \multirow{2}{*}{ 2) Participação } & 2A) Sentidos \\
\hline & 2B) Motivação \\
\hline \multirow{2}{*}{ J) Juventude/Jovem } & $\begin{array}{l}\text { 3A) Sentidos do ser jovem e da } \\
\text { juventude }\end{array}$ \\
\hline & $\begin{array}{l}\text { 3B) Ser jovem em Santa Bárbara } \\
\text { d'Oeste e as relações com o poder } \\
\text { público }\end{array}$ \\
\hline
\end{tabular}

Quadro 4 - Temas/territórios e subtemas de análise

Como mencionado anteriormente, os capítulos 5 e 6 compreendem a análise desta pesquisa e serão apresentados a seguir atendendo ao proposto no início deste capítulo. 


\section{5- AS CONFERÊNCIAS NACIONAIS E MUNICIPAIS DE JUVENTUDE}

Neste capítulo apresentarei um panorama construído a partir das minhas memórias como participante desta história, organizador das etapas municipais e dos documentos das etapas nacionais.

Saliento, porém, que opto, como caminho metodológico, por sobrevoar os territórios das etapas nacionais e municipais. Desta forma, abordarei as conferências nacionais em virtude de serem as disparadoras de diretrizes e orientações para as demais etapas, dentre elas, as conferências municipais.

Já as etapas municipais de Santa Bárbara d'Oeste são foco e território fundamental de minha análise, pois foram importantes na minha trajetória e na história das políticas públicas de juventude do município.

Desta forma, o primeiro tópico a seguir será utilizado para descrever e mostrar um panorama deste voos e pousos pela conferência nacional. Utilizarei o segundo tópico para sobrevoar e cartografar os sentidos engendrados a partir da minha participação nas conferências municipais de juventude e da sua organização, nas quatro edições realizadas de 2008 a 2015.

\section{1- As Conferências Nacionais de Juventude}

A partir de 2007, a juventude torna-se temática das conferências nacionais, com a convocação da $1^{\text {a }}$ Conferência Nacional de Juventude, através de decreto de 5 de setembro de 2007 assinado pelo presidente Lula.

Tabela 3 - Balanço das Conferências Nacionais de Juventude

\begin{tabular}{|l|c|c|c|}
\hline \multicolumn{4}{|c|}{ continua } \\
\hline Informações & $1^{\text {a }}$ ConfJuv & $2^{\text {a }}$ ConfJuv & $3^{\text {a ConfJuv }}$ \\
\hline Ano de realização & 2008 & 2011 & 2015 \\
\hline Total de participantes na etapa nacional & 2100 & 3000 & 3133 \\
\hline Qtde. de Conferências municipais e territoriais & 841 & 1878 & $* 52$ \\
\hline Qtde. de Conferênciais estaduais/distrital & 27 & 27 & 27 \\
\hline Conferências livres & 689 & 122 & $* 53$
\end{tabular}


conclusão

\begin{tabular}{|l|c|c|c|}
\hline Informações & $1^{\text {a }}$ ConfJuv & $2^{\mathrm{a}}$ ConfJuv & $3^{\mathrm{a}}$ ConfJuv \\
\hline Conferências virtuais & 0 & 1 & $0^{54}$ \\
\hline Consulta aos povos tradicionais & 1 & 1 & 1 \\
\hline Total de participantes & 402.100 & 550.000 & 600.000 \\
\hline
\end{tabular}

Fonte: Adaptado de Crivelaro (2014, p.13-14) a partir de dados da SNJ

Após oito anos da inclusão da juventude neste mecanismo de participação, foram realizadas três edições, ocorridas em 2008, 2011 e 2015. Ao observar a Tabela 2, é possível verificar aumento do número de participantes e de conferências municipais e territoriais realizadas.

A partir de 2013, a Conferência Nacional de Juventude (ConfJuv) passou a ser prevista na lei n. ${ }^{0}$ 12.852/2013, denominada de Estatuto da Juventude (EJ). Este dispositivo jurídico, além de prever as conferências de juventude, também classifica como juventude a população compreendida entre 15 e 29 anos. De acordo com o Estatuto da Juventude, a ConfJuv deve ocorrer no intervalo máximo de $4 \operatorname{anos}^{55}$ e sua convocação é prerrogativa do governo federal, assim como cabem aos Estados, Distrito Federal e Municípios a convocação, respectivamente, das etapas estaduais, distrital e municipais.

No EJ, as ConfJuvs ganharam caráter de mecanismo do Sistema Nacional de Juventude (SINAJUVE), que visa criar uma rede envolvendo a União, Estados, Distrito Federal e Municípios na consecução das políticas públicas de juventude. Acredito ser importante dizer que o SINAJUVE foi uma das propostas apresentadas e aprovadas como prioritárias na $1^{\text {a }}$ ConfJuv. Porém, desde a promulgação do EJ, o SINAJUVE aguarda regulamentação por parte do governo federal.

Apesar disto, pesquisa realizada ${ }^{56}$ pela SNJ em 2013 constatou que $8 \mathrm{em}$ cada 10 entrevistados nunca ouviram falar das conferências de juventude, o que representa $81 \%$ dos entrevistados. A mesma pesquisa mostra que, como primeira menção, $15 \%$ dos jovens entrevistados acreditam que a atuação em conselhos, conferências, audiências públicas ou outros canais de participação pode contribuir para melhorar as coisas no Brasil, o que confere a esta menção o quinto lugar ${ }^{57}$, último entre as

\footnotetext{
${ }^{54} \mathrm{Na}^{\mathrm{a}}$ ConfJuv, não houve Conferência Virtual, porém foi disponibilizada plataforma digital, utilizada para apresentação de propostas e eleição de delegados.

55 Versam sobre a etapa nacional o inciso V, do Artigo 41. Etapas estaduais e distrital, inciso IV do art. 42. Etapas municipais, inciso IV do art. 43 - Lei 12.852 de 5 de agosto de 2013.

${ }^{56}$ Brasil. Secretaria Nacional de Juventude, 2014, p. 87 a 89.

${ }^{57} \mathrm{Em}$ primeiro lugar ficou " $A$ atuação em associações ou coletivos que se organizam por alguma causa" (26\%), seguido por "participação em mobilizações de rua e outras ações diretas" (20\%), seguida por
} 
possibilidades apresentadas no questionário fechado. Quando consideradas todas as menções, tais instrumentos participativos atingem 35\%, ficando este posicionamento em terceiro lugar ${ }^{58}$.

Estes números apontam que as conferências e os conselhos de juventude ainda são pouco conhecidos pela população que são seu alvo, e para quem foram criados. Outra questão que pode ser problematizada é que talvez os jovens não enxerguem nas conferências e nos conselhos espaço potencializador de mudanças.

Acredito ser importante, também, problematizar outras duas questões abordadas nesta pesquisa. Quando perguntados sobre as ações do governo para a juventude, $53 \%$ dos jovens responderam que os governos "conhecem as necessidades dos jovens, mas não fazem nada a respeito", $20 \%$ que "não sabem se os governos têm ou não ações para a juventude", 18\% que "apóiam e promovem programas e ações voltadas para a juventude" e $8 \%$ que "não conhecem nem se preocupam com as necessidades".

Quando perguntados sobre a existência de conselhos ou secretarias de juventude, em quase todas as esferas, o número de jovens que afirmou não saber se existem ou não tais estruturas aproxima-se de $3 / 4$ dos entrevistados ${ }^{59}$.

Isto significa que, embora tenham sido criadas para serem espaços de interlocução entre juventude e poder público, hoje estas estruturas, assim como as conferências, ainda atingem poucos jovens. Estes espaços normalmente são mais conhecidos por jovens militantes vinculados a grupos ou coletivos juvenis que atuam no segmento das políticas públicas de juventude. Ainda que, como afirma o relatório preliminar da pesquisa, "o desenvolvimento de estruturas específicas para políticas de juventude ainda é relativamente recente no país" (BRASIL, 2014, p.96), isto mostra a dificuldade encontrada por tais estruturas em atingir as juventudes que não estão inseridas em grupos e coletivos tradicionais de participação juvenil.

As Conferências Nacionais de Juventude, as SNJ, que, juntamente com o Conselho Nacional de Juventude (CONJUVE) e a Comissão Organizadora Nacional

\footnotetext{
"atuação pela internet, opinando sobre assuntos importantes ou cobrando os políticos e governantes" e "atuação em partidos políticos", ambas com 17\%.

58 "Participação em mobilizações de rua e outras ações diretas" (45\%), "A atuação em associações ou coletivos que se organizam por alguma causa" (44\%).

59 Estado: $72 \%$ não sabem se existem ou não, $23 \%$ alegam que existem e $4 \%$ que não existem; Municípios: $72 \%$ não sabem se existem ou não, $20 \%$ alegam que existem e $7 \%$ que não existem; Federal: $75 \%$ não sabem se existem ou não, $21 \%$ alegam que existem e $4 \%$ que não existem (Fonte Agenda Juventude Brasil, 2013, SNJ).
} 
(CON) são responsáveis pela organização e realização, definem as conferências como:

[...] Um amplo processo de debate e participação sobre o que a juventude quer para o Brasil. É um espaço para discutir, analisar, reivindicar e propor ações para os poderes públicos, mas também para pactuar instrumentos de monitoramento e ação entre as redes de organização com foco no controle social das políticas públicas de juventude. (BRASIL. SECRETARIA NACIONAL DE JUVENTUDE, 2015)

Neste sentido que lhe é atribuído, aparece, além da dimensão propositiva, o monitoramento e a avaliação das políticas de juventude, aqui nomeados também como controle social.

Após três edições das Conferências Nacionais de Juventude, penso que este espaço tem cumprido seu papel de discutir, analisar e servir como espaço de reivindicação e proposição ao poder público. Porém, no que tange ao monitoramento, denominado acima de controle social, este espaço tem apresentado dificuldades em cumprir este papel, servindo de exemplo o fato de estarmos na $3^{a}$ Conferência Nacional de Juventude sem ter clareza do funcionamento e da situação real em que se encontravam o Participatório e o Juventude Viva, programas governamentais implementados na gestão anterior da SNJ que sequer foram mencionados em espaços de debates ou em mesas de abertura por parte do CONJUVE e da SNJ. Este assunto foi ponto de crítica da Pastoral da Juventude, em carta divulgada após o findar da última edição.

A institucionalização das conferências de juventude como espaços públicos, onde os jovens possam ser protagonistas na elaboração de políticas públicas que os tenham como destinatários, surge de indicativo da UNESCO, conforme apresenta Souza (2006) e como aponta livro lançado pela própria UNESCO (2004) ao sugerir o que segue, conforme consta de sua publicação:

A fim de possibilitar mais diálogo, relação em redes e intercâmbio de
experiências, poderiam ser promovidas reuniões nacionais sobre juventudes
e políticas - uma vez por ano ou a cada dois anos, quando poderiam ser
trazidas a público as experiências realizadas nos espaços específicos de
atuação e simultaneamente poderiam ser discutidos temas do interesse
comum de todos os participantes. (UNESCO, 2004, p. 237)

Ainda que neste trecho não esteja especificada a palavra conferência, é possível relacionar o sentido e o objetivo da ferramenta proposta dentro do capítulo intitulado Algumas propostas específicas para a ação operacional, bem como o observado no excerto onde é proposto "realizar avaliações externas de processo 
sobre implementação e impacto dos programas constantes da Política Nacional de Juventude nos diversos níveis de governo" (UNESCO, p.237).

Penso que a conferência é o espaço de diálogo onde são discutidos temas de interesse juvenil, e deveria se constituir como um espaço no qual são avaliadas as políticas públicas em execução, bem como onde são apresentadas propostas que versam sobre as "vontades, desejos, percepções, críticas e propostas dos jovens" (UNESCO, p.237). Pode também ser pensado a partir da exposição apresentada por Leon, Dolejsiová e Falangola (2009,p.187), ao definirem as conferências de juventude:

São espaços de diálogo entre o poder público e a sociedade sobre os desafios do segmento juvenil e quais alternativas devem ser tomadas pelos governos para respondê-los. Elas são processos nos quais jovens e interessados na temática se reúnem para discutir a situação das pessoas que compõem esta faixa etária e apontar quais são as prioridades de ações e programas a serem desenvolvidos pelo poder público. Esse debate inclui também a avaliação sobre políticas públicas em curso.

Buscando destacar suas percepções sobre este espaço, Almeida (2009) tece os significados delas para o universo juvenil:

A princípio, a ideia das conferências convida cada grupo juvenil a sair do seu
habitat. Cada grupo, por mais diferente que seja, deve dialogar com outro
grupo sobre os mais variados temas da condição juvenil contemporânea.
Assim, é comum observar, nas conferências, jovens homossexuais
discutindo com jovens de inserções religiosas sobre o uso ou não de
preservativos, bem como, jovens do PT disputando com jovens do PSDB
determinadas propostas. O que se pretende aqui é chamar a atenção para a
riqueza do exercício democrático que se ensaia nestas conferências. Não se
quer, com isso, afirmar que a conferência elimina as diferenças e que todos
saem do evento de mãos dadas como bons amigos. Muito pelo contrário. O
diferente e o conflito estão presentes a todo momento e são parte integrante
da construção coletiva. A difícil tarefa da tolerância é exercitada a todo
instante, pois os conflitos vêm à tona em cada oficina, palestra ou discussão.
Aliás, foi extremamente conflituoso o encerramento da citada conferência
nacional ${ }^{60}$. (ALMEIDA, 2009, p. 36 )

O referido autor destaca as potencialidades apresentadas por este espaço à juventude, tanto na possibilidade de respeito e convivência entre diferentes, bem como nas tensões existentes ao longo do processo, que, assim como ele, observei ao participar das três edições das referidas conferências. As tensões, conflitos e estranhamentos são frutos neste processo divergente e de disputa de poder, visando aprovar, ou não, as propostas que comporão o documento final em uma conferência.

Sobre as disputas de poder decorrente dos processos de participação social, saliento como Souza (2011, p.167) que:

60 O autor faz referência a conferência realizada em 2004, pela Câmara dos Deputados. 
É necessário reconhecer também que a ideia de participação social enquanto processo compartilhado de poder e de deliberação e influência está em disputa dentro do governo e também entre aqueles e aquelas que constituem hoje a sociedade civil.

Este pensamento reforça o entendimento de que os pontos de poder não são fixos, bem como a existência de pontos de resistência dentro das relações sociais, o que difere do apresentado no documento base da $3^{\text {a }}$ Conferência Nacional conforme nele consta:

Desde a $1^{\text {a }}$ Conferência, em 2008, e em seguida a $2^{\mathrm{a}}$, em 2011, a SNJ vem
adotando um modelo de gestão participativa, de permanente interlocução
com o CONJUVE, com os conselhos estaduais e municipais, bem como
coletivos e movimentos existentes no país, universidades e organismos
governamentais. O objetivo é compartilhar o poder e a corresponsabilidade
entre o Estado e a sociedade civil na elaboração de políticas públicas de
juventude. (BRASIL, 2015, p.5)

A conferência neste trecho é citada como um espaço onde o governo, que detém o poder, opta por compartilhá-lo com a sociedade civil. Nesta narrativa o Governo compartilha o poder que possui. Não é um poder que está circulando entre diferentes segmentos, é um poder que o Estado detém e generosamente compartilha. Quando adotamos a perspectiva foucaultiana de poder, este apontamento é passível de questionamento, tanto pelo fato de que o poder dos jovens não provém somente do poder que o Estado Ihes outorga, como também porque esta perspectiva coloca os jovens no lugar de tutelados (aqueles que têm que receber o poder que o Estado Ihes dá)

Sobre o conteúdo das propostas, Almeida (2009, p.36) observa as tensões e as relações de poder entre os diferentes paradigmas que tensionam as conferências, quando expõe que "participam vários atores juvenis, pautados por velhos ou novos paradigmas políticos", sendo o resultado imprescindível.

A seguir, tecerei narrativas sobre cada uma das 3 edições das Conferências Nacionais de Juventude. 


\subsection{1 - $\quad \underline{1^{\text {a }} \text { Conferência Nacional de Juventude }}$}

Realizada de 27 a 30 abril de 2008, com o lema "Levante a sua bandeira", no Parque das Cidades, em Brasília, a $1^{\text {a }}$ Conferência Nacional ${ }^{61}$ reuniu 2 mil e 100 pessoas, mobilizando 402 mil e 100 pessoas ao longo das etapas municipais, regionais, estaduais e distrital, consulta às comunidades tradicionais, livres ${ }^{62}$ e na etapa nacional, realizadas de setembro de 2007 a abril de 2008. Penso que o tema proposto para esta conferência é um convite da SNJ e do CONJUVE aos jovens, para a militância em torno das políticas públicas. O tema e a própria constituição da identidade visual do evento apontam para um chamado aos jovens para ocupar os espaços de participação e dizer quais são suas bandeiras enquanto jovens. O levante sua bandeira na verdade representa um "apresente", ou diga "qual sua proposta para a juventude". Trata-se de um convite para os jovens assumirem o seu papel enquanto protagonistas, afinal, sob esta ótica, só quem é protagonista ocupa papel de destaque e consegue tomar a palavra, ocupando lugar no palco das conferências.

$\mathrm{Na}$ etapa nacional, os participantes estiveram divididos em 21 eixos que tinham a responsabilidade de analisar todas as propostas apresentadas ao longo das etapas preparatórias, inclusive reescrevendo-as e, em seguida, escolhendo três prioridades que iriam para votação entre os delegados presentes, a fim de eleger as 22 prioritárias. Além dos GTs (grupos de trabalho), a etapa contou com leque variado de atividades disponibilizadas aos participantes de forma paralela aos grupos de trabalho.

Ao chegar à conferência, nem sempre os GTs dos quais queríamos participar possuíam vagas, desta forma éramos orientados a nos inscrever em outros. Porém os participantes sempre encontravam uma forma de participar do grupo desejado.

Alguns GTs, como Educação Básica, apresentaram grandes tensões, para além do esperado, como a escolha das propostas que seriam apresentadas para votação. Visando aprovar, entre as proposições do GT, a expansão dos Centros Integrados de Educação Pública (CIEPs), jovens vinculados à Juventude Socialista (JS), ligada ao Partido Democrático Trabalhista, ocuparam em massa este GT, o que

61 Conforme já apresentado em Crivelaro (2013; 2014), a Conferência promovida pela Câmara dos Deputados em 2006, devido ao seu formato, foi contabilizada como seminário e não é vista como uma conferência.

62 As etapas livres são conferências consideradas não eletivas, tendo finalidade apenas de levantar propostas que, depois de enviadas à Comissão Organizadora Nacional (CON), são validadas, entrando suas propostas no documento base que será discutido na etapa nacional. Elas não precisam seguir delimitações territoriais, podem ser abertas, ou realizadas no interior de grupos e coletivos. 
gerou muito tumulto durante a votação que só foi concluída após a conferência dos crachás para certificar que os presentes de fato pertenciam àquele GT.

\begin{tabular}{|c|c|}
\hline Edição & $1^{\text {a }}$ Conferência Nacional de Juventude (2008) \\
\hline Tema & 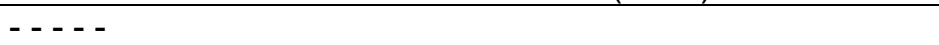 \\
\hline Lema & Levante sua bandeira \\
\hline Temas gerais (eixos) & $\begin{array}{l}\text { I - Juventude: Democracia, Participação e Desenvolvimento } \\
\text { Nacional; } \\
\text { II - Parâmetros e diretrizes da Política Nacional de } \\
\text { Juventude; } \\
\text { III - Desafios e Prioridades para as Políticas Públicas de } \\
\text { Juventude. }\end{array}$ \\
\hline $\begin{array}{l}\text { Temas para os grupos de } \\
\text { trabalho (GTs) }\end{array}$ & $\begin{array}{l}\text { 1- Jovens negros e negras; } \\
\text { 2- Educação básica - elevação da escolaridade; } \\
\text { 3- Ensino Superior; } \\
\text { 4- Trabalho; } \\
\text { 5- Cultura; } \\
\text { 6- Política e participação; } \\
\text { 7- Fortalecimento institucional da política de juventude; } \\
\text { 8- Meio ambiente; } \\
\text { 9- Juventude do campo; } \\
\text { 10- Esporte; } \\
\text { 11- Jovens mulheres; } \\
\text { 12- Segurança; } \\
\text { 13- Povos e comunidades tradicionais; } \\
\text { 14- Cidadania GLBT; } \\
\text { 15- Jovens com deficiência; } \\
\text { 16- Família; } \\
\text { 17- Drogas; } \\
\text { 18- Sexualidade e saúde; } \\
\text { 19- Tempo livre e lazer; } \\
\text { 20 -Comunicação e inclusão digital; } \\
\text { 21 - Cidades. }\end{array}$ \\
\hline
\end{tabular}

Quadro 5 - Temário e eixos da $1^{\text {a }}$ Conferência Nacional de Juventude ${ }^{63}$

Nos espaços que rodeavam este momento e as plenárias, eram constantes as reuniões entre coletivos e grupos juvenis para avaliar a participação e definir quais as propostas seriam defendidas tanto nos GTs, quanto nos momentos de votação.

Para a votação das propostas escolhidas nos GTs, os delegados receberam etiquetas em diferentes cores, visando à escolha das 17 propostas que automaticamente já estariam entre as prioridades. As demais propostas, em uma espécie de repescagem realizada na plenária final, foram novamente votadas em plenária final a fim de eleger inicialmente 4 prioritárias que mais tarde, por decisão da plenária, transformaram-se em 5 propostas.

A $1^{\text {a }}$ Conferência Nacional de Juventude definiu 70 resoluções finais, destacando entre elas 22 como prioritárias ${ }^{64}$.

${ }^{63}$ Adaptado de Crivelaro, 2013.

${ }^{64}$ Para conhecer as resoluções aprovadas na $1^{\text {a }}$ Conferência Nacional de Juventude vide Anexo 9. 
Como membros da Pastoral da Juventude, durante a votação nós éramos fortemente assediados para votar em determinadas propostas. Em alguns momentos, fomos procurados pelo movimento feminista para votar favoravelmente à proposta de legalização e descriminalização do aborto. Porém, dentro da PJ fomos orientados a ter cuidado, ao votar nas propostas, em especial se estivéssemos com camisetas da pastoral. Isto se dava devido ao posicionamento da Igreja em relação ao tema.

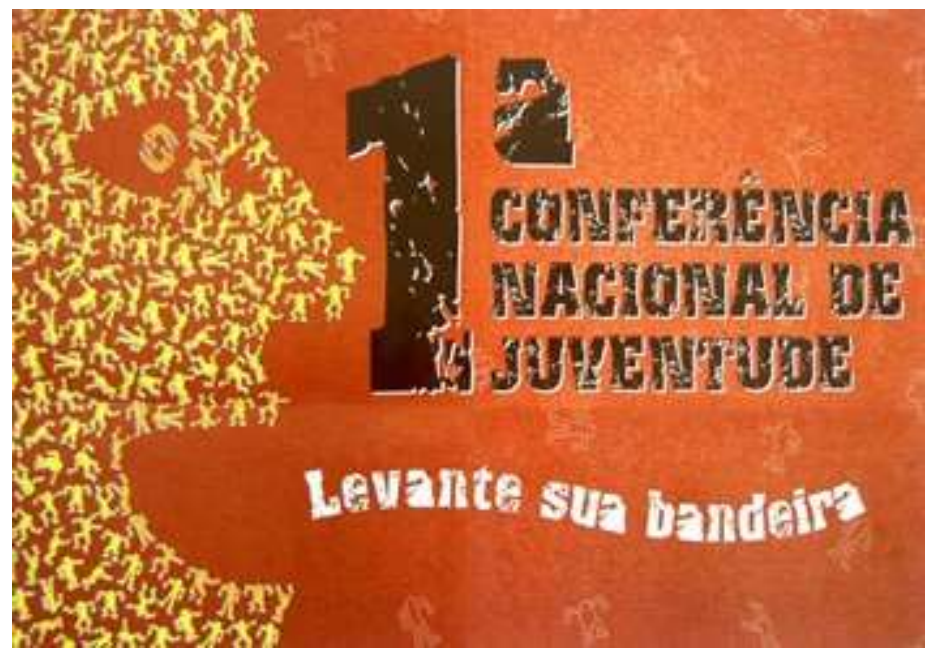

Figura 3 - Identidade visual da $1^{\text {a }}$ Conferência Nacional de Juventude Fonte: Anchietanum, 2007.

Conforme o já mencionado por Almeida (2009), também observei a diversidade no que tange aos grupos e coletivos juvenis presentes ao longo do processo, dentre os quais destaco jovens ligados a partidos políticos, comunidades tradicionais, movimento negro, movimentos religiosos, movimento LGBT, movimento estudantil, movimento feminista entre outros movimentos sociais e representantes de governos municipais, estaduais e da própria união.

Embora o respeito à diversidade fosse a tônica da conferência, as tensões e as disputas de poder existiam relacionadas à aprovação das propostas, pois nem sempre havia consenso entre as diferentes forças políticas no que tange às bandeiras que deveriam ser escolhidas como prioritárias.

Outro ponto sobre a diversidade de grupo que me recordo foi a situação provocada por um grupo de aproximadamente 6 integrantes do Partido da Social Democracia Brasileira (PSDB) que tentou adentrar no espaço da plenária carregando uma bandeira do partido, entoando palavras de ordem contra o governo Lula. A ação 
do grupo foi interrompida por militantes pró-governo Lula que retiraram a bandeira das mãos dos tucanos, encerrando a manifestação.

Entre os aspectos que vejo como destaque nesta conferência está a possibilidade da realização de etapas livres, sendo este ponto também destacado por Almeida (2012, p. 38-9), bem como no relatório final desta edição:

\begin{abstract}
Estas etapas possibilitaram a mobilização de públicos que possivelmente não se engajariam em uma conferência de formato padrão. Ademais, formularam propostas que foram encaminhadas às comissões organizadoras para sistematização e inclusão nos textos das etapas posteriores.
\end{abstract}

Ainda sobre a realização das Conferências Livres, consta no Caderno de Resoluções da $1^{\text {a }}$. Conferência Nacional da Juventude (s.d., p.7):

As Conferências Livres incentivaram que os interessados preparassem os eventos a partir de seus próprios conceitos. Assim, houve liberdade para organizar essa participação de maneira mais produtiva, permitindo a experimentação e a criação de novas metodologias. Com isso, conseguimos valorizar as experiências dos participantes e reconhecer que as redes são uma importante energia para mobilização social

Outro aspecto que merece destaque é que muitas propostas apresentadas como prioritárias pela juventude possuem abrangência que reverbera para além da população de 15 a 29 anos. Algumas propostas no GT de Trabalho são vistas em outros documentos apresentados pela Central Única dos Trabalhadores (CUT). Outras ainda são muitas vezes vistas como mobilizadoras de temas proibidos, já que no seio da sociedade tais temas são interditos, como mudanças de legislação que envolvem o aborto, por exemplo. Sobre isto o relatório final refere que:

Mas a juventude não pensou só nas suas reivindicações específicas. Os jovens debateram e afirmaram opiniões sobre vários temas polêmicos na agenda pública. Dentre eles, vale destacar a questão da legalização do aborto, que aparece entre as propostas mais recorrentes no tema Sexualidade e Saúde. No tema Segurança, os jovens se posicionaram contra a redução da maioridade penal e apresentaram propostas ligadas aos direitos humanos e à polícia comunitária. (BRASIL, 2008, p.9)

No Anexo $\mathrm{H}$ apresento as propostas eleitas como prioritárias.

Para mim esta conferência foi um momento de novidade, de festividade e ao mesmo tempo de aprendizagem. Primeiro porque nunca havia viajado de avião, e esta primeira viagem foi possível pela participação na Conferência, sem ônus financeiro. Segundo, porque não havia participado de um espaço com tal dimensão e proposta. Foi meu primeiro contato efetivo no debate das políticas públicas nacionais em um espaço instituído, e lá pude desfrutar da companhia de outras pessoas com objetivos 
próximos aos meus. Muitas amizades construídas naquela oportunidade, ainda que prejudicadas pela distância, continuam presentes através das redes sociais, inclusive contribuindo com conselhos e incentivos neste momento de dissertação.

\subsection{2 - $\quad \underline{2^{\mathrm{a}} \text { Conferência Nacional de Juventude }}$}

Com o tema "Juventude, desenvolvimento e efetivação de direitos" e o lema "Conquistar direitos, desenvolver o Brasil", de 9 a 12 de dezembro de 2011 foi realizada no Parque das Cidades, em Brasília-DF, a $2^{a}$ Conferência Nacional que objetivava a construção do Plano Nacional de Juventude para o período de 20122015.

O tema e o lema propostos são um mote de continuidade aos de 2008 . Em tese, as bandeiras já haviam sido levantadas. Neste segundo momento é preciso efetivá-las através da consolidação jurídica dos marcos legais, em referência especial a Projeto de Emenda à Constituição (PEC) da Juventude e ao EJ que não tinham sido aprovados. O lema com viés desenvolvimentista, do meu ponto de vista, dentro do proposto pelos organismos internacionais, buscava reforçar a ideia de que só seria possível desenvolver o país através da participação juvenil, assegurando a esta categoria social o status de cidadão, que seria adquirido, supostamente, a partir do seu reconhecimento enquanto categoria na constituição federal. A partir daí haveria previsão de direitos para os integrantes deste grupo que seriam então reconhecidos como cidadãos e sujeitos de direitos. O tema remete ao problematizado anteriormente, do jovem construído discursivamente como o ator social estratégico responsável pelo desenvolvimento do país.

As imagens presentes no cartaz de divulgação são fotografias feitas durante a $1^{\text {a }}$ Conferência em 2008 e buscam remeter a uma diversidade do ser jovem. 


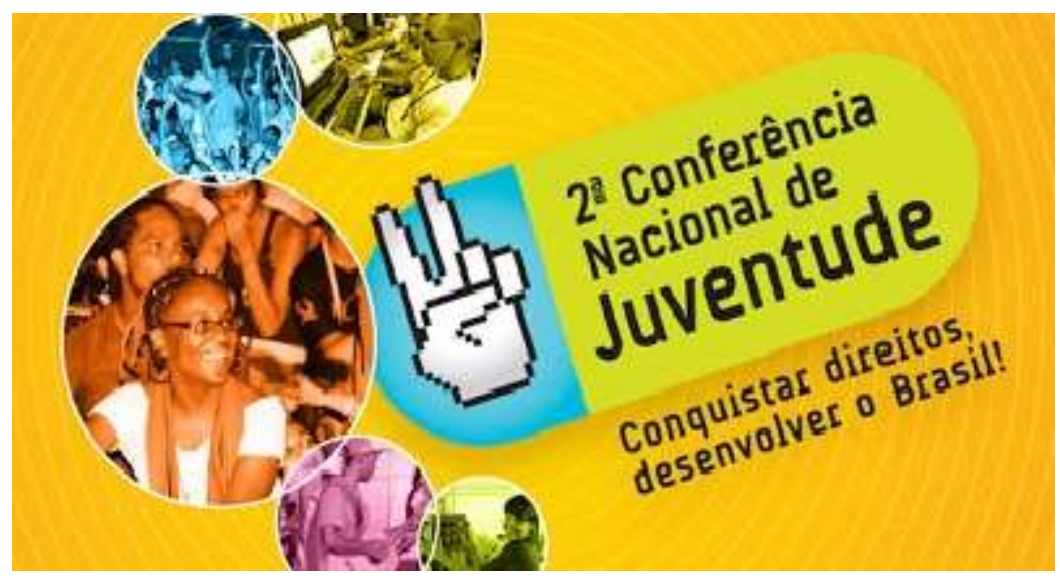

Figura 4 - Identidade visual da $2^{\text {a }}$ Conferência Nacional de Juventude

De modo diferente do que aconteceu na $1^{\text {a }}$ Conferência, esta edição contou com um texto base, que era na verdade uma minuta do Plano Nacional de Juventude (2012-2015), cabendo aos delegados apresentarem emendas supressivas, aditivas ou substitutivas ao texto. Porém, em especial nas etapas municipais, os jovens encontraram muita dificuldade, e por vezes recusavam-se a debater nos GTs a partir da metodologia estipulada, o que demandou muita criatividade das equipes de sistematização que precisavam enviar relatórios, obedecendo ao estipulado no regimento nacional, ou seja, valeriam apenas emendas ao texto base e não "bandeiras levantadas", como na edição nacional.

Ao chegar à etapa nacional, diante das dificuldades apresentadas pela metodologia, a Comissão Organizadora Nacional (CON) resolveu dividir as proposições em dois documentos, contemplando a possibilidade de seguir com a metodologia proposta, mas também permitindo que as "bandeiras"65 prioritárias fossem escolhidas. De modo geral, os textos finais e a metodologia estavam estruturados nesta edição como descrevo em trabalho apresentado em 2014:

Na etapa nacional, onde participaram aproximadamente 3 mil pessoas, os
delegados foram divididos em grupos pelas temáticas inclusas nos eixos,
onde deveriam destacar três propostas prioritárias e aprovar ou não as
emendas ao texto base. Em um segundo momento, os grupos eram
reagrupados por eixos temáticos, devendo entre as propostas aprovadas em
todos os grupos que compunham o eixo, destacar uma proposta por tema e
mais uma que seria escolhida na plenária do eixo. A plenária final discutiria e
aprovaria as propostas aprovadas nas plenárias de eixo. Ao término, a
segunda edição, além dos textos da moção aprovada, contou com três
documentos: o documento intitulado "Para desenvolver o Brasil"66, que
continha propostas nos diversos eixos, que eram pontos convergentes que
foram apontados nas etapas preliminares; o segundo "Propostas finais

65 Considero como bandeiras as propostas que eram formuladas a partir da criatividade dos participantes, sem um texto base, com propostas pré-definidas.

66 Vide Anexo I. 
aprovadas", que continha o resultado das proposições aprovadas nos grupos de trabalho e também ratificadas na plenária final em um total de 26 propostas aprovadas $^{67}$ e o "Documento Base", texto com as emendas aprovadas para compor o Plano Nacional de Juventude (2012-2015). (CRIVELARO, 2014, p.14)

Já as temáticas estavam estruturadas em cinco eixos que serviram de base para o EJ, conforme disposto no Quadro 6:

\begin{tabular}{|c|c|}
\hline Edição & 2 $^{a}$ Conferência Nacional de Juventude (2011) \\
\hline Tema & Juventude, Desenvolvimento e Efetivação de Direitos \\
\hline Lema & Conquistar Direitos Desenvolver o Brasil \\
\hline Temas gerais(eixos) & $\begin{array}{l}\text { I- Juventude: Democracia, Participação e Desenvolvimento } \\
\text { Nacional; } \\
\text { II - Plano Nacional de Juventude: prioridades 2011-2015; } \\
\text { III - Articulação e integração das políticas públicas de juventude. }\end{array}$ \\
\hline $\begin{array}{l}\text { Temas para os } \\
\text { grupos de trabalho }\end{array}$ & $\begin{array}{l}\text { Eixo 1- Direito ao desenvolvimento integral } \\
\text { 1- Educação - Ensino fundamental e ensino médio } \\
\text { 2- Educação - Ensino Superior } \\
\text { 3- Educação - Ensino Técnico e Profissionalizante } \\
\text { 4- Trabalho decente } \\
\text { 5- Cultura } \\
\text { 6- Comunicação } \\
\text { Eixo 2- Direito ao território } \\
\text { 7- Cidade } \\
\text { 8- Campo } \\
\text { 9- Transporte público } \\
\text { 10- Meio ambiente } \\
\text { 11- Comunidades e povos tradicionais } \\
\text { Eixo 3- Direito à experimentação e qualidade de vida } \\
\text { 12- Saúde } \\
\text { 13- Esporte e lazer } \\
\text { 14- Tempo livre } \\
\text { Eixo } 4 \text { - Direito à diversidade e à vida segura } \\
\text { 15- Direitos humanos } \\
\text { 16- Segurança } \\
\text { 17- Questões étnico-raciais } \\
\text { 18- Questões LGBT } \\
\text { 19- Gênero } \\
\text { Eixo } 5 \text { - Direito à participação e ao fortalecimento Institucional } \\
\text { 20- Participação } \\
\text { 21- Fortalecimento Institucional }\end{array}$ \\
\hline
\end{tabular}

$\mathrm{Na} 2^{\mathrm{a}}$ Conferência me enxergava como um jovem que havia adquirido experiências e que me encontrava mais apropriado do debate das políticas públicas de juventude. Isto me deu maior segurança para pedir a palavra e para ocupar espaços de articulação e proposição dentro do grupo de trabalho sobre participação. Sinto-me parte responsável pela resolução 2 aprovada no eixo 5, no GT participação.

67 Vide Anexo J.

68 Adaptado de CRIVELARO, 2013. 
Em suma, havia perdido o medo e os receios presentes durante o debate de 2008, e me sentia mais próximo do tema, para debater, divergir e fazer defesas.

Ao observar outros grupos juvenis, organizados de modo diferente da PJ ainda que a articulação da PJ tenha adquirido contornos diferentes da $1^{\mathrm{a}}$ para a $2^{\mathrm{a}}$ edição -, muito me incomodava chegar a esta edição e não ter a clareza de quais as pautas que seriam discutidas e defendidas pela Pastoral. A questão da defesa da vida, em virtude da Campanha Nacional Contra a Violência e Extermínio dos Jovens, fez com que tivéssemos atuação em propostas que se aproximavam da temática da campanha. Porém, ao comparar a PJ com outros grupos, achava tudo muito solto e pouco orientado. Hoje, porém, vejo um certo devir nesta maneira de trabalhar, contrariando a prática de alguns grupos políticos juvenis que agem como as bancadas partidárias no Congresso Nacional que votam seguindo orientação do partido.

A realização desta edição me aproximou dos jogos políticos para eleição de delegados tanto em âmbito regional - Campinas - quanto na etapa estadual. Nos dois espaços, juntamente com outros jovens, assumi o papel de articular e projetar a eleição de delegados da pastoral para as etapas subsequentes. Isto não foi tarefa fácil, uma vez que, mesmo dentro do grupo, as relações de poder eram tensionadas pela escolha dos delegados que seriam nossos representantes na etapa nacional. Tanto os acordos, como as possíveis articulações políticas com partidos serviram de estopim para divisão do grupo da PJ na etapa estadual.

Deixei a $2^{a}$ Conferência Nacional com duas convicções para continuidade da caminhada: queria ser presidente do Conselho Municipal de Juventude, que havia sido criado há pouco tempo, e que esta seria minha última participação como delegado em uma conferência nacional de juventude.

\subsection{3 - $\quad \underline{3^{a} \text { Conferência Nacional de Juventude }}$}

Realizada de 16 a 19 de dezembro de 2015, no estádio Mané Garrincha, em Brasília, a $3^{a}$ Conferência Nacional teve como tema "As várias formas de mudar o Brasil" e como objetivo:

Atualizar a agenda da juventude para o desenvolvimento do Brasil, reconhecendo e potencializando as múltiplas formas de expressão juvenil, 
além de fortalecer o controle a todas as formas de preconceito. As propostas e resoluções da etapa nacional servirão de subsídio para a elaboração do Plano Nacional de Juventude. (BRASIL. SECRETARIA NACIONAL DE JUVENTUDE, 2015)

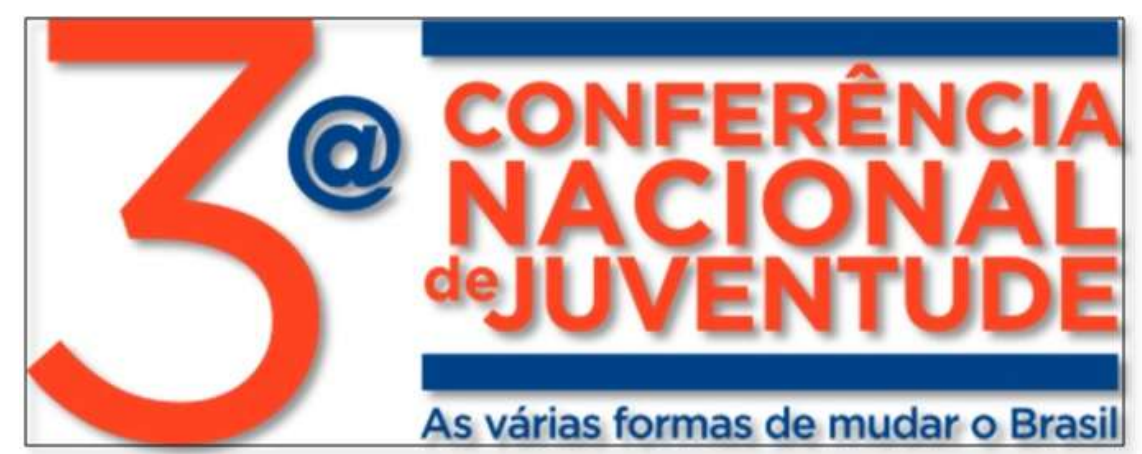

Figura 5 - Identidade visual da $3^{\text {a }}$ Conferência Nacional de Juventude Fonte: SNJ, 2015.

O tema, no bojo da multiplicidade cultural e social atribuída à juventude, propõe diferentes caminhos de consolidação das políticas públicas de juventude. A temática remete também às manifestações de junho de 2013, quando os veículos de comunicação e a população tinham dificuldades de identificar quais eram as demandas e as lideranças dos protestos que marcaram o país. Novamente o tema reivindica ao jovem o papel de protagonista, que em sua multiplicidade teria ou poderia realizar várias ações para ajudar a transformar o país.

Como primeira conferência realizada após a aprovação do Estatuto da Juventude, esta edição esteve organizada tematicamente a partir dos onze eixos do EJ, conforme exposto no quadro 7.

\begin{tabular}{|c|c|}
\hline Edição & $3^{a}$ Conferência Nacional de Juventude (2015) \\
\hline Tema & As várias formas de mudar o Brasil \\
\hline Lema & 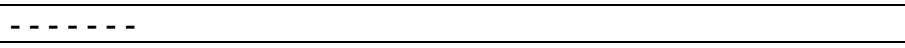 \\
\hline Temas gerais (eixos) & $\begin{array}{l}\text { I - Direito à Cidadania, à Participação Social e Política e à } \\
\text { Representação Juvenil; } \\
\text { II - Direito à Educação; } \\
\text { III - Direito à Profissionalização, ao Trabalho e à Renda; } \\
\text { IV - Direito à Diversidade e à Igualdade; } \\
\text { V - Direito à Saúde; } \\
\text { VI - Direito à Cultura; } \\
\text { VII - Direito à Comunicação e à Liberdade de Expressão; } \\
\text { VIII - Direito ao Desporto e ao Lazer; } \\
\text { IX - Direito à Sustentabilidade e ao Meio Ambiente } \\
\text { X - Direito ao Território e à Mobilidade; } \\
\text { XI - Direito à Segurança Pública e ao Acesso à Justiça. }\end{array}$ \\
\hline $\begin{array}{l}\text { Temas para os } \\
\text { grupos de trabalho }\end{array}$ & $\begin{array}{l}\text { Os grupos de trabalhos foram substituídos pelos eixos temáticos, } \\
\text { organizados em três momentos, cada um com três rodadas. }\end{array}$ \\
\hline
\end{tabular}

Quadro 7 - Temário e eixos da $3^{a}$ Conferência Nacional de Juventude 
Esta edição, onde estive mais uma vez como delegado, inovou com a proposição de uma plataforma digital, que permitia ao interessado na temática se cadastrar, fazer apontamento de propostas e ser eleito delegado para a etapa nacional, de acordo com o grau de interação alcançado a partir da aceitação de suas propostas e interação com outros usuários. A plataforma, ainda que idealizada para atrair jovens não inseridos em grupos tradicionais de participação juvenil, e outros não dispostos à inserção nas etapas presenciais, de certa forma conseguiu isto. No entanto, serviu como espaço para eleição direta de jovens oriundos de espaços tradicionais que percebiam agora uma forma mais fácil de chegar à etapa nacional, sem que precisassem enfrentar as tensões das etapas presenciais, podendo participar livrando-se dos enfrentamentos comuns até a chegada da etapa nacional.

Outro ponto que vejo como avanço é a proposição regimental de cotas mínimas de $50 \%$ para mulheres entre os delegados eleitos das etapas preparatórias até a etapa nacional, bem como a proposta de recortes raciais, tendo em vista os dados estaduais do IBGE sobre a população, que no caso da conferência se autodeclarou negra, amarela ou parda.

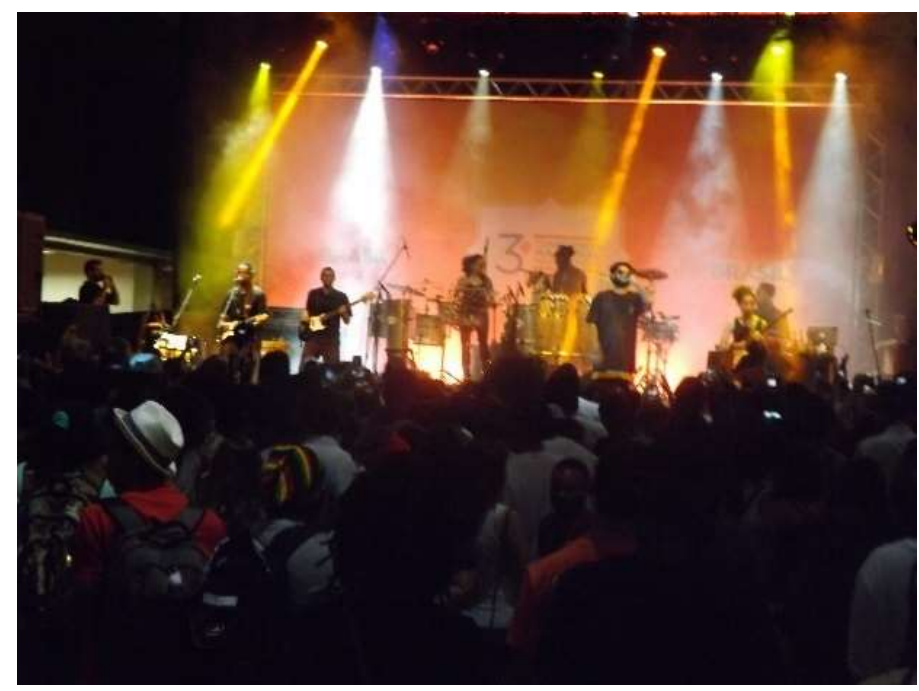

Figura 6 - Show durante a $3^{\text {a }}$ Conferência Nacional de Juventude

Em termos metodológicos houve também inovação. Os tradicionais grupos de trabalhos organizados por eixos, nos quais cada participante acompanhava apenas um tema, deu lugar à metodologia denominada café inglês. Nela os 11 eixos foram divididos em três momentos ${ }^{69}$, cada um deles com três rodadas. Em cada momento,

69 O primeiro momento contou com 3 eixos, enquanto os momentos 2 e 3 contaram com 4 eixos cada. Vide metodologia no Anexo $\mathrm{K}$ entregue aos participantes durante os momentos de eixos temáticos. 
até 8 participantes eram dispostos em mesas redondas, cuja temática era identificada pela cor da toalha, e um deles era eleito como anfitrião da mesa. Diferentemente dos demais, o eleito como anfitrião permanecia na mesa durante as três rodadas, tendo a responsabilidade de apresentar aos membros da mesa, a cada rodada, os pontos e as propostas escolhidas na rodada anterior. Aos demais participantes, que tinham como obrigatoriedade a mudança de mesa, era permitido permanecer na mesma temática ou transitar por outras ocorrendo naquele momento.

A cada rodada, as três propostas eleitas na mesa recebiam pontuações com pesos diferenciados, e que eram cumulativos. Ao concluir o momento, as nove propostas mais votadas no conjunto das mesas redondas estavam classificadas para a última votação, integrando o documento final da $3^{a}$ Conferência Nacional.

Esta edição contou também com o Manifesta definido como "processo para promover o reconhecimento e a visibilidade de manifestações juvenis em múltiplas linguagens e formas de expressão, durante as diferentes etapas" (BRASIL. SECRETARIA NACIONAL DE JUVENTUDE, 2015). Em resumo, o Manifesta era um conjunto de manifestações de espaços destinados a projeções, apresentações, instalações e experimentos, vivências e reflexões e de comunicação colaborativa que aconteciam durante a programação da etapa nacional.

Ao participar desta terceira edição, pude observar problemas na emissão das passagens aéreas, indisponibilidade de vagas em hotéis e conflito pelo uso do espaço entre o governo do DF e a comissão organizadora. Em função disso, um dos períodos destinados à programação quase não foi utilizado, ficando os participantes impedidos de adentrarem o recinto até que os conflitos fossem solucionados. Outro problema foi a não previsão da leitura e aprovação do regimento interno na programação da conferência. Estas e outras dificuldades enfrentadas pelos delegados eleitos contribuíram para aumentar a tensão e acirrar as disputas de poder entre eles e os grupos e coletivos presentes.

Ao término desta conferência, foram aprovadas três resoluções prioritárias e um conjunto de 99 resoluções ${ }^{70}$ oriundas dos eixos temáticos. Para chegar às 3 prioritárias, repetiu-se a metodologia da primeira edição, em que as propostas aprovadas nos eixos temáticos foram dispostas em totens. Cada delegado possuía três adesivos azuis e nove adesivos vermelhos. Os adesivos azuis eram colados

70 Para conhecer as Resoluções aprovadas na $3^{\text {a }}$ Conferência Nacional de Juventude, vide Anexo L. 
simbolizando o voto dos delegados para eleger as três propostas que julgavam prioritárias. Já os adesivos vermelhos foram colados em propostas que os delegados viam como importantes, porém não prioritária. Nesta edição, o número de propostas prioritárias foi menor que nas anteriores, o que foi outra mudança importante de organização. Ao término foram eleitas como demandas prioritárias as seguintes propostas $^{71}$ :

- Segurança: Não à redução da maioridade penal, pelo cumprimento efetivo das medidas previstas no Estatuto da Criança e do Adolescente (ECA).

- Território: Ampliar e acelerar o processo de Reforma Agrária e regularização fundiária, bem como o reconhecimento e demarcação de terras pertencentes a povos e comunidades tradicionais, em especial das terras indígenas e quilombolas, acabando com as práticas forçadas de remoção de seus territórios. A medida visou viabilizar a regularização da documentação de assentamentos já existentes, permitindo que os jovens tivessem condições de permanecer ou regressar as suas terras originais, e serem assim contemplados pelos programas, projetos e ações para a juventude rural.

- Participação: Garantir a implantação do Sistema Nacional de Juventude composto por órgãos gestores, conselhos e fundos de políticas públicas de juventude, nas três esferas administrativas. O fundo nacional de juventude funcionará com repasses fundo a fundo definidos percentualmente entres os três entes federados para direcionar as políticas e ações para a juventude em âmbito nacional, estadual e municipal.

Diante disto, quero observar, para concluir a breve exposição sobre esta edição, que as propostas no eixo participação e segurança retomam pontos que foram abordados e apresentados como prioritários nas outras duas edições.

Para mim, este é um indicativo da dificuldade encontrada pela juventude em consolidar as propostas prioritárias em políticas públicas implementadas e assumidas na agenda governamental. Conforme problematizado por Fonseca (2006), acredito que esta questão está associada à diferenciação entre governados e governos, segundo a qual aos governos é dada maior importância, sendo estes considerados como mais capacitados para pensar as políticas por possuírem conhecimento técnico.

71 As propostas são anotações dos participantes, mas também estão disponíveis no site http://juventude.gov.br/conferencia/noticias/saiu-o-resultado-final-confira-as-tres-propostasprioritarias-da-juventude-brasileira-para-mudar-o-brasil. 
Nesta lógica, somos divididos em povo e público, e, ao sermos vistos como público, os governantes passam a assumir que à população atribui-se apenas o papel de destinatário das políticas.

Por mais que os espaços de participação como a conferência sejam abertos, sinto que é como se tivéssemos que aguardar a piedade dos governantes para, após o esforço de participação nas conferências, ainda termos que lutar para os pontos aprovados como prioritários enfim se consolidarem como políticas públicas. É como se, no espaço da democracia participativa, ao congresso nacional fosse atribuído caráter de participação mais importante, em detrimento da sociedade civil organizada presente nas conferências, vista como agente de participação menos importante, porque, mesmo após o seu indicativo, carece ainda de parecer técnico para que se avalie a possibilidade de implementação.

Ao fim desta etapa, havia um misto de inconformismo devido aos diversos problemas de ordem organizacional que a conferência teve, um sentimento de que tais problemas só aconteciam por se tratar de uma conferência de juventude, e que jamais ocorreriam em espaços de conferências já consolidadas, como a área da saúde. Talvez neste momento eu tenha assumido o papel de vítima e de juventude oprimida, cuja participação não é valorizada no campo das políticas públicas. Por outro lado, perpassava a impressão de missão cumprida e de um ciclo de vida, e de militância, que findava.

A seguir abordarei as etapas municipais realizadas no município de Santa Bárbara d'Oeste - SP. Desta forma, tomarei por base para o estudo algumas narrativas pensadas como pesquisador participante nas edições municipais realizadas em 2008, 2011, 2014 e 2015.

\subsection{As Conferências Municipais de Juventude em Santa Bárbara d'Oeste - SP}

Segundo o IBGE (2010), em Santa Bárbara d'Oeste os jovens correspondem a 48.472 pessoas, possuem entre 15 e 29 anos, correspondendo a $26,9 \%$ da população barbarense. 
Tabela 4 - População jovem em Santa Bárbara d'Oeste

\begin{tabular}{|c|c|c|c|c|}
\hline $\begin{array}{c}\text { Faixa etária } \\
\text { (anos) }\end{array}$ & $\begin{array}{c}\text { Homens } \\
\text { (hab.) }\end{array}$ & $\begin{array}{c}\text { Mulheres } \\
\text { (hab.) }\end{array}$ & Total (hab.) & $\begin{array}{c}\% \text { na pop. } \\
\text { jovem }\end{array}$ \\
\hline $15-19$ & 7.503 & 7.406 & 14.909 & 30,8 \\
\hline $20-24$ & 8.536 & 8.193 & 16.729 & 34,5 \\
\hline $25-29$ & 8.537 & 8297 & 16.834 & 34,7 \\
\hline
\end{tabular}

Fonte: IBGE, 2010.

Juridicamente, a juventude passa a ser título e foco direto das leis municipais a partir de 2010. A partir de então, foram quatro leis, conforme aponta o Quadro 8, e alguns decretos, sendo que estes versam sobre a posse das gestões do Conselho Municipal de Juventude (CoMJuv), bem como a convocação das Conferências Municipais de Juventude.

\begin{tabular}{|l|l|}
\hline $\begin{array}{l}\text { Lei } \\
\text { Municipal }\end{array}$ & Ementa \\
\hline $3170 / 2010$ & $\begin{array}{l}\text { Institui a Semana Municipal da Juventude Barbarense, no município de } \\
\text { Santa Bárbara d'Oeste e dá outras providências }\end{array}$ \\
\hline $3204 / 2010$ & $\begin{array}{l}\text { Autoriza o município a participar do programa PROJOVEM Trabalhador } \\
\text { “Juventude Cidadã" no âmbito do Ministério do Trabalho e Emprego bem } \\
\text { como a firmar termo de parceria com organização da sociedade civil de } \\
\text { interesse público e dá outras providências }\end{array}$ \\
\hline $3309 / 2011$ & $\begin{array}{l}\text { Dispõe sobre as Políticas Públicas de Juventude, cria o Conselho } \\
\text { Municipal de Juventude, o Plano Municipal de Juventude e a Conferência } \\
\text { Municipal de Juventude e dá outras providências }\end{array}$ \\
\hline $3597 / 2014$ & Cria o Fundo Municipal da Juventude, dando outras providências \\
\hline
\end{tabular}

Quadro 8 - Leis Municipais com a juventude como tema e público alvo

Penso que a juventude se tornou foco destes dispositivos jurídicos a partir da realização das conferências municipais de juventude. Das quatro leis em vigor no município, duas - as leis n. ${ }^{\circ} 3309 / 2011$ e a 3597/2014 - versam sobre propostas apresentadas ao longo das duas primeiras conferências municipais de juventude. A lei municipal n. ${ }^{\circ} 3170 / 2010$ foi proposta ao governo municipal pela Pastoral da Juventude, após a realização do Dia Nacional da Juventude (DNJ) diocesana realizado na cidade em 2009.

Passados cinco anos da criação da primeira lei municipal que refere diretamente aos jovens, a muito custo e pela dedicação dos conselheiros municipais de juventude, foram realizadas seis edições da Semana Municipal de Juventude, contando, inclusive, com debate entre os candidatos a prefeito na edição de 2010 , e em 2015 acontecendo dentro de duas escolas ocupadas contra a reorganização escolar em São Paulo.

O CoMJuv está em sua segunda gestão, sempre presidido pela sociedade civil, ou seja, por jovens oriundos de grupos, coletivos ou associações que, em tese, não 
estão diretamente ligados à estrutura do poder público, considerando que a lei que o criou impede que os representantes da sociedade civil tenham vínculos empregatícios na administração municipal. Desde então, busca constituir-se como um espaço de debate, diálogo, de apresentação e reivindicação de demandas juvenis. Entre as suas principais dificuldades observo a falta de diálogo com o poder público, sendo que mesmo, ao ser procurado, em especial no que se refere ao poder executivo, nega-se ao debate. Constituem-se também dificuldades a falta de recursos financeiros para desenvolvimento de suas atividades e reconhecimento por parte do público que representa.

De modo geral, o CoMJuv, conforme a redação da lei que o instituiu, é um "órgão autônomo, permanente e consultivo", que conta em sua composição com 10 representantes do poder público e 20 da sociedade civil. Encontra-se em atividade devido aos esforços despendidos pelos representantes da sociedade civil, sendo muito rara, ou ainda pequena, a participação do poder público.

O Fundo Municipal de Juventude (FuMJuv) instituído em 2014 não está em funcionamento, e o teor do projeto de lei apresentado e aprovado gerou várias discussões, dentro do CoMJuv e com o poder público. Para nós que fazemos parte do CoMJuv, a redação do projeto não contempla o proposto e tem dificultado inclusive sua gestão. Na minha visão. como conselheiro e militante, e na de jovens que são militantes na área das políticas públicas de juventude no município, a gestão do mesmo deveria ficar sob a responsabilidade da Coordenadoria Municipal de Juventude e do Conselho Municipal de Juventude, diferentemente do que ocorre na atualidade, em que a Secretaria da Fazenda, que deveria responder apenas por sua gestão técnica, é responsável pelo funcionamento do Fundo, cabendo ao Conselho apenas sua anuência.

Em 2014, através de lei que prevê a reforma administrativa nas secretarias e cargos do poder executivo, foi criada, na estrutura da Secretaria de Governo, a Divisão de Juventude, que passou a ser designada como Coordenadoria de Políticas Públicas de Juventude, após lei aprovada na Câmara Municipal. Este órgão seria o responsável pela coordenação e gestão das políticas públicas de juventude, porém apresenta uma série de limitações, entre as quais ter apenas um profissional para pensar e executar as propostas de políticas públicas de juventude na cidade. A criação deste órgão também foi uma reivindicação das Conferências Municipais de Juventude. Porém, segundo proposta que apresentei na época, o órgão contaria com quatro pessoas. 
A partir da instituição da lei municipal n. ${ }^{\circ}$ 3309/2011, estão previstas a existência de um Plano Municipal de Juventude, concebido como uma política municipal que apresentaria as políticas públicas de juventude a serem desenvolvidas no período de cinco anos, e também as Conferências Municipais de Juventude instituídas como espaço para o diálogo entre o poder público e a sociedade civil, com realização a cada dois anos, bem como a eleição para os representantes da sociedade civil do CoMJuv.

Considerando a importância das Conferências Municipais para a instituição de dispositivos jurídicos, bem como de dispositivos produtores de jovens, juventude e participação, a seguir apresentarei ${ }^{72}$ cada uma das quatro edições realizadas até aqui.

\begin{tabular}{|l|l|c|c|}
\hline Ano & Tema & $\begin{array}{c}\text { Integrante da } \\
\text { etapa nacional }\end{array}$ & $\begin{array}{c}\text { Número de } \\
\text { participantes }\end{array}$ \\
\hline 2008 & Levante a sua bandeira & Sim & 150 \\
\hline 2011 & Conquistar direitos, desenvolver o Brasil & Sim & 162 \\
\hline 2014 & Juventude criando espaços de participação & Não & 22 \\
\hline 2015 & As várias formas de mudar o Brasil & Sim & 100 \\
\hline
\end{tabular}

Quadro 9 - Conferências Municipais de Juventude realizadas em Santa Bárbara d’Oeste

\subsection{1 - $\underline{1}^{\text {a }}$ Conferência Municipal de Juventude: Levante sua bandeira}

Realizada em 27 de janeiro de 2008, no Centro Atenção Integrada à Criança (CAIC) Irmã Dulce, a primeira edição da Conferência Municipal de Juventude começou a ser preparada em dezembro de 2007. Esta edição contou com a participação de 150 pessoas, divididas em sete grupos de trabalhos. Nesta edição foram identificados 20 desafios e 42 soluções (Anexo M) que, para os organizadores e participantes, visavam à superação das necessidades da juventude barbarense.

\begin{tabular}{|l|l|}
\hline Edição & $1^{\text {a }}$ Conferência Municipal de Juventude (2008) \\
\hline Tema & Levante sua bandeira! \\
\hline GTs & GT 1 - Cidade e Meio Ambiente; \\
& GT 2 - Cultura, Esporte, Turismo e Tempo Livre; \\
& GT 3 - Drogas; \\
& GT 4 - Educação; \\
& GT 5 - Família; \\
& GT 6 - Sexualidade, Diversidade e Preconceito; \\
& GT 7 - Trabalho. \\
\hline
\end{tabular}

Quadro 10 - Temário e GTs $1^{\text {a }}$ Conferência Municipal de Juventude

72 As seções que seguem foram construídas a partir de minhas memórias de participação nas edições das Conferências Municipais, bem como consulta aos relatórios finais de cada uma das edições. 
Esta conferência foi solicitada ao poder público por representantes da Pastoral da Juventude, os quais se constituíam como base de apoio a um representante do poder legislativo após participar da etapa municipal no município de Santos. Esta solicitação através de protocolo causou grande alvoroço na Secretaria de Governo, por não saberem ao certo, na época, do que se tratava. Para sua realização, após reunião aberta aos movimentos juvenis, realizada na Câmara Municipal, constituiu-se uma comissão organizadora formada por 14 pessoas, sendo 10 oriundas da sociedade civil e 4 oriundas do poder público. Passamos as festividades de Natal e Ano Novo sonhando com a organização e realização desta conferência. Víamos naquele momento a grande oportunidade para inserir a juventude nos debates políticos na cidade, o que para nós não havia acontecido até o presente. Por isso, esta edição teve para nós um caráter de marco, nos debates das políticas públicas de juventude no município.

Fomos aprendendo a organizar uma conferência, conforme aprendíamos nesta prática o que era uma conferência. Praticamente nenhum de nós havia participado de uma conferência municipal, como etapa preparatória para a fase nacional. Era tudo muito novo, e tínhamos total confiança na possibilidade de transformar as proposições da conferência municipal em políticas públicas. O desejo nosso era pensar o como esta cidade poderia ser boa também para o jovem, a partir das respostas para suas necessidades e das propostas por eles apresentados. $O$ ar da novidade, da rebeldia e do desejo nos perpassava a cada momento desde o estopim em Santos para realizar a conferência em Santa Bárbara d'Oeste, até o dia de sua realização, e continuou depois com o desejo de alguns de chegar até a etapa nacional.

Durante o processo de organização desta conferência, em virtude do apoio da prefeitura, da Câmara dos Vereadores e dos contatos que possuíamos, tivemos grande apoio nas mídias da cidade para divulgação e propagação da conferência. Nossa grande surpresa, e também do facilitador da conferência nacional que esteve presente para fazer a abertura e contextualização inicial do evento, foi acordar e ver a atividade como matéria principal e de capa do Jornal Diário de Santa Bárbara.

Os participantes eram oriundos de 21 organizações sendo elas: Associação Brasileira de Incentivo a Projetos Empresariais (ABRIMPE), Associação Pró-Ambiente de Santa Bárbara (APASB), Associação de Amigos dos Bairros da Zona Sul (ASABZSUL), Assembleia de Deus- Ministério Belém, Câmara dos Vereadores, Comunidades Eclesiais de Base (CEBs), Centro de Referência em Referência Sexual 
e Reprodutiva, Congregação Cristã do Brasil, Conselho de Leigos, Coordenadoria Municipal de DST-AIDS, Espaço Vida e Cidadania, Fórum da Cidadania, Grupo de Instrutores de Referência a Saúde Sexual de Adolescente (Grupo IRSSA), Guarda Mirim, Grupo de Adolescentes Instruindo Sexualidade e Prevenção (Grupo AVISP), Igreja Batista do Caminho (Tenda), Juventude do Partido da Social Democracia Brasileira (JPSDB), Juventude do Partido dos Trabalhadores (JPT), Movimento Cultural de Conscientização Juvenil (MCCJ), Pastoral da Juventude (PJ) e Serviço Social em Promoção da Cidadania Imaculada Conceição (SSPCIC). Dentre tais grupos, organizações e coletivos, dois se destacaram pelo número de participantes: a PJ e o grupo IRSSA.

A programação do evento contou com apresentações culturais, momento de abertura com participação de autoridades políticas, GTs e plenária final. Cada um dos GTs contava com pessoas que eram referência nas temáticas em Santa Bárbara d'Oeste, cujo objetivo era instigar os jovens a debater os assuntos e apresentar os desafios e as soluções para sua superação.

Dentre as propostas, foram destaque a "Criação da Coordenadoria Municipal de Juventude" e do "Conselho Municipal de Juventude". Esta última, após acordo político entre os representantes do poder público e a comissão organizadora, foi denominada de Fórum Permanente de Juventude, com caráter diferenciado do Conselho, sem a necessidade de instituição por lei. Este acordo nunca agradou a mim e a outros companheiros de militância da Pastoral da Juventude (PJ), que continuamos reverberando esta proposta, como ela foi apresentada durante a conferência municipal.

Como etapa preparatória, se elegeram 35 delegados para participação nas etapas regional, realizada em Campinas, e estadual, realizada em São Paulo. Para a etapa nacional, foram eleitos 4 representantes.

Este processo de eleição e escolha dos delegados que nos representariam, em especial na etapa nacional, foi marcado por tensões e disputas de poder. Em tese, aqueles que tinham a liderança dos grupos mais fortes, quando considerado o número de participantes, tinham maior visibilidade e poder de competição para pleitear esta representação. Embora tenhamos atingido o proposto com os 4 delegados eleitos, este processo foi marcado por rivalidades políticas, e rebeldia diante de votos que foram divididos para atingir o objetivo do município em eleger 4 delegados para a etapa nacional. 
O relatório desta edição da Conferência apresenta a seguinte avaliação:

De acordo com a avaliação da comissão organizadora e com algumas falas dos/as participantes durante e pós-conferência, a expectativa de proporcionar um espaço de discussões sobre alguns dos temas relacionados à juventude e de construir coletivamente propostas e encaminhamentos (desafios e soluções) para as próximas etapas da Conferência Nacional foram alcançadas com grande sucesso. Outro ponto importante foi a aprovação e encaminhamento da proposta de implementação no município da Coordenadoria de Juventude e de um Fórum Permanente de Juventude, garantindo a continuidade da discussão e implementação das propostas, debates de outros temas e necessidades da juventude barbarense através da parceria que teve grande êxito durante a conferência: Executivo/ Legislativo/ Sociedade Civil. (SANTA BÁRBARA D'OESTE, 2008, p. 2)
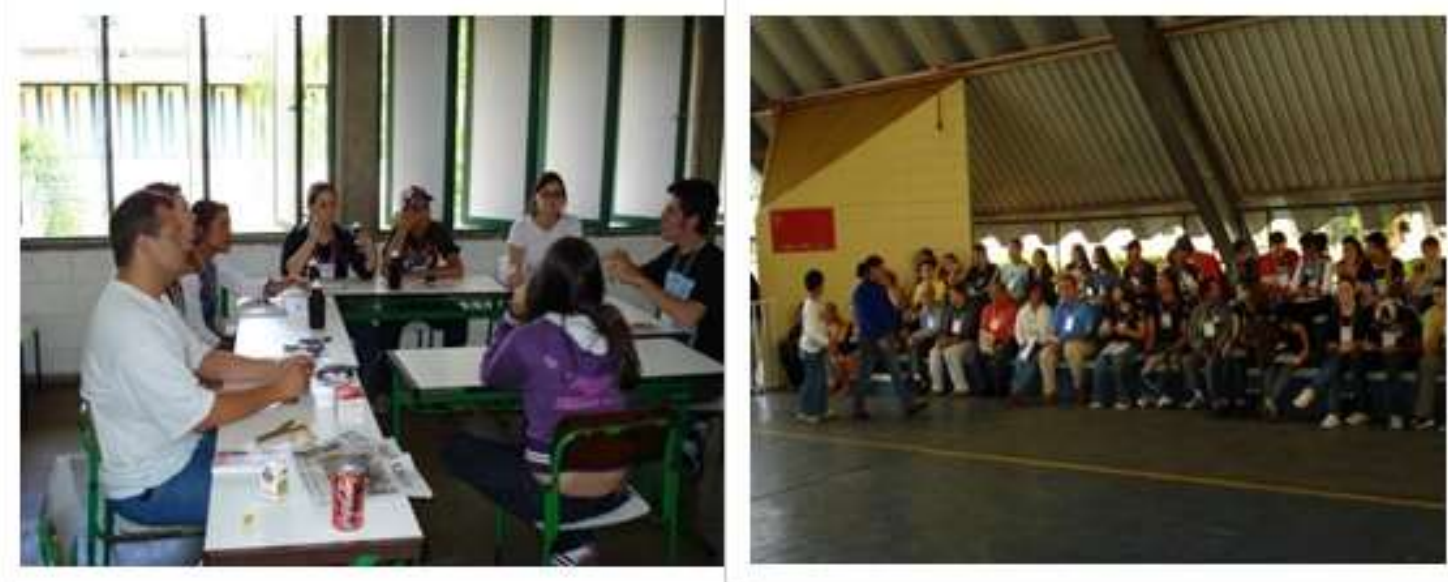

Figura 7 - GT Educação (esquerda) e Momento de abertura da $1^{\mathrm{a}}$ Conferência Municipal (direita) ${ }^{73}$

O trecho acima, retirado do item "avaliação" do relatório final desta edição apresenta a alteração textual da proposta de criação do Conselho Municipal de Juventude, que foi transformado atendendo ao proposto pela administração municipal para um Fórum Permanente de Juventude. Após a conferência, fomos críticos a esta proposta, considerando a diferença entendida entre estes dois espaços de participação. Para nós, no que tangia ao vínculo entre poder público e sociedade civil, esta relação seria mais direta a partir da criação do Conselho com respaldo legal como órgão consultivo e deliberativo na proposição de políticas públicas de juventude. Já o Fórum possuía um cunho mais aberto e sem o caráter consultivo ou até mesmo deliberativo que o Conselho teria. Víamos, enquanto sociedade civil, que não necessitávamos do poder público para constituir um Fórum Permanente de Juventude. Esta medida poderia se efetivar a partir do desejo de coletivos juvenis da sociedade civil.

${ }^{73}$ Fotos do acervo das conferências municipais de juventude, 2008. 
Ao retratar os meus sentimentos e vivências nesta edição, acredito nas palavras de Dias (2002, p.12):

A experiência é um fato político por excelência, acontece enquanto história
como obra de seres humanos cheios de limitações e de capacidades,
carregados de entusiasmos e de dúvidas. Quem se lança na experiência
abandona a tranquilidade, transita permanentemente entre espaços plenos
de indignação e outros feitos de conquistas, que sempre alargam as fronteiras
do possível. A experiência confere acesso aos resultados, permite a
construção do poder, sendo este compreendido com um conjunto de recursos
que, articulados entre si, amplia o campo de possibilidades para a existência
de todos.

Penso que, como seres humanos cheios de limitações, fomos capazes de enxergar a potência em nós disparada por nosso desejo e ao mesmo tempo por nossa indignação com uma cidade que, a nosso ver, não pensava com o jovem. E mesmo diante das incertezas que encontraríamos em uma trajetória que se afigurava para nós como novidade, fomos carregados pelo entusiasmo e assumimos a vida enquanto potência, rebeldia que se faz enquanto espaço de criação e ousadia.

\subsection{2 - $\underline{2}^{\mathrm{a}}$ Conferência Municipal de Juventude: Conquistar Direitos, desenvolver o Brasil}

Em 4 de setembro de 2011, com a participação de 162 pessoas, foi realizada a $2^{\mathrm{a}}$ Conferência Municipal de Juventude de Santa Bárbara d'Oeste, etapa integrante e eletiva da $2^{\text {a }}$ Conferência Nacional de Juventude.

Convocada pelos decretos municipais n. ${ }^{\circ} 5151$ e 5170/2011, esta edição contou com comissão organizadora formada por 16 integrantes, sendo 8 do poder público (4 do legislativo e 4 do executivo) e 8 representantes da Sociedade Civil, muitos dos quais estiveram envolvidos na organização da $1^{\text {a }}$ edição. 


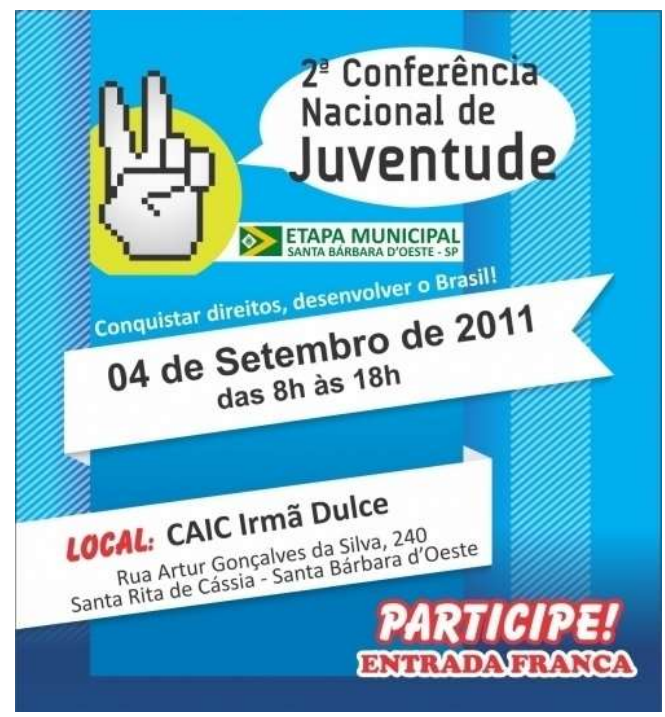

Figura 8 - Identidade visual da $2^{\text {a }}$ Conferência Municipal de Juventude Fonte: Relatório da $2^{\text {a }}$ Conferência Municipal de Juventude.

\begin{tabular}{|l|l|}
\hline Edição & 2 $^{\text {a }}$ Conferência Municipal de Juventude (2011) \\
\hline Tema & Conquistar direitos, desenvolver o Brasil. \\
\hline GTs $^{74}$ & GT 1 - Lei e Juventude; \\
& GT 2 - Juventude: Educação e Trabalho; \\
& GT 3 - Juventude: Cultura e Comunicação \\
& GT 4 - Juventude: Cidade, Campo e Transporte Público; \\
& GT 5 - Juventude e Meio Ambiente; \\
& GT 6 - Juventude e Saúde; \\
& GT 7 - Juventude e Povos Tradicionais; \\
& GT 8 - Juventude: Esporte, lazer e tempo livre; \\
& GT 9 - Juventude e vida segura; \\
& GT 10 - Juventude e diversidade; \\
& GT 11 - Juventude e direito à participação. \\
\hline
\end{tabular}

Quadro 11 - Temário e GTs $2^{\mathrm{a}}$ Conferência Municipal de Juventude

Nesta edição, estavam previstos 11 GTs, porém, devido à escolha dos participantes, os jovens foram agrupados em 8 Grupos de Trabalho, os quais debateram os 5 eixos propostos pelo Regimento Interno Nacional. Além do debate do texto base nacional, foram elencadas 35 resoluções municipais das quais 15 foram apontadas como prioritárias (Anexo N).

Participaram desta edição 28 grupos/organizações/entidades/secretarias de nosso município: Câmara Municipal de Santa Bárbara d'Oeste, Comunidades Eclesiais de Base (CEBs), Conselho Municipal de Segurança (CONSEG), Demolay, estudantes das escolas Escola Irene de Assis Saes e Escola Técnica Estadual ETEC José Dagnoni - Centro Paula Souza, estudantes universitários, Fórum da Cidadania, Grupo de Dança Kairós, Grupo de Jovens “Jesus encontra jovens unidos” (JEJU), Grupo de Teatro "Em busca de um sorriso", Igreja Belém, Irmãs da Caridade

74 GTs propostos pela comissão organizadora que no dia da conferência foram reagrupados, permanecendo 8 salas de debates, que respeitaram as 11 temáticas. 
de Ottawa, Movimento Negro, Ordem dos Advogados do Brasil (OAB), Paróquia Imaculada Conceição, Paróquia Santo Antônio, Paróquia Senhor Bom Jesus, Pastoral da Juventude, Professores da Secretaria Estadual de Educação, Secretaria de Cultura e Turismo, Secretaria de Governo e Secretaria de Promoção Social.

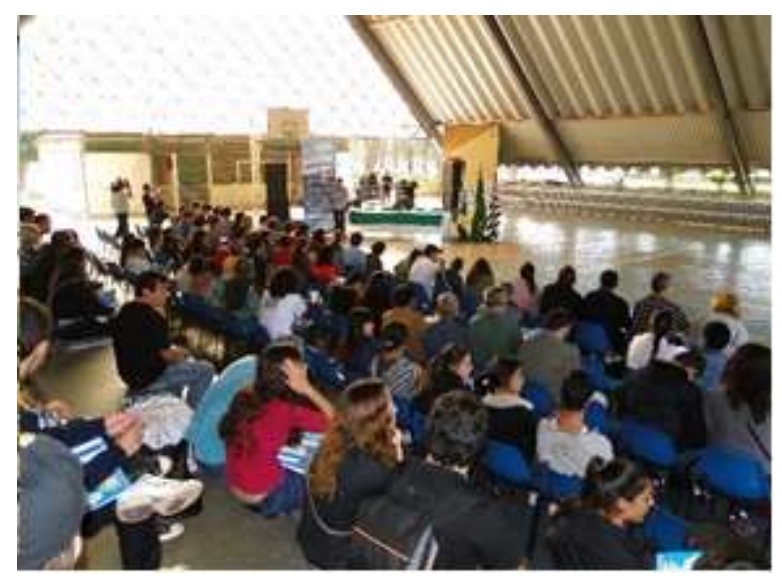

Figura 9 - Abertura da $2^{\text {a }}$ Conferência Municipal de Juventude Fonte: Acervo da Conferência Municipal de Juventude, 2011.

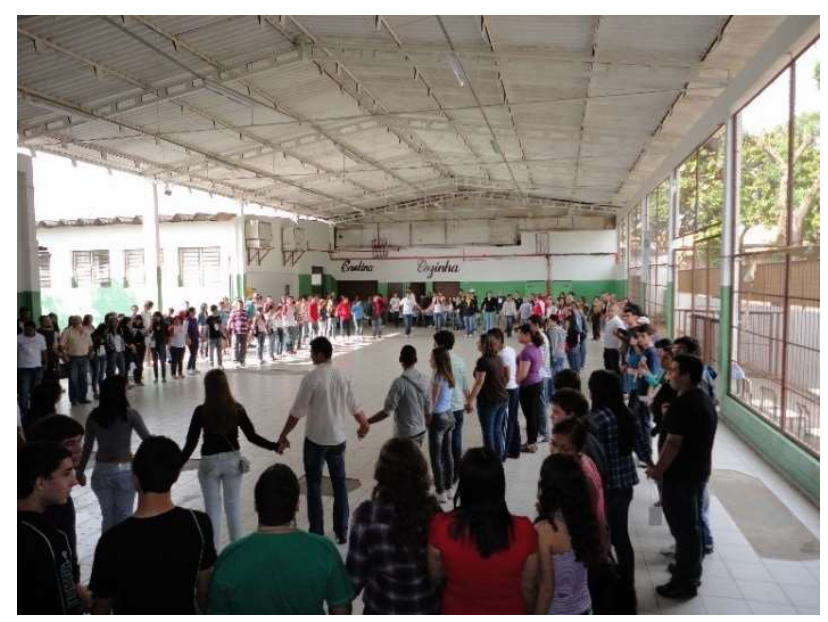

Figura 10 - Ciranda durante Conferência Livre realizada pela PJ Fonte: Relatório final da $2^{a}$ Conferência Municipal de Juventude.

Durante a abertura desta edição, o prefeito Mário Heins sancionou a Lei Municipal n. ${ }^{\circ} 3309 / 2011$, instituindo as políticas municipais de juventude, criando o Conselho Municipal de Juventude, bem como o Plano Municipal de Juventude e as Conferências Municipais de Juventude como evento bianual. Novamente a criação da Coordenadoria Municipal de Juventude foi apontada como demanda prioritária, porém, a mais votada dentre as propostas foi "Melhorar o transporte público municipal, aumentando a disponibilidade de integração de linhas pelo município, ampliando também os horários e bairros atendidos inclusive aos fins de semana, melhorando também as condições de uso e conforto dos veículos utilizados". A novidade nesta 
edição foi a realização da Conferência Livre realizada pela Pastoral da Juventude com 240 jovens crismandos ${ }^{75}$ das paróquias Imaculada Conceição e São Francisco de Assis. A Conferência Livre foi também utilizada como etapa preparatória e de divulgação para a etapa municipal.

Apesar de eleger 31 delegados para a etapa regional, apenas 22 estiveram presentes no município de Campinas, sendo os 22 indicados como delegados para a etapa estadual. Guarujá, município que recebeu a $2^{\mathrm{a}}$ Conferência Estadual, contou com a presença de 16 delegados indicados na fase estadual e, desses, 4 barbarenses foram eleitos para participar da etapa nacional.

Dentro da avaliação apresentada pela Comissão Organizadora Municipal nesta edição, acho pertinente destacar o observado quanto à conferência enquanto espaço de diálogo e participação da juventude: As propostas apresentadas mostram que, quando o espaço é aberto e com
um debate propositivo e de qualidade, a juventude participa. As formas de
manifestações são novas. Porém, isso não quer dizer que o jovem esteja
apático, mas sim transformando-se com a sociedade. Em suma, a sociedade
transforma o jovem, e o jovem transforma a sociedade. (SANTA BÁRBARA
D'OESTE, 2011, p. 34)

Agora é continuar a abrir espaços para os jovens não apenas em Conferência, mas transformar suas demandas em políticas públicas de juventude. E vamos em frente, que a luta está apenas se iniciando. Ainda há muito por fazer! (SANTA BÁRBARA D'OESTE, 2008, p. 34)

O que havia mudado para nós organizadores desta edição é que aquele grupo que, lá atrás, propôs a novidade da Conferência Municipal de Juventude agora tinha em sua bagagem a experiência da organização e da participação em todas as etapas da Conferência de Juventude. Para além disso, quem estava encarregado da função de articulador das políticas de juventude era uma pessoa do nosso grupo, o que facilitava o processo, porém nem sempre evitava tensões, em especial ao compararmos a potência emanada da juventude enquanto sociedade civil com a morosidade do poder público em atender as nossas proposições.

Se no começo da edição pensei várias vezes - Para que conferência se praticamente nada da $1^{a}$ foi posto em prática? - na continuidade começamos a enxergar a efetivação de algumas proposições feitas em 2008, entre as quais a

${ }^{75} \mathrm{O}$ termo jovens crismandos é utilizado em referência aos jovens da igreja Católica que fazem a preparação ao sacramento da Crisma. 
criação do Conselho Municipal de Juventude, que tomou posse durante a $2^{\text {a }}$ Semana Municipal de Juventude, cuja proposta foi nossa, enquanto Pastoral da Juventude.

As tensões ao longo do processo, em comparação com a primeira edição, foram menores e associo a isto o fato de os delegados que representaram a cidade estarem em grupos e coletivos juvenis ligados a escolas e igrejas. Porém de forma a não assumir esta militância no espaço da conferência, a ponto de produzirem enfrentamentos originados em diferenças entre os coletivos. Eles estavam lá muito mais por um desejo pessoal, do que por orientação ou proposição de um grupo ou coletivo. Embora quase todos tenham se inscrito como candidatos à etapa nacional, a definição dos quatro nomes se deu de forma muito tranqüila - não houve tanto tensionamento ou disputas como em 2008 -, ainda que as indicações tenham saído das lideranças do município.

\subsection{3 - $\quad \underline{3^{a} \text { Conferência Municipal de Juventude: Juventude criando }}$ espaços de participação}

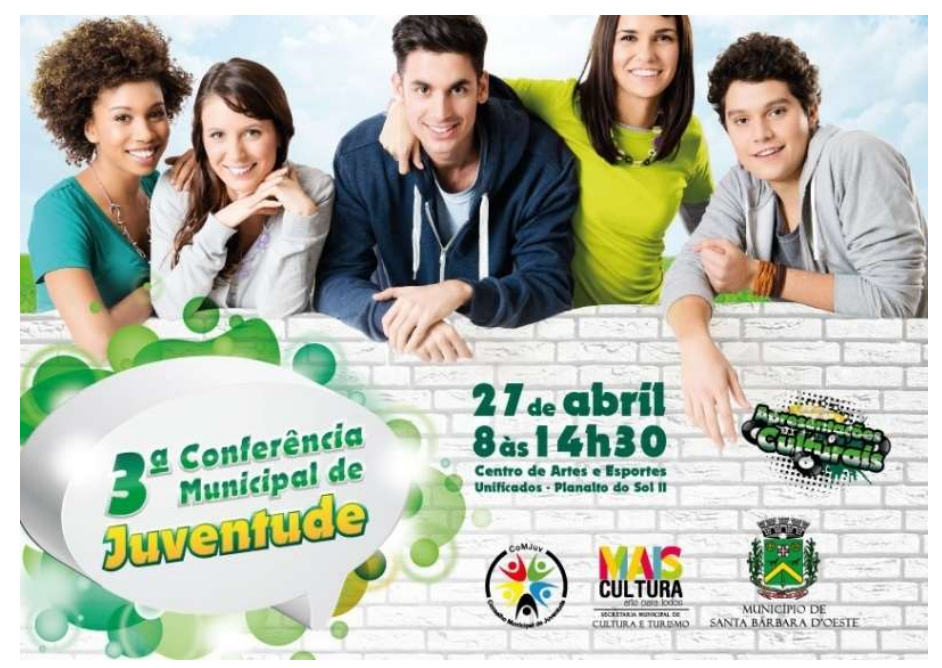

Figura 11 - Identidade visual da $3^{\text {a }}$ Conferência Municipal de Juventude Fonte: Relatório Final da $3^{\text {a }}$ Conferência Municipal, 2014.

Diferentemente das edições anteriores, a $3^{a}$ Conferência Municipal de Juventude, realizada no dia 27 de abril de 2014, no Centro de Esportes e Artes Unificados (CEU), não foi etapa integrante de edição nacional. Sua realização atendeu à lei municipal n. ${ }^{\circ} 3309 / 2011$, cujo objetivo era aprovar proposta de minuta para o 
Plano Municipal de Juventude, bem como a eleição da gestão do Conselho Municipal de Juventude (CoMJuv/ 2014-2016).

Esta foi a primeira edição em que a Divisão de Juventude estava em funcionamento como previsto em lei. Contou com a presença de 22 participantes, com vários vereadores circulando pelo espaço e foi também a única das edições realizadas que não contou com a presença do Prefeito.

Tendo em vista o pequeno número de participantes, os grupos de trabalho não foram realizados, assumindo um caráter de roda de conversas, nas quais, ao invés de revisão da proposta de minuta do Plano Municipal de Juventude, foi novamente feita a indicação de propostas por parte dos participantes, totalizando 33 propostas (Anexo O), conforme os eixos da minuta do projeto de lei em questão.

\begin{tabular}{|l|l|}
\hline Edição & $3^{\text {a }}$ Conferência Municipal de Juventude (2014) \\
\hline Tema & Juventude criando espaços de participação. \\
\hline GTs & GT 1 - Direito ao desenvolvimento integral: Educação, trabalho, \\
& cultura e comunicação; \\
& GT 2 - Direito ao território: cidade, campo, transporte, meio \\
& ambiente e comunidades tradicionais; \\
& GT 3 - Direito à experimentação e qualidade de vida: Saúde, \\
& esporte, lazer e tempo livre; \\
& GT 4 - Direito à diversidade e vida segura: segurança, valorização \\
& e respeito à diversidade e direitos humanos; \\
& GT 5 - Direito à participação e fortalecimento institucional.
\end{tabular}

Quadro 12 - Temário e GTs $2^{a}$ Conferência Municipal de Juventude

Os participantes eram oriundos de quatro grupos: conselheiros municipais de juventude, jovens participantes de grupos católicos, vereadores e estudantes secundaristas.

Se no período de realização da $2^{a}$ Conferência me ausentei do trabalho no período de uma semana para me dedicar à divulgação da Conferência, nesta edição, talvez pelo cansaço provocado por presidir o Conselho Municipal de Juventude, e pela tensão para que a prefeitura enfim a realizasse, não me envolvi na divulgação do evento.

A maioria de todos os envolvidos na organização das outras edições não fazia mais parte da organização. Esta conferência foi pensada em um momento de transição do atual grupo, que forma a gestão do Conselho Municipal de Juventude, e a primeira gestão que enfrentava o esgotamento e o desânimo atribuído por mim às diferenças de entendimento sobre a velocidade com que as coisas deveriam acontecer entre poder público e sociedade civil. Muitos jovens foram abandonando o 
processo de 2011 até 2014 por não observarem resultados concretos por parte do poder público diante de seus desejos enquanto jovem participante.

Ao observar a realização da edição de 2015 , notei que vários participantes que estiveram em 2014 têm agora um olhar de desânimo e decepção, que está diretamente relacionado ao número de participantes.

Como a edição de 2014 não possui um relatório final, a avaliação ficou limitada a conversas deste pesquisador e às reuniões do Conselho Municipal de Juventude, que em resumo questiona exatamente o pequeno número de participantes.

\subsection{4 - $\quad \underline{4^{a} \text { Conferência Municipal de Juventude: As várias formas }}$ de mudar o Brasil}

Convocada pelo decreto municipal n. $.^{\circ} 6518 / 2015$, a $4^{\text {a }}$ Conferência Municipal foi realizada de forma integrada no CEU e no Centro Integrado de educação pública (CIEP). Esta etapa preparatória da Conferência Nacional de Juventude contou com a presença de 100 participantes.

Sua programação foi variada, contando com mesa política de abertura, contextualização das políticas de juventude no município, apresentações culturais, oficina de grafite e roda de conversa para definição de propostas.

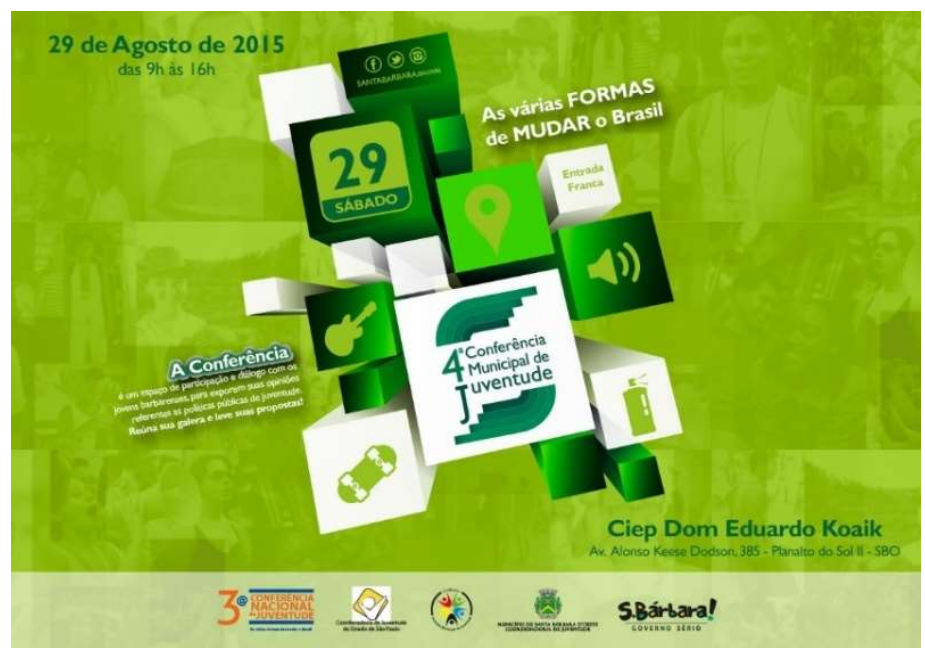

Figura 12 - Identidade visual da $4^{a}$ Conferência Municipal de Juventude

Fonte: Relatório da $4^{a}$ Conferência Municipal de Juventude, 2015.

Mais uma vez, os grupos de trabalhos foram abandonados, por opção da comissão de metodologia da conferência, sendo realizada em sua substituição uma 
grande roda de conversa, que debateu os desafios da juventude no município e elencou 22 propostas (anexo $\mathrm{P}$ ) para superação de tais desafios, considerando os 11 eixos do EJ.

Ao avaliar a $4^{a}$ edição no relatório final, a Comissão Organizadora Municipal assim definiu sua realização:

\begin{abstract}
Concluindo, pode-se dizer que a $4^{\mathrm{a}}$ Conferência Municipal de Juventude da cidade de Santa Bárbara d'Oeste foi um marco para as discussões de Políticas Públicas de nossa cidade, agregando aos legados deixados pelas conferências anteriores. Deste modo, a conferência é inserida como mecanismo de gestão de política social, no sentido de orientar e traçar diretrizes à gestão pública, como também à sociedade civil, às instituições, aos profissionais da área o qual culmina em estratégias adequadas para o enfrentamento nas diversas questões e demandas da juventude. (SANTA BÁRBARA D'OESTE, 2015, p. 15)
\end{abstract}

Para mim, a grande novidade nesta edição foi o aparecimento das demandas relacionadas ao público LGBT, sendo que muitos jovens se identificaram como homossexuais, inclusive solicitando a revisão do Plano Municipal de Educação no que tange à diversidade de gênero. Outra novidade foi a realização de pré-conferências por um grupo de jovens da Igreja Católica, na Escola Estadual Comendador Emílio Romi, Escola Estadual Fioravante Luiz Angolini e Escola Técnica (ETEC) José Dagnoni. Esta ação de divulgação e de preparação para a etapa municipal reverberou com a presença de vários estudantes secundaristas, oriundos em especial das duas Escolas Estaduais mencionadas, sendo que a maior parte dos presentes nesta edição eram estudantes secundaristas.

Nesta edição, o município contou com representantes na etapa regional, realizada em Limeira, e 22 representantes na etapa estadual realizada no município de Atibaia. Para a etapa nacional, foram eleitos 5 representantes, porém, devido a problemas pessoais, um representante acabou desistindo da participação.

Pela primeira vez, embora tenha participado de quase todas as reuniões da Comissão Organizadora Municipal (COM), optei por não estar neste espaço. Esta decisão estava atrelada ao fato de integrar a Comissão Organizadora Estadual (COE), o que demandava reuniões semanais em São Paulo. E também por compreender que, assim como o ciclo de outros companheiros que comigo estiveram na realização e idealização deste sonho se encerrou, agora era o meu momento de também encerrar este ciclo. Busquei em algumas ocasiões acompanhar a COM, porém o sentimento de que alguns equívocos foram cometidos nas outras edições me despertou o desejo de ver a Conferência Municipal agora construída por outras mãos. 
Olhar deste outro modo, deste outro lugar, foi satisfatório por perceber que a história continua a ser escrita, agora pela mão de novos escritores, que também desejavam este espaço.

\section{3 - Algumas reflexões a partir destes voos e pousos}

Ao pousar sobre minhas memórias e relatórios finais das conferências nacionais e municipais de juventude, penso serem possíveis novas reflexões. Hoje percebo que as conferências apresentam características diferentes, ao observar quem compõe a organização e quem participa no dia da conferência e, ainda, ao notar quem atua na organização e quem está como participante.

Embora não queira fixar lugares nestes espaços, teoricamente, jovens que possuem trajetória de militância apresentam uma possibilidade maior de estar nos espaços organizativos das conferências. Claro que, ao olhar para as quatro comissões organizadoras, consigo encontrar exceções, porém, quando observo como estas pessoas foram convidadas a compor a comissão organizadora municipal, percebo o quanto o convite está associado à participação dessas pessoas em posição de liderança nos espaços instituídos de participação juvenil. Neste contexto estão igrejas, escolas, partidos políticos ou entidades de classe.

Ao olhar para a etapa nacional, esse espaço fica ainda mais restrito, pois a COM, via de regra, é composta por pessoas que estão como conselheiros nacionais de juventude, espaço pouco acessível para aqueles jovens que não atuam em espaços instituídos de participação de juventude, ou que são coletivos e grupos juvenis com pouca visibilidade nacional. Saliento, porém, que boa parte destes jovens não se designa como militantes, mas reverberam o desejo de ser protagonistas.

Outro ponto que merece reflexão são os espaços de onde são oriundos os participantes. As possibilidades de um jovem militante que não está inserido em grupos e coletivos juvenis são maiores em uma etapa municipal, considerando que grande parte dessas etapas é aberta à livre participação, ou seja, como espaços de participação direta. As demais etapas passam a funcionar como participação representativa, e por isso não estariam disponíveis a todos os jovens, como na fase 
anterior. Em Santa Bárbara d'Oeste, em nenhuma das três edições integrantes da etapa nacional isto se constituiu como um problema. Isto porque, através dos acordos e negociações políticas, sempre conseguíamos o número de vagas próximo do número de interessados em estar nestas etapas e constituíamos uma das maiores delegações da Região Administrativa de Campinas.

Porém, em todas as etapas, o perfil de jovem esperado nas conferências é o de jovem militante. Isto pode ser visto, inclusive, a partir dos enunciados utilizados como tema em cada uma das edições que refletem um convite à militância. $\mathrm{Na}$ primeira edição, Levante sua bandeira, com um convite à juventude para militância, através da proposição de políticas públicas. Em 2011, Conquistar direitos, desenvolver o Brasil, um convite aos jovens que militaram na primeira edição, a serem agora protagonistas do desenvolvimento do país, o que se daria a partir da garantia de direitos à população jovem. A última edição, As várias formas de mudar o Brasil, me remete a uma tentativa de ampliar e diversificar a conferência para jovens que não estão em espaços de militância. Porém, para mudar o Brasil, é evocado um sentimento de necessidade de militância que desencadearia esta transformação.

Nas etapas nacionais, em virtude dos processos eletivos, o dito jovem militante pode ser encontrado com maior facilidade, no entanto, nas etapas municipais este contorno discursivo nem sempre é encontrado, possibilitando às conferências contornos para além do esperado e proposto por suas comissões organizadoras.

Esta diferença pode ser observada a partir do espaço de Santa Bárbara d'Oeste, pois em cada uma das edições foram eleitos 4 delegados para a etapa nacional. Nas duas primeiras edições, integrantes da etapa nacional, os eleitos para a representação, possuíam perfil de militante, estavam vinculados a grupos ou coletivos juvenis com projeção nacional no campo das políticas públicas de juventude, e ocuparam papel de destaque nas etapas municipais, como organizadores ou facilitadores de grupos de trabalho. A quarta edição destoa neste sentido, pois os jovens eleitos para a etapa nacional não eram ligados a grupos ou coletivos juvenis de expressão nacional. No entanto, estavam vinculados à comissão organizadora municipal, e tinham apoio dos coletivos, dos quais faziam parte, para chegarem à condição de delegado na etapa municipal. Aqui incluo o Conselho Municipal de Juventude, como um coletivo de participação juvenil na cidade.

Eu ter chegado, nas duas primeiras edições, à etapa nacional só foi possível por fazer parte da Pastoral da Juventude e por ter um grupo de pessoas organizadas 
que atuavam no espaço, no sentido de eleger-me delegado para a etapa nacional, além de estar na Comissão Organizadora Municipal. A partir da segunda conferência, posso afirmar que a estas características acrescentaram-se o conhecimento da dinâmica do funcionamento e ainda do vocabulário utilizado neste espaço de participação.

A conferência se configurou para mim como uma oportunidade para entender toda sua dinâmica de funcionamento, bem como as políticas públicas e os espaços participativos e representativos.

Desta forma, estes voos e pousos que ora faço me permitiram compreender que este espaço onde capturei, mas também fui capturado, no qual por vezes rejeitei as relações e acordos políticos e em outros momentos os ajudei a serem tecidos, foi o meu espaço formativo na compreensão da dinâmica do jogo e das tessituras políticas. Foram as conferências de juventude que me permitiram ampliar e conhecer os sentidos, assim como a dinâmica do jogo e das relações de poder, presentes desde o espaço municipal até o espaço nacional. Muitas vezes pude também compreender aquilo que estava escrito nas entrelinhas, aquilo que, mesmo não pronunciado, por vezes estava dito, e também olhar para os jovens como multiplicidade, e não como identidades rígidas e fixas.

Destaco que, neste espaço permeado pelas relações de poder, tal poder é encontrado de forma difusa, não fixa, sendo remodelado a todo instante. Nas conferências, o poder público não é o único reverberador das relações de poder, apesar de as conferências serem convocadas por ele que, por suas atribuições, ocupa posições que muitas vezes dão destaque a seus representantes. Esse poder se encontra e também se reverbera a partir da sociedade civil.

Se considerar estas relações de poder a partir da eleição de delegados à etapa nacional, a sociedade civil, por exemplo, sempre correspondeu a pelo menos $75 \%$ dos delegados municipais eleitos à etapa nacional.

Acho interessante problematizar também as relações desencadeadas internamente nos coletivos e grupos juvenis que participam deste espaço. Por exemplo, como já mencionado na questão do aborto, na primeira conferência a orientação da PJ foi de cuidar e evitar votar na legalização e descriminalização do aborto. Na segunda, para evitar tensões com os movimentos feministas que apoiavam pautas da PJ, e, por outro lado, também esquivando-se de embates com a Conferência Nacional dos Bispos do Brasil (CNBB), os delegados foram orientados à 
abstenção nesta proposta. Porém, apesar desta orientação das lideranças, alguns integrantes se posicionaram contra a abstenção tendo em vista o posicionamento da igreja. Com isso, muitos participantes votaram contra a proposta de descriminalização e legalização do aborto, rejeitando a ideia de que o poder de orientar a forma de votar parta sempre de lideranças, reforçando o caráter fluido das relações de poder.

Ainda nesta temática, na $3^{\text {a }}$ Conferência Nacional, a PJ produziu um subsídio no início do processo destacando quais as bandeiras a PJ defenderia. Este documento foi retomado no início da conferência. Porém, partindo de uma concepção de que a PJ prepara os jovens para autonomia e rejeitando a lógica do indicativo de voto por parte de lideranças, não foi feito indicativo de propostas a serem votadas. $\mathrm{Na}$ questão do aborto, ainda que não houvesse consenso, em alguns espaços de debate, vários integrantes da $\mathrm{PJ}$, com destaque para as mulheres, se colocaram favoráveis à descriminalização do aborto.

Encerro aqui este quinto capítulo, que corresponde à primeira parte de minha análise, em que busquei me centrar no relato e na descrição de algumas memórias de pesquisador participante das etapas nacionais, e organizador das conferências municipais. Isso me permitiu revisitar os relatórios finais das Conferências Municipais de Juventude, resgatando fatos que já estavam se perdendo entre tantas outras lembranças. Outras análises serão tecidas no capitulo a seguir a partir das entrevistas realizadas com participantes e organizadores das edições municipais aqui apresentadas. 


\section{6- TERRITÓRIOS INVESTIGADOS}

Como mencionado anteriormente, foram definidos os seguintes territórios de investigação os quais abordarei a seguir, juntamente com seus subtemas:
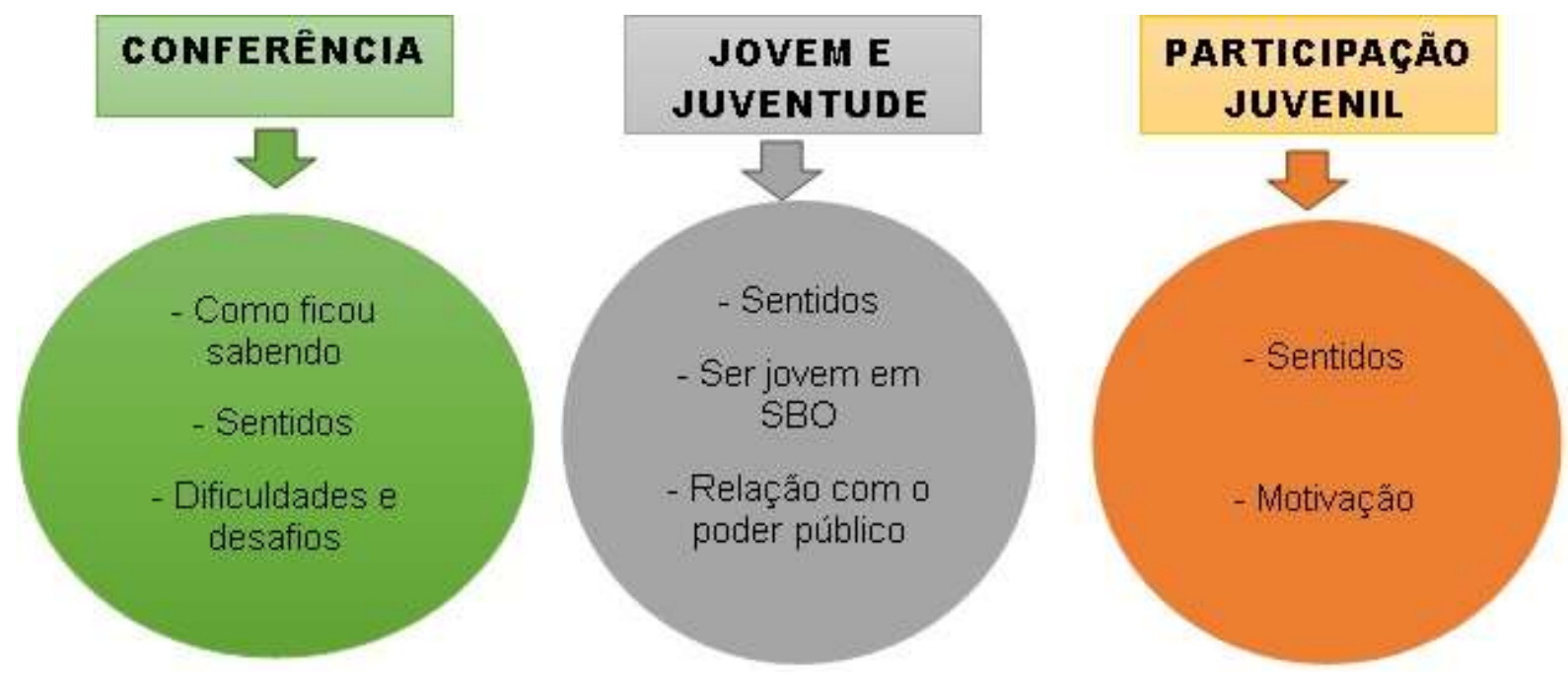

Figura 13 - Territórios Investigados

A seguir, procederei a análise de cada um dos territórios investigados a partir do referencial teórico escolhido para esta pesquisa.

\section{1- Juventude e Jovem}

6.1.1 - Juventude e o ser jovem: discursividades a partir de Santa Bárbara d'Oeste

Retomando as escolhas conceituais adotadas no Capítulo 2 e pensando a juventude como um território que é delimitado por contornos construídos discursivamente, volto aos contornos apresentados para problematizar as construções discursivas apresentadas pelos participantes das conferências de juventude em Santa Bárbara d'Oeste.

No espaço das conferências, a juventude e o jovem são territórios demarcados juridicamente no EJ como sendo os indivíduos que possuem idades compreendidas 
entre 15 e 29 anos. Ou seja, embora se busque reforçar que o jovem é um sujeito de direito, não é negado o discurso da faixa etária. Posto que, sobre o argumento da necessidade de uma definição para promover políticas públicas, se adotou no Brasil um conceito amparado e apoiado em proposições de organismos internacionais que privilegia as idades como dispositivos de demarcação de territórios.

Porém, ao explicar os lemas propostos em nível nacional para as conferências que reverberam em todas as suas etapas preparatórias, é possível observar outros contornos discursivos, como apresentado no Capítulo 5. Nas conferências, com a proposição do jovem como sujeito de direito e dentro da faixa etária, reafirmado por meio de aparatos jurídicos, ele é visualizado num discurso, do jovem como protagonista no desenvolvimento estratégico do Brasil. O jovem como militante é a identidade que domina o espaço das conferências.

De forma geral, o contorno da juventude enquanto problema costuma ser refutado e combatido por todos os participantes e isso perpassa todas as etapas preparatórias, desde a etapa municipal até a etapa nacional. Porém, como pesquisador militante e participante das etapas, noto que estes contornos discursivos reverberam de modos diferentes ao comparar etapa nacional e municipal.

Quando observo o contorno discursivo da faixa etária, na etapa municipal, ele não é tão presente e evidenciado, ao definir juventude. Esta observação surge nas narrativas, ao não explicitarem a definição de jovem e juventude como delimitada entre os 15 e 29 anos. Neste aspecto, alguns participantes que possuem idades superiores, ou ainda inferiores a esta faixa etária, participam sem grandes constrangimentos ou limitações.

Em especial a partir da $4^{a}$ Conferência Municipal de Juventude, a norma, tendo por base o estabelecido no regimento nacional, limitava a eleição de representantes para etapas subsequentes a 50\% compreendidos na faixa etária de 15 a 29 anos. Isto, porém, nunca causou grandes disputas considerando que o número de vagas previstas para etapa regional sempre contemplou de imediato todos os interessados e o número de participantes, com idade superior a 29 anos, nunca passou de 3 ou 4 pessoas.

Ao cartografar os sentidos da juventude e do ser jovem com os participantes das conferências de juventude em Santa Bárbara d'Oeste, ainda que os contornos discursivos estejam presentes e coexistam simultaneamente, identifiquei outros 
sentidos e construções deste discurso sobre o sujeito engendrado como jovem no espaço da conferência e das políticas públicas de juventude.

Para os participantes das conferências de juventude em Santa Bárbara d'Oeste, a juventude recebe uma configuração como apresentado por Salih ao analisar as teorias de Butler:

\begin{abstract}
Butler argumenta que a identidade de gênero é uma sequência de atos (uma ideia que assenta em teorias existencialistas), mas ela também argumenta que não existe um ator, um performer preexistente que pratica esses atos, que não existe nenhum fazedor por trás do feito. Ela esboça aqui uma distinção entre performance (que pressupõe a existência de um sujeito) e performatividade (que não o faz). Isso não significa que não há sujeito, mas que o sujeito não está exatamente onde esperaríamos encontrá-lo - isto é, "atrás" ou "antes" de seus feitos.

Isso parece apontar para a conclusão de que gênero não é algo que somos, é algo que fazemos, um ato, ou mais precisamente, uma sequência de atos, um verbo em vez de um substantivo, um "fazer" em vez de um "ser". (SALIH, 2012, p.65-66, grifos do autor)
\end{abstract}

Assumo este novo contorno discursivo sobre juventude ${ }^{76}$ me apropriando dos conceitos apresentados por Butler (2003), Salih (2012) e Silva (2000) para problematizar as teorias de gênero ao interpretar as idades enquanto dispositivos de produção de sujeitos. Acredito que, quando penso juventude, a partir das narrativas dos participantes das conferências de juventude em Santa Bárbara d'Oeste, trata-se de algo que não "somos", mas que "fazemos", num devir constituído por uma sequência de atos. Desta forma, não temos uma identidade etária, mas nos tornamos determinadas identidades etárias.

Os atos constituintes do sujeito jovem são apresentados a partir das ideias de identidade e diferença, como observo nos trechos abaixam que narram o que é juventude para os entrevistados:

Dandara: Um momento onde a gente sofre e vive coisas muito bacanas e intensas, tem uma necessidade muito grande de viver.

Caio: É um momento importante da vida.

Melissa: É viver intensamente e defender ideias que o conservadorismo rejeita.

Davi: É ter um estado de espírito que se renova a cada dia.

Lara: É você estar preparado para novas coisas, os mais novos geralmente aceitam as novidades melhores, então qualquer um que tenha juventude é capaz de aceitar novas coisas... Ela é... animada, muito animada, ela...nossa minha mãe é incrível, tem tantas coisas que a minha mãe é tão jovem... é... ela brinca, tipo, ela não fala assim, não, eu tô cansada, não vou brincar, tipo, ela brinca, ela procura saber mais sobre as coisas...

${ }^{76}$ Os conceitos de performance, performatividade são propostos a partir das obras de Butler(2003), Salih (2012) e Silva (2000), porém o contorno performativo como definidor de idades foi encontrado também nas obras de Martins e Rosa (2013), Cruvinel (2010), Pocahy (2012), Schlaucher (2012) e Andrade (2015). 
Tais reflexões me levam a pensar que, embora no espaço das conferências de Santa Bárbara, que também servem como dispositivos produtores de sujeitos, mas, especificamente neste caso, do sujeito jovem, que estas características apresentadas não estão fixadas em uma faixa etária.

Ainda que exista captura nas ideias apresentadas pelos participantes que são disparados por outros dispositivos, eles mesmos não vinculam estes atributos, pois julgam serem próprios da juventude, limitada na faixa dos 15 a 29 anos, como definido pelo EJ.

Mesmo que os adjetivos deste ato performativo se aproximem do proposto por Debert (2010) e Kehl (2004) que abordei no Capítulo 2, ao problematizar a juventude enquanto produto mercadológico, penso que a partir do espaço das conferências utilizamos um conceito capturado e fortemente subjetivado a partir da mídia e de outros dispositivos que nos agenciam, e o ressignificamos a partir da periferia e do encontro com o outro, a partir do emaranhado de subjetividades que se apresentam neste espaço. Acredito que as palavras de Takeuti (2012b, p.432) retratam bem este processo produzido no espaço das conferências municipais:

Inspirado em Spinoza, que aborda não o nível do sujeito-indivíduo, ou seja,
das identidades, mas sim a vida, a potência da vida. Toca-se aqui, o plano
das vivências concretas - a pragmática social - com incidência na
subjetividade do jovem que passa a lidar de maneira diferente com o princípio
da realidade. Isto é, o plano das experiências, as quais se encontram
conectadas com processos inventivos de experimentação coletiva, numa
ideia micropolítica e fora dos reais do trabalho ativo e produtivo ou às
margens da dinâmica da produção.

Em resumo, pegamos o território estriado da juventude e o transformamos em território liso, a partir de práticas de subjetivação nômade. Mais tarde, este território liso volta a se estriar a partir dos governamentos e de possíveis fixações de conceitos e territórios, e de novas capturas engendradas discursivamente.

Bem como outros dispositivos, para o espaço das conferências municipais esta "linguagem não se limita a proposições descritivas, mas é capaz de fazer coisas de fato acontecerem e se efetivarem" (SCHLAUCHER, 2012, p.4).

Schlaucher aponta como as performatividades se efetivam produzindo sujeitos:

A aplicação do conceito de performatividade em um sentido mais amplo nos mostra que ao dizer o que um determinado grupo é ou deixa de ser, nos inserimos em um sistema linguístico que serve para reforçar a identidade atribuída cultural e socialmente. Nesse sentido, até mesmo proposições descritivas, que a princípio apenas relatam o estado das coisas, podem 
exercer função performativa quando excessivamente repetidas, produzindo o fato por meio da repetição da enunciação. (SCHLAUCHER, p.4)

Trata-se da citacionalidade produzindo performatividades e sujeitos. Aqui penso que a repetição destas características à juventude atribuída, é responsável por produzir o sujeito jovem.

Assim, problematizo que, conforme as narrativas apresentadas, a juventude é assumida como um ato performático, quando os entrevistados a apresentam como um estado de espírito, dissociado da ideia da idade biológica, assumindo-a da mesma forma como propõe Groppo (2013, p.3):

\begin{abstract}
Atualmente, contudo, a palavra juventude tem outra conotação, passando a ser considerada algo como um estado de espírito, uma disposição pessoal, corporal, uma vitalidade desejada por todos. A aparência e o comportamento jovens passaram a ser partes de um ideal. A juventude se tornou então "juvenilidade": foi da fase de maturação ao estado de espírito, algo a que se escolhe ser.
\end{abstract}

Esta ideia performática de juvenilidade não é construída apenas pelos participantes que a descrevem em suas narrativas. As performatividades da juvenilidade são constituídas dentro do conceito de dobra proposto por Deleuze e Guattari, e utilizado por Takeuti (2012a, p.12, grifos do autor) para problematizar o processo de subjetivação da juventude:

Dobrar-desdobrar implica também o envolver-desenvolver, o involuir-evoluir.
Na dobra há necessariamente forças em inflexão e inclusão. O importante a
reter disso, por ora, é que 1) no mundo social, assim como no mundo físico e
dos viventes em geral, existem corpos com poder de afetação (uma força é
afetada por outras ou afeta outras); 2) na medida em que passamos de uma
visão dualista para a multiplicidade em afetação (multidão - e não massa -
com potencial de construir novas dobras), podemos conectar com o potencial
emergente do novo.

Penso que esta possibilidade, do dobrar e desdobrar presente nas narrativas, permite em um espaço estriado como o das conferências de juventude a desterritorialização do conceito de juventude, delimitado a partir dos contornos discursivos da juventude, enquanto uma etapa da vida compreendida entre 15 e 29 anos.

Ainda que existam capturas nesta forma de construir discursivamente o jovem e as juventudes, vejo que em um espaço onde o território já está dado, trata-se também de uma prática inventiva.

Esta construção discursiva do que é ser jovem no espaço das conferências de juventude traz devir ao não permitir que simples recortes etários, definidos por leis e 
por organismos internacionais, sirvam como limitadores ou definidores de idades e diferença no espaço das conferências municipais. Digo isto, pois, enquanto participante, em momento algum vi diferenciação ou interditos, devido à idade de quem participava ou pedia a palavra. Em resumo, acredito que o fato de ter de 15 a 29 anos não funciona como um limite para participação nas conferências municipais em Santa Bárbara d'Oeste.

Estas interdições surgem apenas no momento em que determinados participantes passam a monopolizar o uso da palavra, ou diria, quando alguns começam a exacerbar o protagonismo, silenciando outras vozes que desejam também propor e debater temáticas no espaço das conferências.

Porém, acho importante demarcar que, ao sair da etapa municipal para as fases subsequentes, esta característica começa a se perder e o contorno etário volta a territorializar a juventude, que também é territorializada por outros atributos, inclusive dentro de características da sua multiplicidade, que nos permite falar em juventudes ${ }^{77}$.

As dobras produzem a multiplicidade juvenil, e ao falar de multiplicidade também considero a juventude como um território amplo e heterogêneo que não pode ser totalizado (TAKEUTI, 2012a), mas constituída discursivamente em determinados contextos sociais, funcionando como dispositivo que atende propósitos políticos e sociais, sendo que a escolha por determinadas performatividades juvenis não é escolha totalmente livre. Quanto a isto:

Não há possibilidade de nossa escolha ser inteiramente "livre", e é bem
provável que a "escolha" de nossas roupas metafóricas se ajuste às
expectativas ou talvez às demandas de nossos amigos ou colegas de
trabalho, mesmo sem nos darmos conta de que estamos fazendo isso.
(SALIH, 2012, P.72-73, grifos do autor)

Desta forma, problematizo que a juventude é efeito e não causa. Como apresentam Butler (2003) e Salih (2012), não há um "eu" fora da linguagem, e as juvenilidades são produzidas pelos discursos.

Ainda que de forma provisória, faz sentido pensar a juventude, tendo como referencial as problematizações de Butler e Salih sobre as identidades de gênero. Nestas teorias, gênero é discorrido como estilo corporal.

Penso que as identidades etárias também recebem estes contornos nas narrativas apresentadas pelos entrevistados sobre o ser jovem e a juventude,

77 Aqui me refiro a grupos de manifestações culturais, ambientais, organizações de juventudes religiosas, partidos políticos ou organizações estudantis. 
elencando uma série de atos repetidos, responsáveis por constituir a juventude enquanto identidade, reforçando a juventude como uma construção discursiva, como apresentada no Capítulo 2. Isto é, percebo, pois:

Argumento para demonstrar como o corpo aparentemente "natural" não é mais do que "um efeito naturalizado" do discurso. Trata-se do corpo como significado e como significação, um corpo que só pode ser conhecido por meio da linguagem e do discurso - em outras palavras, um corpo que é construído linguística e discursivamente. (SALIH, 2012, p. 113, grifos do autor)

Porém penso também que estes discursos e o desejo em assumir a juventude enquanto uma performatividade associa-se ao exposto por Pocahy (2012, p.47):

Sabemos que a idade que levamos é a forma também de dar inteligibilidade ao que pode ser considerado como uma vida possível socialmente, desde engajamentos políticos institucionais e arranjos culturais. Desta maneira, estamos diante de um agenciamento discursivo que não faz outra coisa que tentar situar o sujeito de forma reconhecível e como um sujeito que possa ser citado - que produz experimentações de si desde/como atos performativos como sujeito possível ou pensável.

A escolha ou atribuição de determinadas performatividades etárias, neste caso, da juventude, está também relacionada ao querer fazer parte, ou participar de determinados grupos e espaços, bem como uma estratégia de fixar os sujeitos em determinados espaços, a partir da sua participação ou inserção. Assim, ser jovem no espaço da igreja faz com que o padre e a comunidade tenham determinadas expectativas sobre a atuação do jovem e os espaços onde ele cabe estar, inclusive nos espaços de coordenação, o que se reproduz em locais de participação política como o das conferências, quando optamos por assumir a performatividade juvenil.

Um exemplo que retomo é a questão da redução da maioridade penal que vem sendo debatida e apresentada desde a primeira conferência como proposta prioritária. No espaço das conferências, seja ele municipal, regional, estadual ou nacional, o que se espera do jovem é um pensamento e uma posição contrária a redução da maioridade penal. Defender o contrário sempre soa como heresia, levando também à desestabilização da sua condição enquanto jovem. Em outras palavras - Como pode um jovem ser a favor da redução da maioridade penal? Quase sempre, neste momento, o discurso da multiplicidade, ou do respeito a opiniões é deixado de lado, quando o assunto debatido é visto metaforicamente como cláusula pétrea. Nestes espaços, a identidade jovem, definida por quaisquer contornos discursivos, pressupõe existirem posições que são esperadas dela. 
Para os participantes das conferências de juventude em Santa Bárbara, assim como afirma Butler (2003) e apresenta Salih (2012, p. 67) sobre gênero, juventude não é "natural", "não há uma relação necessária entre o corpo de alguém" e a sua idade. Para eles, juventude é vista como um devir:

Dandara: Eu volto para essa questão da possibilidade de você construir alguma coisa, de você desconstruir, de você, ao mesmo tempo, falar que você não quer nada daquilo [...] Então, eu acho que ser jovem é aprender a lidar com essa frustração, porque é através dela que você consegue viver essa juventude atual... Então, as coisas, quando você é jovem, elas têm uma possibilidade de concretização muito grande, porque, agora, sou eu que decido, entendeu?

Thaís: Nossa, a melhor coisa do mundo. Jovem, pra mim, é o estado de espírito, não é a idade. É o que você sente. Jovem é ter sonho, ter objetivo, ou não, ou falar foda-se tudo, e eu quero fazer isso, vai e faz, sempre ter pensamentos de vai ter uma esperança, entendeu? Pra mim, jovem é o estado de espírito. É você fazer as coisas que você gosta, sem você se importar se alguém está olhando ou não. Pra mim, é isso. Eu quero ser sempre jovem, mesmo se eu estiver velha.

Hugo: Então eu acho que juventude eu acho que é isso, é um estado de espírito mesmo, você estar bem com você mesmo, de aproveitar o que a vida tem de melhor aí, para sair das teorias preexistentes aí.

Ainda que o contorno da juvenilidade reforçando a juventude enquanto um ato performativo apareça em todas as narrativas, ela possui limites e, ainda que negadas, são feitas associações à idade corporal. Um exemplo disso é que, embora uma pessoa de 60 anos se apresente enquanto jovem, e mesmo que algumas pessoas vislumbrem nela as características atribuídas à juvenilidade, não se pode negar que existe em determinados espaços uma negativa em reconhecer esta pessoa enquanto jovem. Este fato está delimitado por atos performáticos e corporais atribuídos discursivamente à velhice.

Considero, assim, que a juventude, ainda que vista como ato performativo, possui limites. Talvez, enquanto adulto, alguma pessoa ainda possa ser reconhecida enquanto jovem, porém com o passar dos anos e o surgimento de características físicas que remetem à velhice os contornos discursivos da naturalização e demarcação de idades a partir de atributos físicos voltam a aparecer. A juventude passa então a ser vista naquela pessoa apenas no sentido de admiração, por ela apresentar maior vitalidade se comparada à outra que na mesma faixa etária se compreende como jovem

Embora não tenha sido citado pelos organizadores durante as entrevistas, me recordo que os discursos sobre juventude apresentados pela SNJ e CONJUVE eram 
reforçados pelos organizadores. Em vários momentos, reforçávamos os discursos de juventude enquanto sujeito de direito, e que juventude designa quem possui de 15 a 29 anos, conforme os documentos institucionais.

Em meus diálogos com os participantes, busquei também cartografar e identificar possíveis diferenças conceituais para juventude e jovem. Porém, durante meus voos e pousos nestes territórios, a partir das narrativas, observei que, ainda de forma inconsciente, as duas palavras eram utilizadas de forma indissociável e muitas vezes como sinônimas.

Ao tentar aproximações na tentativa de sentir tessituras que diferenciassem os sentidos de juventude e jovem, observei que muitos tinham dificuldades em realizar tal diferenciação. No caso do termo juventude, os sentidos se aproximavam de características ou adjetivos relativos a ato performativo, enquanto que ao sentido de jovem se relacionavam ações que poderiam constituir o sujeito em jovem.

Desta forma, talvez seja possível pensar que a juventude é característica do sujeito jovem. Em outras palavras, tendo por base as linhas de subjetivação, ao adotar certos atos performativos, o sujeito torna-se jovem. Esses atos nas narrativas são por mim entendidos como linhas que subjetivam os corpos jovens. Assim, considero importante o problematizado por Peres (2013, p.54):

A adolescência/juventude pode ser vista como um período que cada vez mais
parece se expandir na transcontemporaneidade, começando cada vez mais
cedo e terminando cada vez mais tarde na vida das pessoas. Não se trata de
uma etapa de desenvolvimento com uma estrutura fechada, com
características universais, mas de territórios de passagens, de
experimentações que podem ou não contribuir para a adultez.

O problematizado por Peres na tentativa de desterritorializar a juventude desfazendo os contornos etários, e adotar ainda que temporariamente esta concepção de juventude, é sugerir que a juventude vista como idades não é verdadeira nem falsa. O importante é reconhecer que existem outras possibilidades de territorialização e de construção discursiva da juventude, além daquelas produzidas por aparatos discursivos, jurídicos e institucionais mesmo no espaço das conferências, capturadas, metodologicamente e em sua estrutura de funcionamento, a partir de deliberações e orientações da SNJ e do CONJUVE.

No caso das políticas públicas, esse território é definido pelo dispositivo idade através da SNJ e do CONJUVE, porém os sujeitos que ocupam e participam deste espaço podem atribuir à juventude outros sentidos, conforme expõe Peres (2013, p.54): 
Esses diversos marcadores/linhas evidenciam que não existe uma única ideia ou conceito a respeito de adolescência/juventude, pois a sua efetuação se dá através de relações de saberes, poderes e prazeres que negociam a expressão da adolescência que, embora não seja fixa, é autorizada para se expressar naquele espaço-tempo de sua existencialização.

No caso da juventude, quando se discutem políticas públicas, este espaçotempo é a faixa etária dos 15 aos 29 anos. Porém, ao falar sobre o que é juventude e o que é ser jovem, os entrevistados presentes nas conferências de Santa Bárbara d'Oeste reescrevem estas discursividades ao negar este espaço-tempo demarcador do território juventude, reconhecendo que "os processos de configuração das juventudes se mostram extremamente complexos e se conjugam como jogos de saberes, poderes e prazeres em constante mutação", conforme problematizado pelo referido autor (p. 62). Ele destaca ainda:

Juventude também pode ser produzida pelas vias das resistências, como expressão jovem diante da vida, de questionamentos sobre as ordens e regras estabelecidas que implicam potências, curiosidades e conectividades positivas com diferenças e estilos de vida. (PERES, p. 54)

Apesar deste indicativo de resistência, os entrevistados também destacam as tecnologias etárias que buscam localizar a juventude como um espaço-tempo de formação para a vida adulta.

Dandara: Porque é a geração do "nem nem", nem trabalha, nem estuda, você não está fazendo nada lá, então, nossa, causa um desconforto muito grande e é essa questão que eu falo que é uma imposição, também. Uma imposição muito além do que política, cultural, que é essa que o jovem, ele tem que se formar, ele tem que trabalhar e estudar, porque é super bonito um jovem que trabalha e estuda. "A minha filha?" Se falar que a sua filha só estuda, não tem a mesma meritocracia. "Mas a minha filha ela trabalha e estuda, ela trabalha o dia inteiro, ela chega em casa 11 horas da noite. Final de semana? Final de semana minha filha passa o dia inteiro em casa estudando". Então, assim, e outra coisa que eu acho, assim, que é o maior agravante ainda, que é o que está fazendo com que a gente se torne uma sociedade doente. A gente está sendo privado de se relacionar, porque essa cobrança de que a gente produza alguma coisa, que seja, que a gente construa um profissional de sucesso, que a gente construa uma carreira, ela é tão grande que ela está impedindo que a gente se relacione. Uma, porque a gente não tem dinheiro. Jovem que trabalha e estuda, raramente ele tem dinheiro para essas coisas e, outra, porque esse sistema está fazendo com que a gente acredite nisso.

No apresentado por Dandara, as tecnologias do eu, que aqui compreendo como tecnologias etárias, localizam a juventude como faixa de transição para a vida adulta, logo o sujeito da juventude, o jovem, deve ser preparado visando o problematizado por Peres (2013): 
Nesta configuração, encontramos a subjetivação de jovens dóceis úteis, submissos e coniventes com as biopolíticas regulatórias que incidem sobre seus corpos, desejos e prazeres, que por sua vez promovem a emergência de pessoas restritas aos imperativos da norma e da manutenção de modelos previamente dados pelas desigualdades sociais, raciais, sexuais e de gêneros e que, por isso, precisam entrar no circuito competitivo e desigual. (p.61)

Os modos pelos quais a sociedade heterossexista e falocêntrica, regida por sistemas binários e universalizantes, impõe determinados princípios e modos de relações autorizadas para a composição dos modos de ser jovens em tempos atuais; modos estes que reduzem as expressões da juventude ao modelo da jovem e do jovem branco, burguês, heterossexual, estudante e/ou trabalhador com projetos profissionais e desejos de constituir família e ter filhos [...] Privilégios e premiações [...] reproduzem os modelos dados e participam da manutenção do padrão normativo e normatizado. (p.64)

$\mathrm{Na}$ visão dos entrevistados, surge nas narrativas uma construção do jovem como problema, não apresentada nos relatos como opinião dos participantes, mas vista por eles como a forma como a sociedade enxerga o jovem:

Félix: Não é essa a situação... o jovem é meio que criticado sabe... o jovem... tudo é culpa do jovem... né... o estado não tem culpa... o jovem tem culpa porque ele... ah ele mata, ele rouba... tudo é em cima do jovem... né mas quando na verdade o estado que é incompetente né.

Em meu percurso, como participante, seja na etapa municipal, estadual, regional e mesmo nacional, reverberava sempre uma repulsa a esse tipo de discurso.

Negar a juventude enquanto problema, ou enquanto etapa de vida que é vista por muitos como futuro, e não como presente, para nós era tática de guerra, no sentido de inimigo a ser combatido.

A negação a estes contornos discursivos não se limitava ao espaço das conferências e se repetia em todos os espaços onde éramos chamados a assumir a nossa performatividade não apenas de jovem, mas talvez até de jovem militante. Assim, este discurso após a conferência se refletia na igreja, na escola, no grupo de amigos, em casa, em debates com os pais, e assim disseminávamos nossa tática de guerra na tentativa de enfrentar o discurso reverberado por alguns veículos de comunicação e que ressoa na sociedade.

E em muitos espaços, quando reencontrávamos jovens participantes das conferências, estivessem eles inseridos em espaços tradicionais de participação ou não, observávamos este mesmo discurso.

Desta forma, penso que a institucionalização dos espaços das conferências serviu também como tentativa de enfrentar as capturas apresentadas pela mídia televisiva, que representa no país uma das principais formadoras de opinião, tentando 
resistir e propagar novas discursividades sobre o jovem e a juventude. Aqui vejo na conferência sua potência, enquanto espaço de formação de jovens, ou não, resistindo aos rótulos muitas vezes atribuídos à performatividade juvenil.

Por isso também considero que assumir a juventude como ato performativo, diante do exposto pelos entrevistados, ainda que identifique capturas, pode ser visto como um devir, uma resistência ao buscar no espaço das políticas públicas negar também

Em concomitância com os processos de subjetivação normatizadores, que fabricam indivíduos em série e em escala febril encontrarmos outros modos de subjetivação que favorecem a emergência de sujeitos criativos, configurados por outras dimensões da vida que fluem por outras lógicas que, ao invés de tomar a pessoa como indivíduo, uma unidade acabada e totalizada, tomam-na como múltipla, diversa e descontínua. (PERES, 2013, p. 74)

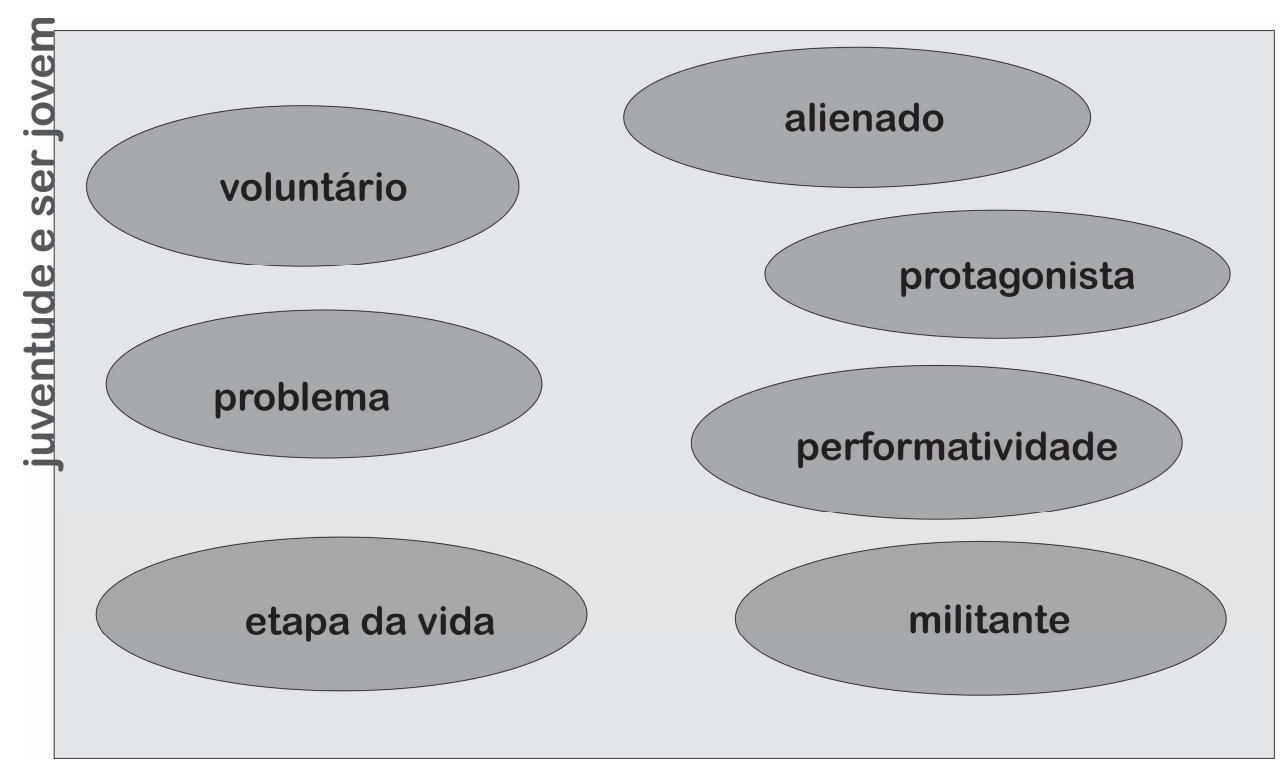

Figura 14 - Sentidos atribuídos ao ser jovem e juventude

A figura 14 apresenta os sentidos atribuídos ao ser jovem e a juventude, percebidos a partir das entrevistas com os participantes de quatro edições das conferências, ponto abordado neste sub-item. A seguir, abordarei os sentidos atribuídos ao ser jovem diante do espaço do município de Santa Bárbara d'Oeste, apresentando alguns tensionamentos presentes nas relações entre o jovem e o poder público. 


\subsection{2 - Ser jovem em Santa Bárbara: problematizações sobre o ser jovem no espaço da cidade}

O espaço das conferências se configura como um espaço marcado por relações de poder. As relações de poder podem ser observadas, por exemplo, desde a composição da comissão organizadora municipal, em suas reuniões e durante os debates para proposição e redação das propostas que comporão o documento final. Estão presentes também na escolha de delegados que vão representar o município em outras etapas, assim como nos jovens que vão ao espaço, porém se recusam a participar da programação instituída. Mas as relações de poder em um espaço que se propõe a ser de diálogo entre poder público e sociedade civil também estão nos tensionamentos produzidos a partir destas relações.

Quem se propõe a realizar uma conferência, uma vez que esta é convocada através de decreto municipal, em tese deveria estar disposto a ouvir, bem como receber as proposições e continuar o diálogo visando à transformação das proposições em políticas públicas.

Claro que isto não implicaria desconstituir o proposto por Fonseca (2006), já mencionado no Capítulo 3, relacionado aos espaços construídos para governados e governos. O caminho da escuta e do diálogo, ainda que não eliminasse as tensões entre sociedade civil e poder público, uma vez que as relações sociais sempre implicaram relações de poder e, simultaneamente, resistências, poderia motivar as pessoas que participam das conferências, como poderia também aproximar a sociedade civil do poder público, uma vez que em tese suas proposições estariam sendo consideradas pelo poder público.

Porém, como em nossa sociedade triunfa entre governados o sentimento de injustiça e indignação pelo olhar desatento por parte do poder público às demandas da sociedade civil, a sociedade segue se mobilizando "pela indignação diante do que fora feito de injusto com sua história" (DIAS, 2002, p.10).

No caso das conferências de juventude, e também para além delas, os entrevistados, de forma unânime, narram a desatenção do poder público com a juventude, o que acaba por reverberar na forma como estes jovens sentem-se aceitos e nas relações de pertencimento ao espaço de Santa Bárbara d'Oeste enquanto cidade, território de desejos e emoções desta juventude. 
Todos os entrevistados não identificam preocupação do poder público, seja executivo ou legislativo, com os jovens e com suas necessidades e demandas. Todos foram categóricos em dizer que não há preocupação com os jovens ou, se há, que é mínima e muitas vezes se resume a ocorrer no período eleitoral:

Melissa: É a preocupação assim... parece que a preocupação só tem a hora
que precisa em época de voto... época de éh... onde vai acontecer eleição...
aí a maioria dos líderes de juventude principalmente são procurados né... "ai
vamos lá... o que que vocês estão precisando... ai não sei o que... vamos
fazer um não sei o que lá... vamos... o que vocês querem?" né... quer dizer...
ele já perguntam o que querem porque nem eles sabem do que está
precisando.... né...(grifos meus)

Davi: Então eu classifico que o interesse do legislativo e do executivo é mínimo... mínimo mínimo mínimo... eles mantêm o protocolo... vamos recebê-los... vamos conversar porque eles vão dar problema... eu entendo dessa forma... porque quando eles não falam a gente vai para as mídias sociais... para as redes sociais... (grifos meus)

Lara: Eu não vejo muita preocupação, porque, é... o jovem ele, ele não é muito reconhecido, eu acho que ele devia ser bem mais reconhecido, porque, se ele fosse, poderia ser pessoas que no futuro, fariam um trabalho melhor sendo político ou não, um trabalho melhor pra sociedade mesmo. O jovem, eu acho que ele não é muito reconhecido em Santa Bárbara, ele não tem alguns... acho que não privilégios, questão de eventos também e ele não tem muito reconhecimento público. Eu acho que isso tanto parte do poder público que falta incentivar o jovem, quanto do jovem também, que não corre atrás disso. (grifos meus)

Félix: Porque a gente é considerado número né... esses dias mesmo eu fui no hospital... olha eu fiquei assim... estarrecido sabe... eu fui pedir para um... para um enfermeiro chamar a doutora sabe... ai ele falou "ah tem mais uma ficha aqui esperando"... ou seja... eu sou mais um no meio de tantos né... eu não sou simplesmente eu... eu sou simplesmente um numero né... então acho que deveria o estado individualizar as pessoas... isso que está faltando... (grifos meus)

Estas narrativas são produzidas tanto por organizadores, quanto por participantes das conferências e o sentimento apresentado durante as falas é carregado ao mesmo tempo de decepção, angústia e inconformismo. Quando penso o espaço das conferências, com exceção da $3^{a}$ Conferência Municipal na qual o prefeito não se fez presente e o debate foi dominado por membros do CoMJuv e vereadores de oposição, ambos descontentes com a administração municipal, este sentimento não se evidenciou nos grupos de trabalho e debate.

Porém não posso deixar de registrar também que este sentimento apresentado durante as entrevistas me angustiou no momento de pensar a $2^{a}$ Conferência, considerando que fui organizador e participei da $1^{\text {a }}$ Conferência. O sentimento era 0 de que "como posso pensar a $2^{\mathrm{a}}$ se as demandas da $1^{\mathrm{a}}$ não foram atendidas?" E esse 
sentimento muitas vezes se repetiu nas etapas subsequentes, pois, ainda que algumas propostas apresentadas no campo dos marcos legais tenham sido atendidas, a sensação de que estávamos fazendo uma conferência municipal, ou até nacional, para reafirmar o dito na edição anterior sempre se repetiu.

Mas acho interessante reforçar que, mesmo que isso causasse desconforto em mim e em outros companheiros de luta e organização das conferências, não sentíamos diminuído nosso desejo de estar, organizar e ver outros jovens participando, e tampouco víamos diminuída a nossa responsabilidade. Talvez a mola propulsora deste sentimento fosse a sensação e a rebeldia de que o que fizemos um dia sairia do papel e, no futuro, ao olharmos para trás, conseguiríamos enxergar a nossa responsabilidade dentro daquela construção que partiu do campo do desejo e do sonho. Isto servia também como estímulo para atuação fora do espaço das conferências, pois que muitas vezes nossa atuação e participação em outros espaços era orientada no sentido transformar em realidade as propostas apresentadas.

Retornando as narrativas da fala de Melissa, gostaria de problematizar dois pontos: "parece que a preocupação só tem a hora que precisa em época de voto" e “... ele já perguntam o que querem porque nem eles sabem do que está precisando". Estes pontos, resgatados da narrativa, mostram o interesse político eleitoral do poder público, e isto vale tanto para a Câmara dos Vereadores, quanto para a Prefeitura. Sinto que esta sensação é produzida em virtude do distanciamento entre os governados e os governos, sendo muitas vezes esta relação restrita ao espaço eleitoral. Quanto ao segundo ponto destacado, em tese, após a realização de quatro conferências, vereadores e prefeitos teriam um ponto de partida referente às necessidades da população. Isto evidencia a possibilidade de indagar por que os relatórios finais não são pontos de estudos ou atenção do poder público, o que acaba por desacreditar o rótulo de "espaço de diálogo entre poder público e sociedade civil" atribuído às conferências, e costumeiramente propagado tanto pelo poder público quanto pelas comissões organizadoras na hora de divulgar ou de abrir as conferências.

Diante do problematizado a partir da fala de Melissa, tenho percebido que nas quatro edições sempre tivemos vereadores que acompanharam o processo de construção das conferências de juventude, bem como sua realização. Com isso, se, para os organizadores, é difícil perceber a atenção do poder público, o que dizer dos 
participantes, considerando que os organizadores tinham uma oportunidade extra de diálogo nos momentos de organização e preparação da conferência.

Outro elemento importante para ser problematizado é que a fala de Melissa reverbera também no sentido apresentado pelos entrevistados Félix, Davi e Lara. Ao dizerem que a preocupação do poder público é mínima ou inexistente, eles não estão se referindo apenas à preocupação do poder público com o jovem participante da conferência. Também estão replicando um sentimento de como o município, a partir do poder público, capta, recebe os desejos e o "ser jovem" em seu espaço. Daí parte o sentimento de que "os jovens são vistos apenas como um número" ou "na hora do voto". Estas imagens explicitam um sentimento de não existência de diálogo produzindo questionamentos e tensionamentos que podem levar os jovens a não retornarem aos espaços participativos como os da conferência.

Sobre este sentimento, mesmo que a participação do vereador não ocorra em período eleitoral, é visto como interesse eleitoral, pois, para os entrevistados, quando são procurados para encaminhar as propostas da conferência, não percebem acolhimento dos vereadores. O mesmo é pensado a partir da análise da trajetória dos vereadores, que não possuem proposituras tendo por objetivo específico os desafios enfrentados pela juventude.

Problematizo também que a reclamação por falta de olhar do poder público é na verdade resultado da falta de políticas públicas voltadas para a juventude. Na visão dos entrevistados, o poder público é como o pai que às vezes se faz presente, porém não fornece subsídios aos filhos em suas necessidades e desafios. Desta forma, o poder público, na figura dos prefeitos e vereadores, desperta uma série de expectativas, que não se concretizam.

Outro elemento que problematizo e que amplia os sentidos apresentados nas narrativas anteriores, é que este olhar e sentimento de rejeição, para alguns participantes não estaria restrito ao poder público. Para Théo, isso transparece na visão que a sociedade barbarense tem do jovem:

Théo: As dificuldades são que... ah, para as pessoas a gente é... a gente só liga para diversão, só liga para sair, para zoar, para bagunçar, a gente não se preocupa com nada. E acho que é isso, a própria polícia mesmo, vê a gente como... sabe, pessoas que só sabem fazer coisa errada, assim, usar drogas, essas coisas assim, entendeu? A população... não é a população, algumas pessoas pensam que a gente não quer nada com nada, sabe? Que a gente só quer zoar e não está nem aí com o futuro da gente, o futuro da cidade, acho que é isso. (grifos meus) 
A fala de Théo reverbera uma visão produzida pelos dispositivos de produção de subjetividades que não está restrito ao espaço de Santa Bárbara d'Oeste, e que também não é um olhar de toda a população, mas relacionado ao contorno discursivo da juventude enquanto problema, rebelde e descompromissada, por rejeitar muitas vezes a fixação identitária produzida pelos dispositivos.

Acredito que a desatenção do poder público se estende a outros segmentos populacionais, como os idosos, as crianças ou os adultos. Porém as construções discursivas apresentadas por Théo e atribuídas a uma parte da sociedade barbarense refletem uma visão ou uma discursividade acerca da juventude comum na mídia.

Este sentimento de indignação presente nas narrativas acaba por servir de potência aos jovens participantes das conferências municipais, considerando o afirmado por Dias (2002, p.10) de que "o empobrecimento causa indignação e, ao mesmo tempo, mobiliza para a busca de modos de se viver juntos que sejam mais satisfatórios para todos". Muitos jovens, assim como eu e meu grupo de amigos que um dia sonharam realizar as conferências de juventude em Santa Bárbara d'Oeste, fomos movidos por este desejo e sensação de potência de que, como diria o poeta Beto Guedes, um mais um é sempre mais que dois. Salienta o autor referido:

Um outro campo de compreensão da política se refere ao movimento que se
passa nos subterrâneos da história, nos intervalos de nós mesmos, nas
entrelinhas do nosso dizer. Este movimento que escapa ao nosso controle
denuncia que nas nossas histórias acontecem mais coisas do que aquelas
imediatamente percebidas por nós. Trata-se da micropolítica, que em última
instância está diretamente vinculada ao modo como cada um se ajeita com a
própria finitude e se permite afetar e ser afetado pelo outro e pelo mundo.
Este campo das relações de poder nos remete ao universo das sensações,
ao movimento do desejo, às possibilidades que cada um tem de afetar e de
ser afetado. (DIAS, p.18)

Uma vez cartografados os sentimentos que reverberam na relação entre poder público e sociedade civil, busquei também, dentro deste olhar de como os jovens se percebem dentro do espaço da cidade, quais as situações e o que esperam os participantes do poder público. Neste sentido, observei que as reclamações são mais evidentes no que tange aos espaços voltados para o lazer, cultura e tempo livre, porém aparecem vários relatos de repressão policial e o preconceito que repercute no modo como a sociedade barbarense vê o jovem.

Dandara: O lazer é um problema muito grande que a gente tem aqui, porque é nesses momentos que você consegue ter algumas suavidades, que você consegue viver algumas coisas e construir, porque é um momento que você não tem uma obrigação, você faz porque você quer e Santa Bárbara tem essa 
dificuldade muito grande... Se eu quero sair com os amigos, eu tenho que ir em uma pastelaria, mas não necessariamente eu tenho dinheiro para ir na pastelaria. Ficar em praça não pode, porque a polícia não gosta que faz aglomeramento. Então, eu acho que, assim, a maior dificuldade aqui, que a gente tem, são nessas possibilidades de lazer, de a gente ter alguma coisa, ter o direito de falar que a gente [...] Porque o lazer, você não produz nada. Quando você está em uma praça, tranquilo, que seja tomando uma cerveja, fumando um cigarro, você não está produzindo. Então, para o poder público não é interessante. Você tem que produzir alguma coisa ou, se você não vai produzir, você paga por isso. (grifos meus)

Nas narrativas de Dandara, ao destacar a ausência de espaços públicos de lazer, novamente aparece o sentimento de negação à juventude nos espaços públicos e na promoção de políticas públicas. Para além disso, Dandara destaca sua percepção de que os espaços de lazer não seriam criados, pela visão de que o ócio não produz nada; desta forma, não despertariam o interesse e a atenção do poder público, uma vez que, nas sociedades capitalísticas, os sujeitos são produzidos para produzir, dentro da lógica da economia de mercado. Nesta escala de valoração apresentada por Dandara, que apareceu em outros momentos das narrativas, em uma equivalência de prioridade, a construção de escolas técnicas e dispositivos que transformam o jovem em um adulto produtivo, mentalidade disseminada pela sociedade burguesa, seria priorizada em uma sociedade que muitas vezes nega o valor e a importância do lazer e do tempo livre. Isto considerando que este tempo ocioso poderia possibilitar no jovem o surgimento de condutas anormais que causariam problemas ao corpo social.

Esta lógica movimenta também os casos de repressão policial apontados, em especial, em momentos quando o jovem busca o entretenimento, a diversão. Os jovens relatam também que, além de não haver espaços para esta demanda juvenil, os criados e oportunizados pelos jovens geram muitas reclamações, e incômodo por parte da população não jovem.

Thaís: Sim, preocupa, se preocupa em deixar ele longe da população, o que eu vi quando eu estava lá no conselho, que é muito difícil conseguir qualquer coisa com o jovem. A gente é até que meio ridicularizado, os skatistas, as coisas que estavam planejadas pra fazer para eles e eles não deram importância nenhuma. Então, se preocupa em deixar o jovem longe de problema, tipo, "vocês não podem causar problemas, então, não vai ter nada, pra vocês não saírem de casa e não causarem problema aqui. Vai causar problemas lá em Americana", entendeu? Tipo isso, "vai causar problema lá no posto da Avenida Brasil, não vem no posto aqui, que não vai poder", entendeu? É assim. Repressão! É, tipo, eles, uma hora, até liberaram fazer festa lá na frente do Fórum, mas o que tinha de polícia lá, enquadrando o pessoal e sendo desagradável, sem necessidade. Para que, então, pra que que eu vou lá fazer festa? Não vou poder fazer nada?! É ridículo, nossa, não tem sentido, não libera então, né? Se é pra ser desse jeito. 
Na fala de Thaís, além da dificuldade para transformar as propostas do CoMJuv em políticas públicas, que levou ao desestímulo em estar nestes espaços, há ainda a constatação de que a ausência de espaços para a prática de lazer, que leva os jovens a outros municípios, seria uma tática para que os jovens, vistos como produtores de problemas, os produzissem em outra municipalidade.

Percebo que o olhar de Thaís e de Dandara, ao enfocarem o lazer e o tempo livre, apresentam perspectivas diferentes, considerando que no olhar de Dandara transparece a necessidade de espaços públicos para o lazer destinados ao jovem. Já o olhar de Thaís traz uma perspectiva de falta de espaços privados, como boates/casas noturnas, para a prática do lazer nos finais de semana, como será mencionado em sua fala a seguir.

As casas noturnas existentes na cidade sempre foram poucas, e várias enfrentaram problemas com a justiça ou com o Conselho Tutelar, visto que, na visão destas autoridades, não propiciavam condições seguras aos jovens e adolescentes frequentadores. Assim, muitas acabam por ficar fechadas por muito tempo.

Esta ausência de espaços públicos para o lazer e o tempo livre acaba por despertar algumas comparações com a cidade vizinha de Americana.

Thaís: A cidade de Santa Bárbara é uma cidade muito atrasada, muito atrasada. Qualquer lugar que você for trabalhar, lá, é atrasado. Em relação à Americana, né, que está do lado. Não tem lugares para jovens ir, é tudo censurado, a polícia pega no pé, é horrível... Vou fazer uma comparação com Americana. Americana tem aquela feira de empregos, que vai ter agora, não sei se é a primeira edição, mas vai ter. Um monte de jovens vão. Não tem isso em Santa Bárbara, nunca, não tem lugares para sair em Santa Bárbara. Aqui tem, mas eu não vou, mas tem. Tem a Diamond, abriu o espaço Boulevard. Tem várias festas em Americana, no espaço Americana, no Americana Hall, tem festa do peão. E em Santa Bárbara? Não tem, não tem nem mais a feira da usina, que era o mais legalzinho que tinha para ir e não tem mais. Então, tudo tem que vir pra Americana. Tudo tem que ir pra Campinas, é perigoso, você sai dirigindo à noite, é difícil, tem que ter carro, porque não tem como você sair de Santa Bárbara. (grifos meus)

Amanda: Eu leciono em Santa Bárbara... na época de Festa do Peão de Americana... é uma semana morta dentro da escola... tanto que não é marcado prova... não é marcado trabalho para a semana de Festa do Peão de Americana... na semana de Festa do Peão de Santa Bárbara é marcado prova... é marcado trabalho... é marcado tudo (sorriu)... não existe nenhuma conversa ou diálogo dentro da sala dos professores a respeito de Festa do Peão de Santa Bárbara... mas existe para a Festa do Peão de Americana... então a dificuldade de ser jovem em Santa Bárbara é que Santa Bárbara é uma cidade anônima... então o jovem só tem perspectiva a partir do momento que ele tem referên/alguma referência...em Americana [...]aonde você estuda? estudo em Americana... aonde você trabalha? eu trabalho em Americana... então aí começa a ter referência...(grifos meus) 
Penso que hoje, no que tange a espaços privados de lazer, em especial bares e restaurantes, Santa Bárbara oferece possibilidades. O que ocorre atualmente, diferente do exposto por Amanda e Thaís, é que o deslocar-se para Americana e para outras cidades da região também está associado ao desejo do jovem de deixar a cidade onde vive em busca de outros espaços e de outros laços. No que tange às festas do peão, há um sentimento de glamour devido ao tamanho da festa do peão de Americana, o seu reconhecimento no cenário nacional, bem como as atrações que são convidadas para as apresentações. Trata-se sempre de cantores de renome, reconhecidos nacionalmente, enquanto as atrações convidadas para a festa do peão em Santa Bárbara, devido a suas proporções, são sempre cantores que já não estão mais em destaque no cenário da música brasileira.

Outro apontamento das narrativas é a ausência de espaços para participação, nos quais o jovem possa debater, falar e ser ouvido. O Conselho Municipal de Juventude (CoMJuv), apesar de existir há quatro, anos não tem visibilidade e ainda é pouco reconhecido como um espaço do/para o jovem.

\begin{tabular}{l} 
Hugo: O adolescente não vê aquele espaço como sendo um espaço de \\
transitar, de realmente buscar a saúde. Então eu acho que a juventude \\
também é um pouco isso, como que, onde que ela se vê, em quais espaços \\
ela se vê, e os espaços que ela poderia, que são oferecidos para ela, muitas \\
vezes não chega nessa divulgação de que eu "Ah não, ali é um espaço que \\
\hline eu posso estar", por exemplo, um Conselho Municipal de Juventude, embora \\
\hline tenha uma representação dos conselheiros, mas é um espaço aberto e como \\
\hline que eu chego até isso ou onde que está hoje no município o órgão de \\
juventude, quais são os movimentos existentes? Então, sempre acaba \\
girando em torno de um evento, então tem um determinado evento, aí se faz, \\
todo mundo sabe daquilo ali, mas depois volta no que a gente estava falando, \\
o quanto que a própria juventude, aí automaticamente a gente se inclui nisso \\
por conta do dia a dia, mas o quanto que você acompanha dos processos, \\
deveria ser o principal passo, mais do que simplesmente ir lá participar, talvez \\
essa é a intenção, o entendimento que eu tenho de participação.
\end{tabular}

Félix: Onde o jovem pode expor suas ideias... né... onde o jovem pode falar aquilo que ele pensa realmente... sabe sem ser manobrado pela massa né... ou mesmo pela mídia sabe... o jovem pode sim criticar... quem disse que não né? Então assim mais espaços... para debates eu acho... que deveria ser legal... espaços para debates mesmo...

Ainda que tenhamos alcançado algumas conquistas, como apresentado no campo dos marcos legais, com a criação do CoMJuv, da Coordenadoria de Juventude, do Fundo Municipal de Juventude, e a instituição bianual das conferências, a reflexão que faço, como pesquisador militante, é que tais conquistas não são conhecidas pela juventude. 
Penso que caso a pesquisa feita pela SNJ sobre a participação em conselhos e conferências fosse reproduzida em Santa Bárbara - vale lembrar que um dos pedidos do CoMJuv foi um mapeamento sobre a juventude barbarense para cartografar quem são os jovens barbarenses e o que querem -, o resultado se repetiria: poucos jovens responderiam que conhecem estes espaços e estes marcos legais, reforçando que o que ocorre em escala macro (ao pensar o espaço nacional) também ocorre na escala micro (ao pensar o espaço do município). De modo geral, estes espaços ainda estão restritos a alcançar apenas um determinado perfil de jovem: no caso nacional, como dito anteriormente, apenas o jovem militante e que esteja inserido em espaços tradicionais de participação; e, em escala municipal, o espaço se abre também para amigos de organizadores e para jovens interessados na temática política, e que em seus espaços participativos tomam conhecimento da conferência e do conselho.

Em meus diálogos com os participantes e organizadores das conferências, foi mencionada também a relação entre os jovens e o shopping como um espaço particular, não acolhedor ao jovem. Esta visão quanto ao shopping está atrelada aos "rolezinhos", forma de manifestação juvenil, visibilizada após 2013, que se dá sob a forma de encontros de jovens em shoppings, marcados pelas redes sociais. Esse tipo de manifestação ganhou notoriedade, em virtude da ação policial em "rolezinhos" que geraram aglomerações e ações judiciais dos shoppings visando coibir tais concentrações de jovens. O mesmo aconteceu em Santa Bárbara, porém com um diferencial: nunca foram observadas, no auge dos "rolezinhos", tais aglomerações dentro do shopping.

Os encontros, articulados via redes sociais, se traduziram em concentrações no canteiro lateral da avenida Santa Bárbara, defronte ao estabelecimento comercial. Antes de ser apelidadas de "rolezinho", as concentrações juvenis ocorriam no espaço interno do shopping, em especial às sextas e sábados, porém logo foi coibida, com correntes cercando o local e impedindo a concentração dos jovens nos espaços onde eles costumavam ficar.

Dandara: Então, eu só posso vir ao shopping em uma sexta-feira se eu estiver consumindo, até porque, agora, não pode mais fazer rolezinho, porque não pode mais ficar transitando. Então, eu não posso mais ir no shopping só para transitar, para ver gente, eu tenho que consumir alguma coisa. 
Esta prática realizada pelo estabelecimento comercial também já foi vista em outros espaços públicos. A avenida Monte Castelo, onde os jovens costumavam se concentrar nos finais de semana, estacionando carros e ouvindo música, foi bloqueada com placas de proibido estacionar, impedindo a concentração neste espaço. Na praça da Migração, onde o espaço era utilizado pelos jovens para concentração, após reclamações de moradores, os mesmos foram coibidos, através de ação policial para dispersar e evitar novas concentrações.

Elis: Eu tô ficando muito pessoal, tipo produtora. Eu vejo que não tem muito o que se fazer na verdade, você tem algumas pequenas oficinas que são ótimas, que assim a juventude se ocupa, tipo aqui, na própria Léo Sallum, tem aqui no centro de Santa Bárbara também, a própria escola da família, mas ainda não sei o que acontece q a galera não se interessa muito não. Tem atividade, é gratuita, mas é algumas coisas que ainda fica assim tipo, ah final de semana ou ah não sei o que, ah tenho coisa melhor pra fazer, mas que coisa melhor tem pra fazer? Você vai ver, é assistir TV em casa, então sei lá, talvez meios mais atrativos pra que a juventude se movimente ali, porque oficina tem, coisas tem, mas eu não sei o que acontece que não chama atenção ... talvez alguma coisa mais atrativa, mas... vai saber o que é mais atrativo pra esses vários pontos. E porque são vários pontos, né, você pega, igual na própria conferência municipal, teve um menino falando do rolezinho, pra ele é atrativo ir pra frente de um shopping e ficar lá.. pra ele é atrativo. $E$ agora, talvez, como o poder púbico possa pegar o que saiba que é atrativo pra ele e tornar isso... não legal, porque querendo ou não ele não tá lá ilegalmente, mas ser algo mais supervisionado, vamos dizer assim, e coisas do tipo, porque tem show de bandinha aí que lota, isso é atrativo pra juventude, mas porque que quando faz de graça, a própria prefeitura faz não lota tanto? Então é alguns pontos que a gente, não dá pra falar na verdade... são pontos que eu ressalto, mas eu ainda não sei qual a solução. Também. Quando eu era mais nova, eu participava muito de escola da família, lá no próprio Léo Sallum, eu tava envolvida nessas atividades de final de semana e tudo mais, mas eu era bem mais nova, não tinha todo esse interesse de militância, mas ainda participava de algumas coisas que era oferecido né e aí você vai crescendo e você não quer mais ficar indo na escola da família, você não quer mais fazer esse tipo de coisa e aí, o q a gente fazia, a gente ia ali pra praça do Tom Leite, em 2009, juntava todo mundo, era violão e bora lá, bora lá, e sempre colava o pessoal que ia pra beber, que ia pra fumar, enfim, e sempre tinha esses problemas, mas aí o pessoal se conheceu ali, aí tinha a galera que queria ir pra zuar, pra dar perca mesmo, mas tinha galera que só queria ali, começou a formar muita banda, começou a formar muito grupo, começou a sair vários coletivos que começou aqui na própria praça Tom Leite e vinha muita gente de Americana pra cá, então como a gente se conhecia todo mundo aqui, era tipo sexta, sábado e domingo, todo mundo se encontrava ali e foi todo mundo crescendo, já não tava mais nessa de só sair pra beber e começou a querer fazer coisas de verdade, e aí começou formar alguns coletivos em Americana e aí algumas bandas começou a se reunir, tem um projeto que chama Acusticando, tanto é do Ralf, mora aqui na Cidade Nova, mas ele faz o "Acusticando" em Americana, então eu já conhecida ele, eu comecei a ir pra lá e aí é mais bandas que vem e aí forma um festivalzinho aqui e outro sarau ali e vai se juntando e acabou que a gente já teve uma área ali em Americana, já fixa assim que a gente tinha essa certeza, porque eu vejo também, qual foi a problemática daqui, porque a gente se reunia ali sempre um jovem era expulso, pra levar tapa na cara era assim. 
Esta narrativa de Elis traz vários elementos para problematização. Acredito que o primeiro é o que contraria a falta de políticas públicas de lazer e tempo livre. Na fala de Elis existe a ofertada de atividades culturais, porém estas propostas acabam por não ir ao encontro dos desejos e espaços pensados para os jovens. Para mim isso reforça a necessidade do poder público conhecer as proposições das conferências, pois, ainda que não representem uma totalidade, elas trazem aspectos a serem considerados na implementação de políticas públicas de juventude.

Isto é latente quando mencionado que algumas atividades não atingem os interesses dos jovens. O esperado pelos jovens, ter espaços para "ficar de bobeira", não vem encontrando aceitação, e tampouco espaços em Santa Bárbara d'Oeste. Tais apontamentos salientam como é tênue e conflituosa a relação entre jovem e poder público nesta cidade.

Porém a narrativa de Elis mostra a potência e o ato criativo produzido a partir do encontro em Santa Bárbara d'Oeste. Talvez resolver esta demanda no que tange à cultura possa ser mais simples e factível e sem necessidade de altos investimentos. O narrado por Elis ao descrever os encontros na Praça do Parque Tom Leite se assemelha ao apresentado por Dias (2002, p.18):

Nas experiências de poder local em âmbito municipal podemos ousar mais. Podemos desencadear movimento de criação e organizar aparatos de sustentação para eles. Se conseguirmos isto abriremos um fascinante campo de sustentação para eles. Se conseguirmos isto, abriremos um fascinante campo de re-invenção da democracia.

Talvez estejam faltando ao poder público, no trato com a juventude, a ousadia e a teimosia que têm possibilitado aos jovens produzir, a partir da inventividade e da criatividade, mesmo diante de adversidades e em situações de recusa dos espaços públicos a sua subjetividade. Acredito que a oferta de espaços que possibilitem encontros dos jovens seja alternativa na tentativa de reduzir tensões existentes entre o poder público e a juventude.

Neste subcapítulo busquei retratar as percepções e os sentidos atribuídos ao ser jovem a partir das narrativas produzidas durante as entrevistas dialogando com o referencial teórico escolhido para esta pesquisa. Outro ponto abordado, diz a respeito sobre a percepção dos entrevistados sobre o ser jovem no município de Santa Bárbara d'Oeste. A seguir, abordarei os sentidos e os significados atribuídos a participação juvenil, bem como as motivações que levaram os entrevistados a participar das conferências de juventude no município. 


\title{
6.2 - Participação juvenil
}

\subsection{1 - Sentidos da participação juvenil a partir das conferências}

As conferências se configuram como grandes palcos ou arenas na produção de discursos. O conceito de arena política é apresentado por Goulart (2011, p.12) que destaca também a sua importância como processo de subjetivação:

\begin{abstract}
um campo agonístico no qual a organização social não se dá por via de um mero consenso, e sim pelo conflito produtivo de forças com estratégias distintas, contraditórias e, por vezes, convergentes. É nessa arena pública que estão colocadas não somente as políticas públicas para a juventude, mas os diversos discursos que dizem algo sobre os jovens e, ao assim fazê-lo, elaboram práticas sociais e modos de se vivenciar a experiência juvenil.
\end{abstract}

Vejo esta arena como responsável por produzir discursos não apenas sobre o ser jovem e a juventude, mas também sobre o que é a participação juvenil, inclusive levando a sua institucionalização como apresentado em Guizardi (2014, p.27):

Percebe-se, assim, que o campo da constituição dos direitos se abre como uma arena pública em que potencialmente diversos conflitos podem vir a se colocar, mesmo quando a sua intensidade tenha sido esvaziada pelos mecanismos institucionais das soluções modernas de inserção e participação política.

Ao abordar os modelos de participação juvenil, Groppo e Zamarian (2009) trazem elementos que visualizo como pertinentes para problematizar os sentidos da participação juvenil a partir do espaço das conferências. Os autores apresentam três modelos que são utilizados e servem de prisma para compreender as construções discursivas acerca da participação juvenil. São eles o militante, o alienado e o voluntário.

Estes modelos aparecem de forma intrínseca nas narrativas produzidas sobre a participação juvenil nas conferências de juventude em Santa Bárbara d'Oeste.

O jovem militante que, segundo Groppo e Zamarian (2009, p.4), teria passado por transições do século XIX e XX, é forjado como "em geral universitário e vindo das classes médias das grandes urbes mundo afora - rebelde, revolucionário, generoso, idealista, doador de seu tempo, energia e, às vezes, até de sua própria vida, para a transformação profunda da sociedade". Modelo cujo ápice foi o período da ditadura militar no país, quando os jovens tomavam as ruas para protestar contra o regime 
militar, este modelo é utilizado como referência na atualidade para classificar e avaliar a participação juvenil. Vejo indícios dele na narrativa produzida por Miguel e Elis.

Miguel: Participação juvenil... olha, eu acho que é o jovem tentar interagir mais com vários assuntos, não assuntos ligados só ao que eu gosto. Por exemplo, eu estou hoje na militância, eu vou ficar só com a militância LGBT, não é? Não, é geralmente pensar no próximo, é pensar em outros assuntos. E eu acho que a política é um meio que pode unir tudo isso. E tentar pensar em política e participação do jovem nessa política é mostrar que as ideias de novas pessoas, de novos conceitos, assim, que venham a existir, possam chegar lá e mudar alguma coisa, não ficar na mesmice na qual a gente já está. (grifos meus)

Elis: Eu resumo militância como sendo qualquer participação ativa sobre qualquer assunto, tem a militância do movimento feminista, movimento negro, movimento LGBT, militância de partidos, tem vários tipos de militância, eu acho que é se movimentar e querer fazer alguma coisa e informar pra quem não sabe, se movimentar mesmo, de todas as formas, seja criando espaços de discussão pra quem já tá dentro do assunto, ou seja numa mesa de bar falando um pouco do feminismo pro seu amigo macho que só sabe meter o pau no movimento, até isso é militância . $\underline{\text { O militar dá pra se fazer de várias }}$ formas. (grifos meus)

Em ambas as narrativas, o modelo do jovem militante aparece como um jovem que pensa primeiro no bem-estar da coletividade. Desta forma, a participação tem como mola propulsora o secundarizar seus próprios desejos em prol de atitudes e atividades que serviriam para transformar a sociedade. Assim, o desejo de transformação social passa a ser o desejo pessoal:

A busca por relações democráticas na ação política não se dá desvinculada
dos campos mencionados, pois os nossos gestos estão profundamente
vinculados aos nossos perceptos e afetos. Deste modo, a experiência
também oferece os elementos capazes de desconstruir os discursos dos que
fazem da democracia um mote de ocasião cujas palavras não se desdobram
em compromissos com a mudança das situações de desigualdades e
opressão. (DIAS, 2002, p.11)

Vejo que, ainda que altamente capturado, o mito do jovem enquanto militante serve também como potência, quando a militância passa a produzir mudanças também nas relações e nos espaços onde estes jovens se inserem.

O militante era o modelo de jovem que buscávamos produzir através do dispositivo da conferência. Este desejo estava atrelado à vontade de ter novas mãos, pés e cabeças, para ajudar a pensar e fomentar a luta pelas políticas públicas de juventude no município. Neste sentido, ainda que em espaços institucionalizados, buscávamos jovens de vários cantos da cidade para fazer coro na luta pelas políticas públicas de juventude. 
O jovem como alienado também aparece nas narrativas dos participantes e, como esperado, de forma antagônica ao jovem militante da década de 1960.

\begin{abstract}
Amanda: olha... eu enxergo a participação juvenil QUASE que insignificante... quase éh:.: insignificante no sentido de pequena... as poucas pessoas envolvidas... é como se o grito delas sumisse no meio da multidão... então o que eu tenho visto ahn::.: são/eu tenho uma filha... a filha do meu esposo... ela tem doze anos... as amigas delas todas participaram da manifestação éh:..... das últimas manifestações que tiveram... e a minha não foi porque eu sentei com ela e falei se você me responder algumas perguntas eu deixo você ir... e ela simplesmente não soube responder nenhuma... eu falei... bom se você não tem nenhum tipo de senso crítico você vai fazer o que nessa manifestação?... então você fica... você só vai o dia que você ... conseguir ter o mínimo de conhecimento que você está fazendo lá... e nenhuma tinha... então na verdade elas queriam ir para poder tirar um selfie e postar no facebook ((sorriu))... esse era o objetivo... então eu acho que isso ahn::: é um não objetivo... então eu acho que a participação política que... a participação que esses ((ruídos))... então assim eu acho que tem sido insignificante ahn::: muito mais por causa disso... porque são poucas as pessoas que têm participado e...: de fato mesmo... com um senso crítico... com ideias... com ideologia e tudo mais... são pouquíssimas... e acaba que 0 grito delas acaba sumindo na multidão... acho que isso precisa ser intensificado. (grifos meus)
\end{abstract}

Nesta narrativa, a afirmação "a participação juvenil é quase insignificante" mostra a ausência do jovem militante, visto pela entrevistada como um jovem crítico, com "consciência social" e com ideologia. Desta maneira, os jovens evocariam, conforme a narrativa, as características atribuídas ao jovem alienado: individualista, despolitizado. Isto observo na narrativa das motivações para participar de manifestações, onde o estar, para tirar foto para postar no facebook, ou ainda para contar aos amigos, assume um caráter de manifestação como produto a ser consumido e exibido, não sendo considerada pela entrevistada a possibilidade de sua ida a esse espaço se constituir como território de formação e informação.

A partir da experiência vivida como organizador das conferências, este sentimento perpassou em mim, acredito que até a $2^{a}$ Conferência Municipal, e é muito evidente em vários organizadores que, ao questionarem o número de participantes, costumam justificar a ausência de muitos jovens neste espaço atribuindo-a ao desinteresse e muitas vezes à alienação da realidade local, e ao comodismo.

O surgimento do jovem voluntário é apresentado por Groppo e Zamarian (2009, p.11, grifos do autor) ao dizerem:

Diferente do militante radical em prol de transformações gerais do modo de vida, mas também diversamente do estímulo à apatia política tão típica do neoliberalismo ortodoxo, a Terceira Via e suas variantes, que se tornaram a práxis hegemônica desde o final do século $X X$, incentiva a participação "comunitária", formas "positivas" de contribuição com a solução de questões 
locais focalizadas. Esta participação, ativa e "positiva", permitiria tanto comprometer o novo cidadão com a "concertação social", quanto de solver questões sociais sem apelar para a reconstrução de formas mais "sociais" de Estado e sem ameaçar o âmago do sistema sócio-econômico vigente.

Entre as principais mudanças entre o jovem militante e o jovem voluntário estaria a concepção acerca das exclusões sociais: enquanto para os primeiros a exclusão pode ser atrelada a questões relacionadas ao sistema capitalista, aos segundos as motivações para a exclusão poderiam estar no próprio excluído (GROPPO, ZAMARIAN).

Assumir o voluntariado, em contextos atuais, em especial aos jovens, seria uma forma de evitar o enveredar juvenil em problemas sociais, considerando que o voluntariado aos jovens surge como uma forma de ocupar o tempo livre (GROPPO, ZAMARIAN).

Para Groppo (2008, não paginado), ainda que "o voluntário tenha muito menos impacto transformador e desafiador que a militância, não se pode menosprezar os desejos mais ou menos ocultos de participação, de pertencimento presentes na disposição em ser "voluntário"”.

Nas narrativas, o jovem voluntário aparece no prisma do ator social, e considerando este discurso recorro a Souza (2006) para compreensão da produção do discurso do ator social:

De maneira geral, a expressão ator social refere-se, hoje em dia, àquele que trabalha pela consecução de objetivos pessoais numa dada conjuntura social e, por extensão, àquele que trabalha pela resolução de seus próprios problemas e daqueles que afetam a coletividade. Essa atividade do ator social, em prol de si mesmo e do grupo social, é o que faz dele um membro da sociedade. (p.63)

A autora destaca também, ao citar Touraine (1995), que "são necessários três ingredientes para produzir um ator social: objetivos pessoais, capacidade de comunicar-se e consciência social" e que o "ator social é aquele que, para conseguir alcançar objetivos particulares, modifica o 'entorno social' negociando com outros atores" (SOUZA, p.63-64). Ou seja, ser ator social não seria para qualquer um, sendo necessário o desenvolver de algumas habilidades. O apresentado por Souza é observado nas falas quando os entrevistados apresentam que:

Dandara: Eu acho que é, muito, um conhecimento político, você ter uma ideia, um conhecimento e um posicionamento. Isso eu sempre tive muita dificuldade, porque eu nunca tive posicionamento político enquanto questões partidárias, enquanto filosóficas, até mesmo. Então, eu acho que eu não conseguia fazer algumas participações por conta disso, porque essa estrutura 
de juventude, até mesmo, ela exige posicionamentos. Então, se você tem posicionamentos, você tem onde discutir. Se você não tem posicionamento, você não participa, você não se insere em determinados espaços. (grifos meus)

Hugo: Para mim participação juvenil é você se envolver desde o processo de elaboração, realização e avaliação de um projeto, de uma ação, eu acho que é você garantir a esse segmento juvenil de fato ser reconhecido como sujeito da ação, seja ela em qual sentido for, então a própria palavra 'participação' iá remete um entendimento de participar, mas eu sempre gosto de ampliar a ideia de participação porque muitas vezes o participar para alguns segmentos é só colocar o jovem lá, eu acho que não é esse o objetivo, e acho que a nossa conferência teve essa felicidade de realmente quase que, não me recordo exatamente quanto, mas tenho certeza que era a maioria de representação jovem organizando o evento, então acho que isso mostra o que é participação juvenil, você tem que ter sim a experiência do mundo adulto, vamos chamar assim, mas sem perder a essência de ter o jovem envolvido em todo o processo, porque senão sempre fica "para" e nunca "como", então... (grifos meus)

Davi: Participação juvenil para mim é o jovem estar ocupando o espaço dele dentro da sociedade onde ele possa ser ouvido... onde ele pode colocar seus anseios... suas vontades... se expressar principalmente... sem que seja taxado... né... isso para mim acredito eu que é ser/ter o seu espaço... ser jovem... (grifos meus)

Théo: Acho que... ah, acontece quando o jovem deixa de sair do seu... sabe, do seu local e começa a ir tentar ajudar as outras pessoas, buscar ajudar, buscar se interagir na política, buscar, sabe, o seu direito, o direito seu, sabe? Ir atrás dos seus direitos. Acho que é isso. Entendeu? (grifos meus)

Nas quatro falas é evidenciado que para o jovem desenvolver a participação ele precisa atuar, ocupar espaço, em outras palavras é preciso tornar-se visível.

Na fala de Dandara é salientada a capacidade de comunicar-se e a consciência social. Na fala de Davi, a capacidade de comunicar-se, enquanto Miguel e Théo ressaltam a consciência social e os objetivos pessoais. Interessante também, no exposto por Dandara e que ajuda a reforçar a necessidade destes três ingredientes, é que se o jovem não tem o "conhecimento político" e "posicionamentos políticos enquanto questões partidárias ou filosóficas", ele não consegue se inserir em alguns espaços, onde se cobra que o jovem assuma o papel de ator social.

Nas narrativas de Caio, bem como observado em outras narrativas oriundas de organizadores, é possível perceber uma das possíveis origens para este discurso do jovem participante como "ator social":

Caio: Creio mesmo que a participação se deu por conta de umas visitas que a gente fez em especial ao ETEC... né que acho que foi o que mais/não ETEC e Emilio Romi ${ }^{78}$ né... que foram as visitas que deram mais resultados assim e o pessoal foi participar lá... acho que foi éh:.: embora a divulgação tenha

${ }^{78}$ Refere-se à Escola Estadual Comendador Emílio Romi. 
deixado a desejar... ao meu ver foi devido a essas visitas mesmo. (grifos meus)

O jovem como ator social, nos espaços das conferências, pode ser construído pelo discurso dos organizadores durante a divulgação do evento, porém acredito que outros espaços como escolas e igrejas contribuem para construção deste modelo.

$E$, na narrativa que descreve o jovem como ator social, um outro enunciado é apresentado, segundo Souza (2006, p. 67). Trata-se do enunciado do jovem protagonista, ou o protagonismo juvenil, que é "um dos enunciados possíveis de um discurso que enfatiza a atuação social, ou seja, a atividade do ator social".

Este enunciado do jovem enquanto protagonista é construído e apresentado por organismos internacionais, porém também foi aceito e compartilhado por ONGs e acadêmicos.

\begin{abstract}
Convém salientar que a ideia de que todos os "atores sociais" devem "participar" na formulação e implementação de políticas, entre elas as de juventude, não aparece apenas nos documentos dos organismos internacionais, mas pode ser encontrada também nos textos e pronunciamentos das ONGs, órgãos de governos, membros da academia e empresariado. (SOUZA, 2006, p. 89, grifos do autor)
\end{abstract}

Neste enunciado, o jovem é visto conforme o referido autor como um recurso humano, onde se faz uma aplicação, durante o seu período de formação, para que mais tarde possa colher os lucros deste investimento.

Souza (2006, p. 92) destaca a origem do termo protagonista:

Praticamente todos os textos que se propõem a discorrer sobre o protagonismo juvenil - seja para defini-lo, enaltecê-lo ou criticá-lo mencionam as origens do termo protagonista: a junção dos vocábulos gregos prõtos (primeiro, principal) e agõnistës (lutador, competidor). Originalmente a palavra protagonista designava, portanto, o principal competidor dos jogos públicos, mas também de uma assembleia, reunião, luta judiciária ou processo. Isto é, encontra-se na formação inicial do vocábulo uma ideia ampliada de espaço público - como o lugar onde se tratavam batalhas tanto corporais quanto verbais. No teatro grego clássico, o termo passou a designar o personagem em torno do qual se construía toda a trama, aquele que desempenhava o papel principal na peça. O próprio discurso do protagonismo juvenil não permite que sejam esquecidas as origens gregas do vocábulo de que se apropriou. Mas o termo sofreu uma grande "assepsia", ou seja, uma apropriação que excluiu a noção de luta (agõnía) e aproximou a noção de espaço público à ideia de cenário teatral. Ou seja, no discurso atual, em que espaço público e cenário confundem-se, também não pode haver nítida distinção entre público e privado e entre política e encenação. 
Este enunciado do protagonismo juvenil é altamente propagado nos espaços das conferências e foi adotado nas políticas de juventude. Sua base se assenta na seguinte lógica, que Souza (2006) apresenta com base em documentos da ONU:

$\mathrm{Na}$ qualidade de recursos humanos "os jovens são uma força positiva na sociedade e [que] têm um enorme potencial para contribuir com o desenvolvimento e o progresso da sociedade" e a eles deve ser garantida a "plena participação [...] no desenvolvimento econômico e social". Os participantes do Terceiro Fórum Mundial da Juventude, do qual resultou o Plano de Ação de Braga, apontaram como objetivo explícito do encontro "promover a participação dos jovens no desenvolvimento humano, convencidos de que a participação social dos jovens é um requisito indispensável para o desenvolvimento de toda a humanidade". (p. 79, grifos meus $)^{79}$

A preocupação é com a integração da juventude pobre, especialmente dos países pobres, referidos como países "em desenvolvimento" ou "em transição para o desenvolvimento" [...] Sob a ótica do desenvolvimento humano, os textos em questão recomendam a integração econômica e social da juventude pobre como meio, inclusive, de assegurar a "coesão social". (p.75 e 78, grifos meus)

Em síntese, o modelo de participação juvenil proposto pelos organismos internacionais assenta-se sobre o princípio da atividade - o fazer coisas -, conjugado à passiva aceitação de diretrizes, critérios, regras e decisões já estabelecidas, permitindo a deliberação apenas sobre os aspectos técnicos, relacionados à operacionalização das políticas públicas. (p. 85 , grifos meus)

É interessante observar que, além de ressaltar a importância da participação juvenil, os excertos acima destacam que é o jovem pobre quem deve ser foco das ações que estimulem o protagonismo.

A narrativa do jovem protagonista aparece de forma implícita nas falas dos jovens participantes das conferências, em especial na fala do organizador Pedro, quando perguntado sobre a importância do espaço das conferências, e do organizador Davi, quando narra por que participou da conferência:

Pedro: O ponto principal que eu posso estar citando aqui é o engajamento real do jovem nas questões das políticas públicas para a juventude, quer dizer, para eles mesmos, vamos dizer assim, eles puderam estar dizendo "Eu faço parte desse segmento, e eu quero ver mudanças. Chega de vir as coisas de cima para baixo, eu também quero ser um protagonista", essa era a palavra que eu queria achar, o jovem realmente como protagonista das políticas públicas, queira no campo municipal, estadual e nacional, ele faz

79 ONU. Conferência Mundial de Ministros de Juventude. Declaración de Lisboa sobre políticas e programas relativos à juventude. Documento A/53/378, de agosto de 1998a. In: CEPAL e UNESCO. Protagonismo juvenil en proyectos locales: lecciones del Cono Sur. Santiago de Chile: CEPAL, 2001, Anexo, p.143-58.

Fórum Mundial da Juventude do Sistema das Nações Unidas. Plano de ação de Braga sobre a juventude. Braga, Portugal, agosto de 1998b. In: CEPAL e UNESCO. Protagonismo juvenil en proyectos locales: lecciones del Cono Sur. Santiago de Chile: CEPAL, 2001, Anexo, p.159-70. 
parte. E principalmente ele pode estar apresentando ali as suas ideias, as suas temáticas, enfim. (grifos meus)

Davi: Ahn::: eu sou um/era um jovem que participava da pastoral da juventude... e nós tínhamos um sonho que nós começamos a construir... um grupo de pessoas a qual fazia parte eu... Rodrigo...Eu...Pedro... e mais alguns jovens da/do nosso município... de ser protagonistas da juventude no nosso município... e dentro desse projeto... que iniciou lá nos meus quinze anos de idade... éh::: a conferência foi uma das portas que nos abriu para que a gente inserisse esse projeto...

$\mathrm{Na}$ fala de Pedro, a conferência como espaço de participação juvenil é também o espaço onde protagonismo juvenil pode ser gerado e desenvolvido, o que é evidenciado na fala de Davi, ao narrar que seu grupo de amigos concretizou seu protagonismo na participação juvenil através da conferência.

Esse convite ao protagonismo e também à militância era por nós propagado a partir de documentos institucionais que serviam de base para disparar o processo das conferências, oriundos da SNJ, do CONJUVE, e também por nós produzidos dentro da Pastoral da Juventude. Então, ao confrontar as falas de participantes e organizadores com minhas memórias, vejo que, ao fazer o convite aos jovens para participar das conferências, na verdade fazíamos um chamamento destes jovens para assumir a militância e serem protagonistas, por mais contraditório que o uso destas duas identidades possa parecer.

Hoje problematizo a partir de Souza (2006) que, talvez, diferentemente do exposto por Davi e Pedro, os verdadeiros protagonistas são os organismos internacionais, tendo em vista que os espaços das conferências surgem a partir do apontamento destes organismos da necessidade de criar espaços onde os atores sociais podem "participar na formulação e implementação de políticas" (SOUZA, 2006, p.89). Este indicativo foi incorporado pelo governo federal no desenvolvimento das políticas públicas de juventude. Porém, isso não minimiza os esforços, e as possibilidades construídas nestes e em outros espaços de participação.

Nesta narrativa de participação juvenil apresentada até aqui, a conferência torna-se um dispositivo de produção de subjetividades, pelo qual os jovens são subjetivados como militantes, alienados ou protagonistas. Tais subjetivações são produzidas a partir do discurso de organismos internacionais, ONGs, governos e até mesmo movimentos sociais juvenis que juntos formam o elenco da sociedade civilio.

${ }^{80}$ Sociedade civil como elenco e a sua composição são apresentadas por SOUZA (2006). 
No espaço das conferências de juventude, os participantes são fixados de forma binária como sociedade civil ou poder público. Em suma, de um lado é posto quem governa e controla a execução das políticas públicas, ou presta os serviços. De outro lado, a sociedade civil, que representa quem é o receptáculo dos serviços prestados pelo governo, que neste cenário deve apontar o que ele (governo) deve fazer para deixar de ser um prestador de serviço ineficaz. Essa é a função do jovem protagonista que exerce a participação juvenil. "Nessa sociedade sem garantias, compete ao indivíduo [jovem e sociedade civil] atuar (trabalhar, negociar, defender, realizar, fazer) para obter acesso a serviços que atendam às suas necessidades de sobrevivência ou de 'inclusão'” (SOUZA, 2006, p. 93, grifos do autor).

Essa imagem do que é ser protagonista é identificada na fala de alguns entrevistados que também elencaram onde e como se dá o protagonismo juvenil:

Pedro: Participação juvenil é quando um grupo por menor que seja, ele sente, possa estar sentando, conversando e realmente mostrando que ele quer participar do espaço, ele quer espaço para essa juventude, ele quer se fazer presente, ele quer discutir, ele quer conversar, ele quer apresentar as suas ideias, ele quer dizer o porquê não concorda com aquilo. Então eu vejo a participação juvenil hoje não como quantidade, mas sim pela qualidade do grupo que está participando, e isso que eu vejo que em Santa Bárbara não tem aquela quantidade massiva, mas nós podemos hoje estar verificando que existem vários grupos, várias pessoas que estão sim discutindo políticas públicas dentro do seu segmento, dentro do seu grupo, quer que seja grupo de trabalho, de escola, grupo de diversão, enfim. Hoje acredito que o jovem ele já conversa ou consegue conversar sobre políticas públicas de juventude no município, já consegue falar políticas públicas de uma maneira diferente, não aquela coisa que a gente vê na televisão, por exemplo, ele já consegue realmente entender o que é essa política de juventude que é voltada para ele mesmo. (grifos meus)

Caio: Nossa... ((sorriu)) e agora? bom... participação juvenil para mim é o primeiro contato que eu obtive foi sim a participação do conselho... então sendo conselho pra mim o primeiro espaço que eu vi pra isso... participação juvenil é:.: a juventude se imbuir e tomar conta desses espaços... é::: mais fácil certamente quando eles já são criados previamente como um conselho... como uma conferência... mas éh:..... é a juventude tomar partido... é na participação éh local né... seja qual nível for... municipal... estadual ou federal... éh::: é a juventude com a sua simplicidade com... mas com a sua enorme carga assim de desejos e de ambições é ocupar esses espaços e questionar... colocar sua opinião éh.:. deixar claro seus anseios éh... e daí é interessante que pra que isso seja mais facilitado... que mais espacos pra participação juvenil sejam criados né... sejam eles conselhos... sejam eles conferências e tudo mais. (grifos meus)

Davi: Eles... eu acredito que eles não estão desenvolvendo a participação juvenil... eles têm um espaço para eles... mas eles não estão sendo protagonistas de criar algo para eles... de ir lá e falar "ah eu quero isso... isso não está legal... olha vamos construir dessa forma..." não... eles vão lá usufruir dos espaços que foram conquistados por outros jovens que aí sim participaram de um movimento... quando eles participam para mim das conferências... eles estão fazendo parte... eles estão ocupando o espaço juvenil né... aí eu acredito... quando ele participa de um conselho como o da 
juventude... ele está dentro de um espaco juvenil... agora na cultura... nós não temos jovens atuando... no esporte nós não temos jovens atuando... no:.:: CMDCA que é o Conselho Municipal de Direito da Criança e do Adolescente nós não temos adolescentes que participam... então eles não ocupam os espaços que são destinados a eles... então protagonismo juvenil no nosso município... nós temos muito pouco... muito pouco mesmo né... muito né... são poucos jovens que estão interessados e acredito eu por não ter divulgação adequada... não saber... muita gente aqui não sabe como participar... e basta dar um pouquinho de oportunidade para eles que a gente vê que eles participam sim. (grifos meus)

Lara: Um jovem ativo na sociedade. Bom, primeiramente votando, né? Exercendo esse direito que ele tem e participando das... de conferências e de.. é... eventos voltados para os jovens e também tentando ver... começar a ver a questão de cuidar do município como um trabalho dele também, que não é um trabalho só pros adultos fazer, tipo, ele participar de... de que tem de terça-feira na Câmara, tudo essas coisas, ele pode ir lá, ver o que tá acontecendo, ele ser ativo mesmo, ele ver o que acontece no município, não só no mundinho dele. (grifos meus)

Félix: Participação juvenil é a participação realmente das pessoas... mais precisamente dos jovens na questão política... Entendeu... eu acho que para mim participação juvenil é isso... os jovens de maneira geral... para mim jovem não é só adolescente sabe... mas por exemplo uma criança de dez anos... inclusive... saindo um pouquinho fora.

Miguel: Eu participei de um grupo que é do... de alguns youtubers, que é o Canal das Bee, que eles, que eles têm esse grupo nas redes sociais e ali eu comecei a conversar com outros militantes e fui interagindo e isso foi me dando mais força para poder buscar alguma coisa para dentro do município. Uma forma de interação que eu achei bem legal foi a conferência. Ali a gente colocou propostas, colocou visões que nós, jovens, temos para levar para o poder público. E dessa maneira eu acho que a gente consegue mais informações e também levar informações do que realmente a sociedade está precisando, para o poder público. Através também dos manifestos que tem, de rua, acho também válidos, mas não tanto quanto uma conferência onde o poder público dá mais visão e dá um enfoque um pouco maior. (grifos meus)

Théo: Ah, participação juvenil para mim é o jovem buscar saber o que está acontecendo na sua região, na sua cidade, o que ele pode fazer para mudar isso, entendeu? O que ele pode fazer para ajudar, tipo, o seu vizinho que está do seu lado, o que você pode fazer para ajudar o seu vizinho. Ele buscar se inteirar... se inteirar, eu acho que é se inteirar sobre a sua cidade, o que está acontecendo com ela, entendeu? Ele buscar tentar ajudar a sua cidade, acho que é isso (grifos meus).

Ao identificar os espaços de atuação do jovem protagonista, os participantes estão fixando os espaços onde pode se dar a participação juvenil.

Pedro vê potência no protagonismo juvenil ao tentar desenhar um novo jeito de fazer política, resistindo ao propagado pela mídia, e amplia os cenários de fazer política deste ator social. Porém, de modo geral, a participação é vista a partir de espaços instituídos como se apresentam nas narrativas de Caio e Davi. Para Davi, a participação juvenil só é possível a partir do protagonismo juvenil, que é indissociável 
da arena política, sendo que para atuação do jovem é necessária a concessão de oportunidade ou a criação de espaços. Para Borghossian e Minayo (2009),

o protagonismo pressupõe a criação de espaços e mecanismos de escuta e participação dos jovens em situações reais na escola, na comunidade e na vida social, tendo em vista tanto a transformação social como sua transformação integral. (BORGHOSSIAN; MINAYO, 2009, p. 416)

Lara reafirma a necessidade de atividade para ser protagonista, e, como Davi e Caio, atrela a participação juvenil a cenários da arena política. Para Davi, o protagonismo não se concretiza em qualquer lugar, ficando condicionado a espaços formais de participação como conselhos e conferências. Porém este sentido de participação a partir de espaços institucionalizados, ainda que se vislumbre potência em meio à captura, deve ser problematizado, a partir do exposto por Guizardi (2014,p.26):

Neles, o poder de constituição inerente às relações humanas perde sua radicalidade de fundamento, tornando-se procedimento contratual, e deixa de ser temporalidade e espaço abertos e extensivos da produção de realidade social, a fim de ser exercido nos limites normalizados de finalidades instituídas, convertendo-se em ordem formal.

Félix e Théo narram a participação juvenil como "consciência da realidade", próximo do que Amanda chama de "consciência política", que permite ao partícipe do processo saber avaliar o que é posto e não ser conduzido por discursos de massa. $O$ narrado por eles aproxima-se do exposto por Souza (2006), segundo o qual a partir da consciência social se desencadearia a atuação sobre este entorno.

Miguel difere dos demais ao sugerir novos espaços onde a participação juvenil pode ocorrer, entre eles a cibermilitância.

Para além dos sentidos da participação juvenil, vejo como interessante problematizar que nos relatos não são feitas diferenciações entre os tipos de participação, tais como apresentados por Bordanave (1994) ou por Leon, Dolejsiová e Falangola (2009). Em geral, o sentido que os jovens entrevistados manifestam em relação à participação está associado aos conceitos de participação social e participação política, vistas como sinônimos, como já apresentado em Guizardi (2014).

Faço tais observações a partir dos espaços e sentidos atribuídos aos entrevistados ao abordar este território, em especial quando referenciam espaços de participação institucionalizados. 
Porém, as narrativas sobre participação juvenil dos entrevistados não se limitaram ao discurso hegemônico do protagonismo juvenil em cenário ou arenas políticas.

Ainda que nas falas seja possível identificar os ingredientes que formam o ator social, encontram-se também a possibilidade e a tentativa de escapar à captura da narrativa do protagonismo juvenil, e da arena política, redesenhando o sentido de participação juvenil.

Thaís: Então, é assim, é muito difícil, porque é como eu disse, os jovens têm muitos grupinhos, tem grupo que é mais esperto, tem outro que não está nem aí. Então, a participação do jovem não tem como definir, depende do grupo que você está lidando. Não tem como. Tem o grupo dos skatistas, tem o grupo dos baladeiros, tem o grupo dos funkeiros. Dos skatistas é assim, cada um quer o seu objetivo, né? Os skatistas querem as pistas deles, a liberdade deles. Os funkeiros querem ficar na frente do Tivolis1, quer ligar o som alto, querem ir lá na frente do Fórum. Os baladeiros querem balada, querem que liberem balada em Santa Bárbara, que não tem, porque não pode fazer, entendeu? Tinha balada, antes, em Santa Bárbara, não pode ter mais. Nenhuma casa pode abrir balada em Santa Bárbara, porque é proibido. Ninguém dá o alvará, então cada um tem o seu objetivo e o jovem, na verdade, o que eu vejo, ele, realmente, o que mais quer é diversão, é coisas assim, não vai ficar lutando por coisas tipo saúde, porque não está precisando. Quando começar a afetar ele, que ele vai começar a querer. Só vai atrás do objetivo que afetar ele, entendeu? E, na cabeça de jovem é isso que tem em mente, né? É diversão, é festa, essas coisas. (grifos meus)

Para Thaís, a participação juvenil tem sentido de "o que a juventude quer fazer?". A partir dessa pergunta, cada um desenha a sua participação e seus espaços de participação, em uma decisão que corresponde a si e aos grupos de amigos ou associações com quem o jovem deseja atuar e viver.

A participação aqui é vista no aspecto do lazer, do tempo e da experimentação e tem um caráter fluido, difuso, próximo da ideia de participação rizomática apresentada por Quintanilha e Dalbello-Araujo (2014).

A participação rizomática é caracterizada por acontecer para além dos espaços instituídos, considerando que muitos desejos de participação não se encaixam nos espaços institucionalizados (QUINTANILHA; DALBELLO-ARAUJO). A participação rizomática parte daquilo que afeta o jovem.

Surgem, como modelos alternativos, as possibilidades de participação que podem não representar a totalidade dos jovens.

\footnotetext{
${ }^{81}$ Shopping center localizado na cidade.
} 
A visão apresentada por Thaís destoa da ideia de protagonismo juvenil, pois o olhar sobre este depoimento resgataria as conotações atreladas ao desejo, indo na contramão do discurso do protagonista.

Tom: Pelos jovens, a participação em alguma coisa, a participação dos jovens, vai... Resumindo, a participação juvenil é a participação dos jovens, participação...Qualquer coisa. É a participação juvenil, ir num campo de futebol, fazer parte de um grupo, é uma participação. A participação na política. Qualquer coisa, participação juvenil.

Durante a entrevista, em algumas perguntas, Tom ficou inseguro, e transmitia o desejo de responder de forma breve para passar para a próxima. Isto ocorreu quando indagado sobre a participação juvenil. Ainda assim, ele traz uma ideia de participação juvenil próxima da apresentada por Thaís, como sendo qualquer atividade feita e realizada pelo jovem como produtora de participação juvenil, constituindo-se em leque amplo de espaços que passam pela prática esportiva, pelo encontro com outros jovens e também pela política, como também apresentado por Elis.

Elis: De conferência da juventude não, eu participo de algumas assembleias, tanto é que amanhã vai ter uma assembleia pública sobre a reorganização escolar, a gente fez um protesto esses dias, foi numa quartafeira passada, a gente fez um protesto, foi às ruas, fez da praça central até o ministério da educação, aquele que é do lado do Heitor, ali pra cima, secretaria da educação, a gente saiu da praça do centro e foi até lá, saiu no jornal e tudo mais. Eu acho que, primeiro de tudo, pra mim, que venho fazendo coisas em praça pública em outros movimentos assim, é a ocupação de espaço, independente de qual seja, se seja vim andar de skate na pistinha que tem aqui ou seja vim fazer uma oficina oferecida aqui e depois, sei lá de grafite e deixar sua marca no muro, fazer lambe e distribuir por aí, fazer adesivo, é você fazer um desenho e divulgar na internet, é, eu vejo por mim e pelo meu meio, é muito produção e a divulgação dessa produção, colocar isso pra fora e fazer as outras pessoas verem. Mas existe várias formas também, tem muita gente que se expressa pela literatura ou se expressa em próprias conferências ou em assembleia, dentro de outros movimentos, então a participação juvenil pode tá de várias formas, o que eu tô mais acostumada é essa questão de produção cultural e colocar isso pra fora. (grifos meus)

Elis, que em vários momentos da entrevista ressaltou sua participação no município vizinho, em detrimento de Santa Bárbara d'Oeste, foi indagada sobre seus espaços de participação. Neste momento ela traz uma concepção de participação, a partir das arenas políticas, com forte atuação de movimentos sociais. Porém sua fala evidência a possibilidade de uma participação rizomática que se dá a partir de expressões culturais, o que está diretamente associado aos seus espaços de vivência e atuação. 
Neste sentido, a participação rizomática surge a partir da rebeldia juvenil, como forma de resistência, sendo caracterizada por "não ter uma forma preestabelecida de existência ou ocorrência, podendo emergir como movimentos de resistência, nos quais ganha forma, corpo e pode ser percebida" (QUINTANILHA; DALBELLOARAUJO, 2014, p. 100).

Saliento que uso o termo rebeldia não em seus sentidos pejorativos comumente atribuídos à juventude, mas como sinônimo de resistência, ou seja, como ato de rebelar-se, como teimosia ${ }^{82}$.

Sobre a resistência, Quintanilha e Dalbello-Araujo (2014, p.99) afirmam que é "fruto de determinada reação, pois ela pode ser o resultado de um somatório de forças". No caso da juventude, como apresentado por Elis, isso ocorreria a partir das relações produzidas por jovens em diversos espaços.

A resistência estaria então na tentativa de escapar às formas e aos modelos de participação pré-estabelecidos. A participação rizomática produz então espaços lisos de participação em oposição aos espaços estriados produzidos pela participação institucionalizada. O conceito de espaço liso e estriado é retomado do proposto por Deleuze e Guattari (1997, p. 157):

O espaço liso e o espaço estriado, - o espaço nômade e o espaço sedentário, - o espaço onde se desenvolve a máquina de guerra e o espaço instituído pelo aparelho de Estado, — não são da mesma natureza. Por vezes podemos marcar uma oposição simples entre os dois tipos de espaço. Outras vezes devemos indicar uma diferença muito mais complexa, que faz com que os termos sucessivos das oposições consideradas não coincidam inteiramente. Outras vezes ainda devemos lembrar que os dois espaços só existem de fato graças às misturas entre si: o espaço liso não para de ser traduzido, transvertido num espaço estriado; o espaço estriado é constantemente revertido, devolvido a um espaço liso. Num caso, organizase até mesmo o deserto; no outro, o deserto se propaga e cresce; e os dois ao mesmo tempo. Note-se que as misturas de fato não impedem a distinção de direito, a distinção abstrata entre os dois espaços. Por isso, inclusive, os dois espaços não se comunicam entre si da mesma maneira: a distinção de direito determina as formas de tal ou qual mistura de fato, e o sentido dessa mistura (é um espaço liso que é capturado, envolvido por um espaço estriado, ou é um espaço estriado que se dissolve num espaço liso, que permite que se desenvolva um espaço liso?).

Assim como o espaço liso se transforma em espaço estriado e vice-versa, acredito que o conceito de participação rizomática pode ser visto dentro do espaço estriado das conferências, quando os jovens reinventam as formas de participar, os sentidos e significados das conferências de juventude. Está aí a rebeldia e a

82 Os termos associados à palavra rebeldia foram retirados do Dicionário da Língua Portuguesa, Porto Editora. 
resistência da juventude, ao participar dos espaços da conferência: redefinindo sentidos e escapando às capturas impostas neste espaço e por grupos vistos como "politizados" e como "mais preparados". Essas possibilidades de resistência e de ressignificação dos espaços de participação revertem a lógica dos espaços instituídos vistos como mais adequados à participação juvenil.

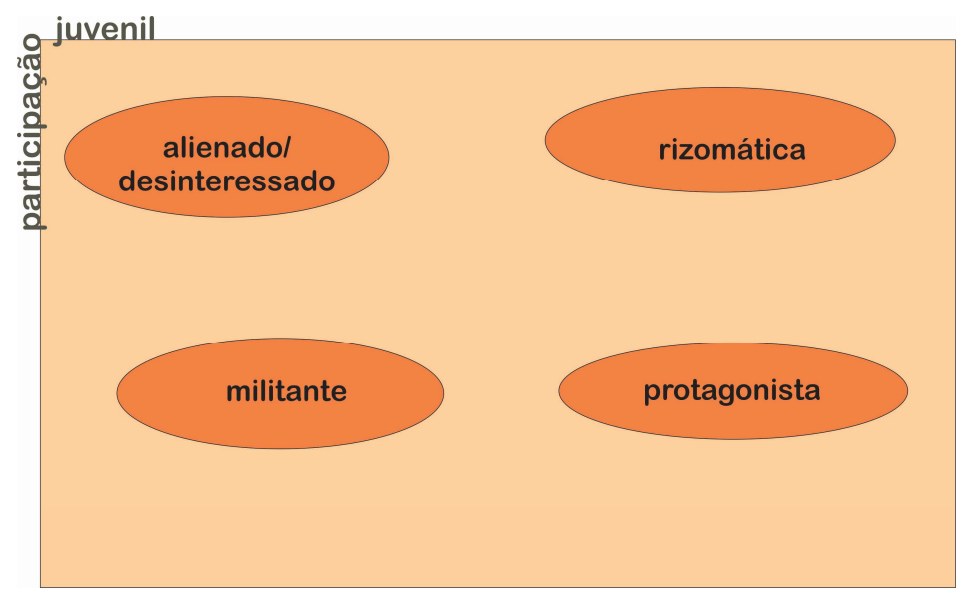

Figura 15 - Sentidos atribuídos à participação juvenil

Ao confrontar os diferentes sentidos da participação juvenil a partir das conferências, apresentados na figura 15, penso que os sentidos surgem de forma contraditória.

\begin{abstract}
A participação torna-se complexa, carrega ambiguidades. Ora pode ser o nome apenas para a fixação das pessoas em programas pretensamente inovadores. Em outros momentos, oferece as condições para que deslocamentos de fato sejam feitos. Os riscos são inevitáveis. Vai-se aprendendo a lidar com eles na medida em que se vai fazendo, avaliando, revendo, todo o tempo, em uma atividade incansável. (DIAS, 2002, p.13)
\end{abstract}

Assim, ao mesmo tempo em que fixa o sujeito e os lugares da participação juvenil, a participação tem produzido resistências e rebeldias. A partir do colocado por Dias, penso que problematizar a participação juvenil a partir da participação rizomática só me foi possível após estas leituras e as tentativas de voos e pousos que foram feitos ao longo desta pesquisa, mas também ao longo de minha trajetória de pesquisador militante. Possivelmente a minha visão a respeito da participação juvenil nas duas primeiras edições das conferências, antes do ingresso no mestrado, esteja mais próxima da visão da participação como jovem militante e protagonista, com os espaços de participação muito bem demarcados. Porém os voos e pousos hoje me permitem avaliar a participação juvenil de forma mais plural, tanto em seus sentidos, quanto em seus espaços de ocorrência. 


\subsection{2 - Os porquês da participação juvenil em Santa Bárbara d’Oeste}

Ao cartografar as motivações, novamente aparecem as narrativas do jovem como protagonista, resgatando os sentidos e o desejo em ser ator social:

Davi: Ahn... eu sou um/era um jovem que participava da pastoral da juventude... e nós tínhamos um sonho que nós começamos a construir... um grupo de pessoas a qual fazia parte eu... Rodrigo...Eu...Pedro... e mais alguns jovens da/do nosso município... de ser protagonistas da juventude no nosso município... e dentro desse projeto... que iniciou lá nos meus quinze anos de idade... éh... a conferência foi uma das portas que nos abriu para que a gente inserisse esse projeto... foi ali que também me tornei conselheiro tutelar né... vindo desse projeto... então tinha assim então o conhecimento do/da falta de políticas públicas para os jovens do meu município e sabendo que ahn... a conferência era aonde a gente pode se concentrar e fazer com que o jovem seja ouvido... não tinha como eu ficar fora. (grifos meus)

Lara: Porque eu acredito que se eu quero a mudança, eu tenho que ser a mudança e eu vi a conferência como algo que ajudasse a mudar alguma coisa no município... Bom, tem muitas coisas que eu gostaria de mudar, mas eu acho que o mais importante tipo no momento pro município é.. pro município e pro Brasil inteiro também seria a educação e, também, questões culturais, porque dentro da cidade a gente tem alguns principais roteiros culturais que seria o Via Crucis e, depois, seria a Virada Cultural e não tem mais quase nada, então acho que poderia ser uma mudança também (grifos meus).

Félix: Porque assim.... na verdade eu gosto dessa área sabe... eu quero me tornar um dia quem sabe um pedagogo... um sociólogo sabe... e eu resolvi participar para conhecer mais a fundo e também expor minha opinião sobre né... porque hoje infelizmente... que foi muito debatido lá... não há nada para o jovem né... há o shopping... mas eu acho que assim... inclusive vou por uma fala do jovem... não vou me lembrar o nome agora... "shopping não é lugar de criança" né... não é lugar de jovem também né... então aonde o jovem vai... vai procurar um lugar para se divertir né... (grifos meus).

Théo: Ah, eu acho que a gente pensou que a gente quer uma cidade melhor e a gente quer um país melhor. Então a gente está tentando buscar isso, não é? E acho que devia ter mais jovens interessados nisso. (grifos meus).

Vejo como interessante, nas falas acima, que o descontentamento com a realidade do município no que tange à vida da juventude surge como um descontentamento impulsionador no surgimento de jovens protagonistas e da participação juvenil, uma vez que os jovens participantes passam a reconhecer o espaço das conferências como um espaço onde há a possibilidade de apontar quais mudanças se quer e o que não está a contento.

Isso se aproxima do que nós, enquanto organizadores, pensávamos, ao realizar as conferências na cidade. Víamos na constituição deste espaço a possibilidade de criar um canal tanto para chamar o jovem ao debate da política e da 
construção das políticas públicas de juventude no município, bem como uma possibilidade de, nas relações de poder com o poder público, incluir a juventude na agenda das políticas públicas municipais.

Como problematizado anteriormente, talvez esse discurso tenha sido assumido pelos jovens participantes a partir da estratégia de divulgação, e nós, enquanto organizadores, conhecendo a realidade do município, em especial quanto aos espaços de lazer para a juventude, utilizamos deste argumento para instigar o descontentamento dos jovens, reafirmando a conferência como um espaço para este fim. Isto é narrado por alguns organizadores, quando falam sobre os motivos que teriam levado os jovens à participação nas conferências de Santa Bárbara, como identifiquei nas falas abaixo:

Pedro: Olha, a principal questão que eu vejo aí foi realmente, houve uma motivação da comissão organizadora em estar buscando esse jovem em vários segmentos, na escola, comunidades religiosas, locais de diversão e tudo mais, convidando eles para que pudessem estarem vindo, dar uma palavrinha com a gente, mostrar um pouco quais são os seus anseios. Mas eu acho que a principal questão aí nesse momento em Santa Bárbara foi através da motivação de estar levando para eles o que é, o que seria essa conferência, 0 que eles poderiam estar fazendo nessa conferência e 0 principal seria o fato de estar podendo dar voz para eles na questão da juventude no município. (grifos meus)

A familiaridade com o tema "política", estando ou não em grupos, coletivos ou movimentos juvenis, pode ser vista como alguns dos motivadores de participação dos jovens que já estão engendrados na lógica do ator social ou protagonismo juvenil.

Dandara: Outras pessoas já estavam envolvidas em movimentos de juventude há mais tempo. Então, que seja um movimento de juventude de caráter religioso ou que seja de um movimento específico. Então, essa era umas das características, mas no caso desse grupo do IRSSA, mesmo, era porque a gente queria discutir outras coisas, que a gente viu aquela possibilidade naquele espaço. (grifos meus)

Caio, que anteriormente destacou os esforços de divulgação dos organizadores, reconhece este fator:

Caio: A presença desses jovens específicos se deve ao fato de jovens que já têm de antemão algum interesse ou algum desenvolvimento éh::: pessoal na questão de questionamento político e de funcionamento institucional $\mathrm{e}$ tudo mais... ou seja são jovens que já possuem/possuíam esse::: esses conhecimentos... essas inquietações e::: o convite foi um gatilho para que de fato eles eles participassem. (grifos meus)

Amanda: Olha... os que estavam envolvidos ali no processo... eu acredito que de forma geral... pelo menos envolvidos com questões políticas... interesses com... éh com algum ponto específico da cidade... eles já 
estavam... mas eu acredito também que assim... ahn... alguns ali... eles estavam tentado descobrir o que de fato era essa conferência... (grifos meus)

Outro sentido encontrado na participação juvenil é a participação imposta (BORDENAVE, 1994), ou seja, motivada por atuação de outros atores, que levaram o jovem à participação por meio de estratégias de domínio, por exercerem algum poder sobre este jovem. E, neste aspecto, chama à atenção a fala de uma participante, ao afirmar que em 2011 alguns jovens ligados à igreja católica não teriam ido de forma espontânea, mas teriam participado por obrigação da coordenação da Crisma.

Thaís: só que eu acho que os outros jovens foram, mesmo, por obrigação da Crisma, sinceramente.

Esta fala foi confirmada pela coordenação da Crisma, que não descreve o encaminhamento do jovem à conferência como obrigação a ser cumprida, mas como um incentivo e motivação para participação.

\begin{abstract}
Melissa: Eu senti que houve um convite né a princípio da própria coordenação... a gente éh... montou ônibus... montou estrutura... falou que ahn::: ia ser um dia diferente.... que a gente iria estar indo para lá ao invés de ficar dentro das salas como costumeiramente fazíamos... e:.: a gente propôs como uma atividade diferente... para que eles também conhecessem o que existe lá fora né... além da crisma né... além da/do que tem que é os ensinamentos religiosos... e... também se engajassem nesse sentido... a questão deles estarem indo eu senti que não foi talvez cem por cento que eles quisessem estarem indo... tanto que convidamos Boa parte e uma boa parte não foi... pelo menos no (CAIC) né... na primeira edição que eu participei... mas éh... como foi meio que imposto... boa parte acabou indo...(grifos meus)
\end{abstract}

Ainda que a maior parte dos participantes da entrevista não relate essa circunstância, é tácito pelas duas falas que em alguns grupos ocorre de a coordenação ou lideranças colocarem a participação como imposição para os jovens. O contato feito pela comissão organizadora com a Pastoral da Crisma foi para a liberação dos crismandos dos encontros de Crisma, que ocorriam aos domingos, para que os mesmos pudessem estar no espaço da conferência.

Como observado na narrativa de Melissa, a liberação ocorreu pela proximidade dos coordenadores da Pastoral da Crisma com os organizadores da conferência e por acreditarem que a participação destes jovens Ihes proporcionaria possibilidades de conhecer e debater a realidade da juventude no município, abrindo possibilidades de inserção pós sacramento da crisma. 
Porém, mesmo sendo uma imposição, nem mesmo assim os jovens aceitam esta condição, e escapam. Talvez o fato de ser uma obrigação em alguns espaços torna-se um atrativo à não participação.

Vejo também que a imposição não seria o único estimulador da participação, pois o aceite a esta circunstância pode estar associado a motivos de outra ordem também, existindo alguma espécie de desejo que possibilita aceitar este jogo de poder, relativizando a suposta imposição.

Observo que, entre os entrevistados, os religiosos, por exemplo, veem a conferência como espaço de oportunidade para os jovens e, portanto, não somente criam condições para a participação, mas também manejam uma certa imposição a qual os jovens resistem ou aceitam a depender de seus interesses, contextos e momentos.

Penso também que esta participação se deu por enxergarem no espaço da conferência um espaço de possibilidade de participação para atender projetos com objetivos pessoais ou também coletivos, no caso dos jovens associados a grupos ou coletivos, como observei em trechos que apresentei acima e como nos trechos narrados abaixo:

Dandara: Eu acredito que, primeiro, porque era um espaço de possibilidade. Levantava-se alguns temas e algumas questões que outros espaços não levantavam. Então, supria algumas coisas que, por exemplo, a escola não trazia. A gente queria falar sobre alguns conflitos que nós vivíamos e que a escola não comportava, até porque a visão que eu tinha era que, partindo do meu ponto de vista, supria essa característica. (grifos meus)

Elis: Olha, eu falo por mim, como eu já tô envolvida nesse meio, principalmente da juventude, produção cultural, por mim, eu acho muito importante não só de levar o meu projeto pra frente, mas também de saber quem é as pessoas que estão produzindo alguma coisa, de saber quem é a juventude que tá se movimentando, tanto em produção ou só de tá participando mesmo, de tá vendo e apreciando e eu como moradora de Santa Bárbara sempre participei muito mais ativamente de Americana do que de Santa Bárbara, então, pra mim, é mais reconhecer quem é a juventude da minha própria cidade. (grifos meus)

Thaís: Eu fui porque eu estava interessada no assunto. Eu fui por causa disso... E eu também estava fazendo o trabalho de TCC, que era: "por que o Brasil não tem indignados". Eu achei que iria agregar valores ao trabalho $e$ ajudar. (grifos meus)

Miguel: Bom, a princípio, eu resolvi participar porque acho que já... era alguma coisa que estava entranhado dentro de mim e eu acho que já queria participar de algum meio político para tentar interagir um pouco mais. (grifos meus)

Fica evidenciado que estes jovens viram na conferência uma possibilidade no espaço, para atender demandas de ordem pessoal, seja através da ampliação da rede 
de contatos e dos encontros com outros jovens com os mesmos objetivos, seja para encontrar no espaço da conferência um espaço de formação, seja para desenvolvimento de trabalhos escolares ou de inserção na militância. Trata-se da vivência do processo democrático construindo e produzindo devires.

\begin{abstract}
A palavra que melhor sintetiza o processo de democratização vivido é realmente a participação. Em cada relato de experiência se vai tendo acesso a aspectos e facetas do que constitui a participação em um contexto específico, envolvendo elementos da cultura e da história locais. Assim, vamos nos convencendo de que é impossível definir a participação como um conceito político fora dos dados de realidade. É nas múltiplas faces do real com as quais a participação se relaciona, que vamos identificando o devir democrático de uma dada comunidade. (DIAS, 2002, p. 46-7)
\end{abstract}

Mesmo diante das capturas deste processo democrático participativo das conferências, consigo visualizar o desejo da construção de um mundo melhor a partir da inserção dos jovens, que não necessariamente estão estipulados ou controlados pelos agentes que ditam o protagonismo juvenil.

Ainda que exista a captura na intenção de participação nas narrativas apresentadas, é possível sim identificar tentativas de resistências através do desejo de mudança e de estar com iguais, que é emanado pelos entrevistados. Independentemente da motivação que os levou a participar da conferência, ou do sentido que atribuem à participação juvenil, a mudança está na maneira como resistem o que é feito a partir da leitura de mundo, da formação que tiveram, ou seja, a partir dos espaços nos quais foram subjetivados.

A participação juvenil a partir das conferências, quando verifico o que levou os jovens a dedicarem a elas um sábado ou domingo de manhã, ou o dia inteiro, se deve ao fato de enxergarem virtude, possibilidade ou potência neste espaço para realizar projetos, com objetivos de ordem pessoal, ou também coletivos, quando estes estão associados e traduzem o sentimento de pertencimento a algum grupo. Estes desejos e olhares de possibilidade possivelmente não são os mesmos que nos levaram a organizar as conferências, mas o encontro destes desejos é o que me tem possibilitado narrar estes espaços, vislumbrando nossas rebeldias e tentativas de escapar às capturas presentes neste espaço, que muitas vezes foram por nós reverberadas.

Quem participa tem o desejo de falar, de ouvir, de estar na presença do outro e, no meio disso tudo, se divertir. E nestes desejos encontro a potência na participação juvenil aqui apresentada. 
A seguir, abordarei o terceiro território investigado: o território das conferências, onde buscarei sobrevoar e pousar para cartografar como os participantes tiveram conhecimento da conferência, os sentidos e significados a atribuídos a este espaço de participação, e quais as dificuldades e desafios para realização de novas edições.

\subsection{Conferência}

\subsection{1 - $\quad$ Conhecimento da Conferência}

Em um primeiro momento, decidi diferenciar o conhecimento da conferência entre os organizadores e participantes.

Para exemplificar, entre os organizadores resolvi recorrer às falas de Pedro e Davi, que remetem às origens e a como se obteve conhecimento para organizar a $1^{\text {a }}$ edição da Conferência:

Pedro: Bom, na realidade eu fiquei sabendo por um grupo da Pastoral da Juventude, que estava mais inteirada na questão, eles foram conhecer uma conferência fora e trouxeram a novidade para o nosso município, até então nunca se havia tido nenhum trabalho relativo a isso no município. (grifos meus)

Davi: Na primeira edição em dois mil e oito eu fiquei sabendo do/da conferência através do próprio entrevistador né... o Rodrigo Crivelaro... que morava em Santos e trouxe para o nosso município a proposta de participarmos de uma conferência livre e depois ir para as outras conferências... a princípio era para montar a conferência livre... foi quando a gente se organizou com mais alguns jovens e com a ajuda de um amigo nosso que era vereador na época fomos até a cidade de Santos participar da conferência lá... e::: depois dessa conferência em Santos fomos/montamos essa conferência em Santa Bárbara... fomos para a estadual... fomos para a regional... até chegar na federal... (grifos meus)

Como observado em capítulo anterior, a realização da $1^{\text {a }}$ Conferência Municipal de Juventude remete ao sonho de um grupo de jovens amigos, ligados à Pastoral da Juventude (PJ) da Igreja Católica, que tinha motivações políticas e o desejo de pautar o debate das políticas públicas de juventude no município. Isso me faz pensar que, por detrás do conhecimento do que seria a conferência, existe também o desejo de revolução molecular definido por Guattari e Rolnik (1996, p.45) como "fatores de resistência consideráveis, processos de diferenciação permanente". 
Nosso objetivo não era criar na esfera municipal mais um dispositivo de controle. Éramos movidos por aspirações políticas para além das políticas públicas de juventude e pelo desejo de criar um espaço de debates das demandas juvenis e que ao mesmo tempo possibilitasse o encontro entre jovens de diferentes cantos da cidade, com necessidades parecidas. Acredito que as palavras de Dias (2002, p.53) refletem um pouco do nosso desejo e o que reverberou nossa ousadia ao propor a realização das conferências de juventude em Santa Bárbara d'Oeste.

Fez-se então um deslocamento do paradigma do progresso, que foi o termo nuclear e sustentador do projeto político da burguesia no século XIX, para as vivências das processualidades. Assumiu-se o risco de se lançar no movimento da vida e de sua criação no campo educativo.

Acredito que ao enveredarmos neste caminho de potência, não tínhamos clareza da dimensão do que estávamos propondo. Talvez muitas pessoas na cidade nem tenham conhecimento das conferências, porém creio que a sua realização, após quatro edições, tem contribuído no processo formativo e no modo de ver a cidade por parte daqueles jovens que delas participaram.

Ainda que as conferências possam ser problematizadas como dispositivos da biopolítica, vejo nas falas dos organizadores o desejo de promover a revolução molecular e não o controle e a fixação das identidades juvenis.

Esta origem é reforçada na fala do entrevistado Hugo, que, mesmo não fazendo parte deste grupo, remete à origem do evento ao grupo de amigos ligados à Pastoral da Juventude:

Hugo: Bom, da conferência em si eu fiquei sabendo pela divulgação, no
primeiro momento da conferência nacional e das etapas que vinham tendo e
da conferência específica em Santa Bárbara, no município, foi via prefeitura
na época no município porque estava já fazendo algumas conversas com um
representante da Secretaria de Governo porque existiria, naquele momento
estava existindo um interesse do governo municipal em constituir um órgão
de juventude no município e veio a demanda da Conferência Municipal de
Juventude, que na época foi apresentada, se eu não me engano pela Pastoral
da Juventude via câmara e tudo mais. (grifos meus)

Hugo assumiu com entusiasmo a participação e organização da $1^{\text {a }}$ Conferência no município, tendo papel de destaque também nas articulações que contribuíram para eleger representantes do município nas etapas subsequentes.

A partir deste contato dos jovens da Pastoral da Juventude e com protocolo para realização na prefeitura, formou-se a Comissão Organizadora, que teve a missão 
de tornar conhecido o evento, que em sua primeira edição ocorreu no mês de janeiro, tendo sua organização perpassado o Natal e festividades de Ano Novo.

Nesta primeira edição, a divulgação do evento foi feita pela mídia, a PJ e pelos amigos com potencial para divulgação. Nas demais edições, verifiquei que tanto a mídia, em especial o site da SNJ, quanto a prefeitura, a partir da Assessoria de Governo, e mais tarde o Conselho Municipal de Juventude, passam a ser as formas de propagação das conferências para as pessoas que compuseram as comissões organizadoras.

Quanto aos participantes, diante deste contexto, em sua organização, a primeira edição chegou ao conhecimento dos jovens que não eram membros da Comissão Organizadora Municipal (COM) através de grupos/ coletivos juvenis que participavam, ou através de convite de membros da comissão organizadora.

Dandara: Na verdade, naquele momento, eu participava de um grupo, aqui em Santa Bárbara, de adolescentes, que era o grupo IRSSA, Instrutores de Referência da Saúde Sexual e Saúde Reprodutiva, que desempenhava algumas ações voluntárias aqui. E, por conta desse grupo, ele trazer algumas temáticas que falavam a respeito de gênero, sexualidade e esses conflitos da juventude, nós fomos orientados a participar dessa atividade e era muito recente que eu tinha começado a participar desse grupo, se eu não me engano, as conferências começaram a acontecer em outubro... (grifos meus)

Enzo: Foi através da Pastoral da Juventude que eu participava. (grifos meus)

Na primeira edição, a Pastoral da Juventude (PJ) e o grupo IRSSA - Instrutores de Referência da Saúde Sexual e Reprodutiva - eram os grupos com maior número de participantes e se destacavam nos grupos de trabalho durante os debates e proposições.

Nas demais edições, a escola passa a ser um ambiente favorável à divulgação e convite para a participação dos jovens. A escola é apontada pela maioria dos jovens como o local em que ficou sabendo da realização da conferência.

Thaís: Porque você (risos), você foi na minha escola e convidou, aí eu convidei uma amiga e a gente acabou indo. Só que outras pessoas, tipo os meus amigos, tinham sido convidados pela crisma. (grifos meus)

Lara: Foi através de um amigo meu, que ele estudava na ETEC, foram falar sobre a conferência lá e ele falou pra mim e a gente acabou participando. (grifos meus)

Félix: através da escola né... que os... inclusive o vereador... eu não vou me lembrar o nome dele agora... e vocês também foram avisar-nos da... que haveria uma conferência aqui no centro sabe... mas eu não conhecia aqui ainda... (grifos meus) 
As falas de Lara e Thaís chamam atenção para outras duas formas de contato dos jovens com a Conferência: o tradicional boca a boca e o espaço religioso. Uma das formas de mobilização observada nas quatro edições da conferência em Santa Bárbara d'Oeste foi a divulgação entre os próprios jovens que, ao saberem, convidaram e divulgaram para outros amigos. Na fala de Thaís, ela chama à atenção que outros amigos ficaram sabendo através dos encontros de Crisma.

Isto ocorreu, em suma, devido ao enfraquecimento da Pastoral da Juventude (PJ), que deixou de possuir grupos em locais onde se concentravam os articuladores e organizadores da conferência. Diante disto, estes recorreram aos grupos de Crisma, outro espaço nas igrejas católicas onde os jovens podem ser encontrados, o que reforça a fala da entrevistada a seguir:

Melissa: ahn... através dos movimentos da igreja... na época eu era coordenadora de crisma... fui convidada por um dos membros da PJ da nossa éh... igreja... da nossa paróquia... (grifos meus)

Ao menos em Santa Bárbara d'Oeste, posso dizer que a escola, coletivos e grupos juvenis, sejam estes pastorais, coletivos culturais, ou ainda grupos e redes de amigos, bem como o espaço religioso, têm assumido papel de destaque como ambientes de divulgação das conferências. Isto mostra também que a divulgação da conferência no município tem se centrado nos espaços de participação tradicional, onde, em virtude dos agrupamentos, se tem maior facilidade de localizar os jovens, bem como de divulgar. Recordo que poucas foram as tentativas de divulgar em espaços não institucionalizados como as escolas e as igrejas. Lembro que, na primeira edição, fomos ao espaço de uma praça onde havia grande concentração de jovens, que ali estavam para "curtir a noite" ou "ficar de bobeira", como diziam em seu próprio linguajar. Porém, ao menos em minha memória, este foi o único momento em que fugimos dos espaços usuais como escolas, igrejas e a mídia.

Ressalto que a divulgação sempre se constituiu como uma dificuldade, pois, apesar de tratar-se de um evento convocado pela Prefeitura, o chamado corpo a corpo da divulgação era feito exclusivamente por integrantes da comissão organizadora municipal.

Outra problematização, relacionada à chegada da notícia de realização das conferências aos participantes, é que os mecanismos instituídos de promoção das políticas públicas de juventude destinados a toda a população jovem ainda possuem pouco alcance e reverberação entre a juventude. Penso que a SNJ e o CONJUVE 
ainda hoje apresentam limitações e são mencionadas, predominantemente, em narrativas de organizadores, cuja maioria são jovens que pertencem à militância, o que me permite pensar que estes espaços hoje se constituem como espaços destinados à juventude militante.

O quadro 13 exemplifica e diferencia como participantes e organizadores tiveram notícia da realização da conferência municipal de juventude em Santa Bárbara d'Oeste, tema abordado neste primeiro tópico de análise do território das conferências.

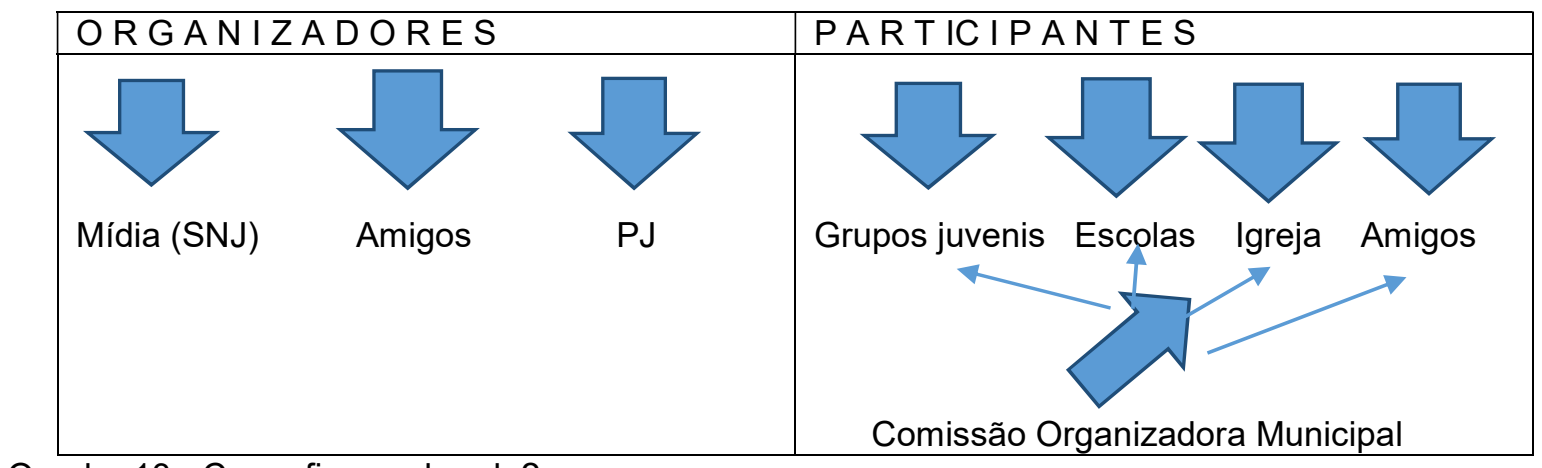

Quadro 13 - Como ficou sabendo?

A seguir, apresentarei possibilidades de análises dos significados e sentidos das conferências em Santa Bárbara d'Oeste.

\subsection{2 - Significados e sentidos das conferências}

Ao buscar cartografar os sentidos e significados da conferência para os participantes e organizadores, cartografei narrativas que denotavam sentidos, momentos marcantes e possíveis contribuições aos participantes.

A seguir apresento alguns sentidos cartografados:

\begin{tabular}{|ll|}
\hline A) & Conferência como marco das políticas públicas de juventude no município \\
\hline B) & Conferência como espaço de formação \\
\hline C) & Conferência como espaço de planejamento \\
\hline D) & Conferência como espaço de captura \\
\hline E) & Conferência como espaço do devir \\
\hline
\end{tabular}

Quadro 14 - Sentidos atribuídos à Conferência

A seguir, estes significados serão delineados com mais detalhes. 
A) Conferência como marco das políticas públicas de juventude no município: sentido de marco atribuído à conferência aparece predominantemente entre os envolvidos na organização do evento, mas também entre participantes da edição de 2008.

Durante as conversas com os entrevistados, as expressões "divisor de águas" e "marco" são utilizadas com o mesmo sentido. O que representa o reconhecimento de que as políticas públicas de juventude e os problemas presentes na realidade do jovem barbarense passam a ser tratados a partir da primeira edição em 2008. Desta forma, não existem memórias de outras situações, espaços, ou ações provocadas pelo poder público ou sociedade civil que denotem este contorno atribuído à conferência.

Pedro: Eu acredito que foi um ganho muito grande para a cidade visto que, como eu já falei antes que a cidade nunca tinha nada relativo a esse tema, foi a partir da primeira conferência municipal que o tema juventude realmente começou a entrar em um debate, tanto a nível legislativo como executivo, praticamente eu acredito que a partir da primeira conferência foi aí que começou as políticas públicas na cidade, tanto que tinha, na primeira conferência foram colocados vários anseios, em especial que foi colocado lá a criação de uma coordenadoria de juventude, realmente para estar tratando toda essa questão da juventude. (grifos meus)

Enzo: Eu acho que foi um marco em Santa Bárbara, até porque a gente nunca tinha é... tido um espaço desse aqui pra poder discutir esse tipo de situação, de coisa aqui na cidade, eu acho que foi uma coisa bem importante. (grifos meus)

Este contorno apresentado por Pedro pode ser encontrado também na fala dos organizadores Davi e Hugo e do participante Enzo. Outro aspecto que merece atenção nestas narrativas versa sobre a conjuntura nacional das políticas públicas de juventude. Nos documentos institucionais, o ano de 2003 é visto como o início das tratativas governamentais no Brasil no que tange às políticas públicas de juventude (PPJ), conforme observa Almeida (2009):

Com a criação da Comissão Especial de Políticas Públicas para a juventude, da Câmara dos Deputados, no primeiro semestre de 2003, a discussão sobre o tema das políticas públicas passou a fazer parte da agenda governamental do país. No segundo semestre deste mesmo ano, aconteceu a Semana Jovem que reuniu lideranças de várias organizações juvenis. A partir de então, a discussão sobre a elaboração de um Plano Nacional de Juventude ganhou força e espalhou-se pelo país através das conferências estaduais de juventude. Estas conferências foram uma espécie de preparação para uma grande Conferência Nacional de Juventude, convocada pela Comissão 
Especial da Câmara, que aconteceu em junho de 2004³. (ALMEIDA, 2009, p.36)

Porém, as iniciativas só reverberaram em Santa Bárbara d'Oeste a partir de 2008, com a realização da conferência municipal.

A conferência de juventude em Santa Bárbara d'Oeste pode ser entendida como um marco também porque foi nela que muitos jovens tiveram sua primeira experiência com o espaço de uma conferência.

Isso já reflete a potência e a importância da teimosia dos grupos juvenis envolvidos nestes processos, que, ao agregar outros jovens e interessados, conseguiram inserir em âmbito municipal o debate das políticas públicas de juventude, que até então nunca tinham sido alvo de leis que abrangessem exclusivamente a juventude. A conferência como marco reverbera não apenas em um evento, mas em todo um debate que foi desencadeado pós-conferência, incluindo a juventude na pauta do poder público.

B) Conferência como espaço de formação: Para muitos jovens participantes, a conferência é vista como um espaço de formação. Não apenas no sentido de educação para a cidadania, mas também como um espaço formativo que pode ressoar em outras possibilidades de formação, seja na visão acerca do jovem e da juventude, formação para futura inserção no mercado de trabalho, formação no reconhecimento da realidade local.

Dandara: Na verdade, para mim, foi, realmente, esse despertar desse interesse. Ali, eu comecei a ver que existiam grupos que trabalhavam com políticas públicas, não tinha ideia do que que era essa dimensão. Então, foi algo muito primitivo, se é que eu posso usar essa palavra, de te dizer, assim, que, mas, ao mesmo tempo, foi uma base, porque foi ali que eu comecei a entender como é que funcionariam aqueles processos anteriores. Quando eu estava na conferência estadual, que eu comecei a entender algumas coisas que a gente tinha passado. Por que que precisava, da onde tinha surgido aquelas demandas, né? Porque, ao mesmo tempo, eu acredito que para quem não tem a dimensão do que é uma conferência de juventude, estar ali é muito abstrato, porque você fica pensando: "da onde que esse povo tirou essas coisas?". (grifos meus)

Amanda: Então assim... eu encarei a conferência desde o momento em que nós conversamos em que eu optei por estar participando... estar envolvida em um processo... desde o início... eu encarei a conferência ahn... como um encontro de jovens com o intuito de ter um real conhecimento de questões

83 Vale lembrar que este evento realizado em 2004 foi convocado pela Câmara dos Deputados e, devido aos contornos do evento, não é considerado a $1^{\text {a }}$ Conferência Nacional de Juventude, mas sim um Seminário realizado para debater as políticas de juventude. 
ahn... de questões locais.. mas, mas e um real conhecimento de tudo... porque lá logo depois nós dividimos e cada um tinha um tema específico para estar trabalhando, então sempre encarei muito mais como isso... ahn: então agora nós queremos ter um conhecimento real daquilo que é a NOSSA história... história de Santa Bárbara... uma coisa que ainda não se tem contada em livros... que a gente não encontra em biblioteca... encarei muito mais como isso... uhn:.: então nós vamos criar debates... nós vamos entender o que as pessoas pensam DA CIDADE... então não é uma ordem que veio de cima... não é uma opinião de uma lei federal... enfim não... é uma coisa pessoal... dentro da nossa realidade de Santa Bárbara... quais são os reais problemas que eu tenho? então não estou muito preocupada com as favelas que existem no Rio de Janeiro... no morro... ou com as favelas que se tem em São Paulo dentro dos grandes centros... eu estou preocupada ahn::: com as invasões que a gente tem aqui no Zumbi... que está de frente para uma escola técnica... como é que a gente vai conseguir éh::: conduzir isso?... para que os alunos não achem que vão ser assaltados... porque ali existem pessoas que tem moral... que tem/que precisam... que estou buscando uma melhoria de vida... como é que eu vou equacionar isso... isso é regional... EU encarei desde o início a questão aí da/desse encontro... desse trabalho... para poder buscar exatamente isso. (grifos meus)

Observo este contorno de espaço de formação quando nas narrativas produzidas aparece o olhar de contato com a política para além do espaço escolar. Como apresentado por Dias (2002, p.71), "a prática da discussão é outro campo repleto de possibilidades. Aqui, demarcamos nas experiências os aspectos potenciais e interpretamos as marcas que expressam a vitalidade". Esta política, e esta vitalidade, construída a partir da experiência e do contato com o outro, está no ouvir o que o outro diz, questionar as afirmativas, debater caminhos, possibilidades e escolhas, bem como conviver com as diferenças.

Davi: Aprender a respeitar as diversidades da juventude... então sou um jovem... era um jovem na época... hoje já sou um adulto... mas porém católico... apostólico... romano... (sorriu)... ou seja... criado dentro de uma doutrina que a partir do momento que se deu conta que era militante da juventude tinha que se despir de todos os preconceitos... de todas as relações... que a minha luta... a minha bandeira... é a juventude... e não a religião... e... acredito que eu cresci muito com isso... tanto que hoje eu consigo... dentro do conselho tutelar... dentro do/da minha formação para com os meus filhos... colocar que a gente tem que aceitar as pessoas da maneira que elas são e respeitar pelo que elas são... e não pelas opções que elas fazem...(grifos meus).

A fala de Davi sinaliza que a participação nas conferências é um processo de formação que reverbera para além do espaço das conferências.

Ao propor a realização da conferência, ainda que observada de fora dos espaços da educação maior, como a escola, foi possível contribuir com a formação de várias pessoas. A partir das narrativas, entrevistados com inserção no espaço escolar, como professor ou estudante, mostram a conferência como espaço formativo, 
ocupando lacunas deixadas pela escola, permitindo aos participantes discutir experiências de vida, a realidade local e assuntos que intrigam e inquietam os jovens.

Mas assumindo a conferência como um espaço de educação menor na formação dos jovens, seria ela responsável por abranger apenas temas referentes à realidade local? Ou assuntos que perpassam a realidade dos jovens? Para muitos participantes não, considerando a amplitude dos temas que são abordados.

\begin{abstract}
Lara: Foi um momento que eu pude expor minhas opiniões sobre os assuntos tratados nela, que eu fiquei com o tema eu acho de... de cultura mesmo e foi um momento que a gente pôde expor nossa opinião e ser ouvido e também ser debatido pra gente ver o porque não acontece tantas coisas....(grifos meus)

Tom: É um momento, um ponto, um evento de informação, busca, troca de experiências, interação, eu acho interessante colocar isso daí, né? A interação entre os jovens e a troca de experiências pra falar a mesma linguagem, vamo colocar assim (grifos meus).
\end{abstract}

Para os participantes, essa formação se configura a partir da interação entre eles. No espaço da conferência, não existe alguém na figura do professor da escola tradicional conteudista. Nas duas primeiras edições, cada grupo de trabalho (GT) possuía um facilitador com a função de provocar o debate sobre o tema. Nas duas últimas, não houve grupo de trabalho, todos permaneceram juntos e debateram sobre todos os temas da conferência. Havia apenas alguém fazendo o indicativo da sequência dos temas, permitindo maior horizontalidade nas discussões.

A democracia ganhou no espaço das conferências o pensado por Dias (2002, p. 62): "A democracia torna-se acontecimento nas experiências. Por isso vamos olhar para as experiências como o lugar mais indicado para descobrir as trilhas de construção de uma cidade onde a vida possa ser melhor".

Neste movimento de construção, a partir da experiência e do convívio, observo a conferência como um espaço de formação política, formação para o diálogo e oratória, tendo em vista a necessidade de convencer outras pessoas para que suas propostas e ideias entrem como demandas prioritárias.

C) Conferência como espaço de planejamento das políticas públicas: Foi possível observar o espaço das conferências percebido como espaço de diálogo entre poder público e sociedade civil para o planejamento, disparado na proposição de políticas públicas. Este contorno, destacado entre os participantes e organizadores, assemelha-se à concepção prevista no SNPS. 
Caio: É uma... foi e é uma constante busca pela demanda do jovem em relação ao que ele espera de cidade na visão dele né... o que é pra ele uma cidade adequada no aspecto cultural... social... econômico... mas além disso é uma busca do conselho como estrutura de criar documentos que materializem esses anseios do jovem né... e que eles se vertam no futuro em políticas públicas né... acho que essa é a maior... éh razão de ser das conferências. (grifos meus)

Enzo: Então, porque, aquela coisa, a gente discute isso na conferência em si, mas se não tem um acompanhamento do que foi discutido, isso não é passado pra frente, pro responsável, pra se tomar essa providência, então, fica só no papel. (grifos meus)

Amanda: Por isso a conferência eu acho... eu acho um ponto... eu acho uma grande ferramenta para poder desenvolver essas políticas...(grifos meus)

Caio: Ahhh... a palavra aberta ao jovem... com certeza... como a gente falou... se você né/se existem jovens que já tem esse sentimento aí éh::: internalizado de questionar... de querer debater e de querer colocar sua opinião... é né... formalizada num documento... o espaço dado a eles né/nos diferentes eixos que é a palavra a eles é o exercício máximo do que ao meu ver é a conferência mesmo né...que é de deixar ele mesmo se expressar a sua maneira com liberdade éh::.... e fazer daquela opinião dele algo que possa de fato acontecer em nível de política pública... então éh::: o mais importante ao meu ver mesmo é exatamente isso. (grifos meus)

A conferência pode cumprir o sentido de sua proposição, através da escuta e diálogo entre poder público e sociedade civil para o planejamento das políticas públicas, a partir das demandas apresentadas pela sociedade.

As demandas da realidade cumprem a função de orientar o planejamento. Elas estão presentes o tempo todo, às emboladas, confusas, sem muita coerência entre si e entre elas e os planos. Com isso, experimenta-se um momento de articulação entre as emoções trazidas por estas demandas e as escolhas racionais, como tentativas de vincular os projetos políticos às necessidades circunstancias. É como se pudéssemos dizer que o calor da hora aquece os planos. (DIAS, 2002, p.73)

A grande problemática que encontro, neste sentido atribuído à conferência, responsável por frustrar participantes e organizadores, é a não efetivação desta proposta de diálogo com a consolidação de políticas públicas.

Para o sentido de conferência como espaço de planejamento reverberar de forma mais intensa, é preciso que os responsáveis por convocá-la se atentem ao que é apresentado e debatido pelos participantes. É preciso que ela se efetive, enquanto espaço de diálogo, subentendendo que ambas as partes estejam dispostas a ouvir. 
D) Conferência como espaço de captura:

Dandara: $E$ aí, assim, eu acho que entra muito no seu trabalho que é essa questão. Eu, até aquele momento da conferência, era uma jovem neutra, vamos se dizer assim. Era uma adolescente neutra, não tinha ideia, não conhecia, não entendia bulhufas do que que eram essas questões de juventudes, um movimento de juventude. Quando eu entrei lá dentro, não necessariamente aquelas discussões me representavam, porque eu não entendia, falava: "nossa, mas por que que estão falando sobre isso?". Então, isso reflete, também, um olhar de uma juventude politizada, de uma juventude que já tem uma dimensão política diferente e, aí, é uma questão crítica, também, que a gente começa a pensar até que ponto essa juventude politizada ela representa a grande massa.

Utilizo a expressão captura aqui para designar algo que se opõe ao devir. Ou seja, enquanto o devir é algo que implica "nunca imitar, nem fazer como, nem se conformar a um modelo, seja de justiça ou de verdade" (DELEUZE; PARNET, 1998, p.6), a captura é o imitar, o repetir um modelo.

Neste sentido, pensar as conferências como espaço de captura é pensar que existe um modelo de participação, e este modelo é produzido por dispositivos que o configuram como verdade.

Por isso, ao analisar a fala de Dandara, problematizo: Quem pode assumir o rótulo de neutro, e quem pode assumir o rótulo de politizado? Seria o jovem politizado o jovem capturado pelos discursos hegemônicos, que em determinados momentos se sobressai e nem sempre replicando o discurso da maioria dos jovens? Seria o jovem com facilidade para influenciar outros? Teriam os jovens politizados mais força dentro do espaço das conferências do que os jovens chamados por Dandara de neutros? Outro questionamento que levanto é quanto à possibilidade do discurso apontado como neutro resistir aos discursos dos jovens politizados.

Observo que neste espaço o jovem politizado é subjetivado a partir de múltiplos dispositivos como apresentam Guattari e Rolnik (1996) ${ }^{84}$.

Trata-se da produção de uma imagem de referência, neste caso do jovem politizado, que aqui dispara questões como: "O que é ser politizado?"; "Como participar?"; "Como falar e expor idéias?". Percebo aqui uma possibilidade de reflexão que este espaço de formação pode estar engendrando como uma formação para ser politizado. Logo o participar e adquirir vivência e experiência neste espaço pode transformar o jovem em um jovem não neutro, ou seja, maquinado e subjetivado como politizado. Quando se narra que alguns são politizados, em detrimento de outros que

84 Vide citação dos autores presente na página 33. 
não o são, está se construindo uma verdade sobre o que é ser politizado, dentro deste modelo binário.

Trago de minhas memórias que este era um desejo nosso enquanto organizadores, de transformar em militantes e politizados os jovens dos grupos de que participávamos e os jovens que vinham ao espaço da conferência. Víamos nesta possibilidade uma forma de reforçar nossa potencialidade de jovens a fim de pressionar o poder público para que as demandas juvenis fossem atendidas por ele.

Este desejo, porém, sempre esbarrou em outros desejos dos jovens que rejeitavam esta captura, e no olhar do poder público desqualificando o evento, ao analisar exclusivamente a quantidade de participantes, secundarizando a qualidade do debate apresentado.

Ao deixar de ser neutro, conforme exposto por Dandara, penso que ao ser capturado se pode, ainda que de forma momentânea e não permanente, abandonar o devir revolucionário de não ter um modelo, não ter de onde se parte, nem aonde se chega, tampouco uma verdade (DELEUZE; PARNET, 1998).

Esta captura também aparece quando as conferências e sua própria nomenclatura são associadas ao mundo adulto, como mencionado por Théo.

Théo: Acho assim, para os jovens isso aí não é uma coisa, tipo assim... é uma coisa interessante, mas não é uma coisa legal, entendeu? Então acho que devia ser uma coisa mais... uma coisa que mais atraísse o jovem, mais coisa jovem, sabe? Não uma coisa mais... não quero falar adulto, mais uma coisa mais... sabe? Para adolescente, assim. (grifos meus)

A fala de Théo destaca algo que mostra a conferência vista como do mundo adulto. Estaria esta característica relacionada à linguagem do adulto, que é em parte a linguagem da conferência? Sendo que aqui o mundo do adulto é visto por Théo como algo chato. Logo a captura estaria em adotar o comportamento adulto no espaço da conferência, associando também a juventude vista como politizada apresentada nas falas de Dandara.

Os perigos desta captura estão nos processos que impedem as individuações, quando as máquinas capitalísticas passam a produzir indivíduos em série, e servem para "assegurar um controle cada vez mais despótico sobre os sistemas de produção e de vida social" (GUATTARI, ROLNIK, 1996, p. 39).

Enquanto organizadores, o receio da conferência ser vista como algo chato pelos jovens nos incomodava muito, bem como o olhar reforçado de política como algo chato e que desperta pouco interesse da população. Então, enquanto 
divulgávamos, muitas vezes secundarizamos este olhar, buscando reforçar aos jovens as potencialidades da conferência, numerosas vezes escondendo as capturas presentes neste espaço.

Isto, porém, leva a observar que os jovens assim como são fixados também fixam os adultos, o que pode estar associado à dificuldade de assumir a vida adulta. Será que ser adulto pode se resumir apenas a falar e fazer o que é chato?

E) Conferência como espaço do devir: Porém, os participantes das conferências também estão sempre construindo outra forma de viver e de sentir este espaço de participação. Ao possibilitar viver este espaço de outra forma, eles transformam a conferência também em espaço do desejar, fugindo dos sentidos e cronogramas a ele atribuído. Acabam por provocar uma desterritorialização dos sentidos da conferência, transformando-a em espaço de potência, espaço de devir.

Isso é perceptível nas conferências por meio das narrativas que a engendram como um espaço de prática de lazer e de tempo livre, ou como possibilidade de encontro e articulação para a produção do novo que se concretiza a partir dos contatos e amizades que são estabelecidas, a partir do encontro com o outro realizado nas conferências.

Dandara: Eu acredito que, primeiro, porque era um espaço de possibilidade. Levantava-se alguns temas e algumas questões que outros espaços não levantavam. Então, supria algumas coisas que, por exemplo, a escola não trazia. A gente queria falar sobre alguns conflitos que nós vivíamos e que a escola não comportava, até porque a visão que eu tinha era que, partindo do meu ponto de vista, supria essa característica. (grifos meus)

Hugo: Eu acho que é um crescimento pessoal de conhecimento, de experiências vividas, profissional também no sentido de você melhorar o que você sabe fazer de organização, de lidar com pessoas, de ser, toda a questão que envolve a questão da liderança, então para mim pessoalmente foi um processo muito enriquecedor tanto a conferência quanto o que ela acabou gerando, que foi a experiência de estar seis meses, um pouco mais aí, oito meses e pouco a frente representando um governo em uma política de juventude. Então, eu acho que esse talvez foi um ganho muito importante não diretamente está ligado à conferência, mas com certeza ela impulsionou porque mexeu com o governo atual de realmente se mobilizar e ter uma atitude diferente para com a questão da juventude. (grifos meus)

Elis: Sim, muita, principalmente como cidadã de Santa Bárbara d'Oeste, que como eu disse, eu era daqui e não conhecia ninguém que se movimentava aqui e eu por estar inserida nesse meio, tenho um grande interesse nesse meio, foi ótimo pra mim fazer várias amizades, vários contatos, o Miguel é uma pessoa também que tá vindo pro coletivo agora, eu fiz o convite, conheci ele na conferência, tem anseios parecidos, tem ideias parecidas. Então pra mim como pessoa, acho que ajudou muito de conhecer quem é o pessoal da minha cidade, quem é a juventude da minha cidade, o que eles fazem, o que 
eles querem, isso pra mim e pro coletivo ser uma ótima fonte de contato pra evento, porque, por mais que a gente seja um coletivo cultural, a gente precisa muito do apoio da prefeitura e apoios pra que tudo aconteça em praça pública, de forma transparente pra população local, então eu acho que mudou muito, muito mesmo, tem um leque maior quando eu vou falar de participar de alguma coisa ou de movimentar alguma coisa, criar alguma coisa ou simplesmente de discutir alguma coisa como pessoa, fora do coletivo, acho que abriu bastante. (grifos meus)

Tais narrativas são construídas em especial quando é perguntado aos participantes sobre o que houve de mais importante. Na fala de Elis, é observado o objetivo de participar para ampliar a rede de contatos com o poder público, para encaminhar diretamente suas pautas, ou mesmo para conhecer outras pessoas, que possuam desejos semelhantes. Porém, organizadores e participantes concordam, quando afirmam que as possibilidades trazidas pela realização da conferência são o ponto mais importante.

No caso dos espaços institucionalizados, a conferência foi devir ao possibilitar a organização do primeiro conselho municipal de juventude, cujas cadeiras foram preenchidas com participantes das duas primeiras conferências, que diante do entusiasmo pelo produzido continuaram participando e construindo potencialidades a partir do conselho.

A conferência é aqui vista como espaço de possibilidades de propor algo a ser construído para a juventude no município, possibilidades de descobertas e aprendizagens, e até mesmo de envolvimento dos jovens e sua participação.

Ao observarmos o processo de construção democrática da cidade, nesta
forma do acontecimento, vemos as pessoas ampliando os seus campos de
possibilidades. Isto é, o aprendizado de outro exercício do poder não se
restringe às autoridades políticas coordenadoras dos programas de
participação, pois muita gente começa a se apropriar de conhecimentos e a
desenvolver habilidades no campo das relações políticas tecidas na e sobre
a cidade. O Estado e a sociedade civil se reinventam nas relações que
estabelecem entre si ao construírem uma cidade para todos. (DIAS, 2002,
p.37)

Dandara: Ah, não, trouxeram várias coisas, assim. Eu acho que eu ainda volto para o meu discurso anterior, que é a questão da possibilidade. (grifos meus)

Vejo que quando se está na conferência, se consegue potencializar este espaço possibilitando formação, acerca da realidade do município, do cenário juvenil na cidade, bem como sobre o que os jovens pensam e o que querem falar.

Outros participantes mencionam como o momento mais importante os shows e as atividades culturais que aconteceram durante o evento. Alguns participantes, por 
exemplo, não entram nas salas onde ocorrem os eixos temáticos e significam o espaço como possibilidade de ter um domingo ou um sábado diferente, em uma cidade com poucas possibilidades de lazer e entretenimento. A conferência surge como um espaço de lazer e de possibilidade de encontrar outros, para além dos limites de bairros e escolas.

A entrevistada Thaís destacou, em uma narrativa apresentada, a busca por um momento de lazer ao ir à conferência e a conferência como forma de atrair outros jovens, o que também é propagando pela divulgação do evento, tendo em vista que no cartaz de divulgação das etapas de 2008, 2011 e 2015 o chamariz cultural é apresentado pela organização para atrair os jovens às atividades. Ainda que não obrigados a estarem presentes, eles utilizavam o espaço para ver as atividades culturais, conhecer locais que no cotidiano deles não Ihes são familiares, brincar com amigos, e até mesmo não fazer nada, ou conversar sobre coisas e assuntos que também não são postos na ordem dos trabalhos da conferência.

Ao tentar cartografar o momento mais importante da conferência, a visão dos organizadores traz um aspecto diferente ao destacar a concretização de um sonho ou ainda o acontecer do evento. Isto se apresenta pela vivência na organização e planejamento para que a atividade acontecesse.

Davi: A mobilização que a gente conseguiu fazer na cidade... com poucos recursos.. com mínimos apoios... fazer acontecer todas essas conferências... éh::: com duas ou três pessoas lutando... no máximo aí dez pessoas... vamos colocar aí... engajadas para fazer acontecer... para fazer o nome da cidade que até então... antes do cenário de dois mil e oito não era conhecida no cenário nacional... e hoje nós temos um representante de juventude fazendo parte da conferência a nível nacional para organização... isso para mim me deixa muito satisfeito que meus sonhos não morreram...(grifos meus).

Miguel: $O$ momento mais importante... eu acho que foi justamente a concretização de tudo o que a gente vinha construindo, não é?

Narrativas com tal sentido também apareceram em falas dos organizadores Pedro e Hugo, e produzem este sentido pelo fato de os organizadores sentirem a grandeza de terem organizando algo com caráter municipal. O acontecer da conferência para nós era a concretização de um sonho, era efetivar o sentimento de que éramos capazes de fazer aquilo acontecer.

Para Miguel, o devir está também em vislumbrar uma nova forma de fazer política: 
Miguel: Ela para mim... realmente mudou o meu conceito de política e realmente me mostrou o que realmente eu posso fazer pelo meu município. E também me abriu portas, para eu expandir o meu movimento.

Sua narrativa é produzida a partir de experiência do despertar para a articulação do movimento LGBT na cidade, articulação até então pouco visibilizada.

Ao observar estes cinco possíveis sentidos e possibilidades de contorno dado ao espaço das conferências, vislumbro nesta atividade a perspectiva de revolução molecular apresentada por Guattari e Rolnik, ao identificarem todos os níveis os quais a revolução molecular perpassa sincronicamente.

A ideia de revolução molecular diz respeito sincronicamente a todos os níveis:
infrapessoais (o que está em jogo no sonho, na criação, etc.); pessoais (por
exemplo, as relações de autodominação, aquilo que os psicanalistas chamam
de Superego); e interpessoais (a invenção de novas formas de sociabilidade
na vida doméstica, amorosa, profissional na relação com a vizinhança, com
a escola, etc.). (GUATTARI, ROLNIK, 1996, p. 46, grifos meus)

Vislumbro o nível infrapessoal, quando menciono a conferência enquanto devir; pessoais, quando a conferência é posta como espaço de captura; e o nível interpessoal estaria na conferência como espaço de planejamento, marco das políticas públicas e espaço de formação.

Mesmo no espaço das possibilidades de sentidos como captura, planejamento, formação e marco, é possível identificar o devir que se faz presente quando os metabolismos produzidos nestes espaços produzem a novidade. A realização da conferência, por exemplo, em 2008, traz esta novidade, pois tem como estopim um desejo. Este desejo produziu devires ao escapar das capturas e ressignificar as possibilidades e potencialidades engendradas neste espaço.

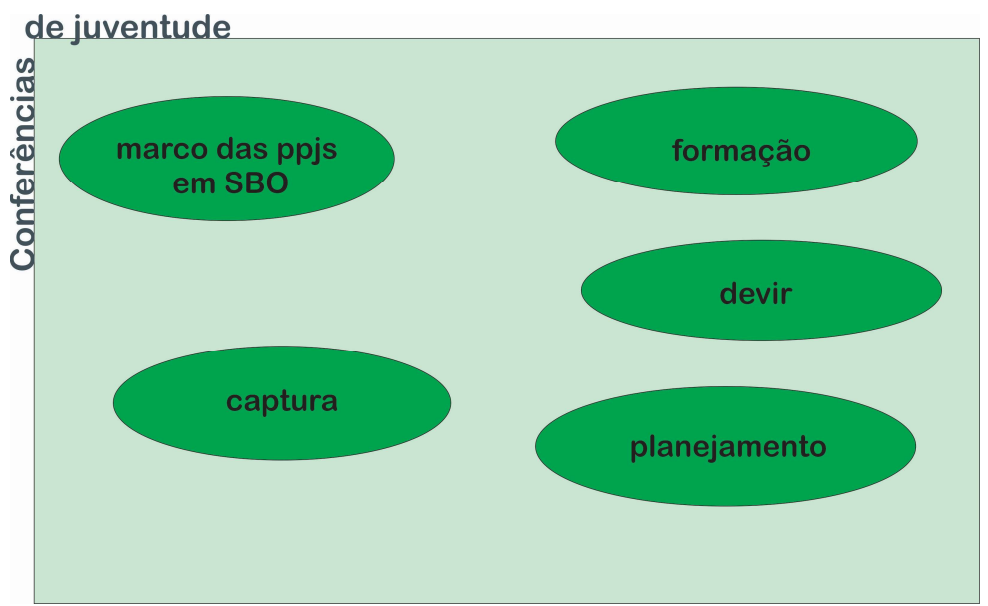

Figura 16 - Sentidos atribuídos às Conferências de juventude 
A figura 16 sintetiza os sentidos observados, a partir das análises das entrevistas aos participantes das conferências que foram apresentados neste tópico de análise. A seguir, passei à análise das dificuldades e desafios elencados ao longo de quatro edições de conferências municipais.

\subsection{3 - $\quad$ Dificuldades e desafios}

Encerro o território das conferências, analisando as dificuldades e desafios a serem superados por este espaço. Nesta tentativa, junto aos companheiros de voos e pousos, cartografei quatro dificuldades e desafios a serem superados pelas conferências de juventude em Santa Bárbara d’Oeste: A) Pequeno número de participantes; B) Apoio do poder público, escolas e igrejas; C) Dia escolhido para realização do evento; D) Divulgação dos encaminhamentos e resultados.

A) Pequeno número de participantes: O considerado pelos entrevistados como pequeno número de participantes é atribuído aos problemas com a divulgação do evento.

Os entrevistados, tanto organizadores quanto participantes, referem dificuldades relacionadas à divulgação. Mesmo nesta convergência é possível encontrar olhares diferentes, visto que os organizadores relatam problemas financeiros e falta de apoio da prefeitura para divulgar o evento. Por outro lado, os participantes (Elis e Lara) questionam as estratégias de divulgação, e as técnicas adotadas para divulgar o evento.

Elis: E agora? Eu vejo por mim, como eu disse, eu acho que, eu só fiquei sabendo mesmo da conferência pelo Marcelo que participa daqui, não chegou pra mim, então eu acho, a divulgação, colocar uma divulgação forte, principalmente em mídia social, principalmente, e fazer panfletagem em porta de escola e coisa do tipo, nem panfletagem que seja, conseguir um espaço na escola, que eu acho que foi o que vocês fizeram nas escolas lá do Cruzeiro, que como eu não estudo mais, eu acho que também seja uma alternativa e ir atrás também desses movimentos, porque se a prefeitura sabe, se o poder público sabe que tem movimentos estudantis, que tem movimento dos jovens, que já participam, que se movimentam, simplesmente fazer alguma parceria com esses movimentos, criar, divulgar pros jovens ou vai fazer um evento separado, divulgar, entrar mesmo em contato com quem tá se movimentando e repassar isso, acho que é o mais importante. Eu vi algumas coisas depois, que eu fui ver, a página do Conselho de Juventude de Santa Bárbara, que eu fui ver depois, e vi realmente algumas postagens 
de algumas coisas que fizeram, enquanto eu não curti a página pra mim não chegou, talvez trabalhar um pouco mais nisso aí, pra que mesmo quem não saiba da existência da página, facebook tem algumas coisas de divulgação com coisas de 7 reais por mês, você consegue chegar pra região inteira, principalmente eles têm alguns mecanismos lá que volta, voltado pra idade, voltado pra região e é coisa básica assim, de 7 a 20 reais no mês, você faz um estrago enorme em divulgação, talvez seja uma boa. (grifos meus)

Lara: eu não vi nada nesse estilo, eu acho que faltou mesmo foi a questão da divulgação, porque...tinha uns cartazes espalhados pela escola, só que as pessoas não tinham muito interesse em ver aquele cartaz, tinha cartaz espalhado na igreja, na escola e em outros lugares, mas os jovens não tinham interesse em ver, eu acho que faltou mesmo mais divulgação. 0 jovem ele é bem mais atraído por questões on line, facebook, rede social, tipo cartaz, por exemplo, na escola tem um monte de cartaz espalhado e nesses cartazes são coisas importantes, tipo reuniões que tem que ter com os representantes de sala, tudo isso, só que as pessoas acabam não lendo, pensando que não é nada importante. (grifos meus)

Nestas narrativas, o problema quanto à divulgação estaria nas estratégias adotadas pela organização. Sugerem, inclusive, possibilidades de estratégias para superar este desafio, entre as quais mencionam maior divulgação por redes sociais, reuniões em escolas com representantes de classe potencializando o tradicional boca a boca.

Esta afirmação faz sentido, quando associada à pergunta "como você ficou sabendo", e temos respostas de vários participantes informando que a divulgação se deu através de amigos, em espaços que costumam frequentar.

Contudo, os organizadores relatam que todas as estratégias possíveis foram adotadas, como o uso da internet através das redes sociais. Para eles o grande problema da divulgação estaria na falta de apoio da prefeitura, como observei nas falas que apresento a seguir.

Caio: Bom... não é um empecilho... mas é algo que acaba diminuindo a presença... é a dificuldade que a gente tem da divulgação dos nossos eventos né... não só da conferência mas do/das ações do conselho e as vezes da própria prefeitura ela é... cega em relação a isso que não há uma divulgação específica dessas ações né... éh... a conferência assim como a nossa semana e tudo mais... a gente já está careca de saber disso... são eventos municipais em que conselheiros são responsáveis quase que exclusivamente pela criação e divulgação do evento... então a:::/ o maior empecilho que a gente tem hoje em termos de participação efetiva do jovem é levar a ele o conhecimento que ele tem espaço pra isso éh. (grifos meus)

Davi: Na minha opinião éh... as autoridades que compõem... né... que estão aí nas cidades... o prefeito... os diretores de escolas... os secretários... éh... vestirem a camisa da conferência... e saber que ali é um espaço que eles podem tirar as ideias e fazerem sair do papel para que a nossa juventude... hoje a gente está enfrentando no nosso município um problema de espaço para os nossos jovens... nós não temos espaços adequados para eles... ((sorriu)) todas... todas as dificuldades possível... desde ahn... um simples éh... panfleto para poder fazer a divulgação... ahn... as dificuldades para 
conseguir contratar alguma pessoa para poder fazer algum show... dificuldades até mesmo para marcar uma reunião... com um secretário ou com o próprio prefeito... éh... de infraestrutura... tudo não pode... não dá... não tenho dinheiro... não é... dificuldade também em arrumar pessoas... alguns jovens para se comprometerem mais com a causa... porque muitos estão em horário de est/estavam estudando... estão trabalhando... e não têm tempo né... aos finais de semana também acaba que sendo corrido... foi muito difícil... muito mesmo... (grifos meus)

Pedro: Eu acho que nessa questão mesmo um pouco mais de engajamento do poder público, tanto na questão de divulgação, e na questão de um atrativo melhor para que o jovem pudesse estar vindo para a conferência... (grifos meus)

É, então, consensual que existem dificuldades de divulgação que acabam por produzir o "baixo" número de participantes. O que muda são os responsáveis pela má divulgação: ora é a comissão organizadora, por não adotar estratégias que reverberem de forma mais intensa, ora é o poder público, por não possibilitar a utilização destas estratégias.

Outro ponto que resultou em pequeno número de participantes é o sentido e significado atribuídos às conferências por alguns jovens. Para Hugo e Miguel, que foram membros da comissão organizadora em 2008 e 2015 respectivamente, o problema não estaria apenas na divulgação, mas no próprio despertar do jovem para o espaço e para o tema:

Hugo: É, eu acho que assim, a gente sempre acaba voltando, não sei, eu sempre tenho essa sensação da estratégia de divulgação, de como envolver mais pessoas, mas ao mesmo tempo a gente também, naquele momento e não é tão diferente da realidade de hoje, você ter o jovem motivado em participar ou se engajar em alguma coisa não é tão simples assim, então você pode fazer uma excelente campanha de divulgação, essa divulgação vai chegar até o jovem, mas o ponto de despertar nele o interesse em participar e se envolver, eu acho que essa é a grande resposta que a gente tem que buscar hoje, como realmente trazer o jovem para a participação. Embora muita gente fala "Aí, eu gostaria de participar", mas quando a oportunidade aparece nem sempre ele assume essa papel. (grifos meus)

Miguel: É, eu acho que a forma que a gente abordou alguns jovens para tentar atraí-los foi bem interessante, a divulgação, a gente bombou a divulgação para essa conferência, mas eu acho que falta um pouco o despertar desses jovens, não é? Eu acho que muitos desses jovens ainda estão acomodados. Ah, enquanto não estiver me afetando, para mim tudo bem. Mas essa visão a gente tem que mudar um pouquinho, não é? E é o que muitos dos jovens têm. $E$ às vezes você vai falar assim, "ah, vou num sábado de manhã para passar o dia inteiro lá na conferência, vou perder meu dia para falar de política", e muita gente não gosta de falar nesse assunto. (grifos meus) 
Essa fala é corroborada por jovens participantes e até mesmo por Caio, organizador da conferência em 2014. Para Caio o problema está em o jovem saber o que é a conferência, entender o que é e para que serve este espaço.

Caio: $\underline{O}$ maior empecilho que a gente tem hoje em termos de participação efetiva do jovem é levar a ele o conhecimento que ele tem espaço pra isso éh::: por mais paradoxal que seja é esse é o nosso maior dilema né... em segundo lugar a gente tem éh::: acho que é a dificuldade do jovem em talvez por não/há tanto tempo não ter o conhecimento de que ele possui espaço pra isso... de quando ele se dirige à conferência pra expressar sua opinião né... acho que esse é a segunda maior dificuldade que a gente tem... que o jovem reconheça a conferência como um espaço efetivo de participação dele sem que a gente precise instigá-lo a dar sua opinião e tudo mais né...(grifos meus)

Jovens participantes destacam também estes empecilhos, agregando ao exposto pelos organizadores a ideia de que a palavra conferência traz um sentido que afasta o jovem, por muitas vezes estar diretamente associada a algo chato ou do mundo dos adultos:

Lara: Também por questão do jovem olhar aquilo, tipo, fala, conferência, eles verem conferência como algo chato, eles nunca veem como algo, tipo, legal. Algo... muito formal, que só vai falar coisa séria e que só vai... ir adultos mesmo, não vão muitos jovens, acho que é basicamente isso. (grifos meus)

Théo: Acho assim, para os jovens isso aí não é uma coisa, tipo assim... é uma coisa interessante, mas não é uma coisa legal, entendeu. (grifos meus)

Já para Amanda, o cenário político atual reverbera nos sentidos atribuídos à conferência, transformando-a em algo visto pelos participantes jovens como algo chato, do mundo dos adultos. Conferência é termo que envolve política, presença de jovens militantes, e isso faz com que o espaço de conferência seja compreendido como algo não prazeroso.

Amanda: A descrença... a descrença política... eu acho que as pessoas encaram assim... bom a conferência da juventude... isso deve estar ligado à política... isso deve estar ligado ao prefeito... deve estar ligado a não sei o que... e.:.: como normalmente as pessoas que lideram isso... elas têm uma opinião política muito forte... porque se você é crítico... você acaba tendo opiniões políticas muito fortes... então sempre eles acham que isso está ligado a algum partido... aí fulano quer se reeleger... é que não sei quem está querendo se mostrar... com certeza vai querer::: se candidatar na próxima eleição... e cria-se isso... então acho que a descrença política é o que... é o fator chave aí que acaba distanciando. (grifos meus)

Diante do exposto pelos participantes, penso que existem, sim, erros de estratégia que impedem a organização e a conferência de chegarem aos jovens que não estão em espaços instituídos de participação. O foco da divulgação está muito 
concentrado em escolas e igrejas, que são os espaços onde os organizadores estão inseridos e onde eles vislumbram facilidades na divulgação.

Sobre a falta de apoio da prefeitura, talvez o engajamento não aconteça fora das mídias, como, jornais, sites e rádio, em virtude de os governantes não perceberem nestes espaços a mesma importância e sentidos atribuídos pelas pessoas que compõem a organização.

$\mathrm{Na}$ verdade, trata-se de um reflexo do cenário nacional. Conforme apresentado em pesquisa da SNJ em 2014, poucos são os jovens que conhecem a conferência. Desta forma, os empecilhos e dificuldades advindos da divulgação é algo do macro que reverbera no micro e vice-versa.

Talvez, para atrair outros jovens, a organização das conferências pudesse adotar estratégias para chegar aos que não estão nos espaços instituídos, convidando à participação de uma forma que consiga minimizar os impactos da visão deturpada que temos da política, provocada pela política partidária. A partir da experiência como organizador, acredito que temos que ter ciência de que este tipo de evento não desperta o interesse de vários outros jovens, como exposto por Lara e Théo.

B) Apoio do poder público, igrejas e escolas: Os organizadores fazem críticas no que tange ao apoio para realização e à dificuldade encontrada em muitas escolas e igrejas para adentrar no espaço e divulgar a conferência.

Para os organizadores, o maior envolvimento da escola, não apenas durante a divulgação, mas também em incorporar nas aulas e abordar a existência destes espaços participativos em seu cotidiano, é apontado também como empecilho, o mesmo aparecendo em fala de participantes:

Pedro: Quando nós fomos em especial nas escolas para estar buscando o jovem das escolas, a questão seria mais a temática, se eu não explicasse muito bem o que estaria acontecendo lá era muito difícil de os alunos estarem indo e em especial até a própria instituição de estar autorizando eles a participarem. Nós encontramos, foi encontrado inclusive dificuldades em muitas escolas até para estar, assim, entrando e estar conversando com aquele jovem, não há essa preocupação, praticamente as escolas se preocupavam mais na questão do que o Estado colocava e isso bastava, eles não queriam deixar, por exemplo, a sociedade estar entrando e estar colocando algo diferente.

Enzo: Bom, acho que, dentro da escola acho que seria a base pra isso, que talvez seja um ambiente que não seja discutido esse tipo de situação, política. Acho que não é discutido isso dentro da escola. A partir do momento que as pessoas sabem disso dentro da escola, fica muito mais fácil de... deles correrem atrás... várias pessoas que eu tenho conversado, falam dessa questão que a escola poderia, esse debate poderia ser feito dentro da 
escola... anhan... até mesmo assim, o próprio debate de política pode ser feito na escola...Porque eu acho que isso tem que ser, é... a iniciativa tem que partir de alguém que saiba sobre o assunto, tem que ter um articulador disso tudo, então, a partir do momento que você tem alguém que passe a frente e coloque esse espaço dentro da escola, é fácil de discutir, só que se o jovem em si, que não tem conhecimento, ele não vai tomar essa iniciativa.

São problematizadas a permissão para utilizar o espaço da escola para divulgação, bem como a sugestão de parceria entre conferência e escola, tornando este espaço algo mais palpável e menos abstrato aos jovens. Esta segunda problematização surge para além de um evento, mas como um processo permanente. Ainda sobre isto, a participante Amanda ressalta a importância desta parceria.

\begin{tabular}{l} 
Amanda: A conferência da juventude... para ela acontecer... eu acho que \\
seria interessante ENVOLVER... de uma forma comprometida ahn... as \\
\hline escolas... eu acho que é envolver todas as escolas talvez seria bem... \\
\hline complicado... mas vamos lá... se de repente a conferência começasse a \\
\hline acontecer ahn... não sei... duas vezes por ano... e no primeiro semestre \\
\hline acontece em uma escola... e aquela escola não só cedeu espaço... mas de \\
fato está envolvida com aquele espaço e transformar essas conferência... por \\
exemplo... como se fosse uma feira científica... alguma coisa assim... em que \\
os alunos tivessem a participação e.... com isso tivesse digamos algum tipo \\
de trabalho envolvido com as matérias que de fato teria que estar \\
comprometida com isso... história... geografia... que eram essas histórias... e \\
ENVOLVER mesmo... mas de uma forma pesada... e aí essa conferência \\
acontecesse nessa escola... ou no máximo duas escolas... mas eu acredito \\
que em cada escola... porque se a gente fizer em uma escola... mas se fizer \\
de uma forma COMPROMETIDA... envolvida e SÉRIA... apresentando um \\
resultado... eu acho que seria muito mais positivo... e.... aí fazendo nas outras \\
escolas...porque se você conseguir fazer com que essas pessoas entendam \\
éh.:.: exatamente a razão disso... a hora que você for no segundo semestre \\
para outra escola... você vai ter conseguido conquistar aqui pessoas que vão \\
BATALHAR para isso também... e aí você vai construir um exército de \\
pessoas que estão dispostas a fazer... a batalhar... não por alguma política... \\
não por um partido... mas por uma cidade. (grifos meus)
\end{tabular}

Vejo a importância de problematizar nesta narrativa o contraste entre este subtema e o subtema "como ficou sabendo". O contraste surge quando, mesmo com todas estas dificuldades, a escola ainda aparece como um dos espaços de conhecimento da conferência, através da divulgação feita pelos organizadores.

Outro aspecto é o narrado por Dandara, durante a entrevista, de que a motivação para estar na conferência estaria associada à possibilidade - tendo em vista que a escola não tem dado conta - de promover determinados diálogos que o espaço da conferência possibilitava.

A partir destes pontos, me pergunto se os tensionamentos entre escola e comissão organizadora da conferência não estariam relacionados à associação de conferências com partidos políticos, ou candidatos, especificamente. Ou ainda à 
constante reclamação de professores, por terem suas aulas interrompidas, ou a preocupação com a segurança da comunidade escolar.

Apesar disto tudo, a escola é vista por pessoas da organização e por participantes como a parceira ideal para atrair os jovens, e para contribuir com a escola em lacunas visualizadas por eles no debate da realidade local, bem como da temática política e cidadania. O que me resta é questionar como estreitar esta relação.

Outra instituição ou dispositivo visto como fonte de tensionamento com as conferências é o espaço religioso, que também figura como um dos pontos que mais proporciona, na realidade do município, o conhecimento das conferências. Apareceu na fala do organizador Pedro a disputa de poder entre igrejas como um empecilho. $A$ associação a católicos relacionados à organização levou algumas igrejas evangélicas a impedirem divulgação em seus espaços. Isso ocorreu na primeira edição em 2008 , que coincidiu com ano eleitoral, levando um vereador evangélico a proibir que no espaço de sua igreja e da igreja de seu assessor ocorresse a divulgação.

Para superar este obstáculo, eu e outros organizadores fizemos a panfletagem em carros, e nas ruas, após a saída do culto. Algumas vezes, grupos religiosos ligados a políticos ou partidos optavam por compor a organização, sem de fato envolver-se com a articulação, deixando a organização dias antes da realização da conferência (2011 e 2015).

Pedro: Quando a gente buscava o jovem na questão religiosa tinha muito a questão "não, eu pertenço a tal denominação, e a minha denominação não concorda, então eu não vou", isso era uma coisa também muito complicada, o diálogo entre as várias religiões foi muito difícil. (grifos meus)

C) Dia escolhido para realização do evento: Foi apresentada como dificuldade para participação dos jovens a realização da conferência aos sábados ou domingos, bem como a utilização de dois períodos. Para alguns entrevistados, isto tem impossibilitado a participação de jovens tendo em vista que a rotina e as escolhas feitas por eles acabam secundarizando a participação na conferência.

Thaís: Então, eu sei que eu já tentei, já, já estou por dentro, mas, olhando de fora, o que poderia ser diferente é uma banda que atrai mais ou até mesmo um DJ, porque agora a galera gosta mais de música eletrônica. Um DJ, um tempo mais curto, porque acho que foi muito extensivo, também. E o dia todo. Porque a galera quer dar rolê e aí, entendeu? Por ser o dia todo, também, mas é isso, é tentar, é que, é caro, né, mas tentar trazer atrações que vai chamar atenção, entendeu? (grifos meus)

Davi: Dificuldade também em arrumar pessoas... alguns jovens para se comprometerem mais com a causa... porque muitos estão em horário de 
est/estavam estudando... estão trabalhando... e não têm tempo né... aos finais de semana também acaba que sendo corrido...(grifos meus)

Tom: Os jovens que não estão ligados a nenhum grupo, seja ele de igreja, seja ele grupo de jovens, enfim, é, dificilmente, eu acho, iria participar. Porque... aconteceu num domingo, é isso? Um empecilho é acordar cedo, pro jovem. Ele já... de repente, seria, já acorda ou se estuda todo dia, cedo, de manhã, então ele quer o sábado e o domingo pra acordar um pouco mais tarde. Ou aquele que já tem um pouco mais de idade, 16, 17 anos, aí, né? É... terceiro colegial, segundo, terceiro colegial, ele já tá começando ir pra balada, então ele vai na balada de sexta e sábado e, no domingo, não quer acordar de manhã, né? Então ele prefere o quê? A balada do que ficar... na cabeça deles, penso eu que fala "ahn, esse bando de chato, aí, vai ficar falando essa chatice pra mim, eu vou lá pra fazer o quê? Eu já sei tudo". Jovem é meio arredio, né, meio, tem essa questão, esse ponto. (grifos meus)

O narrado por Thaís apresenta a dificuldade do dia escolhido para realização, porém lança como possibilidade a utilização de atrativos juvenis para romper com tais desafios, ao sugerir que uma balada seja realizada durante a conferência.

A participante Dandara traz dois aspectos importantes quando se refere aos desafios:

\begin{abstract}
Dandara: Então, eu acho que eu penso que é uma questão de interesse de momento. Na psicologia, a gente usa uma palavra que chama insight, que é o momento cultural, o contexto cultural. Naquele momento, eu acredito que tenha sido muito difícil articular aquela conferência, porque, quando você pensa uma conferência, além de pensar para esses grupos que eles já estão articulados, você quer que as outras massas participem. Eu participei enquanto um grupo articulado, mas queríamos que outras esferas da população participassem, que sejam professores, jovens que estejam inseridos em outro contexto, e que ele não necessariamente faz parte de um grupo. Então, eu acho que tem muito a ver com o momento. (grifos meus)
\end{abstract}

Por trás da dificuldade causada pelos dias da semana em que se realiza a conferência, estão fatores mais profundos, como a falta de interesse, rotina corrida, descrença política, ou o fato de conferência ser algo chato e de adulto. Há também a resistência do jovem, por não se sentir representado, ou não enxergar potência neste espaço.

Vale problematizar a dificuldade apresentada em 2008, quando a conferência teve dificuldade para atrair jovens que não estavam em grupos articulados, e isso me faz refletir sobre se a conferência pode atingir apenas grupos organizados. Mudar este quadro configura-se como um desafio que a organização tem encontrado dificuldades em superar.

Por outro lado, ao analisar os relatórios finais, também são identificados no credenciamento jovens sem vinculação a grupos ou entidades, que se denominam como estudantes, ou membros de uma igreja, sem de fato frequentar um grupo articulado. 
Apesar de reconhecer as dificuldades que a comissão organizadora tem para atingir jovens que não estão em espaços tradicionais de participação, assim como exposto por Dandara, o ato de sair de casa e ir à conferência não se desvincula de uma questão de momento e interesse por parte dos participantes. Desta forma, a não participação pode vincular-se também ao fato de que, para alguns jovens, o espaço da conferência não produz sentido quando confrontados com suas demandas pessoais.

D) Divulgação dos encaminhamentos e resultados: Mesmo não mencionado entre os empecilhos, quando indagados com a pergunta "Você conheceu os encaminhamentos e resultados da conferência?", vários entrevistados observaram o não conhecimento dos resultados e encaminhamentos pós-conferência.

Isto foi evidente entre os participantes, quanto aos resultados trazidos pelas conferências no que tange às políticas públicas de juventude no município. Porém, existe contraste nesta problematização.

Os participantes das edições de 2008 e 2011 conhecem os encaminhamentos, mas não têm conhecimento dos resultados que a conferência produziu. Já nas etapas mais recentes, tanto 2014, quanto 2015, os participantes em sua maioria dizem desconhecer tanto os resultados, quanto os encaminhamentos.

Acredito que esta produção esteja associada a não elaboração de um relatório oficial das edições, bem como sua entrega ao prefeito e seu consequente envio aos participantes, diferentemente do ocorrido nas duas primeiras edições.

Quanto à sistematização, o que possuímos da $3^{\text {a }}$ Conferência são apenas listas de credenciamento e lista de propostas apresentadas. Não me recordo da comissão organizadora e do conselho terem se debruçado de forma mais sistemática na avaliação desta edição. Isto talvez esteja associado à frustração da organização, devido ao número de participantes, por nós considerado pequeno. 


\section{7- CONSIDERAÇÕES}

Nesta pesquisa, tive por objetivo conhecer e problematizar os sentidos atribuídos às conferências, ao ser jovem/juventude e à participação juvenil, a partir do espaço das Conferências Municipais de Juventude em Santa Bárbara d'Oeste.

Para atingir este objetivo, percorri um caminho com voos e pousos pelos territórios das conferências, jovem/juventude e participação juvenil, territórios que avaliei como fundamentais para me aproximar do proposto. Estes voos e pousos só foram possíveis a partir da cartografia como método de pesquisa, auxiliada por três procedimentos metodológicos: (i) as entrevistas com participantes e organizadores das conferências municipais de juventude, que foram analisadas a partir da produção de mapas dialógicos; (ii) revisita aos relatórios finais das conferências municipais e nacionais de juventude; e (iii) e voos e pousos sobre/nas minhas memórias como participante de 3 edições das conferências nacionais e 4 edições das conferências municipais de juventude.

Com estes territórios alinhavados, através das entrevistas busquei problematizar quais os sentidos da conferência para os participantes, como tiveram conhecimento do evento e quais dificuldades e desafios estão presentes.

Ao voar e pousar no território das conferências, foi possível cartografar a diferença na maneira como a notícia sobre ela chega aos organizadores e participantes. Enquanto os organizadores ficam sabendo pelo portal da SNJ, por conhecerem e acompanharem esse espaço, ou ainda através de amigos que militam nas políticas públicas de juventude; os participantes tomam conhecimento através dos organizadores, que divulgam a conferência em escolas, igrejas, grupos juvenis e entre seus próprios amigos, fazendo ecoar a notícia da sua realização.

Depois de ecoada, as conferências adquirem diversos sentidos entre seus participantes. Entre eles estão o sentido de marco das políticas públicas para a juventude, de espaço de formação, espaço de planejamento, espaço de captura e espaço de devir.

Entre as dificuldades e desafios a serem superados, de acordo com os entrevistados, estão questões relacionadas à divulgação, ao pequeno de número de participantes, ao apoio de igrejas e escolas que acabam por dificultar a divulgação e a participação, à realização nos finais de semana, bem como à necessidade de aprimorar a divulgação dos resultados pós-conferência. 
Nas conferências, os jovens são capturados através de discursividades que fixam a identidade e a participação juvenil, reproduzindo formas de controle, que remetem aos jovens presentes, contornos discursivos que são esperados neste espaço.

As capturas presentes reverberam no território da participação, ao qual são atribuídos sentidos que remetem ao referencial que a sociedade tem da participação juvenil durante o período militar. A participação adquire, em consequência disto, caráter de militância, a partir de um jovem que é protagonista e sujeito na construção de seus direitos, ou alienado e desinteressado por rejeitar a participação através de espaços institucionalizados. Porém, em meio a estes sentidos capturados, a participação rizomática surge como devir e como espaço de "expressão dos desejos não compreendidos ou não 'encaixáveis"' (QUINTANILHA; DALBELLO-ARAUJO, 2014, p.103).

A participação rizomática amplia o sentido e a dimensão da participação por assumir que as conferências não são espaços exclusivos de manifestação dos desejos e das demandas juvenis em relação ao município (GUIZARDI, 2008; QUINTANILHA; DALBELLO-ARAUJO, 2014).

Dentre as motivações que levam os jovens a participarem deste espaço surgem o descontentamento com a realidade local, a familiaridade com o tema política e a imposição por lideranças de grupos e coletivos dos quais os jovens participam, que visualizam nestes espaços novas possibilidades de inserção juvenil. Outra motivação para participação nas conferências é a visualização da possibilidade de atender demandas pessoais.

Quando penso os sentidos do ser jovem/juventude, penso em territórios construídos discursivamente. Estes territórios, na sociedade moderna, recebem diversos contornos discursivos, transitando por problema, etapa da vida, protagonista, produto mercadológico, militante, alienado ou voluntário. A partir destes contornos, a juventude, além de ser territorializada, é subjetivada, sendo colocada em lugares de sujeitos fixos.

Ao analisar estas construções discursivas, bem como as narrativas que me foram apresentadas a partir das conferências municipais de juventude, tenho que a juventude assume contornos de ato performativo, conceito pensado a partir das teorias de gênero de Sara Salih e Judith Butler. 
Considerando juventude como ato performativo, penso que existem dispositivos produtores de identidades etárias, por meio dos quais os sujeitos jovens são forjados a partir de determinadas características e atitudes que são atreladas à juventude. Desse modo, considero que estes atos performativos se constituem como algo que não somos, mas fazemos, a partir de uma sequência de atos ou de devires. Assim, não temos uma identidade etária, mas nos tornamos determinadas identidades etárias, a partir de construções discursivas.

Este tornar-se jovem seria produzido por dobras, que refletem em uma multiplicidade juvenil definida por características e atitudes que são tomadas pelos sujeitos independentemente das suas idades.

No que tange ao ser jovem, em Santa Bárbara foi possível observar o apontamento da falta de atenção do poder público para as políticas públicas de juventude, o ecoar da juventude vista como problema na sociedade barbarense, a ausência de espaços voltados ao lazer, cultura e tempo livre, e relatos quanto à repressão policial e falta de espaços de participação.

Durante a banca de qualificação, fui provocado a pensar o título desta dissertação $O$ que a rebeldia teima? Capturas e resistências nas conferências de juventude em Santa Bárbara d'Oeste e, diante disso, apresento as possibilidades de capturas, resistências e rebeldias no espaço das conferências.

Penso que as capturas estão nas concepções que negam o devir criativo, assumindo os rótulos de segmentos etários ao conceber a juventude enquanto problema e como jovens alienados, vistos também como jovens individualistas e desinteressados da realidade local.

As capturas se fazem presentes, seja no território da juventude, das conferências ou da participação quando "os dispositivos de poder pretendem controlála, diminuir sua potência ontológica ao definir coletivos autorizados ao seu exercício e excluir a ação de outros como ilegítima" (GUIZARDI, 2014, p.34).

As resistências estão nos movimentos nômades, que fogem à captura ao negar as subjetivações modernas e constroem, no devir criativo, novas formas de ser e fazer-se jovem, acreditando, sonhando e produzindo inventividade a partir do desejo. As resistências se constituem enquanto "batalhas contra o "governo da individualização'” (FOUCAULT, 1995, p.235).

Este jovem que é subjetivado também produz e transforma subjetividades relacionadas à juventude e a outras identidades. Nesse sentido, as resistências 
produzidas e os espaços criados podem também reverberar em novas formas de capturas, que podem fixar sujeitos, sentidos de lugares e espaços de participação, estriando o espaço que até então se constituía como espaço liso.

Ao tomar as conferências como território de minhas problematizações, reconheço nesse ambiente a complexa rede de relações de poder que se delineiam sobre esse espaço de participação, permeado por resistências e capturas no processo de subjetivação da juventude e da participação, que são tensionadas, em especial, nos processos decisórios ao eleger delegados, ou indicar as propostas prioritárias.

As conferências passam a se configurar como espaços de possibilidade, quando, rejeitadas pela educação maior, se constituem como um espaço de educação menor, permitindo aos jovens vivenciar, debater e viver coisas que não thes são possibilitadas nos espaços de educação maior. São possibilidades também quando, como espaço de formação para a cidadania, potencializam devires, permitindo ao jovem reverberar outros sentidos para este espaço, para além dos sentidos e objetivos instituídos.

As conferências são possibilidades quando permitem aos jovens o encontro com o outro. A partir do encontro, se potencializam desejos e relações, rejeitando os contornos discursivos atribuídos à juventude, pensando o local, sonhando com novas possibilidades de fazer política, e mostrando que a juventude problema e alienada muitas vezes reverberada não é a juventude presente e nem mesmo a esperada para a conferência.

Desta forma, é a teimosia da juventude que rejeita determinadas subjetivações, produz novas subjetivações ao se organizar, ao sonhar, ao mudar. A teimosia da juventude se fez presente nas conferências reverberando na possibilidade de estar em espaços tanto regionais, estaduais, como nacional, com outros jovens, potencializando novas criações. A teimosia se faz presente quando a juventude neste espaço estriado das conferências produz possibilidades de participação rizomática. $A$ juventude vai a este espaço não apenas para apresentar propostas e demandas no uso tradicional da política, mas para vivenciar atividades culturais, esportivas e afetivas e produzir novas formas de participação rizomática além dele.

A teimosia se faz presente também no desejo dos organizadores em realizar a conferência e sonhar políticas públicas para a juventude. Foi a partir da conferência que no âmbito municipal se passou a ter leis para pensar as políticas públicas para a 
juventude, inclusive um Conselho Municipal de Juventude, conseguido após muita polêmica.

As conferências que potencializam a juventude também se constituem como um espaço de captura onde o contorno discursivo esperado é o de jovem militante ou de jovem sujeito de direito, que é protagonista na construção das políticas públicas de juventude.

Nas conferências, as capturas são engendradas desde o tema e lemas escolhidos e estão nas formas de divulgação, em que o convite à participação se reverbera em provocação ao jovem para que saia do comodismo e produza novas formas de fazer e pensar a política e de assumir o papel de ator estratégico no desenvolvimento local e nacional.

Neste percurso que me levou às conferências, a religião teve papel primordial em minha trajetória. Foi a partir da PJ da Igreja Católica, que me constitui enquanto jovem militante, que distingui possibilidades de participar das conferências. Foi também no espaço da PJ que adotei produções discursivas acerca da juventude e do jovem, que até o ingresso no programa de mestrado encontravam-se cristalizadas em $\operatorname{mim}$.

A Pastoral da Juventude me possibilitou vivenciar as conferências que se constituíram como espaço de formação, para compreender as questões políticas, tanto locais, como em nível nacional, permitindo ainda o reconhecimento do permear das relações de poder.

Cheguei a este programa de mestrado como um jovem cheio de sonhos, porém formatado pelo discurso oficial, construído e capturado pelo discurso da política nacional de juventude, da igreja católica e do partido político ao qual sou vinculado. Ao longo de minha trajetória, meu objeto de pesquisa me possibilitou visualizar a dimensão desta captura. Neste contexto, a desilusão inicial provocada por estas descobertas se converteu em um sonhar a partir de outro lugar, de outras problematizações que se, por um lado, desmancharam alguns sonhos, por outro me fortaleceram para lutar por antigos e também novos sonhos, ainda que as capturas fossem inevitáveis.

Esta desilusão também está no campo da participação, quando a rebeldia inicial passa a ser utilizada para capturar as juventudes e suas possibilidades de participação. Porém, como viver é estar mergulhado em complexas relações de poder, a teimosia consiste em continuar e a partir daí criar espaços que, apesar das 
dificuldades e desafios, passam a se constituir como novas possibilidades de escuta, de devir e teimosia juvenil. $E$ isso foi possibilitado pelas conferências, a partir da reivindicação e criação de marcos legais, com a constituição de espaços como o CoMJuv, a Semana Municipal de Juventude que, mesmo frágeis, existem e aí estão para serem apropriados e ressignificados pela juventude.

Assim como minha trajetória, penso que tanto conferência, quanto juventude e participação podem ser concebidas a partir de um olhar menos binário, em que capturas e resistências coexistam nestas relações de poder que produzem discursividades. Onde a rebeldia e a resistência se configurem e produzam novas formas de fazer política, em construções que potencializem o que a juventude tem de melhor, o desejo de viver e de produzir devir a partir do encontro. 


\section{REFÊRENCIAS ${ }^{85}$}

ABRAMO, H. W.; BRANCO, P. P. M. (org.) Retratos da juventude brasileira: análises de uma pesquisa nacional. São Paulo: Editora Perseu Abramo, 2008, 448 p.

ABRAMOVAY, M.; ANDRADE, E. R.; ESTEVES, L.C.G. (org.) Juventudes: outros olhares sobre a diversidade. Brasília: Ministério da Educação, Secretaria de Educação Continuada, Alfabetização e Diversidade; UNESCO 2007.

AGUIAR, T. M.B. O discurso (psico) pedagógico sobre a adolescência: análise dos impasses docentes provocados pela teorização da adolescência. 2007.

Dissertação (Mestrado em Educação) - Faculdade de Educação, Universidade de São Paulo, São Paulo, 2007. Disponível em:

<http://www.teses.usp.br/teses/disponiveis/48/48134/tde-31052007-104141/ptbr.php> Acesso em: 10 jan.2015.

ALMEIDA, R. S. Juventude e participação: novas formas de atuação juvenil na cidade de São Paulo. 2009. 129f. Dissertação (Mestrado em Ciências Sociais) Pontifícia Universidade Católica de São Paulo, São Paulo, 2009.

ANDRADE, M.H.M. Ser e performar no ciberespaço 1.5: uploads sobre (re) criações de si para inclusão em uma cultura popular digital. Revista Cambiassu, São Luís, v.15, n.17, p. 150-165, julho/dezembro 2015.

ALVES, Z.M.M.B.; SILVA, M.H.G.F.D. Análise qualitativa de dados de entrevistas: uma proposta. Paidéia, FFCLRP - USP, Ribeirão Pretro, 2, fev/jul, 1992.

ANCHIETANUM,Jesuitas. Já começou a preparação para a $1^{\text {a }}$ Conferência Nacional de Juventude. Disponível em: < http://www.anchietanum.com.br/site/ler_noticias.php?intldNoticia=55>Acesso em: 10 abr.2014.

ANTOUN, H. As Dobras do Poder. Jornal do Brasil Idéias/LIVROS, Rio de Janeiro, v. 279, p. 4 - 5, 01 fev. 1992.

ARENDT, H. O que é política? Rio de Janeiro: Bertrand Brasil, 2004, p. 21-28.

ARIÈS, P. História Social da Criança e da Família. Rio de Janeiro: Editora Guanabara Koogan, 1981.

AVRITZER, L. Conferências Nacionais: ampliando e redefinindo os padrões de participação social no Brasil. Disponível em: <

http://repositorio.ipea.gov.br/bitstream/11058/1137/1/TD_1739.pdf> Acesso em: 30 out.2013.

85 De acordo com a Associação Brasileira de Normas Técnicas. NBR 6023 (2002). 
BARBALHO, A. No ar da diferença: mídia e cultura nas mãos da juventude. Comunicação e Informação, v.9, n. 1, p.8-15, jan./jun.2006.

BARROS, L. P.; KASTRUP, V; Cartografar é acompanhar processos. In: PASSOS, E; KASTRUP, V; ESCÓSSIA, L. (Orgs). Pistas do Método da Cartografia: pesquisa-intervenção e produção de subjetividade. Porto Alegre: Sulina, 2015, p. 5275.

BORGHOSSIAN, C. O.; MINAYO, M.C.S. Revisão sistemática sobre juventude e participação nos últimos 10 anos. Saúde e Sociedade. São Paulo, v.18, n.3, p.411423, 2009.

BORDENAVE, J. E. D. O que é participação. 6. ed.São Paulo: Editora Brasiliense, 1995.

BOURDIEU, P. A. "juventude" não é apenas uma palavra. IN: BORDIEU, P. Questões de sociologia. Rio de Janeiro: Marco Zero, p. 112-121. Disponível em: < http://www.observatoriodoensinomedio.ufpr.br/wp-content/uploads/2014/04/ajuventude-e-apenas-uma-palavra-bourdieu.pdf> Acesso em: 07 fev. 2014.

BRASIL. Congresso. Lei n. ${ }^{\circ}$ 378/1937 - Dá nova organização ao ministério da Educação e Saúde Pública, 1937.

BRASIL. Constituição.Brasília:Senado Federal,1988. Disponível em: <http://www.planalto.gov.br/ccivil_03/constituicao/constituicao.htm> Acesso: 10 ago.2013.

BRASIL. Lei Federal n. 8069, de 13 de julho de 1990. Dispõe sobre o Estatuto da Criança e do Adolescente, e dá outras providências. Disponível em: < http://www.planalto.gov.br/ccivil_03/LEIS/L8069.htm> Acesso em: 04 mai.2012

BRASIL. Lei Federal n. 10.683, de 28 de maio de 2003. Dispõe sobre a organização da Presidência da República e dos Ministérios, e dá outras providências. Disponível em: <http://www.planalto.gov.br/ccivil_03/constituicao/Emendas/Emc/emc65.htm> Acesso em: 04 mai.2012

BRASIL. Secretaria-Geral da Presidência. Decreto de 5 de setembro de 2007. Convoca a 1a Conferência Nacional de Políticas Públicas de Juventude. Diário Oficial da União. Brasília, 6 set. 2007. Disponível em: <http// www.juventude.gov.br> Acesso em: 9 nov. 2013.

BRASIL. Secretaria Nacional de Juventude. $1^{\text {a }}$ Conferência Nacional de Juventude: Levante sua Bandeira - Documento Base. [s.I.]: Instituto Paulo Freire, 2007.

BRASIL. Emenda Constitucional n. 65, de 13 de julho de 2010. Altera a denominação do Capítulo VII do Título VIII da Constituição Federal e modifica o seu art. 227, para cuidar dos interesses da juventude. Disponível em: <http://www.planalto.gov.br/ccivil_03/constituicao/Emendas/Emc/emc65.htm> Acesso em: 04 maio 2012. 
BRASIL. Guia de Políticas Públicas de Juventude. Brasília: Secretaria-Geral da Presidência, 2013.

BRASIL. Lei n. ${ }^{\circ}$ 12.852, de 05 de agosto 2013. Institui o Estatuto da Juventude e dispõe sobre os direitos dos jovens, os princípios e diretrizes das políticas públicas de juventude e o Sistema Nacional de Juventude - SINAJUVE. Brasília, 2013. Disponível em: <http://www.planalto.gov.br/ccivil_03/_Ato20112014/2013/Lei/L12852.htm> Acesso em: 10 ago.2013.

BRASIL. Congresso. Câmara dos Deputados. Projeto de Decreto Legislativo n. ${ }^{\circ}$ 1491/2015. Susta a aplicação do Decreto n. ${ }^{\circ} 8243$, de 23 de maio de 2014, que institui a Política Nacional de Participação Social - PNPS e o Sistema Nacional de Participação Social - SNPS, e dá outras providências. Disponível em: < http://www.camara.gov.br/proposicoesWeb/fichadetramitacao?idProposicao=617737 > Acesso em: 10 dez. 2015.

BRASIL. Congresso. Senado. Projeto de Decreto Legislativo n. ${ }^{\circ} 147$, de 3 de novembro de 2014. Susta a aplicação do Decreto n. ${ }^{\circ} 8243$, de 23 de maio de 2014 , que institui a Política Nacional de Participação Social - PNPS e o Sistema Nacional de Participação Social - SNPS, e dá outras providências. Disponível em:

<http://www25.senado.leg.br/web/atividade/materias/-/materia/118766> Acesso em: 10 dez.2015.

BRASIL. Medida provisória n. ${ }^{\circ} 696$, de 2 de outubro de 2015. Extingue e transforma cargos públicos e altera a Lei n. ${ }^{\circ} 10683$, de 28 de maio de 2003, que dispõe sobre a organização da Presidência da República e dos Ministérios. Disponível em: <http://www.planalto.gov.br/ccivil_03/_Ato2015-2018/2015/Mpv/mpv696.htm> Acesso em: 12 dez.2015.

BRASIL. Presidência. Dialoga Brasil. Disponível em: < http://dialoga.gov.br/> Acesso em: 18 out.2015.

BRASIL. Secretaria-Geral da Presidência da República. Participa.br. Disponível em: <http://www.participa.br/> Acesso em: 07 set.2015.

BRASIL. Secretaria-Geral da Presidência da República. Direitos da juventude: subsídios para o debate. Brasília, DF, 2015. Disponível em: < http://juventude.gov.br/articles/participatorio/0011/0384/DIREITOdas_JUVENTUDES _OK.pdf> Acesso em: 07 set.2015.

BRASIL. Secretaria Nacional de Juventude. $1^{\text {a }}$ Conferência Nacional de Juventude. Disponível em: <http://juventude.gov.br/conferencia/1a-conferencianacional-de-juventude/ > Acesso em: 07 nov.2015.

BRASIL. Secretaria Nacional de Juventude. $1^{\text {a }}$. Conferência Nacional de Juventude . Caderno de Resoluções. Disponível em: < https://registrojuventude.files.wordpress.com/2011/02/revista-da-conferc3aancia.pdf > Acesso em: 07 nov.2015. 
BRASIL. Secretaria Nacional de Juventude. Galeria de fotos da $1^{\text {a }}$ Conferência Nacional. Disponível em: <http://juventude.gov.br/conferencia/galeria-de-fotos-1aconferencia-nacional-de-juventude> Acesso em: 07 nov.2015.

BRASIL. Secretaria Nacional de Juventude. $2^{\text {a }}$ Conferência Nacional de Juventude. Disponível em: <http://juventude.gov.br/conferencia/2a-conferencianacional-de-juventude/> Acesso em: 10 set.2015.

BRASIL. Secretaria Nacional de Juventude. Texto base da $2^{\text {a }}$ Conferência Nacional de Juventude. Disponível em: < http://juventude.gov.br/articles/participatorio/0016/4420/20110617181625texto_base _da_2a_conferencia_de_juventude_1_.pdf> Acesso em: 10 set.2015.

BRASIL. Secretaria Nacional de Juventude. Propostas finais da $2^{\mathrm{a}}$ Conferência Nacional de Juventude. Disponível em: < http://issuu.com/participatorio/docs/propostas_finais_da_ii_confer_ncia/1> Acesso em 10 set.2015.

BRASIL. Secretaria Nacional de Juventude. CFESS Manifesta da $2^{a}$ Conferência Nacional de Juventude. Disponível em: < http://juventude.gov.br/articles/participatorio/0016/4417/cfessmanifesta2011_conf.juv eSITE.pdf> Acesso em: 10 set.2015.

BRASIL. Secretaria Nacional de Juventude. Fotos da $2^{\text {a }}$ Conferência Nacional de Juventude. Disponível em:

<https://www.facebook.com/SecretariaNacionaldeJuventude/photos/a.195947587181 104.39394.120381061404424/195978873844642/?type=3\&theater> Acesso em: 7 abr. 2014.

BRASIL. Secretaria Nacional de Juventude. $3^{\text {a }}$ Conferência Nacional de Juventude. Disponível em: <http://juventude.gov.br/conferencia/> Acesso em: 07 jul.2015.

BRASIL. Secretaria-Geral da Presidência da República. Sistema de Participação Social. Disponível em:

$<$ http://www.secretariageral.gov.br/art_social/publicacoes/sistema-de-participacaosocial-1> Acesso em: 11 nov.2013.

BRASIL. Secretaria-Geral da Presidência da República. Folder de Participação Social. Disponível em: < http://www.secretariageral.gov.br/art_social/publicacoes/folder-participacao-social> Acesso em: 11 nov.2013.

BRASIL. Secretaria de Governo. Conferências Nacionais, Gráfico, 1941-2013. Disponível em:< http://www.secretariageral.gov.br/participacaosocial/conferencias/conferencias-nacionais-grafico-1941-2013/view>. Acesso em: 10 nov.2015. 
BRASIL. Secretaria-Geral da Presidência da República. Calendário das

Conferências Nacionais 2015-2016. Disponível em:<

http://www.participa.br/portal/blog/calendario-das-conferencias-nacionais-2015-

2016. >. Acesso em: 10 nov.2015.

BUTLER, J. Problemas de gênero: feminismo e subversão da identidade. Rio de Janeiro: Civilização Brasileira, 2003.

BUTLER, U. M.; PRINCESWAL, M. Culturas de participação: jovens e suas percepções e práticas de cidadania. $\mathbf{O}$ social em questão, Rio de Janeiro, n.27, p. 101-126, 2012.

CAMPOS, M. T. A. A adolescência inventada e os sujeitos que se inventam na participação social: capturas e resistências. 2008. Dissertação (Mestrado em Educação) - Faculdade de Educação, Universidade de Campinas, 2008. Disponível em: < http://www.bibliotecadigital.unicamp.br/document/?code=vtls000437952> Acesso em: 12 jun.2014.

CASTRO, E. Vocabulário de Foucault. Belo Horizonte: Autêntica Editora, 2009.

CÉSAR, M. R. A. A Invenção da “Adolescência” no Discurso Psicopedagógico (Mestrado em educação) - Faculdade de Educação da Universidade Estadual de Campinas, Campinas, 1998.

COIMBRA, C.C.; BOCCO, F.; NASCIMENTO, M.L. Subvertendo o conceito de adolescência. Arquivos Brasileiros de Psicologia, v. 57, n.1, p. 2-11, 2005.

COSTA, J. F. Perspectivas da juventude na sociedade de mercado. In: NOVAES, R.; VANNUCHI(Org.) Juventude e Sociedade. São Paulo: Editora Perseu Abramo, 2004, 75- 88p.

CORTES, S. M. V. Conselhos Municipais de Saúde: a possibilidade dos usuários participarem e os determinantes da participação. Ciência e Saúde Coletiva, Rio de Janeiro, v. 3, n. 1, p. 5-17, 1998.

CORTES, S. M. V. Construindo a possibilidade da participação dos usuários: conselhos e conferências no sistema único de saúde. Sociologias, Porto Alegre, ano 4, n. 7, p. 18-49, jan-jun, 2002.

COSTA, J. H. Subjetivação e dobras de fora: transitando por Foucault, de Gilles Deleuze. In: Trilhas Filosóficas. Natal, ano III, número 1, jan-jun.2010, p. 30-40, Disponível em: <

http://www.uern.br/outros/trilhasfilosoficas/conteudo/N_05/III_1_art_2_Costa.pdf>. Acesso em: 7 de ago.2015.

CRIVELARO, R. A capacidade inclusiva das conferências de juventude em Santa Bárbara d'Oeste - SP. 2013. 101f. Trabalho de conclusão de curso (Especialização em Juventude no Mundo Contemporâneo) - Pontifícia Universidade Católica de Goiás/ Rede Brasileira de Centros e Institutos de Juventude, Goiânia. 
CRIVELARO, R. Conferências nacionais como instrumentos de participação. In: SEMINÁRIO INTERNACIONAL DE PESQUISA EM POLÍTICAS PÚBLICAS E DESENVOLVIMENTO LOCAL, 1, 2009, Franca. Anais...Franca: UNESP, 2014, p.117. Disponível em: < http://www.franca.unesp.br/Home/Pos-graduacao/planejamentoeanalisedepoliticaspublicas/isippedes/rodrigo-crivelaro.pdf $>$ Acesso em: 07 mar.2015.

CRUVIEL, M. V. Corpos indóceis: juventude, identidade e (emo)ção. Revista Movendo Ideias, Belém, v. 15, n.1, jan-jun, p. 67-71, 2010.

CRUZ, E.F. Espelhos d'AIDS: infâncias e adolescências nas tessituras da AIDS. 2005. Tese (Doutorado em Educação) - Faculdade de Educação, Universidade de Campinas, Campinas, 2005. Disponível em: < http://www.bibliotecadigital.unicamp.br/document/?code=vtls000377441> Acesso em: 23 maio 2015.

CUNHA, C.F.C. Gilles Delleuze e o pensamento nômade: a máquina de guerra primitiva. In: Semana de Orientação Filosófica e Acadêmica, 8., 2014, Guarulhos. Anais... São Paulo: Editora Edgard Blucher, 2014. p. 58-65. Disponível em: < http://pdf.blucher.com.br/philosophyproceedings/viii-sofia/008.pdf> Acesso em: 15 jun.2015.

DEBERT, G.G. A dissolução da vida adulta e a juventude como valor. A dissolução da vida adulta e a juventude como valor. Horizontes Antropológicos. Porto Alegre, ano 16, n.34, p.49-70, jul/dez.2010.

DELEUZE, G. Controle e devir. In: DELEUZE, G. Conversações. São Paulo: Editora 34, 1992, p. 209-218.

DELEUZE, G. As dobras ou o lado de dentro do pensamento (subjetivação). In: DELEUZE, G. Foucault. São Paulo: Brasiliense, 2005, p. 101-130.

DELEUZE,G; GUATTARI, F.; Mil platôs: capitalismo e esquizofrenia. Volume 1.São Paulo: Editora 34, 2000

DELEUZE, G.; GUATTARI, F. O liso e o estriado. IN: DELEUZE, G; GUATTARI, F.; Mil platôs: capitalismo e esquizofrenia. São Paulo: Editora 34, 1997, p. 157-189.

DELEUZE, G.; PARNET, C. Políticas. In: DELEUZE, G.; PARNET, C. Diálogos. São Paulo: Escuta, 1998, p. 101-120.

DEMOCRACIA JUSTIÇA E CONTROLE PÚBLICO. É preciso preparar os governos para a participação. 13/09/2013. Disponível em:

<http://democraciaejustica.org/cienciapolitica3/node/1224?page=10> Acesso em: 15.nov.2013.

DIAS, R. Construindo a democracia na cidade: a experiência de Rio Claro (SP). Rio Claro:[s.n.], 2002. Disponível em: < http://portal.mercociudades.net/sites/portal.mercociudades.net/files/archivos/docume 
ntos/Redes_y_experiencias/Construindo-democracia.PDF> Acesso em: 15 dez.2015.

FERRE, N.P.L. Identidade, diferença e diversidade: manter viva a pergunta IN: LARROSA, JORGE (org). SKLIAR, CARLOS (org). Habitantes de Babel políticas e poéticas da diferença. 2.ed. Belo Horizonte: Autêntica, 2011. p. 195-213.

FERNANDES, M.E.Memórias Camponesas. In: MATTOS, M.A.; GORAYB, R.; OTERO, V.L.R. (Orgs), 1991, Ribeirão Preto, SP: Anais da XXI Reunião Anual de Psicologia Ribeirão Preto, SP: Sociedade Brasileira de Psicologia, 1992. Disponível em: < http://www.sbponline.org.br/resources/anais/1991.pdf>. Acesso em: 7 nov.2015.

FONSECA, M. A. Para pensar o público e o privado: Foucault e o tema das artes de governar. In: RAGO, M; VEIGA-NETO, A.(Orgs.). Figuras de Foucault. Belo Horizonte: Autêntica, 2006.

FOUCAULT, M. O sujeito e o poder. In: DREYFUS, H. ; RABINOW, P.(Eds.) Michel Foucault, uma trajetória filosófica: para além do estruturalismo e da hermenêutica. Rio de Janeiro: Forense Universitária, 1995, p. 231-249.

FOUCAULT, M. Microfísica do poder. Rio de Janeiro: Graal, 1996.

FOUCAULT, M. Resumo dos cursos do Collége de France (1970-1982). Rio de Janeiro: Jorge Zahar Editor, 1997, p. 59-106.

FOUCAULT, M. A Hermenêutica do Sujeito. São Paulo: Martins Fontes, 2006.

FOUCAULT, M. Segurança, Território, População. São Paulo: Martins Fontes, 2008, p. 305-382.

FOUCAULT, M. Nascimento da Biopolítica. São Paulo: Martins Fontes, 2008.

FOUCAULT, M. Tecnologias del yo. Buenos Aires: Paidós, 2008, 152p..

FOUCAULT, M. Segurança, território e população. São Paulo: Martins Fontes, 2009.

FOUCAULT, M. A ordem do discurso. São Paulo: Edições Loyola, 2014.

FOUCAULT, M. A história da sexualidade: a vontade de saber. São Paulo: Paz e Terra, 2015.

FREITAS, S.A. Governar os incivilizados e os outsiders: apontamentos para uma analítica do poder em elias e foucault. In: SIMPOSIO INTERNACIONAL PROCESSO CIVILIZADOR, 12., 2009, Recife. Anais.... Recife: EDITORA DA UFPE, 2009. v. I. p. 03-16. Disponível em: < http://www.uel.br/grupo-

estudo/processoscivilizadores/portugues/sitesanais/anais12/artigos/pdfs/mesas_redo ndas/MR_Freitas.pdf> Acesso em: 10 out. 2014. 
FREZZA, M.; MARASCHIN, C.; SANTOS, N.S. Juventude como problema de políticas públicas. Psicologia \& Sociedade, v.21, n.3, p. 313-323, 2009.

FUNDAÇÃO ROMI. História. Histórico da Denominação. Texto e pesquisas: Antonio Carlos Angolini/Fundação Romi e João José (JJ) Bellani/jornalista e radialista esportivo. Publicado no Jornal Diário, em 04/02/2003. Disponível em $<\mathrm{http}$ ://www.fundacaoromi.org.br/fundacao/index.php?pag=padrao\&op=cedoc\&id=20 96\&op2=not\&cat=pesquisa-tematica> Acesso em: 20 set. 2015

GLOBO.COM. Estado tem dívida com o jovem, diz Lula, São Paulo. 28. 04. 2008. Disponível em:<g1.globo.com/Noticias/Politica/0,,MUL428395-5601,00.html> Acesso em: 31 jul.2009.

GALLO, S. Em torno de uma educação menor. Educação \& Realidade. Porto Alegre, v.27, n.2, p.169-178, jul-dez, 2002.

GOULART, M. V. S. Incursões biopolíticas: poder jovem nas tramas da arena pública. 2011. 111 f. Dissertação (Mestrado em Psicologia Social e Institucional). Instituto de Psicologia, Universidade Federal do Rio Grande do Sul, Porto Alegre, 2011.

GOULART, M. V. S. ; SANTOS, N. I. S. . Juventude, Biopolítica e Capital Social. In: Encontro Nacional da Associação Brasileira de Psicologia Social, 2009, 15, Maceió. Anais... Maceió, [s/n], 2009. Disponível em: < http://www.abrapso.org.br/siteprincipal/images/Anais_XVENABRAPSO/49.\%20juvent ude,\%20biopol\%CDtica\%20e\%20capital\%20social.pdf>. Acesso em: 15 de ago. 2014.

GUATTARI, F. Somos todos grupelhos. In: GUATTARI, F. Revolução molecular: pulsações políticas do desejo. São Paulo, Brasiliense, 1987, p.12-19.

GUATTARI, F.; ROLNIK, S. Subjetividade e História. In: GUATTARI, F.; ROLNIK, S. Micropolítica: cartografias do desejo. Petrópolis: Vozes, 1996. p. 25-76.

GROPPO, L. A. Juventude: Ensaios sobre Sociologia e História das Juventudes Modernas. Rio de Janeiro: DIFEL, 2000.

GROPPO, L. A. Movimento estudantil: um resquício do passado? IHU- Online. Revista do Instituto Humanista Unisinos. São Leopoldo.273, Ano VII,15 /09/ 2008. Entrevista concedida a Patrícia Fachin. Disponível em: < http://www.ihuonline.unisinos.br/index.php?option=com_content\&view=article\&id=21 35\&secao=273> Acesso em: 10 dez.2015.

GROPPO, L. A.Os múltiplos sentidos de ser jovem. Jornal UFG. Universidade Federal de Goias. Goiania. Ano VII. n.58, maio 2013. Entrevista concedida a Patrícia da Veiga. Disponível em http://www.jornalufgonline.ufg.br/n/46809-entrevista-osmultiplos-sentidos-de-ser-jovem Acesso em: 02 mai.2013. 
GROPPO, L.A. Teorias pós-críticas em juventude: juvenilização tribalismo e socialização ativa. Revista Latinoamericana de Ciencias Sociales, Niñez y Juventud, v.13, n.2, p.567-579, 2015a

GROPPO, L.A. Teorias críticas da juventude: geração social, e subculturas juvenis. Em tese, Florianópolis, v.12, n.1, p. 4-33, jan./jul., 2015b.

GROPPO, L.A.; ZAMARIAN, M.J. Juventude e voluntariado: considerações sobre o novo modelo de participação social e os jovens no Brasil. In: CONGRESSO BRASILEIRO DE SOCIOLOGIA, 14, 2009, Rio de Janeiro. Anais...Rio de Janeiro: Sociedade Brasileira de Sociologia, 2009, não paginado.

GUIZARDI, F. L. Considerações epistemológicas sobre democracia, poder e representação política. In: GUIZARDI, F. L. (Org.) Políticas de participação e saúde. Recife: Editora Universitária - UFPE, 2014.

GUIZARDI, F. L.; et. al. Participação da comunidade em espaços públicos de saúde: uma análise das conferências nacionais de saúde. Physis: Revista de Saúde Coletiva, Rio de Janeiro, v. 14, n. 1, p.15-39, 2004.

GUIZARDI, F.L. Política e soberania no estado moderno: uma introdução à questão da participação política no SUS. In: GUIZARDI, F.L. Do controle social à gestão participativa: perspectiva (pós-soberanas) da participação política no SUS.2008. 258f. Tese (Doutorado em Saúde Coletiva) - Instituto de Medicina Social, Universidade do Estado do Rio de Janeiro, Rio de Janeiro, 2008.

GUIZARDI, F. L. Do controle social à gestão participativa: interrogações sobre a participação política no SUS. Trabalho, Educação e Saúde, Rio de Janeiro, vol.7, n.1, pp. 9-34, 2009.

HALL, S. Quem precisa da identidade. In: SILVA, T.T. (Org.). Identidade e diferença: a perspectiva dos estudos culturais. Petrópolis: Vozes, 2007, p.103-133 p.

HALL, S. A identidade cultural da pós-modernidade. Rio de Janeito: DP\&A, 2011, $102 \mathrm{p}$.

HOCHMAN, G.. Reformas, instituições e políticas de saúde no Brasil (19301945). Educar em Revista, Curitiba, n.25, p.127-141, 2005.

HORTA, J.S.B. I Conferência Nacional de Educação ou de como monologar sobre educação na presença de educadores. In: GOMES, A.C. (Org.) Capanema: o ministro e seu ministério. Rio de Janeiro: FGV/USF, 2000, p.143-172.

IBGE. @Cidades - Santa Bárbara d'Oeste. Disponível em:

<http://cidades.ibge.gov.br/xtras/perfil.php?lang=\&codmun=354580\&search=saopaul olsanta-barbara-d\%60oeste> Acesso: em 10 Ago.2013.

KASTRUP, V; O funcionamento da atenção no trabalho do cartógrafo. In: PASSOS, E; KASTRUP, V; ESCÓSSIA, L (Orgs). Pistas do Método da Cartografia: 
pesquisa-intervenção e produção de subjetividade. Porto Alegre: Sulina, 2015, p. 3251.

KEHL, M. R. A juventude como sintoma da cultura. In: NOVAES, R.; VANNUCHI

(Org.) Juventude e Sociedade. São Paulo: Editora Perseu Abramo, 2004, 89- 114p.

KLEBA, M. E.; WENDAHAUSEN, A. Emponderamento: processo de fortalecimento dos sujeitos nos espaços de participação social e democratização política. Saúde e Sociedade, São Paulo, v.18, n.4, p. 733-743, 2009.

LARROSA, J. Tecnologias do Eu e Educação. In: SILVA, T.T. O sujeito da educação. Petropólis: Vozes, 1994. Disponível em: < http://www.grupodec.net.br/wpcontent/uploads/2015/10/TecnologiasdoEuEducacaoLarrossa.pdf>. Acesso em: 22 fev.2015.

LEMOS, F.C.S. Práticas de governo das crianças e dos adolescentes propostas pelo UNICEF e pela UNESCO: inquietações a partir das ferramentas analíticas legadas por Foucault. Psciologia \& Sociedade, Florianópolis, v.24(n.spe.), p. 52-59, 2012.

LEON, A.P.; DOLEJSIOVÁ, D.; FALANGOLA, T. Políticas Públicas de Juventude. Brasília: Fundação João Mangabeira, 2009.

LOPEZ, Felix; PIRES, Roberto. "Instituições Participativas e Políticas Públicas no Brasil: características e evolução nas últimas duas décadas". In: IPEA Brasil em Desenvolvimento. Brasília: IPEA, 2010.

MARTINS, M.L.; NEVES, J.P. As lágrimas amargas da participação: como pensar o "poder" a partir de Michel Foucault. Sociedade e Cultura 2, Cadernos do Nordeste, v. 13, n.2, p.51-65, 2000.

MARTINS, E.; ROSA, R.M. Juventude gay na zona rural: a dobra como processo de subjetivação. REUNIÃO ANUAL DA ASSOCIAÇÃO NACIONAL DE PEDAGOGIA, 36, 2013, Goiânia. Anais...Goiânia: 2013, não paginado.

MAYORGA, C. Identidades e Adolescências: uma desconstrução. Pesquisas e Práticas Psicossociais, São João del Rei, v. 1, n.1, , jun.2006. Disponível em: < http://www.seer.ufsj.edu.br/index.php/revista_ppp/article/view/504/470> Acesso em: 11 set. 2015.

NASCIMENTO, V.L.; TAVANTI, R. M.; PEREIRA, C.C.Q. O uso de mapas dialógicos como recurso analítico em pesquisas científicas. IN: SPINK, M. J.; BRIGAGÃO, J.; NASCIMENTO, V; CORDEIRO, M. A produção de informação na pesquisa social: compartilhando ferramentas. Rio de Janeiro: Centro Edelstein, 2014, p. 247-272.

NESPOLI, G. Biopolítica da participação na saúde: o Sus e o governo das populações. In: GUIZARDI, F. L. (Org.) Políticas de participação e saúde. Recife: Editora Universitária - UFPE, 2014. 
PASSOS, E; BARROS, R.B.; A cartografia como método de pesquisa-intervenção. In: PASSOS, E; KASTRUP, V; ESCÓSSIA, L. (Orgs). Pistas do Método da Cartografia: pesquisa-intervenção e produção de subjetividade. Porto Alegre: Sulina, 2015, p. 17-31.

PASSOS, E; KASTRUP, V; ESCÓSSIA, L (Orgs). Pistas do Método da Cartografia: a experiência da pesquisa e o plano comum - Volume 2. Porto Alegre: Sulina, 2015.

PERES, W.S. Juventudes, diversidades sexuais e processos de subjetivação. In: PESSINI, L.; ZACHARIAS, R. (Orgs.). Ética teológica e juventudes: interpelações recíprocas. Aparecida-SP: Editora Santuário, 2013, p.51-84.

PETINELLI, Viviane. As Conferências Públicas Nacionais e a formação da agenda de políticas públicas do Governo Federal (2003-2010). Opinião Pública [online]. 2011, vol.17, n.1, pp. 228-250. Disponível em < http://dx.doi.org/10.1590/S0104$62762011000100008>$ Acesso em: 31 out. 2013.

PINTO, C. R. J. As Conferências Nacionais no Brasil: uma experiência de esfera pública de médio alcance?. Interseções (UERJ), v. 2, p. 195-214, 2009.

POCAHY, F. A velhice como performativo: dissidências (homo) eróticas. Ex aequo, Fortaleza, n.26, p.43-56, 2012.

ATLAS DO DESENVOLVIMENTO HUMANO DO BRASIL. Perfil Santa Bárbara d'Oeste. Disponível em: < http://atlasbrasil.org.br/2013/perfil/santa-barbaradoeste_sp>. Acesso em: 10 ago.2013

QUINTANILHA, B. C.; DALBELLO-ARAUJO, M. Participação rizomática: um modo de participação social no sistema único de saúde. GUIZARDI, F. L. (Org.) Políticas de participação e saúde. Recife: Editora Universitária - UFPE, 2014.

RANCIÈRE, J. Democracia e consenso. In: RANCIĖRE, J. O desentendimento políticas e filosofia. São Paulo: Editora 34, 1996, p.99-122.

RIBEIRO, R. J. Política e juventude: o que fica da energia. In: NOVAES, R.; VANNUCHI (Org.) Juventude e Sociedade. São Paulo: Editora Perseu Abramo, 2004, 19-33p.

ROLNIK, S. O mal-estar na diferença. 1995. Disponível em: < http://www.pucsp.br/nucleodesubjetividade/Textos/SUELY/Malestardiferenca.pdf>. Acesso em: 12 ago.2015.

ROLNIK, S. Uma insólita viagem à subjetividade. Fronteiras com a ética e a cultura. In: LINS, D. (Org.). Cultura e subjetividade. Saberes Nômades. Campinas:

Papirus, 1997a, v. , p. 25-34. Disponível em: < http://caosmose.net/suelyrolnik/pdf/sujeticabourdieu.pdf>. Acesso em: 12 ago.2015.

ROLNIK, S. Toxicômanos de identidade subjetividade em tempo de globalização. In: LINS, D. (Org.). Cultura e subjetividade. Saberes Nômades. Campinas: Papirus, 
1997b, v. , p. 19-24. Disponível em: < http://caosmose.net/suelyrolnik/pdf/sujeticabourdieu.pdf>. Acesso em: 12 ago.2015.

ROMAGNOLI, R.C. et al.. Por uma clínica da resistência: experimentações desinstitucionalizantes em tempos de biopolítica. Interface, Botucatu, v.13, n.30, p.199-207, set.2009.

ROMÃO, W. M. Políticas públicas e democracia participativa. São Paulo: FriedrichEbert Stiftung, 2014. Disponível em: < http://library.fes.de/pdffiles/bueros/brasilien/10964.pdf> Acesso em. 10 out.2015.

SALIH, S. Judith Butler e a teoria queer. Belo Horizonte: Autêntica Editora, 2012.

SANTA BÁRBARA D'OESTE. Comissão Organizadora da $1^{\text {a }}$ Conferência Municipal de Juventude. Relatório final da $1^{\text {a }}$ Conferência Municipal de Juventude de Santa Bárbara d'Oeste-SP. Santa Bárbara d'Oeste: [s.n.], 2008.

SANTA BÁRBARA D'OESTE. Prefeitura. Lei Municipal n. ${ }^{\circ} 3170$, Institui a Semana Municipal da Juventude Barbarense no Município de Santa Bárbara d'Oeste, e dá outras providências. Disponível em: <

http://www.santabarbara.sp.gov.br/v5/index.php?pag=mostra_p\&dir=sec_de_negoci os juridicos\&t=jdvle000\&id=5977>. Acesso em: 20 set. 2015.

SANTA BÁRBARA D'OESTE. Prefeitura. Lei Municipal n. ${ }^{\circ} 3204$, de 18 de junho de 2010. Autoriza o Poder Executivo Municipal a participar do programa federal denominado "Projovem Trabalhador - Juventude Cidadã", no âmbito do Ministério do Trabalho e Emprego bem como a firmar Termo de Parceria com Organização da Sociedade Civil de Interesse Público, e dá outras providências. Disponível em: < http://www.santabarbara.sp.gov.br/v5/index.php?pag=mostra_p\&dir=sec_de_negoci os juridicos\&t=jdvle000\&id=6019>. Acesso em: 20 set. 2015 .

SANTA BÁRBARA D'OESTE. Prefeitura. Lei Municipal n. ${ }^{\circ} 3309$, de 4 de setembro de 2011. Dispõe sobre as Políticas Públicas de Juventude, cria o Conselho Municipal de Juventude, o Plano Municipal de Juventude e a Conferência Municipal de Juventude e dá outras providências.. Disponível em: < http://www.santabarbara.sp.gov.br/v5/index.php?pag=mostra_p\&dir=sec_de_negoci os juridicos\&t=jdvle000\&id=6160>. Acesso em: 20 set. 2015 .

SANTA BÁRBARA D'OESTE. Prefeitura. Notícia. Heins sanciona lei que cria o Conselho Municipal de Juventude. Disponível em: < http://www.santabarbara.sp.gov.br/v5/index.php?pag=noticia\&dir=noticias\&id=47487 > Acesso em: 20 set. 2015.

SANTA BÁRBARA D'OESTE. Prefeitura. Notícias. Beatriz Costa. Prefeito assina decreto e convoca a $2^{\text {a }}$ Conferência Municipal de Juventude. Disponível em: < http://www.santabarbara.sp.gov.br/v5/index.php?pag=noticia\&dir=noticias\&id=46686 > Acesso em: 20 set. 2015.

SANTA BÁRBARA. Prefeitura. Notícias. Thais de Matheu. Município se prepara para $1^{\text {a }}$ Conferência Nacional de Juventude. Disponível em: < 
http://www.santabarbara.sp.gov.br/v5/index.php?pag=noticia\&dir=noticias\&id=29018 $>$ Acesso em: 20 set.2015.

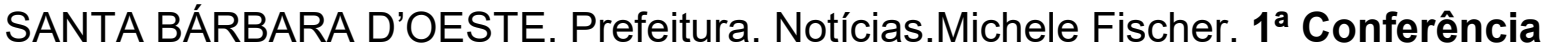
Municipal de Juventude segue até às 15h30. Disponível em: <

http://www.santabarbara.sp.gov.br/v5/index.php?pag=noticia\&dir=noticias\&id=26662 > Acesso em: 20 set.2015.

SANTA BÁRBARA D'OESTE. Prefeitura. Notícia. Santa Bárbara terá 4 delegados na Conferência Nacional de Juventude. Disponível em: < http://www.santabarbara.sp.gov.br/v5/index.php?pag=noticia\&dir=noticias\&id=48162 >. Acesso em: 20 set. 2015.

SANTA BÁRBARA D'OESTE. Comissão Organizadora da $2^{a}$ Conferência Municipal de Juventude. Relatório final da $2^{a}$ Conferência Municipal de Juventude de Santa Bárbara d'Oeste-SP. Santa Bárbara d'Oeste: [s.n.], 2011.

SANTA BÁRBARA D'OESTE. Prefeitura. Lei Municipal n. ${ }^{\circ} 3587$, de 18 de fevereiro de 2014. Cria o Fundo Municipal da Juventude, dando outras providências.

Disponível em: <

http://www.santabarbara.sp.gov.br/v5/index.php?pag=mostra_p\&dir=sec_de_negoci os_juridicos\&t=jdvle000\&id=6486> Acesso em: 20 set.2015.

SANTA BÁRBARA D'OESTE. Prefeitura. Notícia. Prefeitura e CoMJuv realizam a $3^{a}$ Conferência Municipal de Políticas Públicas de Juventude. Disponível em: < http://www.santabarbara.sp.gov.br/v5/index.php?pag=noticia\&dir=noticias\&id=56156 >. Acesso em: 20 set. 2015.

SANTA BÁRBARA D'OESTE. Prefeitura. Notícia. Jovens barbarenses participam da $3^{\text {a }}$ Conferência Municipal de Políticas Públicas de Juventude. Disponível em: $<$

http://www.santabarbara.sp.gov.br/v5/index.php?pag=noticia\&dir=noticias\&id=56261 $>$ Acesso em: 20. Set.2015.

SANTA BÁRBARA D'OESTE. Comissão Organizadora da $3^{a}$ Conferência Municipal de Juventude. Relatório final da $3^{a}$ Conferência Municipal de Juventude de Santa Bárbara d’Oeste-SP. Santa Bárbara d'Oeste: [s.n.], 2014.

SANTA BÁRBARA D'OESTE. Prefeitura. Notícia. 4ª Conferência Municipal de Juventude a âmbito nacional acontece em agosto. Disponível em: < http://www.santabarbara.sp.gov.br/v5/index.php?pag=noticia\&dir=noticias\&id=58797 > Acesso em: 20 set.2015.

SANTA BÁRBARA D'OESTE. Prefeitura.NotPrefeito Denis Andia participa da $4^{a}$ Conferência Municipal de Juventude. Disponível em: < http://www.santabarbara.sp.gov.br/v5/index.php?pag=noticia\&dir=noticias\&id=58969 > Acesso em: 20 set. 2015 . 
SANTA BÁRBARA D'OESTE. Comissão Organizadora da $4^{a}$ Conferência Municipal de Juventude. Relatório final da $4^{\mathrm{a}}$ Conferência Municipal de Juventude de Santa Bárbara d'Oeste - SP. Santa Bárbara d'Oeste: [s.n.], 2015.

SENELLART, M. Situação dos cursos. In: FOUCAULT, M. Segurança, Território e População. São Paulo: Martins Fontes, 2009, p. 495-538.

SCHLAUCHER, B.G.P. Telejornalismo e juventude na era da convergência midiática. CONGRESSO DE CIÊNCIAS DA COMUNICAÇÃO NA REGIÃO SUDESTE, 17, 2012, Ouro Preto-MG, Anais...Ouro Preto, 2012, p.1-15.

SCISLESKI, A.C.C.; MARASCHIN, C.; TITTONI, J. A psicologia social e o trabalho em comunidades: Limites e possibilidades. Revista Internacional de Psicologia, v.40, n.1, p.51-58, 2006.

SILVA, E.R.A. Participação Social e as conferências nacionais de políticas públicas: reflexões sobre os avanços e desafios no período de 2003-06. Brasília: IPEA, 2009.

SILVA, R.C. De Abaiara a Bissau: por uma (e) Educação com adolescentes, sem a adolescência. 2011. Tese (Doutorado em Educação) - Faculdade de Educação, Universidade de Campinas, Campinas, 2011. Disponível em: < http://www.bibliotecadigital.unicamp.br/document/?code=vtls000437952>. Acesso em: 15 de jun.2014.

SILVA, T.T. Teoria cultural e educação: um vocabulário crítico. Belo Horizonte: Autêntica, 2000.

SILVA, T.T. Nunca fomos humanos: nos rastros do sujeito. Belo Horizonte: Autêntica, 2001, 208 p.

SILVA, T.T. Documentos de identidade: uma introdução às teorias do currículo. Belo Horizonte: Autêntica, 2005, 156 p.

SILVA, T.T.. Identidade e diferença uma introdução teórica e conceitual. SILVA, T.T.(Org.). Identidade e diferença: a perspectiva dos estudos culturais. Petrópolis: Vozes, 2007, 133 p.

SILVA, Rosane N. A dobra deleuziana: políticas de subjetivação. Revista do Departamento de Psicologia (UFF), Niterói, v. 16, n.1, p. 55-75, 2004.

SOUZA, R. M. O discurso do protagonismo juvenil. 2006. 350f. Tese (Doutorado em Sociologia) - Departamento de Sociologia, Faculdade de Filosofia, Letras e Ciências Humanas, Universidade de São Paulo, 2006.

SOUZA, P. L. A. A participação nas políticas públicas de juventude: caminhos trilhados, caminhos a construir. In: Papa, F. C.; FREITAS, M.V.(Orgs.). Juventude em pauta: políticas públicas no Brasil. São Paulo: Peirópolis, 2011. 
SOUZA, C. H. L. ; CRUXEN, I. ; LIMA, P. P. F. ; ALENCAR, J. ; RIBEIRO, U. . Conferências típicas e atípicas: um esforço de caracterização do fenômeno político. In: Leonardo Avritzer, Clóvis Henrique Leite de Souza. (Org.). Conferências nacionais: atores, dinâmicas participativas e efetividades. 1ed.Brasília: Ipea, 2013 , v. 1 , p. $25-52$.

TAKEUTI, N. M. Dobras na juventude e nomadismo. Latitude, Alfenas-MG, v. 6, n. 1, p. 7-23, 2012. Disponível em: < http://www.seer.ufal.br/index.php/latitude/article/view/851>. Acesso: 10 de ago.2015a.

TAKEUTI, N. M. Paradoxos societais e juventude contemporânea. Estudos de Psicologia, Natal, v. 17, n. 3, p. 427-434, set./dez., 2012b.

TRAGTENBERG, M. Apresentação. In: GUIMARÃES, A.M. Vigilância, Punição e Depredação Escolar Campinas, SP: Papirus, 2003.

UNESCO. Políticas de/para/com juventudes. Brasília:UNESCO, 2004.

VALADARES, M.G.P.F. Participação nas redes sociotécnicas: potência e controle. Mediação, Belo Horizonte, v.11, n.10, jan-jun.2010.

VARGAS, E.V. Gabriel Tarde e a diferença infinitesimal. In: TARDE, G.; VARGAS, E.V. (Org.). Monodologia e sociologia e outros ensaios. São Paulo: Cosacnaify, 2007, p.7-39.

VEIGA-NETO, A. Incluir para excluir. IN: LARROSA, J.; SKLIAR, C. (Orgs).

Habitantes de Babel políticas e poéticas da diferença. 2.ed. Belo Horizonte: Autêntica, 2011. p. 105-118.

VEIGA-NETO, A.Olhares...In: COSTA, M.V. (Org.). Caminhos Investigativos: novos olhares na pesquisa em educação. Porto Alegre: Mediação, 1996, p.19-36.

VEIGA-NETO, A. O sujeito. In: VEIGA-NETO, A. Foucault \& a educação. Belo Horizonte: Autêntica Editora, 2014, p. 107-114.

VEIGA-NETO, A. As idade do corpo: (material)idades, (divers)idades, (corporal)idades, (ident)idades...2000. (não paginado) Disponível em: < http://www.lite.fe.unicamp.br/cursos/nt/ta5.12.htm Acesso em: 14 de abr. 2015.

VIANNA, M.L.T. W.; CAVALCANTI, M.L.; CABRAL, M.P. Participação em saúde: do que estamos falando? Sociologias, Porto Alegre, n.21, jan-jun, p.218-251, 2009.

WENDAHAUSEN, A; CARDOSO, S. M. Processo decisório e Conselhos Gestores de Saúde: aproximações teóricas. Revista Brasileira de Enfermagem, Brasília, v. 60, n.5, p.579-584, 2007.

WENDHAUSEN, A; CAPONI, S. O diálogo e a participação em um conselho de saúde em Santa Catarina, Brasil. Caderno de Saúde Pública, Rio de Janeiro, v.18, n. 6, nov-dez, 2002. 
WOODWARD, K. Identidade e diferença: uma introdução teórica e conceitural. In: SILVA, T.T. (Org.). Identidade e diferença: a perspectiva dos estudos culturais. Petrópolis: Vozes, 2007, p.7-72 p. 


\section{APÊNDICE A - MODELO DO TERMO DE CONSENTIMENTO LIVRE E ESCLARECIDO}

\section{$\mathrm{EACH} \mid$}

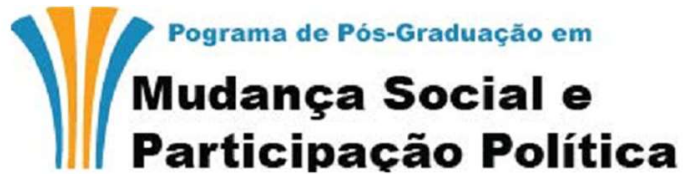

\section{TERMO DE CONSENTIMENTO LIVRE E ESCLARECIDO}

Título do Projeto: O que a rebeldia teima? Capturas e resistências das juventudes nas conferências.

Pesquisador Responsável: Rodrigo Crivelaro

\section{Este projeto tem o objetivo:}

- conhecer e problematizar os discursos de jovens de Santa Bárbara d'Oeste sobre as conferências de juventude e as políticas públicas de juventude no município.

\section{Para tanto será necessário realizar os seguintes procedimentos:}

- entrevista com jovens participantes das conferências de juventude que aconteceram no município nos anos de 2008, 2011, 2014 e 2015.

- análise das entrevistas e de documentos produzidos nas Conferências de Juventude em Santa Bárbara d'Oeste - SP

Durante a execução da entrevista caso sinta-se desconfortável para responder a alguma pergunta, você pode não respondê-la ou solicitar o encerramento deste procedimento.

A participação no estudo não acarretará custos para você e não será disponível nenhuma compensação financeira.

Por tratar-se de uma pesquisa que utiliza a fala como forma de produção de dados, apresenta riscos mínimos a saúde.

Após ler e receber explicações sobre a pesquisa, e ter meus direitos de:

1. receber resposta a qualquer pergunta e esclarecimento sobre os procedimentos, riscos, benefícios e outros relacionados à pesquisa;

2. retirar o consentimento a qualquer momento e deixar de participar do estudo;

3. não ser identificado e ser mantido o caráter confidencial das informações relacionadas à privacidade.

4. procurar esclarecimentos com o Comitê de Ética em Pesquisa da Escola de Artes, Ciências e Humanidades (EACH) da Universidade de São Paulo(USP) através do telefone (11) 3091-1046 ou por e-mail cep-each@usp.br, em caso de dúvidas ou notificação de acontecimentos não previstos.

Declaro estar ciente do exposto e desejar participar da projeto da pesquisa. 
$\mathrm{Eu}$, fui informada (o) dos objetivos da pesquisa acima de maneira clara e detalhada e esclareci minhas dúvidas. Sei que em qualquer momento poderei solicitar novas informações e motivar minha decisão se assim o desejar. O pesquisador Rodrigo Crivelaro certificou-me de que todos os dados desta pesquisa serão confidenciais.

Em caso de dúvidas poderei contatar o estudante Rodrigo Crivelaro, sua professora orientadora Elizabete Franco Cruz pelo e-mail betefranco@usp.br ou o Comitê de Ética em Pesquisa da Escola de Artes, Ciências e Humanidades (EACH) da Universidade de São Paulo(USP) através do telefone (11) 3091-1046 ou por e-mail cep-each@usp.br.

Declaro que concordo em participar desse estudo. Recebi uma cópia deste termo de consentimento livre e esclarecido e me foi dada a oportunidade de ler e esclarecer as minhas dúvidas.

Caso tenha interesse em saber os resultados desta pesquisa você pode entrar em contato com o pesquisador acima mencionado pelo e-mail rodrigo.crivelaro@usp.br ou pelos telefones (19) 99980-7887 ou 99146-7887.

Santa Bárbara d'Oeste - SP, de de 2015.

Nome do sujeito/ ou do responsável:

Assinatura:

Eu, Rodrigo Crivelaro, declaro que forneci todas as informações referentes ao projeto ao participante e/ou responsável.

Telefone : (19) 99980-7887 ou 99146-7887

Data: 


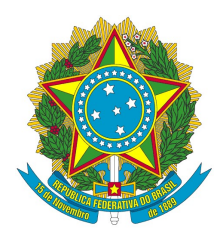

\section{Presidência da República Casa Civil Subchefia para Assuntos Jurídicos}

\section{DECRETO № 8.243, DE 23 DE MAIO DE 2014}

Institui a Política Nacional de Participação Social PNPS e o Sistema Nacional de Participação Social SNPS, e dá outras providências.

A PRESIDENTA DA REPÚBLICA, no uso das atribuições que the confere o art. 84, caput, incisos IV e VI, alínea "a", da Constituição, e tendo em vista o disposto no art. 3으, caput, inciso I, e no art. 17 da Lei no 10.683 , de 28 de maio de 2003,

\section{DECRETA:}

Art. 10 Fica instituída a Política Nacional de Participação Social - PNPS, com o objetivo de fortalecer e articular os mecanismos e as instâncias democráticas de diálogo e a atuação conjunta entre a administração pública federal e a sociedade civil.

Parágrafo único. Na formulação, na execução, no monitoramento e na avaliação de programas e políticas públicas e no aprimoramento da gestão pública serão considerados os objetivos e as diretrizes da PNPS.

Art. 2 Para os fins deste Decreto, considera-se:

I - sociedade civil - o cidadão, os coletivos, os movimentos sociais institucionalizados ou não institucionalizados, suas redes e suas organizações;

II - conselho de políticas públicas - instância colegiada temática permanente, instituída por ato normativo, de diálogo entre a sociedade civil e o governo para promover a participação no processo decisório e na gestão de políticas públicas;

III - comissão de políticas públicas - instância colegiada temática, instituída por ato normativo, criada para o diálogo entre a sociedade civil e o governo em torno de objetivo específico, com prazo de funcionamento vinculado ao cumprimento de suas finalidades;

IV - conferência nacional - instância periódica de debate, de formulação e de avaliação sobre temas específicos e de interesse público, com a participação de representantes do governo e da sociedade civil, podendo contemplar etapas estaduais, distrital, municipais ou regionais, para propor diretrizes e ações acerca do tema tratado;

V - ouvidoria pública federal - instância de controle e participação social responsável pelo tratamento das reclamações, solicitações, denúncias, sugestões e elogios relativos às políticas e aos serviços públicos, prestados sob qualquer forma ou regime, com vistas ao aprimoramento da gestão pública;

VI - mesa de diálogo - mecanismo de debate e de negociação com a participação dos setores da sociedade civil e do governo diretamente envolvidos no intuito de prevenir, mediar e solucionar conflitos sociais;

VII - fórum interconselhos - mecanismo para o diálogo entre representantes dos conselhos e comissões de políticas públicas, no intuito de acompanhar as políticas públicas e os programas governamentais, formulando recomendações para aprimorar sua intersetorialidade e transversalidade;

VIII - audiência pública - mecanismo participativo de caráter presencial, consultivo, aberto a qualquer interessado, com a possibilidade de manifestação oral dos participantes, cujo objetivo é subsidiar decisões governamentais;

IX - consulta pública - mecanismo participativo, a se realizar em prazo definido, de caráter consultivo, aberto a qualquer interessado, que visa a receber contribuições por escrito da sociedade civil sobre determinado assunto, na forma definida no seu ato de convocação; e

$X$ - ambiente virtual de participação social - mecanismo de interação social que utiliza tecnologias de informação e de comunicação, em especial a internet, para promover o diálogo entre administração pública federal e sociedade civil. 
Parágrafo único. As definições previstas neste Decreto não implicam na desconstituição ou alteração de conselhos, comissões e demais instâncias de participação social já instituídos no âmbito do governo federal.

Art. 3ำ São diretrizes gerais da PNPS:

I - reconhecimento da participação social como direito do cidadão e expressão de sua autonomia;

II - complementariedade, transversalidade e integração entre mecanismos e instâncias da democracia representativa, participativa e direta;

III - solidariedade, cooperação e respeito à diversidade de etnia, raça, cultura, geração, origem, sexo, orientação sexual, religião e condição social, econômica ou de deficiência, para a construção de valores de cidadania e de inclusão social;

IV - direito à informação, à transparência e ao controle social nas ações públicas, com uso de linguagem simples e objetiva, consideradas as características e o idioma da população a que se dirige;

V - valorização da educação para a cidadania ativa;

VI - autonomia, livre funcionamento e independência das organizações da sociedade civil; e

VII - ampliação dos mecanismos de controle social.

Art. 4ํ São objetivos da PNPS, entre outros:

I - consolidar a participação social como método de governo;

II - promover a articulação das instâncias e dos mecanismos de participação social;

III - aprimorar a relação do governo federal com a sociedade civil, respeitando a autonomia das partes;

IV - promover e consolidar a adoção de mecanismos de participação social nas políticas e programas de governo federal;

V - desenvolver mecanismos de participação social nas etapas do ciclo de planejamento e orçamento;

$\mathrm{VI}$ - incentivar o uso e o desenvolvimento de metodologias que incorporem múltiplas formas de expressão e linguagens de participação social, por meio da internet, com a adoção de tecnologias livres de comunicação e informação, especialmente, softwares e aplicações, tais como códigos fonte livres e auditáveis, ou os disponíveis no Portal do Software Público Brasileiro;

VII - desenvolver mecanismos de participação social acessíveis aos grupos sociais historicamente excluídos e aos vulneráveis;

VIII - incentivar e promover ações e programas de apoio institucional, formação e qualificação em participação social para agentes públicos e sociedade civil; e

IX - incentivar a participação social nos entes federados.

Art. 5o Os órgãos e entidades da administração pública federal direta e indireta deverão, respeitadas as especificidades de cada caso, considerar as instâncias e os mecanismos de participação social, previstos neste Decreto, para a formulação, a execução, o monitoramento e a avaliação de seus programas e políticas públicas.

$\S 10$ Os órgãos e entidades referidos no caput elaborarão, anualmente, relatório de implementação da PNPS no âmbito de seus programas e políticas setoriais, observadas as orientações da Secretaria-Geral da Presidência da República.

§ 2으 A Secretaria-Geral da Presidência da República elaborará e publicará anualmente relatório de avaliação da implementação da PNPS no âmbito da administração pública federal.

Art. 6으 São instâncias e mecanismos de participação social, sem prejuízo da criação e do reconhecimento de outras formas de diálogo entre administração pública federal e sociedade civil:

I - conselho de políticas públicas;

II - comissão de políticas públicas;

III - conferência nacional;

IV - ouvidoria pública federal;

$\mathrm{V}$ - mesa de diálogo;

VI - fórum interconselhos;

VII - audiência pública;

VIII - consulta pública; e

IX - ambiente virtual de participação social.

Art. 70 O Sistema Nacional de Participação Social - SNPS, coordenado pela Secretaria-Geral da Presidência da República, será integrado pelas instâncias de participação social previstas nos incisos I a IV do art. 60 deste Decreto, sem prejuízo da integração de outras formas de diálogo entre a administração pública federal e a sociedade civil.

Parágrafo único. A Secretaria-Geral da Presidência da República publicará a relação e a respectiva composição das instâncias integrantes do SNPS.

Art. 8으 Compete à Secretaria-Geral da Presidência da República: 
I - acompanhar a implementação da PNPS nos órgãos e entidades da administração pública federal direta e indireta;

II - orientar a implementação da PNPS e do SNPS nos órgãos e entidades da administração pública federal direta e indireta;

III - realizar estudos técnicos e promover avaliações e sistematizações das instâncias e dos mecanismos de participação social definidos neste Decreto;

IV - realizar audiências e consultas públicas sobre aspectos relevantes para a gestão da PNPS e do SNPS; e

$\mathrm{V}$ - propor pactos para o fortalecimento da participação social aos demais entes da federação.

Art. 9o Fica instituído o Comitê Governamental de Participação Social - CGPS, para assessorar a Secretaria-Geral da Presidência da República no monitoramento e na implementação da PNPS e na coordenação do SNPS.

§ 1ํㅡ CGPS será coordenado pela Secretaria-Geral da Presidência da República, que dará o suporte técnico-administrativo para seu funcionamento.

§ 2으 Ato do Ministro de Estado Chefe da Secretaria-Geral da Presidência da República disporá sobre seu funcionamento.

Art.10. Ressalvado o disposto em lei, na constituição de novos conselhos de políticas públicas e na reorganização dos já constituídos devem ser observadas, no mínimo, as seguintes diretrizes:

I - presença de representantes eleitos ou indicados pela sociedade civil, preferencialmente de forma paritária em relação aos representantes governamentais, quando a natureza da representação o recomendar; natureza;

II - definição, com consulta prévia à sociedade civil, de suas atribuições, competências e

III - garantia da diversidade entre os representantes da sociedade civil;

IV - estabelecimento de critérios transparentes de escolha de seus membros;

$\mathrm{V}$ - rotatividade dos representantes da sociedade civil;

$\mathrm{VI}$ - compromisso com o acompanhamento dos processos conferenciais relativos ao tema de sua competência; e

VII - publicidade de seus atos.

§ 1으 A participação dos membros no conselho é considerada prestação de serviço público relevante, não remunerada.

§ 2ㅇ A publicação das resoluções de caráter normativo dos conselhos de natureza deliberativa vincula-se à análise de legalidade do ato pelo órgão jurídico competente, em acordo com o disposto na Lei Complementar nำ7, de 10 de fevereiro de 1993.

$\S 3$ ㅇ A rotatividade das entidades e de seus representantes nos conselhos de políticas públicas deve ser assegurada mediante a recondução limitada a lapso temporal determinado na forma dos seus regimentos internos, sendo vedadas três reconduções consecutivas.

§ 4ㅇ A participação de dirigente ou membro de organização da sociedade civil que atue em conselho de política pública não configura impedimento à celebração de parceria com a administração pública.

§ 5o $\mathrm{Na}$ hipótese de parceira que envolva transferência de recursos financeiros de dotações consignadas no fundo do respectivo conselho, o conselheiro ligado à organização que pleiteia o acesso ao recurso fica impedido de votar nos itens de pauta que tenham referência com o processo de seleção, monitoramento e avaliação da parceria. diretrizes:

Art. 11. Nas comissões de políticas públicas devem ser observadas, no mínimo, as seguintes

I - presença de representantes eleitos ou indicados pela sociedade civil;

II - definição de prazo, tema e objetivo a ser atingido;

III - garantia da diversidade entre os representantes da sociedade civil;

IV - estabelecimento de critérios transparentes de escolha de seus membros; e

$\mathrm{V}$ - publicidade de seus atos.

Art. 12. As conferências nacionais devem observar, no mínimo, as seguintes diretrizes:

I - divulgação ampla e prévia do documento convocatório, especificando seus objetivos e etapas;

II - garantia da diversidade dos sujeitos participantes;

III - estabelecimento de critérios e procedimentos para a designação dos delegados governamentais e para a escolha dos delegados da sociedade civil;

IV - integração entre etapas municipais, estaduais, regionais, distrital e nacional, quando houver;

V - disponibilização prévia dos documentos de referência e materiais a serem apreciados na etapa nacional; 

etapas;

VI - definição dos procedimentos metodológicos e pedagógicos a serem adotados nas diferentes

VII - publicidade de seus resultados;

VIII - determinação do modelo de acompanhamento de suas resoluções; e

IX - indicação da periodicidade de sua realização, considerando o calendário de outros processos conferenciais.

Parágrafo único. As conferências nacionais serão convocadas por ato normativo específico, ouvido o CGPS sobre a pertinência de sua realização.

Art. 13. As ouvidorias devem observar as diretrizes da Ouvidoria-Geral da União da Controladoria-Geral da União nos termos do art. 14, caput, inciso I, do Anexo I ao Decreto nํㅜ 8.109, de 17 de setembro de 2013.

Art. 14. As mesas de diálogo devem observar, no mínimo, as seguintes diretrizes:

I - participação das partes afetadas;

II - envolvimento dos representantes da sociedade civil na construção da solução do conflito;

III - prazo definido de funcionamento; e

IV - acompanhamento da implementação das soluções pactuadas e obrigações voluntariamente assumidas pelas partes envolvidas.

Parágrafo único. As mesas de diálogo criadas para o aperfeiçoamento das condições e relações de trabalho deverão, preferencialmente, ter natureza tripartite, de maneira a envolver representantes dos empregados, dos empregadores e do governo.

Art. 15. Os fóruns interconselhos devem observar, no mínimo, as seguintes diretrizes:

I - definição da política ou programa a ser objeto de debate, formulação e acompanhamento;

II - definição dos conselhos e organizações da sociedade civil a serem convidados pela sua vinculação ao tema;

III - produção de recomendações para as políticas e programas em questão; e

IV - publicidade das conclusões.

Art. 16. As audiências públicas devem observar, no mínimo, as seguintes diretrizes:

I - divulgação ampla e prévia do documento convocatório, especificado seu objeto, metodologia e o momento de realização;

II - livre acesso aos sujeitos afetados e interessados;

III - sistematização das contribuições recebidas;

IV - publicidade, com ampla divulgação de seus resultados, e a disponibilização do conteúdo dos debates; e

$\mathrm{V}$ - compromisso de resposta às propostas recebidas.

Art. 17. As consultas públicas devem observar, no mínimo, as seguintes diretrizes:

I - divulgação ampla e prévia do documento convocatório, especificando seu objeto, metodologia e o momento de realização;

II - disponibilização prévia e em tempo hábil dos documentos que serão objeto da consulta em linguagem simples e objetiva, e dos estudos e do material técnico utilizado como fundamento para a proposta colocada em consulta pública e a análise de impacto regulatório, quando houver;

III - utilização da internet e de tecnologias de comunicação e informação;

IV - sistematização das contribuições recebidas;

$\mathrm{V}$ - publicidade de seus resultados; e

$\mathrm{VI}$ - compromisso de resposta às propostas recebidas.

Art. 18. Na criação de ambientes virtuais de participação social devem ser observadas, no mínimo, as seguintes diretrizes:

I - promoção da participação de forma direta da sociedade civil nos debates e decisões do governo;

II - fornecimento às pessoas com deficiência de todas as informações destinadas ao público em geral em formatos acessíveis e tecnologias apropriadas aos diferentes tipos de deficiência;

III - disponibilização de acesso aos termos de uso do ambiente no momento do cadastro;

IV - explicitação de objetivos, metodologias e produtos esperados;

$\mathrm{V}$ - garantia da diversidade dos sujeitos participantes;

VI - definição de estratégias de comunicação e mobilização, e disponibilização de subsídios para o diálogo;

VII - utilização de ambientes e ferramentas de redes sociais, quando for o caso;

VIII - priorização da exportação de dados em formatos abertos e legíveis por máquinas;

IX - sistematização e publicidade das contribuições recebidas;

X - utilização prioritária de softwares e licenças livres como estratégia de estímulo à participação na construção das ferramentas tecnológicas de participação social; e 
XI - fomento à integração com instâncias e mecanismos presenciais, como transmissão de debates e oferta de oportunidade para participação remota.

Art. 19. Fica instituída a Mesa de Monitoramento das Demandas Sociais, instância colegiada interministerial responsável pela coordenação e encaminhamento de pautas dos movimentos sociais e pelo monitoramento de suas respostas.

$\S 1$ 을 As reuniões da Mesa de Monitoramento serão convocadas pela Secretaria-Geral da Presidência da República, sendo convidados os Secretários-Executivos dos ministérios relacionados aos temas a serem debatidos na ocasião.

$\S 2$ ㅇ Ato do Ministro de Estado Chefe da Secretaria-Geral da Presidência da República disporá sobre as competências específicas, o funcionamento e a criação de subgrupos da instância prevista no caput.

Art. 20. As agências reguladoras observarão, na realização de audiências e consultas públicas, o disposto neste Decreto, no que couber.

Art. 21. Compete à Casa Civil da Presidência da República decidir sobre a ampla divulgação de projeto de ato normativo de especial significado político ou social nos termos do art. 34, caput, inciso II, do Decreto no 4.176 , de 28 de março de 2002.

Art. 22. Este Decreto entra em vigor na data de sua publicação.

Brasília, 23 de maio de 2014; 193으 da Independência e 1260 da República.

DILMA ROUSSEFF

Miriam Belchior

Gilberto Carvalho

Jorge Hage Sobrinho

Este texto não substitui o publicado no DOU de 26.5.2014

BRASIL. Decreto n. ${ }^{\circ} 8243$, de 23 de maio de 2014. Institui a Política Nacional de Participação Social - PNPS e o Sistema Nacional de Participação Social - SNPS, e dá outras providências. Disponível em:

<http://www.planalto.gov.br/ccivil_03/_Ato2011-2014/2014/Decreto/D8243.htm.>. Acesso em: 30 jun.2014. 
ANEXO B - PDC N. ${ }^{0} 1491 / 2014$

\section{CÂMARA DOS DEPUTADOS}

PROJETO DE DECRETO LEGISLATIVO № ， DE 2014

(Dos Srs. Mendonça Filho e Ronaldo Caiado)

Susta a aplicação do Decreto $n^{\circ} 8.243$, de 23 de maio de 2014, que institui a Política Nacional de Participação Social - PNPS e o Sistema Nacional de Participação Social - SNPS, e dá outras providências.

O CONGRESSO NACIONAL decreta:

Art. $1^{\circ}$. Nos termos do art. 49 , inciso $\mathrm{V}$, da Constituição Federal, fica sustado o Decreto $n^{0} 8.243$, de 23 de maio de 2014, que institui a Política Nacional de Participação Social - PNPS e o Sistema Nacional de Participação Social - SNPS, e dá outras providências.

Art. $2^{\circ}$. Este Decreto Legislativo entra em vigor na data de sua publicação.

\section{JUSTIFICATIVA}

O Decreto presidencial $n^{0} 8.243$, de 23 de maio de 2014 , institui a Política Nacional de Participação Social - PNPS e o Sistema Nacional de Participação Social - SNPS, e dá outras providências.

Em detida análise da matéria, percebe-se a ostensiva e flagrante inconstitucionalidade do ato normativo que ora se pretende impugnar. 


\section{CÂMARA DOS DEPUTADOS}

O Decreto presidencial corrói as entranhas do regime representativo, um dos pilares do Estado democrático de direito, adotado legitimamente na Constituição Federal de 1988.

Vejamos.

No art. $1^{\circ}$, dispõe que "fica instituída a Política Nacional de Participação Social - PNPS, com o objetivo de fortalecer e articular os mecanismos e as instâncias democráticas de diálogo e a atuação conjunta entre a administração pública federal e a sociedade civil". No art. $2^{\circ}$, estabelece o que é sociedade civil e no art. $3^{\circ}$ reconhece a participação social como direito do cidadão e expressão de sua autonomia e - pasmem - reconhece que se trata da ampliação dos mecanismos de controle social. No art. $4^{\circ}$, inc. VIII, afirma ser objetivo da Política incentivar e promover ações e programas de apoio institucional, formação e qualificação em participação social para agentes públicos e sociedade civil.

Nesta primeira etapa, resta patente a prevalência do direito à participação daqueles considerados pelo Governo como sociedade civil ou movimentos sociais, com incentivo à sua formação. $O$ cidadão comum, não afeto a este ativismo social, fica relegado ao segundo plano dentro da organização política prevista no referido Decreto.

O art. $5^{\circ}$ determina que "os órgãos e entidades da administração pública federal direta e indireta deverão, respeitadas as especificidades de cada caso, considerar as instâncias e os mecanismos de participação social, previstos neste Decreto, para a formulação, a execução, o monitoramento e a avaliação de seus programas e políticas públicas", sendo que sua implantação será acompanhada pela Secretaria Geral da Presidência da República.

Neste ponto, cumpre ressaltar os riscos aos quais as políticas públicas passam a se submeter, ante a necessária oitiva das decisões tomadas no âmbito do aberrante "sistema de participação social", de que trata $\circ$ ato questionado. 


\section{CÂMARA DOS DEPUTADOS}

Essas breves linhas retratam de maneira absolutamente clara qual a intenção da Presidente da República: implodir o regime de democracia representativa, na medida em que tende a transformar esta Casa em um autêntico elefante branco, mediante a transferência do debate institucional para segmentos eventualmente cooptados pelo próprio Governo. $O$ ato em questão não comporta outra leitura. Especialmente, levando-se em conta que a Carta da República já disponibiliza os instrumentos que asseguram a participação de qualquer cidadão brasileiro nas decisões políticas.

$\mathrm{Na}$ verdade, sob o manto de se aumentar a participação popular, o que o Governo faz é restringir esta participação àquele segmento social escolhido de acordo com a cartilha palaciana, impedindo o acesso amplo e irrestrito de todo cidadão, garantido, entre outros dispositivos, pelo art. 14 da Carta Magna, que reza: "A soberania popular será exercida pelo sufrágio universal, e pelo voto direto e secreto, com valor igual para todos e nos termos da lei, mediante: Iplebiscito; II - referendo; III - iniciativa popular.".

Ao dar prerrogativas aos movimentos sociais adeptos da ideologia do grupo político no poder nos últimos doze anos e fomentar a sua ampliação; ao submeter os órgãos da Administração Pública - incluindo as agências reguladoras - às decisões tomadas no âmbito do Programa; e ao promover o controle dos movimentos sociais, a Presidente da República, na verdade, está criando seu próprio Estado, suas próprias regras, suas classes de cidadãos, incorporando, assim, a figura de Luis XIV, quando disse: L'Etat c'est moi.

A necessidade de se combater esta insanidade consolidada no Decreto $\mathrm{n}^{0} 8.243$, de 23 de maio de 2014, também se revela no absurdo cenário que estamos vivendo no Brasil. Tentativas de controlar a mídia através de mecanismos de regulação econômica e de conteúdo, o inchaço da máquina pública (p.ex.40 ministérios!!!), aparelhamento do Estado, através da colocação de quadros políticos em cargos técnicos chave (como se viu nos recentes escândalos da Petrobrás), a tentativa de controle do Poder Legislativo, com a impressionante edição de medidas provisórias e urgências constitucionais etc. 
Todos estes aspectos demonstram como se faz urgente e indispensável o combate a toda e qualquer tentativa de subversão da ordem constitucional posta, uma vez que a sanha autoritária da Presidente da República apenas aguarda o instante para se revelar e assumir o seu lugar.

Nesses termos, uma vez demonstrada a exorbitância do ato normativo ora combatido, solicitamos, com base no art. 49, V, da Constituição da República, o apoio dos nobres Pares no sentido de sustar a referida norma.

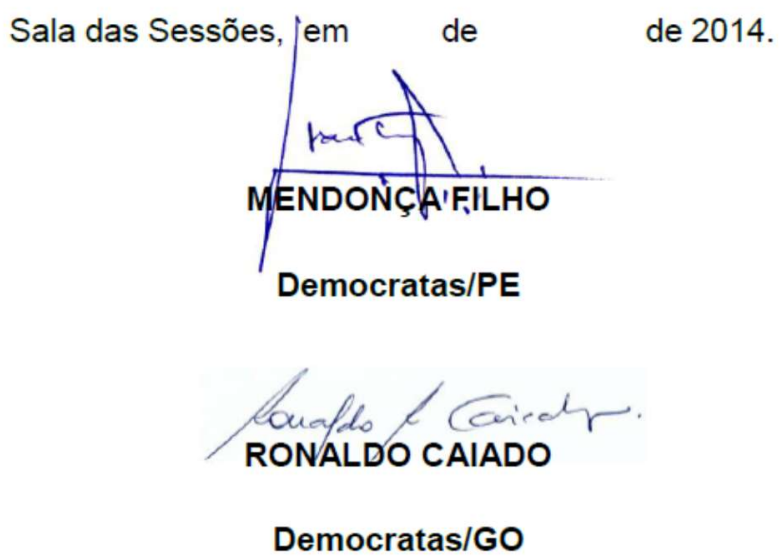

BRASIL. Congresso. Câmara dos Deputados. Projeto de Decreto Legislativo n. ${ }^{\circ}$ 1491/2015. Susta a aplicação do Decreto n. ${ }^{\circ} 8243$, de 23 de maio de 2014, que institui a Política Nacional de Participação Social - PNPS e o Sistema Nacional de Participação Social - SNPS, e dá outras providências. Disponível em: < http://www.camara.gov.br/proposicoesWeb/fichadetramitacao?idProposicao=617737 >. Acesso em: 10 dez. 2015. 


\section{SENADO FEDERAL PROJETO DE DECRETO LEGISLATIVO № 147, DE 2014}

(№ 1.491/2014, na Câmara dos Deputados, dos Deputados Mendonça Filho e Ronaldo Caiado)

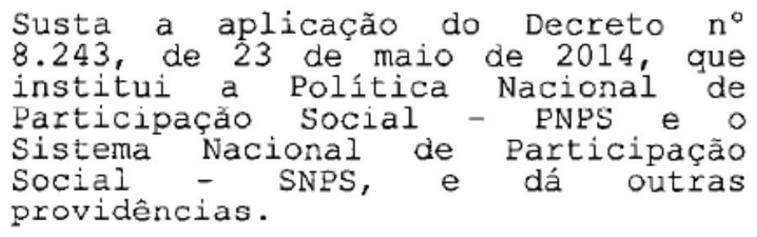

O CONGRESSO NACIONAL decreta:

Art. $1^{\circ}$ Nos termos do inciso $V$ do art. 49 da

Constituição Federal, fica sustado o Decreto $n^{\circ} 8.243$, de 23 de maio de 2014, que institui a Política Nacional de Participação Social - PNPS e o Sistema Nacional de Participação Social - SNPS, e dá outras providências.

Art, $2^{\circ}$ Este Decreto Legislativo entra em vigor na data de sua publicação.

BRASIL. Congresso. Senado. Projeto de Decreto Legislativo n. ${ }^{\circ} 147$, de 3 de novembro de 2014. Susta a aplicação do Decreto n. ${ }^{\circ} 8243$, de 23 de maio de 2014, que institui a Política Nacional de Participação Social - PNPS e o Sistema Nacional de Participação Social - SNPS, e dá outras providências. Disponível em:

<http://www25.senado.leg.br/web/atividade/materias/-/materia/118766.> Acesso em: 10 dez.2015. 


\section{ANEXO D - CARTILHA PNPS}

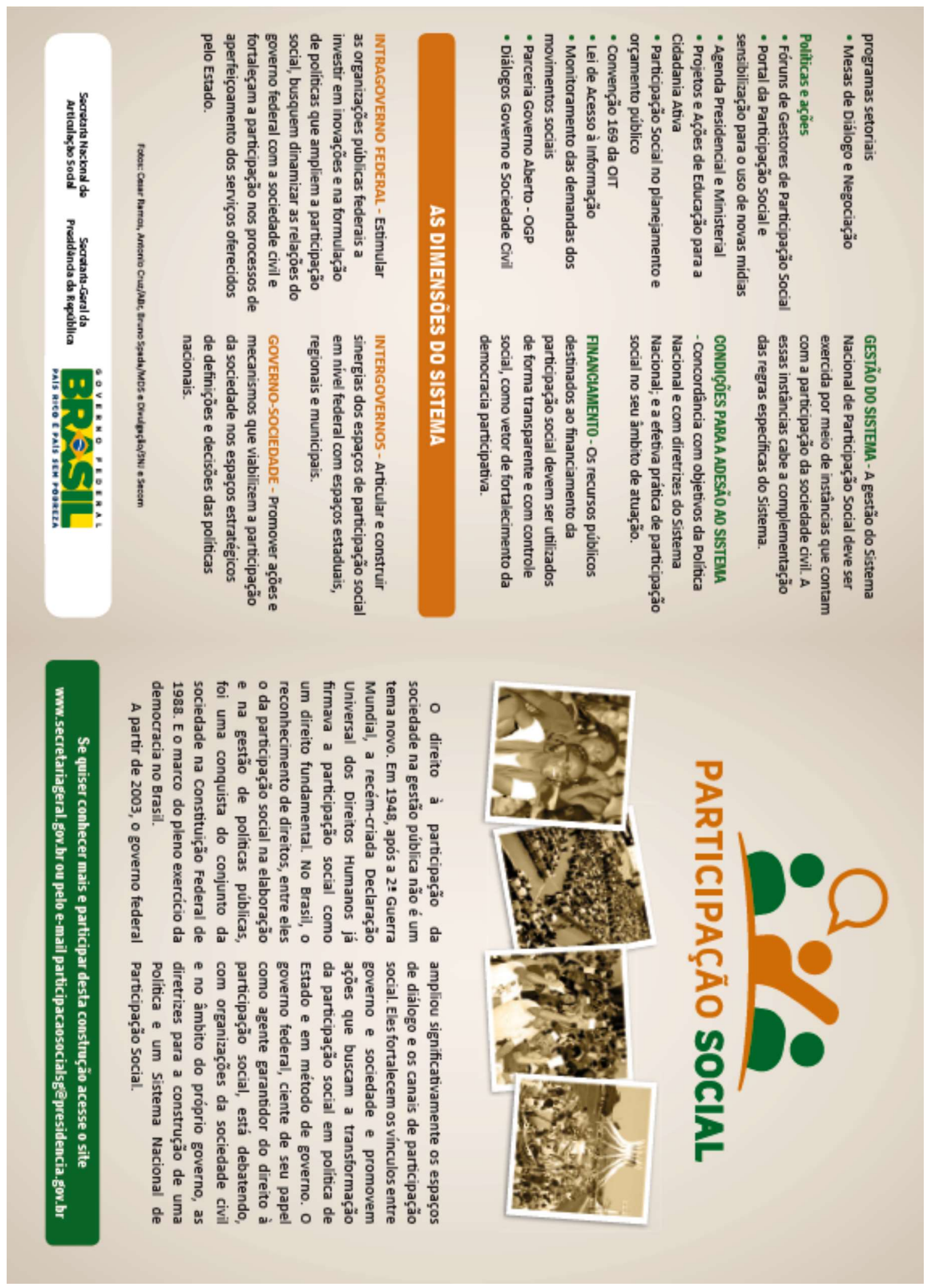



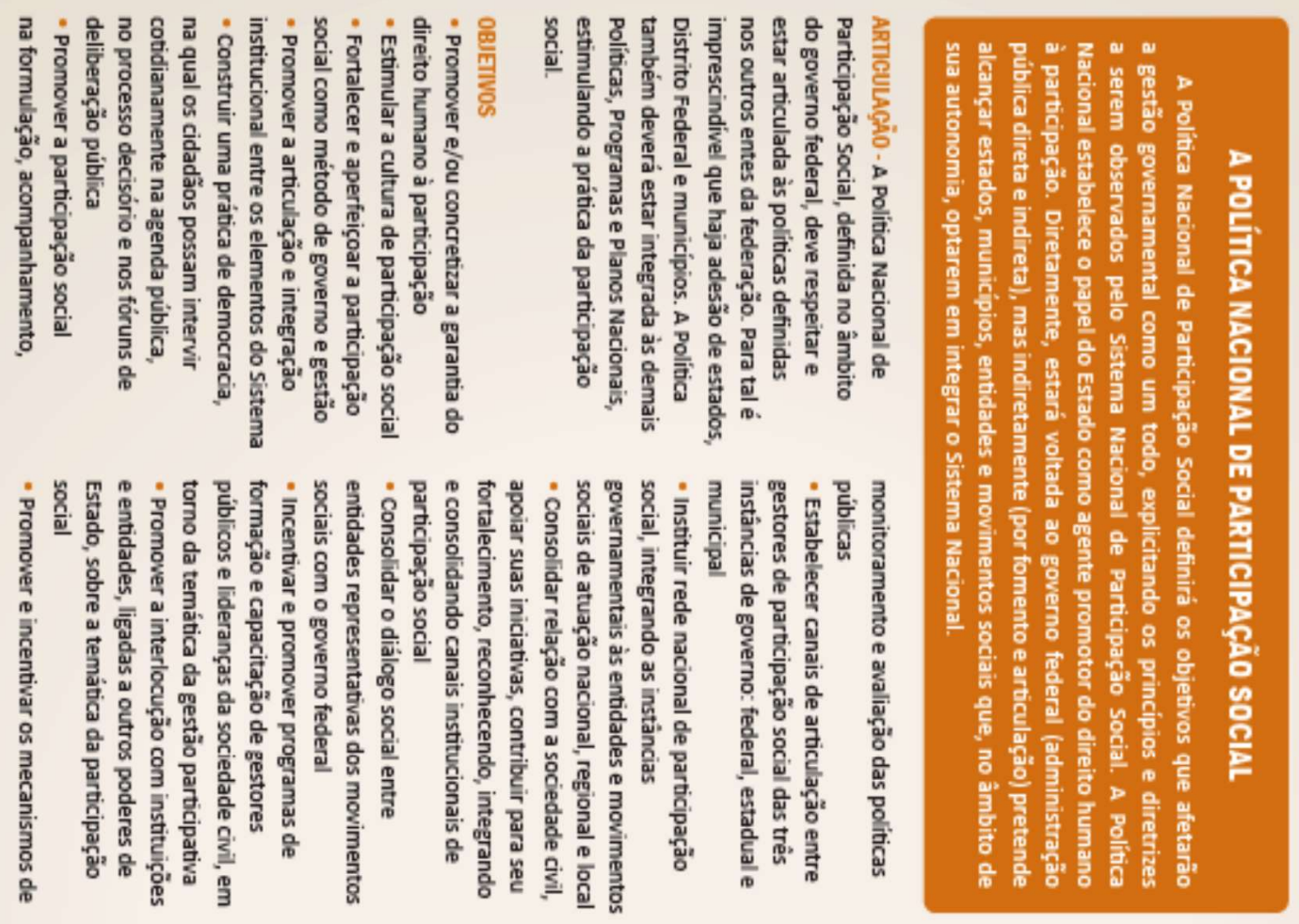
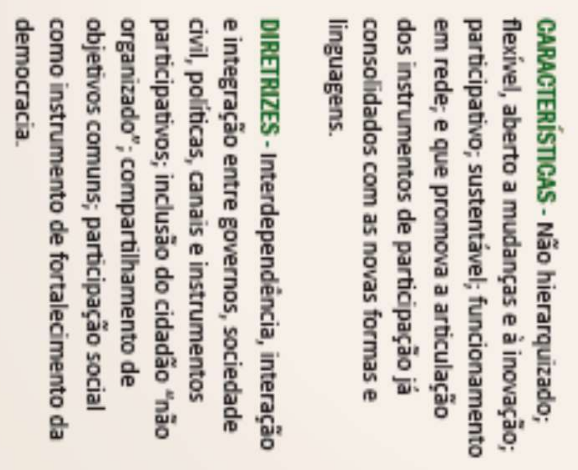

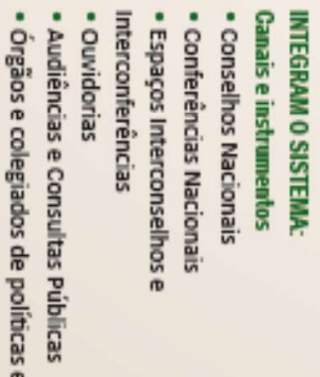
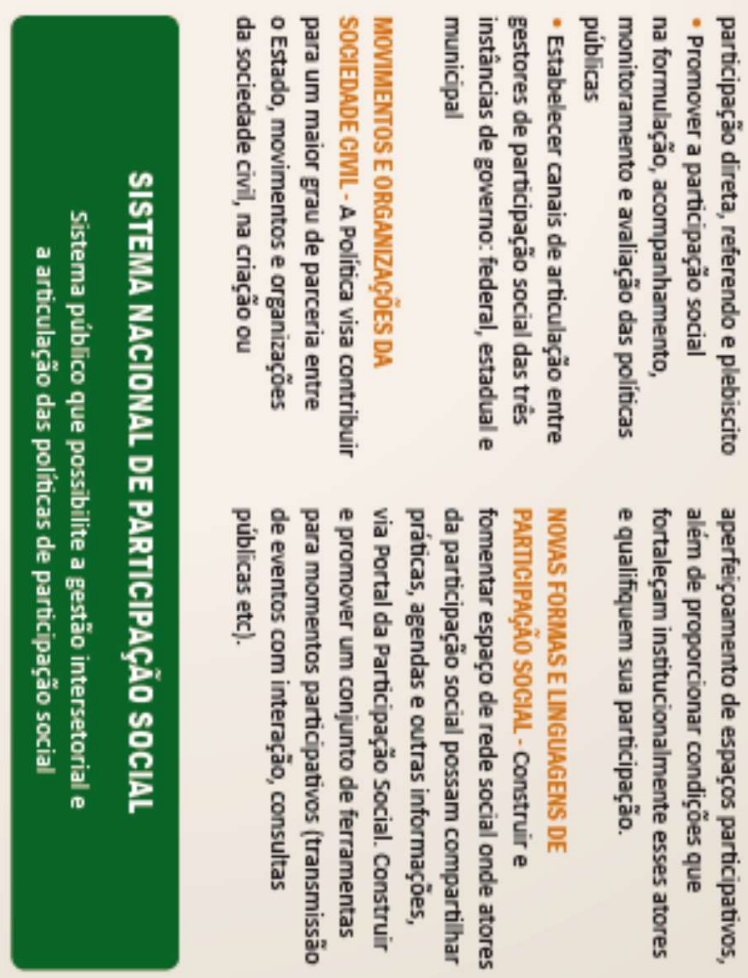

BRASIL. Secretaria-Geral da Presidência da República. Participação Social. Disponível em: < http://www.secretariageral.gov.br/art_social/publicacoes/folderparticipacao-social>. Acesso em: 11 nov.2013. 


\section{ANEXO E - COMPARATIVO DE CONFERÊNCIAS POR TEMAS E ANOS}

\begin{tabular}{|c|c|c|c|}
\hline CONFERÊNCIAS & ÓRGÃO RESPONSÁVEL & ANO(S) & QTDE \\
\hline $\begin{array}{l}\text { Conferência Brasileira de Arranjos Produtivos } \\
\text { Locais }\end{array}$ & Ministério do Desenvolvimento, Indústria e Comércio & $\begin{array}{l}2004,2005,2007,2009,2011, \\
2013\end{array}$ & 6 \\
\hline $\begin{array}{l}\text { Conferência das Comunidades Brasileiras no } \\
\text { Exterior }\end{array}$ & Ministério das Relações Exteriores & $2008,2009,2010,2013$ & 4 \\
\hline Conferência Nacional das Cidades & Ministério das Cidades & $2003,2005,2007,2010,2013$ & 5 \\
\hline $\begin{array}{c}\text { Conferência Nacional de Aprendizagens } \\
\text { Profissional }\end{array}$ & Ministério do Trabalho e Emprego & 2008 & 1 \\
\hline Conferência Nacional de Aquicultura e Pesca & Ministério da Pesca e Aquicultura & $2003,2006,2009$ & 3 \\
\hline Conferência Nacional de Assistência Social & $\begin{array}{c}\text { Ministério do Desenvolvimento Social e Combate á } \\
\text { Fome }\end{array}$ & $\begin{array}{l}1995,1997,2001,2003,2005 \\
2007,2009,2011,2013,2015\end{array}$ & 10 \\
\hline $\begin{array}{c}\text { Conferência Nacional de Assistência Técnica e } \\
\text { Extensão Rural }\end{array}$ & Ministério do Desenvolvimento Agrário & 2012 & 1 \\
\hline $\begin{array}{c}\text { Conferência Nacional de Ciência, Tecnologia e } \\
\text { Inovação }\end{array}$ & Ministério da Ciência e Tecnologia & $1985,2001,2005,2010$ & 4 \\
\hline $\begin{array}{l}\text { Conferência Nacional de Ciência, Tecnologia e } \\
\text { Inovação em Saúde }\end{array}$ & Ministério da Saúde & 1994,2004 & 2 \\
\hline Conferência Nacional de Comunicação & Ministério das Comunicações & 2009 & 1 \\
\hline Conferência Nacional de Cultura & Ministério da Cultura & $2005,2010,2013$ & 3 \\
\hline $\begin{array}{c}\text { Conferência Nacional de Defesa Civil e } \\
\text { Assistência Humanitária }\end{array}$ & Ministério da Integração Nacional & 2010,2014 & 2 \\
\hline $\begin{array}{c}\text { Conferência Nacional de Desenvolvimento Rural } \\
\text { e Sustentável }\end{array}$ & Ministério do Desenvolvimento Agrário & 2008,2013 & 2 \\
\hline Conferência Nacional de Direitos Humanos & Secretaria de Direitos Humanos & $\begin{array}{c}\text { 1996, 1997, 1998, 1999, 2000, } \\
2001,2002,2003,2004,2006, \\
2008,2016\end{array}$ & 11 \\
\hline Conferência Nacional de Economia Solidária & Ministério do Trabalho e Emprego & $2006,2010,2014$ & 3 \\
\hline Conferência Nacional de Educação & Ministério da Educação & 2010,2014 & 2 \\
\hline Conferência Nacional de Educação Básica & Ministério da Educação & 2008 & 1 \\
\hline \multirow{2}{*}{$\begin{array}{c}\text { Conferência Nacional de Educação Escolar } \\
\text { Indígena }\end{array}$} & Ministério da Educação & \multirow[t]{2}{*}{2009} & \multirow[t]{2}{*}{1} \\
\hline & Ministério da Justiça & & \\
\hline $\begin{array}{c}\text { Conferência Nacional de Educação Profissional } \\
\text { Tecnológica }\end{array}$ & Ministério da Educação & 2006 & 1 \\
\hline
\end{tabular}




\begin{tabular}{|c|c|c|c|}
\hline $\begin{array}{c}\text { Conferência Nacional de Emprego e Trabalho } \\
\text { Decente }\end{array}$ & Ministério do Trabalho e Emprego & 2012 & 1 \\
\hline $\begin{array}{c}\text { Conferência Nacional de Gays, Lésbicas, } \\
\text { Bissexuais, Travestis e Transexuais }\end{array}$ & Secretaria de Direitos Humanos & $2008,2011,2016$ & 2 \\
\hline \multirow{2}{*}{$\begin{array}{l}\text { Conferência Nacional de Gestão do Trabalho e } \\
\text { da Educação na Saúde }\end{array}$} & Ministério da Saúde & \multirow[t]{2}{*}{ 1986, 1994, 2006} & \multirow[t]{2}{*}{3} \\
\hline & $\begin{array}{l}\text { Ministério do Trabalho e Emprego e } \\
\text { Ministério da Previdência Social }\end{array}$ & & \\
\hline Conferência Nacional de Juventude & Secretaria-Geral da Presidência da República & $2008,2011,2015$ & 3 \\
\hline $\begin{array}{c}\text { Conferência Nacional de Medicamentos e } \\
\text { Assistência Farmacêutica }\end{array}$ & Ministério da Saúde & 2003 & 1 \\
\hline $\begin{array}{l}\text { Conferência Nacional de Políticas Públicas de } \\
\text { Promoção da Igualdade Racial }\end{array}$ & $\begin{array}{l}\text { Secretaria de Políticas de Promoção da Igualdade } \\
\text { Racial }\end{array}$ & $2005,2009,2013$ & 3 \\
\hline $\begin{array}{l}\text { Conferência Nacional de Políticas Públicas para } \\
\text { as Mulheres }\end{array}$ & Secretaria de Políticas para as Mulheres & $2004,2007,2011,2016$ & 3 \\
\hline $\begin{array}{c}\text { Conferência Nacional de Recursos Humanos da } \\
\text { Administração Pública Federal }\end{array}$ & Ministério do Planejamento, Orçamento e Gestão & 2009 & 1 \\
\hline Conferência Nacional de Saúde & Ministério da Saúde & $\begin{array}{l}1941,1950,1963,1967,1975 \\
1977,1980,1986,1992,1996, \\
2000,2003,2007,2011,2015\end{array}$ & 15 \\
\hline \multirow[t]{3}{*}{ Conferência Nacional de Saúde Ambiental } & Ministério da Saúde & \multirow{3}{*}{2009} & \multirow[t]{3}{*}{1} \\
\hline & Ministério das Cidades & & \\
\hline & Ministério do Meio Ambiente & & \\
\hline Conferência Nacional de Saúde Bucal & Ministério da Saúde & $1986,1993,2004$ & 3 \\
\hline Conferência Nacional de Saúde do Trabalhador & Ministério da Saúde & 1986, 1994, 2005, 2014 & 4 \\
\hline Conferência Nacional de Saúde Indígena & Ministério da Saúde & $1986,1993,2001,2006,2013$ & 5 \\
\hline Conferência Nacional de Saúde Mental & Ministério da Saúde & $1987,1992,2001,2010$ & 4 \\
\hline $\begin{array}{c}\text { Conferência Nacional de Segurança Alimentar e } \\
\text { Nutricional }\end{array}$ & Conselho Nacional de Segurança Alimentar & $1994,2004,2007,2011,2015$ & 5 \\
\hline Conferência Nacional de Segurança Pública & Ministério da Justiça & 2009,2016 & 1 \\
\hline Conferência Nacional do Esporte & Ministério do Esporte & $2004,2006,2010,2016$ & 3 \\
\hline Conferência Nacional do Meio Ambiente & Ministério do Meio Ambiente & $2003,2005,2008,2013$ & 4 \\
\hline $\begin{array}{l}\text { Conferência Nacional dos Direitos da Criança e } \\
\text { do Adolescente }\end{array}$ & Secretaria dos Direitos Humanos & $\begin{array}{l}1995,1997,1999,2001,2003, \\
2005,2007,2009,2012,2016\end{array}$ & 9 \\
\hline $\begin{array}{l}\text { Conferência Nacional dos Direitos da Pessoa } \\
\text { com Deficiência }\end{array}$ & Secretaria dos Direitos Humanos & $2006,2008,2012,2016$ & 3 \\
\hline
\end{tabular}




\begin{tabular}{|c|c|c|c|}
\hline $\begin{array}{l}\text { Conferência Nacional dos Direitos da Pessoa } \\
\text { Idosa }\end{array}$ & Secretaria dos Direitos Humanos & $2006,2009,2011,2016$ & 3 \\
\hline Conferência Nacional dos Povos Indígenas & $\begin{array}{c}\text { Ministério da Justiça } \\
\text { FUNAI }\end{array}$ & 2006,2015 & 2 \\
\hline $\begin{array}{l}\text { Conferência Nacional Infanto-Juvenil pelo Meio } \\
\text { Ambiente }\end{array}$ & Ministério da Educação & $2003,2006,2009,2013$ & 4 \\
\hline $\begin{array}{c}\text { Conferência Nacional sobre transparência e } \\
\text { controle social }\end{array}$ & Controladoria Geral da União & 2012 & 1 \\
\hline Conferência Nacional Indigenista & & 2015 & 1 \\
\hline Conferência Nacional de Turismo & Ministério do Turismo & 2016 & 0 \\
\hline & TOTAL & & 143 \\
\hline
\end{tabular}

Legenda:

2016 - Conferência previstas

\footnotetext{
Adaptado de: BRASIL. Secretaria de Governo. Conferências Nacionais, Gráfico, 1941-2013. Disponível em:< http://www.secretariageral.gov.br/participacao-social/conferencias/conferencias-nacionais-grafico-1941-2013/view>. Acesso em: 10 nov. 2015.

BRASIL. Secretaria-Geral da Presidência da República. Calendário das Conferências Nacionais 2015-2016. Disponível em:< http://www.participa.br/portal/blog/calendario-das-conferencias-nacionais-2015-2016.>. Acesso em: 10 nov.2015.
} 


\title{
ANEXO F - ATA DA REUNIÃO DO COMJUV COM AUTORIZAÇÃO AO USO DOS RELATÓRIOS FINAIS
}

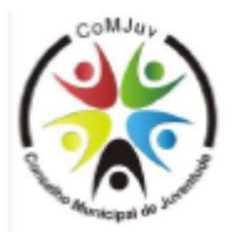

\author{
Conselho Municipal de Juventude \\ Municipio de Santa Bárbara D'Oeste
}

Ata da reunião ordinária do Conselho Municipal de Juventude de Santa Bárbara d'Oeste - SP, ocorrida aos quatorze dias do mês de março de dois mil e quinze.

Aos quatorze dias do mês de março do ano de dois mil e quinze, às quatorze horas, no Centro de Artes e Esportes Unificados, no anfi teatro, nesta cidade de Santa Bárbara d'Oeste, Estado de São Paulo, aconteceu a reunião ordinária do Conselho Municipal de Juventude, contando com a presença dos seguintes membros: PODER PÚBLICO: Miguel Brito, representante da Secretaria Municipal de Desenvolvimento Econômico e Giovanni Bonfim - representante da Câmara Municipal de Santa Bárbara d'Oeste ; SOCIEDADE CIVIL: Bruno Zeferino da Silva - representante de Entidade de Classe $(\mathrm{OAB})$; Andréa Brito Gobetti e Tainá Paula Tonon da Costa - representante do movimento religioso; Rodrigo Crivelaro, representante dos profissionais da Educação; e Roberto Mendes dos Santos - representante dos partidos politicos com juventude organizada, representante dos Grêmios Estudantis Municipais. A reunião teve início com a leitura da seguinte pauta apresentada pelo Presidente do Conselho, Bruno Zeferino da Silva: 1.Conferência Municipal de Juventude; 2.Elaboração da Pauta para ser discutida com o prefeito Denis Eduardo Andia, na reunião agendada para o dia vinte e quatro de março de dois mil e quinze, às quatorze horas e trinta minutos.; 3. Assuntos gerais. Após a leitura da pauta, o Presidente deu sequência na reunião, começando pelo primeiro assunto, a l. Conferência Municipal de Juventude. Até o momento ocorrem complicações com a chamada da Conferência Nacional, o que implica na realização das etapas anteriores. De acordo com o Conselheiro Rodrigo, ainda não possuímos a informação de quantos delegados o CoMJuv poderá eleger para a etapa Estadual, as formas de participação e se na Etapa Municipal pode ser indicado delegado por indicação direta. 2. Elaboração da Pauta para ser discutida com o prefeito Denis Eduardo Andia. O segundo assunto em pauta teve início com o levantamento de problemáticas e questões presentes na relação do CoMJuv com o Poder Executivo, sendo essas: A. Quais os compromissos daqui até o final do mandato com a Juventude Barbarense?; B. Referente à Divisão Municipal de Juventude, se não for possivel a 


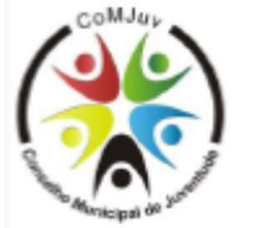

Conselho Municipal de Juventude

Municipio de Santa Bárbara D'Oeste

contratação de novos funcionários para compor a Divisão, é possivel realizar transferências de funcionários de outros setores para compor a Divisão e que a mesma não continue com apenas um profissional, o que prejudica no desenvolvimento das resoluções das questões da juventude?; C. Quanto ao Plano Municipal de Juventude, quais demandas dentro deste plano é possivel realizar até o final do mandato?; D. Na gestão do ex-prefeito Sr. Mário Celso Heins, havia um orçamento para uma pista de skate no parque Jacarandás. Ouve andamento? E. Dificuldades encontradas para a realização da Semana Municipal da Juventude e F. Pagamento da Parada Poética. Segundo Vereador Giovanni, a Prefeitura abusa da burocracia, o que é ineficiente na resolução de alguns problemas simples. Tais assuntos serão abordados pelos conselheiros na próxima reunião com Prefeito Denis. 3. Assuntos Gerais: O último assunto abordado foi o pedido feito pelo Conselheiro e Pesquisador Rodrigo Crivelaro, que desenvolve a pesquisa intitulada "O que a rebeldia teima? Capturas e resistências das juventudes nas conferências", na Universidade de São Paulo, solicitando autorização para utilizar os relatórios finais das Conferências Municipais de Juventude. A solicitação foi aprovada por todos os presentes. Nada mais havendo a ser tratado, encerrou-se a reunião às dezesseis horas e nove minutos, sendo lavrada a presente Ata por mim, Tainá Paula Tonon da Costa, Primeira Secretária Geral do CoMJuv, a qual segue assinada. Santa Bárbara d'Oeste, quinze de março de dois mil e quinze. 


\section{ANEXO G - PLATAFORMA BRASIL - PARECER CONSUBSTÂNCIADO}

\section{ESCOLA DE ARTES, CIÊNCIAS Plotoforma E HUMANIDADES - EACH/USP}

\section{PARECER CONSUBSTANCIADO DO CEP}

\section{DADOS DO PROJETO DE PESQUISA}

Título da Pesquisa: O que a rebeldia teima? Capturas e resistências das juventudes nas conferências

Pesquisador: RODRIGO CRIVELARO

Área Temática:

Versäo: 1

CAAE: 41384814.9 .0000 .5390

Instituição Proponente: Escola de Artes, Ciências e Humanidades - EACH/USP

Patrocinador Principal: Financiamento Próprio

\section{DADOS DO PARECER}

Número do Parecer: 950.180

Data da Relatoria: 08/02/2015

\section{Apresentação do Projeto:}

Segundo o pesquisador responsável, a presente pesquisa visa a compreensão de como os discursos sobre jovem e a juventude são produzidos no espaço das conferências de juventude, sendo estas uma forma de participação muito utilizada para seleção de demandas de políticas públicas. O pesquisador buscará compreender como esta forma de participação interage com a juventude e como a juventude interage nela criando novas formas de fazer política, de conceber a cidadania, o sujeito e o direito, ou seja, as possibilidades de participação e se as mesmas são possiveis.

\section{Objetivo da Pesquisa:}

Objetivo Primário:

Conhecer e problematizar os discursos de jovens de Santa Bárbara d'Oeste sobre as conferências de juventude e as políticas públicas de juventude

no município.

O pesquisador indica os seguintes objetivos de pesquisa:

Objetivo Secundário:

Compreender as construções discursivas sobre o ser jovem e a definições de juventude dos envolvidos nas conferências de juventude em Santa

Endereço: Av. Arlindo Béttio, $n^{\circ} 1000$

Bairro: Ermelino Matarazzo

CEP: $03.828-000$

UF: SP Município: SAO PAULO

Telefone: (11)3091-1046

E-mail: cep-each@usp.br 


\section{ESCOLA DE ARTES, CIÊNCIAS Platoformo E HUMANIDADES - EACH/USP}

Continuação do Parecer: 950.180

Bárbara d'Oeste;

Avaliação dos Riscos e Benefícios:

São indicados como os riscos e benefícios da pesquisa:

Riscos: Por tratar-se de uma pesquisa que utiliza a fala como forma de produção de dados, apresenta riscos mínimos a saúde.

Benefícios: Melhor compreensão a cerca de qual o alcance das conferência entre a juventude, e quais as possibilidades de participação são produzidos neste espaço.

\section{Comentários e Consideraçōes sobre a Pesquisa:}

Trata-se de uma pesquisa do tipo levantamento que se encontra em fase de exploração de informações por meio de entrevistar para melhor conhecer a opinião e o discurso dos jovens sobre a conferência da juventude das políticas públicas para a juventude.

Consideraçōes sobre os Termos de apresentação obrigatória:

O TCLE apresentado contempla as necessidade previstas no campo da ética em pesquisa.

\section{Recomendaçöes:}

O projeto de pesquisa está de acordo com as exigências do CONEP.

Conclusões ou Pendências e Lista de Inadequaçōes:

Considera-se o projeto de pesquisa adequado às exigências da ética em pesquisa com seres humanos,

Situação do Parecer:

Aprovado

Necessita Apreciação da CONEP:

Não

Consideraçōes Finais a critério do CEP:

\section{ESCOLA DE ARTES, CIÊNCIAS Plotoformo E HUMANIDADES - EACH/USP}

Continuação do Parecer: 950.180

Assinado por:

Beatriz Aparecida Ozello Gutierrez

(Coordenador) 


\section{ANEXO H - RESOLUÇÕES DA $1^{\text {a }}$ CONFERÊNCIA NACIONAL DE JUVENTUDE}

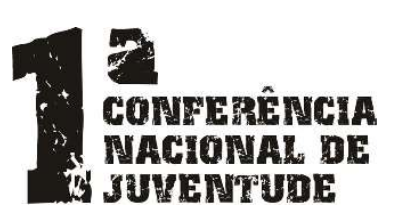

Resultado do Momento Interativo

Prioridades da Conferência Nacional de Juventude

\begin{tabular}{|c|c|c|}
\hline & Tema & Proposta \\
\hline 1 & $\begin{array}{l}\text { Jovens negros e } \\
\text { negras }\end{array}$ & $\begin{array}{l}\text { Reconhecimento e aplicação, pelo poder público, transformando em políticas públicas de juventude as resoluções do } 1^{\circ} \text { Encontro Nacional de Juventude Negra } \\
\text { (ENJUNE), priorizando as mesmas como diretrizes étnico/raciais de/para/com as juventudes. }\end{array}$ \\
\hline 2 & $\begin{array}{l}\text { Educação } \\
\text { básica - } \\
\text { elevação da } \\
\text { escolaridade }\end{array}$ & Destinar parte da verba da educação no ensino básico para o modelo integral e pedagógico do CIEP’s ( Centros Integrados de Educação Pública). \\
\hline 3 & $\begin{array}{l}\text { Fortalecimento } \\
\text { institucional }\end{array}$ & $\begin{array}{c}\text { Aprovação pelo Congresso Nacional do marco legal da juventude: regime de urgência da PEC n. }{ }^{\circ} \text { 138-B/2003, Plano Nacional de Juventude e Estatuto dos } \\
\text { Direitos da Juventude PL 27/2007. }\end{array}$ \\
\hline 4 & Meio Ambiente & $\begin{array}{l}\text { Criar uma política nacional de juventude e meio ambiente que inclua o "Programa Nacional de Juventude e Meio Ambiente", institucionalizado em PPA (Plano } \\
\text { Plurianual), com a participação dos jovens nos processos de construção, execução, avaliação e decisão, bem como da Agenda } 21 \text { da Juventude que fortaleça } \\
\text { os movimentos juvenis no enfrentamento da grave crise ambiental global e planetária, com a construção de sociedades sustentáveis. }\end{array}$ \\
\hline 5 & Esporte & $\begin{array}{c}\text { Ampliar e qualificar os programas e projetos de esporte, em todas as esferas públicas, enquanto políticas de Estado, tais como os programas Esporte e Lazer } \\
\text { da Cidade, Bolsa Atleta e Segundo Tempo com núcleos nas escolas, universidades e comunidades, democratizando o acesso ao esporte e ao lazer a jovens, } \\
\text { articulados com outros programas existentes. }\end{array}$ \\
\hline 6 & $\begin{array}{l}\text { Juventude do } \\
\text { campo }\end{array}$ & $\begin{array}{c}\text { Garantir o acesso à terra ao jovem e à jovem rural, na faixa etária de } 16 \text { a } 32 \text { anos, independente do estado civil, por meio da reforma agrária, priorizando este } \\
\text { segmento nas metas do Programa de Reforma Agrária do Governo Federal, atendendo a sua diversidade de identidades sociais, e, em especial aos } \\
\text { remanescentes de trabalho escravo. É fundamental a revisão dos índices de produtividade e o estabelecimento do limite da propriedade para } 35 \text { módulos } \\
\text { fiscais. }\end{array}$ \\
\hline
\end{tabular}




\begin{tabular}{|c|c|c|}
\hline 7 & Trabalho & $\begin{array}{c}\text { Reduzir a jornada de trabalho de } 44 \text { para } 40 \text { horas semanais sem redução de salários, conforme campanha nacional unificada promovida pelas centrais } \\
\text { sindicais. }\end{array}$ \\
\hline 8 & $\begin{array}{l}\text { Educação } \\
\text { Superior }\end{array}$ & $\begin{array}{l}\text { Defendemos que a ampliação do investimento em educação é fator imprescindivel para construirmos uma educação de qualidade para todos e todas e que } \\
\text { consiga contribuir para o desenvolvimento do País. Para tanto, defendemos o investimento de } 10 \% \text { do PIB em educação. Para atingir este percentual } \\
\text { reivindicamos o fim da desvinculação das receitas da união (DRU) e a derrubada dos vetos ao PNE (Plano Nacional de Educação). Reivindicamos que } 14 \% \\
\text { dos recursos destinado as universidades federais seja destinado exclusivamente à assistência estudantil por meio da criação de uma rubrica específica. } \\
\text { Defendemos também a ampliação dos recursos em assistência estudantil para estudantes do PROUNN e para estudantes de baixa renda de universidades } \\
\text { privadas. Garantir a transparência e democracia na aplicação dos recursos. }\end{array}$ \\
\hline 9 & Cultura & $\begin{array}{l}\text { Criação, em todos os municííios, de espaços culturais públicos, descentralizados, com gestão compartilhada e financiamento direto do estado, que atendam às } \\
\text { especificidades dos jovens e que tenham programação permanente e de qualidade. Os espaços, sejam eles construções novas, desapropriações de imóveis } \\
\text { desocupados ou organizações da sociedade civil já estabelecidas, devem ter condições de abrigar as mais diversas manifestações artísticas e culturais, } \\
\text { possibilitando o aprendizado, a fruição e a apresentação da produção cultural da juventude. Reconhecer e incentivar o hip hop como manifestação cultural e } \\
\text { artística. }\end{array}$ \\
\hline 10 & $\begin{array}{l}\text { Política e } \\
\text { Participação }\end{array}$ & $\begin{array}{l}\text { Criar o Sistema Nacional de Juventude, composto por Órgãos de Juventude (Secretarias/coordenadorias e outros) nas três esferas do Governo, com dotação } \\
\text { orçamentária específica; Conselhos de Juventude eleitos democraticamente, com caráter deliberativo, com a garantia de recursos financeiros, físicos e } \\
\text { humanos; Fundos Nacional, estaduais e municipais de Juventude, com acompanhamento e controle social, ficando condicionado o repasse de verbas federais } \\
\text { de programas de projetos de juventude à adesão dos estados e municípios a esse Sistema. }\end{array}$ \\
\hline 11 & Jovens mulheres & $\begin{array}{l}\text { Implementar políticas públicas de promoção dos direitos sexuais e direitos reprodutivos das jovens mulheres, garantindo mecanismos que evitem mortes } \\
\text { maternas, aplicando a lei de planejamento familiar, garantindo o acesso a métodos contraceptivos e a legalização do aborto. }\end{array}$ \\
\hline 12 & Segurança & Contra a redução da maioridade penal, pela aplicação efetiva do Estatuto da Criança e do Adolescente - ECA \\
\hline 13 & $\begin{array}{l}\text { Política e } \\
\text { participação }\end{array}$ & $\begin{array}{c}\text { Garantir uma ampla reforma política que, além do financiamento público de campanha, assegure a participação massiva da Juventude nos partidos políticos, } \\
\text { com garantia de cota mínima de } 15 \% \text { para jovens de } 18 \text { a } 29 \text { anos nas coligações, com respeito ao recorte étnico-racial e garantindo a paridade de gênero; } \\
\text { Mudança na faixa-etária da elegibilidade garantindo como idade mínima de } 18 \text { anos para vereador, prefeito, deputados estaduais, distritais e federais e } 27 \text { anos } \\
\text { para senador, governador e presidente da República. }\end{array}$ \\
\hline 14 & Outros temas & Fim da obrigatoriedade do serviço militar, e criação de programas alternativos de serviços sociais não obrigatórios. \\
\hline 15 & $\begin{array}{l}\text { Fortalecimento } \\
\text { institucional }\end{array}$ & $\begin{array}{l}\text { Criar o Sistema Nacional de Políticas Públicas de Juventude que confira status de Ministério à Secretaria Nacional de Juventude, exigindo que a adesão de } \\
\text { estados e municípios seja condicionada à existência de órgão gestor específico e respectivo conselho de juventude. A partir de dezembro de } 2009 \text {, os recursos } \\
\text { do Fundo Nacional de Juventude, do ProJovem e demais programas de juventude, apenas continuarão a ser repassados aos estados e municípios que } \\
\text { aderirem ao Sistema. }\end{array}$ \\
\hline
\end{tabular}




\begin{tabular}{|c|c|c|}
\hline 16 & $\begin{array}{l}\text { Povos e } \\
\text { comunidades } \\
\text { tradicionais }\end{array}$ & $\begin{array}{c}\text { Assegurar os direitos dos povos e comunidades tradicionais (quilombolas, indígenas, ciganos, comunidades de terreiros, pescadores artesanais, caiçaras, } \\
\text { faxinalenses, pomeranos, pantaneiros, quebradeiras de coco babaçu, caboclos, mestiços, agroextrativistas, seringueiros, fundos de pasto, dentre outros que } \\
\text { buscam ser reconhecidos), em especial da juventude, preservando suas culturas, línguas e costumes, combatendo todas as práticas exploratórias e } \\
\text { discriminatórias quanto a seus territórios, integrantes, saberes, práticas culturais e religiosas tradicionais. }\end{array}$ \\
\hline 17 & Cultura & $\begin{array}{c}\text { Estabelecimento de políticas públicas culturais permanentes direcionadas à juventude, tendo ética, estética e economia como pilares, em gestão compartilhada } \\
\text { com a sociedade civil, a exemplo dos Pontos de Cultura, que possibilitem o acesso a recursos de maneira desburocratizada, levando em consideração a } \\
\text { diversidade cultural de cada região e o diálogo intergeracional. Criação de um mecanismo especifico de apoio e incentivo financeiro aos jovens (bolsas) para } \\
\text { formaçãa e capacitação como artistas, animadores e agentes culturais multiplicadores. }\end{array}$ \\
\hline 18 & Cidadania GLBT & $\begin{array}{l}\text { Incentivar e garantir a SENASP/MJ a incluir em todas as esferas dos cursos de formação dos operadores/as de segurança pública e privada em nível nacional, } \\
\text { estadual e municipal no atendimento e abordagem e no aprendizado ao respeito à livre orientação afetivo-sexual e de identidade de gênero com ampliação do } \\
\text { DECRADI - Delegacia de Crimes Raciais e Intolerância. }\end{array}$ \\
\hline 19 & $\begin{array}{l}\text { Jovens com } \\
\text { deficiência }\end{array}$ & Ratificação imediata da Convenção sobre os Direitos da Pessoa com Deficiência da ONU como emenda constitucional. \\
\hline 20 & $\begin{array}{l}\text { Jovem do } \\
\text { Campo }\end{array}$ & $\begin{array}{l}\text { Garantia de políticas públicas integradas que promovam a geração de trabalho e renda para o jovem e a jovem do campo, com participação da juventude na } \\
\text { sua elaboração e gestão. Assegurando o acesso a terra, à capacitação e ao desenvolvimento de tecnologia sustentável apropriada à agricultura familiar e } \\
\text { camponesa voltada para a mudança de matriz tecnológica. Transformar o Pronaf Jovem em uma linha de crédito para produção agrícola e não agrícola. }\end{array}$ \\
\hline 21 & Segurança & $\begin{array}{l}\text { Assegurar, no âmbito das Políticas Públicas de Segurança, prioridade às ações de prevenção, promoção da cidadania e controle social, reforçando a pratica do } \\
\text { policiamento comunitário, priorizando áreas com altas taxas de violência, promovendo melhoria da infra-estrutura local, adequadas condições de trabalho } \\
\text { policial, remuneração digna e a formação nas áreas de Direitos Humanos e Mediação de Conflitos, conforme as diretrizes apontadas pelo PRONASCl. }\end{array}$ \\
\hline 22 & Cultura & $\begin{array}{l}\text { Estabelecimento de cotas de exibição e programação de } 50 \% \text { para a produção cultural Brasileira, sendo } 15 \% \text { produção independente e } 20 \% \text { produção regional } \\
\text { em todos os meios de comunicação (TV aberta e paga, rádios e cinemas). Valorização dos artistas locais garantindo a preferência nas apresentaçôes e } \\
\text { prioridade no pagamento. Entender os cineclubes como espaç̧ privilegiados de democratização do áudio visual. }\end{array}$ \\
\hline
\end{tabular}

BRASIL. Secretaria Nacional de Juventude. $1^{\text {a }}$ Conferência Nacional de Juventude. Disponível em: <http://juventude.gov.br/conferencia/1a-conferencia-nacional-de-juventude/>. Acesso em: 07 nov.2015. 


\section{ANEXO I - PARA DESENVOLVER O BRASIL !}

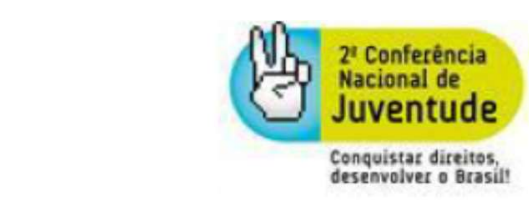

\section{PARA DESENVOLVER O BRASIL !}

Considerando que as políticas públicas de juventude não estão descoladas do conjunto da sociedade e devem estar conectadas aos desafios atuais que 0 país enfrenta, os jovens não pleiteiam somente a resolução de seus problemas. Buscam, também, oportunidades para debater e interferir nas questões mais amplas colocadas na conjuntura e nas definições dos rumos do Brasil.

Sendo assim, os jovens presentes à $2^{\text {a }}$ Conferência Nacional de Juventude propõem:

\section{Eixo 1: Desenvolvimento Integral da Juventude}

1. Garantir $10 \%$ do PIB - até o ano de 2014 - como investimento mínimo para a Educação no Brasil, distribuindo o valor per capita de acordo com as necessidades e realidades de cada região.

2. Assegurar que $50 \%$ do fundo social do pré-sal ( $50 \%$ dos Royalties) tenham como destino o financiamento da educação publica.

3. Garantir o cumprimento da legislação em que a União deve investir $18 \%$ de seu orçamento em educação e $25 \%$ do orçamento dos estados e municípios, e que os professores inativos não sejam pagos com esses recursos.

4. Criar o Fundo Social do Minério, com investimento de $50 \%$ do mesmo em educação pública.

5. Reduzir imediatamente a taxa de juros brasileira e garantir que esses recursos sejam destinados ao orçamento brasileiro para a educação.

6. Valorizar os profissionais da educação, em cumprimento da lei do piso salarial, em todas as esferas do governo.

7. Valorizar permanentemente o piso salarial do magistério. 


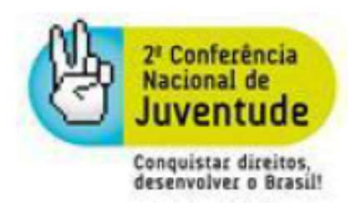

8. Criar um plano de carreira nacional, garantindo: concursos com vista à maior estabilidade na profissão e diminuição da rotatividade, remuneração adequada, remuneração do tempo gasto no planejamento das aulas e correção de atividade, assim como capacitação e pesquisa, formação inicial e continuada dos profissionais em educação, cumprindo o Plano Nacional de Educação (PNE).

9. Reduzir a jornada de trabalho de 44 horas semanais para 40 horas e para 30 horas semanais para os trabalhadores da saúde, sem redução de salário para os trabalhadores, favorecendo a juventude, que poderá trabalhar, conciliar estudos, esporte, cultura e lazer.

10. Efetivar as convenções da OIT (Organização Internacional do Trabalho), para assegurar melhores condições de trabalho.

11. Aprovar e efetivar as convenções 156 (relativa à igualdade de oportunidades e de tratamento para os trabalhadores e trabalhadoras com responsabilidades familiares), 111 (sobre a discriminação em matéria de emprego e profissão) e 100 (sobre salário igual para homens e mulheres na mesma profissão) da OIT.

12. Garantir a convenção 140 da OIT, que permite licença remunerada para estudos e qualificação profissional por tempo determinado aos trabalhadores.

13. Garantir amplo exercício dos direitos coletivos, por meio da representação sindical nos locais de trabalho, do direito de negociação, de organização e solução ágil dos conflitos, de combate às práticas antissindicais e da dispensa imotivada. (Ratificação da Convenção 158 da OIT, e regulamentação da Convenção 151 da OIT).

14. Aprovar e efetivar, em caráter de urgência, os planos nacionais, estaduais e municipais de cultura, assegurando dotação orçamentária para esse segmento a partir dos PIB Federal $(2 \%)$, dos Estados $(1,5 \%)$ e Municipais $(1 \%)$.

15. Proceder à aprovação imediata da PEC $n^{\circ} 150 / 2003$, que destina recursos à cultura nas três esferas do poder (nacional, estaduais, distrito federal e municípios). 


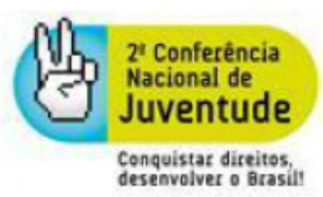

16. Democratizar os meios de comunicação, garantindo $\circ$ amplo acesso à informação e aos meios de comunicação (Internet, Radio, TV, Jornais e Imprensa Oficial e audiovisual), com participação obrigatória das produções independentes, com abertura de editais em apoio à produção artística.

17. Reformar a lei dos direitos autorais sob a ótica de que o conhecimento é livre: sendo assim, incentivar a utilização de licenças creative commons, sob, a égide de uma filosofia copyleft.

18. Estabelecer cotas de exibição e programação de $50 \%$ para a produção cultural brasileira, sendo $15 \%$ produção independente e $20 \%$ produção regional em todos os meios de comunicação (TV aberta e paga, rádios e cinemas).

19. Criar um novo marco regulatório das comunicações, que garanta o controle social sobre as políticas públicas na área, assegurando conselhos de comunicação em todas as esferas e que esses garantam respeito aos direitos humanos, com conteúdos não discriminatórios, não machistas e não racistas nas veiculações midiáticas e criação de regras para a concessão de outorgas.

20. Garantir o direito à liberdade de expressão e ao livre acesso à informação e à comunicação, previstos na Constituição Federal, no uso das mídias, assegurando a pluralidade de ideias e opiniões dos diferentes grupos sociais e culturais.

21. Promover mecanismos institucionais de democratização da distribuição e da aplicação de verbas públicas em publicidade de ações governamentais em rádios e TVs comunitárias, bem como a instrumentalização de fundos permanentes de financiamento das atividades de comunicação comunitária e com finalidade social, bem como a reformulação da lei 9.612/98, garantindo a ampliação da potência permitida para rádios comunitárias, ampliação de canais para rádios e tevês comunitárias, maior agilidade no processo de concessão, descriminalização com anistia e devolução dos equipamentos apreendidos.

22. Aperfeiçoar, implementar e garantir a efetivação do controle social em todas as etapas de consolidação do Programa Nacional de Banda Larga (PNBL) - na ótica dos direitos humanos de comunicação e informação assegurando: a superação das atuais limitações, o acesso gratuito para todas as cidades $e$ áreas rurais, independentemente de densidade demográfica e o aproveitamento das redes de cabo de fibra ótica já instaladas para transmissão de dados, imagens e sons, assim como o 
aproveitamento dos equipamentos de alta velocidade que viabilizarão conexão com redes nacionais de telecomunicação e demais redes no Brasil e no mundo.

\section{EIXO 2: Direito ao Território}

23. Realizar uma reforma urbana que considere a cidade como espaço integrado de sociabilidade, de acesso aos serviços públicos de qualidade, que priorize a manutenção dos territorios dos povos e comunidades tradicionais de acolhimento e de estímulo à juventude.

24. Promover uma política social de habitação, a exemplo das casas populares ou conjuntos habitacionais de interesse social, que proporcionem à camada menos assistida da população uma melhor condição de moradia, com atenção especial para municípios que tenham menos de 50 mil habitantes.

25. Fomentar uma política de reconhecimento e fortalecimento da identidade juvenil e rural, considerando o seu contexto, com a valorização da história, produção e cultura do campo, com vistas ao enfrentamento do preconceito contra a juventude do campo.

26. Garantir o direito ao território, por meio da delimitação, demarcação, homologação e desintrusao e titulação das terras quilombolas, indígenas, povos e comunidades tradicionais reconhecidas e não reconhecidas.

27. Garantir $\circ$ acesso à terra e criar condições para permanência na mesma, com assistencia técnica ao jovem e à jovem do campo e comunidades ribeirinhas, na faixa etária de 16 a 32 anos, independente do estado civil, por meio da Reforma Agrária.

28. Abrir concurso público para agentes fiscalizadores dos órgãos de licenciamento ambiental nos Estados.

29. Ampliar e criar o sistema de transporte coletivo, fluvial ,terrestre, urbano, rural e escolar, intermunicipal e interestadual, garantido a acessibilidade, 0 conforto, a segurança e a assiduidade no cumprimento dos horários preestabelecidos. 
30. Providenciar a garantia e a manutenção do transporte público, facilitando $\circ$ acesso dos jovens, por meio de transparência dos custos do sistema e estatização do serviço, objetivando a redução da tarifa.

31. Adequar, ampliar e garantir a implementação de políticas publicas voltadas à juventude dos Povos e Comunidades Tradicionais. Atenção específica a comunidades distantes dos centros urbanos e à participação efetiva e direta dessas juventudes.

32. Garantir transparência das verbas utilizadas nos transportes públicos dos municípios, como forma de evitar a corrupção e garantir os direitos da juventude ao transporte urbano e intermunicipal.

\section{Eixo 3: Direito à experimentação e à Qualidade de Vida}

33. Fortalecer o SUS, garantindo a participação da juventude (de 15 a 29 anos) e respeitando as deliberações do controle social; fortalecendo o modelo de gestão pública, suprimindo o modelo de terceirização da gestão; interrompendo $\circ$ processo de privatização através das Organizações Sociais (OS's) e Organizações da Sociedade Civil de Interesse Público (OSCIP's); valorizando e qualificando os profissionais de saúde; garantindo recursos necessários para a plena execução das políticas públicas de saúde, com a regulamentação da EC29 através do PL306/2008, direcionando $10 \%$ do PIB para a saúde, com controle rígido do que são investimentos específicos para a saúde.

34. Fortalecer a Estratégia de Saúde da Família e qualificar a saúde pública para um atendimento humanizado, com a contratação de profissionais de saúde e funcionários nas unidades básicas de saúde, garantindo qualidade $e$ agilidade nos atendimentos, reformando e ampliando toda a estrutura fisica da Atenção Básica, tornando desnecessária a utilização dos planos de saúde privados, fortalecendo a Política Nacional de Assistência Farmacêutica e 0 acesso aos medicamentos pela população, de forma segura e racional, respeitando as necessidades regionais de forma igualitária, com implantação do sistema nacional de dados da saúde das populações tradicionais.

35. Fortalecer a Estratégia de Saúde da Família do Brasil e dobrar sua cobertura até 2014, respeitando as necessidades regionais de forma igualitária, com implantação do sistema nacional de dados da saúde das populações tradicionais. 


\section{Eixo 4: Direito à Diversidade e à Vida Segura}

36. Construir uma reforma na concepção de segurança pública no Brasil, com articulação de todos os entes federativos, que tenha como centro: a defesa da vida, o fim do modelo repressivo e o enfrentamento ao genocídio da juventude, com prioridade à juventude negra.

37. Combater o racismo institucional em todas as esferas da sociedade e no Estado brasileiro.

38. Garantir o fim da violência baseada em gênero (como, por exemplo, contra o machismo) e a valorização da diversidade étnico-racial, identidade de gênero e orientação sexual.

39. Desenvolver políticas articuladas para atender jovens mulheres, garantindo às mesmas acesso à educação e ao trabalho.

40. Transformar o modelo de medidas de restrição de liberdade, seja no sistema prisional ou em medidas sócioeducativas, na perspectiva da garantia efetiva dos direitos humanos.

41. Garantir a acessibilidade dos jovens com deficiência aos diversos espaços e meios de comunicação.

\section{Eixo 5: Direito à Participação}

42. Instituir uma reforma política que garanta a participação da juventude nos espaços eletivos de poder, contemplando, de forma igualitária, as questões etárias e de gênero.

43. Garantir cota de $20 \%$ para candidatos jovens nas coligações proporcionais das eleições gerais e municipais.

44. Criar cotas de $10 \%$ para a juventude nas candidaturas proporcionais e garantir que todos os partidos destinem $5 \%$ dos recursos do fundo partidário para atividade das juventudes partidárias. 


\title{
ANEXO J - RESOLUÇÕES APROVADAS NA $2^{\text {a }}$ CONFERÊNCIA NACIONAL DE JUVENTUDE
}

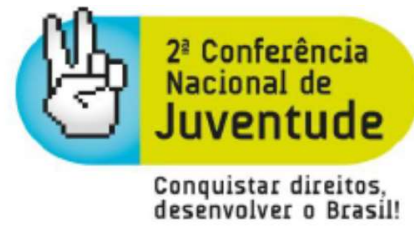 \\ PROPOSTAS FINAIS APROVADAS
}

\section{EIXO 1 - DESENVOLVIMENTO INTEGRAL}

\section{PROPOSTA 1}

Consolidar as políticas de educação inclusiva, por meio da garantia da implementação das Leis $11.645 / 08,10.639 / 03$, das Diretrizes Operacionais da Educação no/do campo em todos os estados,-_municípios e o Distrito Federal, bem como a garantia de oferta de Atendimento Educacional Especializado (AEE), complementar à escolarização dos jovens com deficiência e público alvo da educação especial; da ampliação e qualificação da oferta de alfabetização e educação de jovens e adultos, inclusive nas instituições de privação de liberdade, articulando os programas de alfabetização com as diferentes ofertas de EJA, como o PROJOVEM e o PROEJA, com metodologias, propostas pedagógicas e materiais didáticos e literários adequados, formação inicial e continuada dos educadores, com foco na juventude direcionada para este fim, garantindo, desse modo, a reforma curricular do ensino médio e fundamental, o ensino bilíngue de Libras e Língua portuguesa para estudantes surdos, "Braille", filosofia, sociologia e política, aprovando o plano de reestruturação das escolas públicas, proporcionando a inclusão e o acesso da juventude brasileira, em especial os jovens com deficiência, ao ensino regular, fundamental, médio, integral e integrado com a educação profissional, priorizando a gestão democrática, com o fortalecimento dos grêmios estudantis e, principalmente, a eleição direta para diretor. Garantir, ainda, a assistência estudantil e a acessibilidade no transporte público gratuito, promovendo, assim, a formação para a vida e para a cidadania dos jovens.

\section{PROPOSTA 2}

Ampliar e interiorizar a oferta de vagas públicas no ensino público superior, priorizando a interiorização, de forma que, em 2020, as vagas ofertadas sejam majoritariamente públicas, incluindo politicas de ações afirmativas, estabelecendo-se regulamentação para o ensino privado e políticas que garantam infraestrutura e condições adequadas para o desenvolvimento do ensino, da pesquisa na graduação e na pós-graduação e da extensão universitária, valorizando as especificidades de cada região, como também o acesso e a permanência a estas instituições por jovens de baixa renda, povos tradicionais, ribeirinhos, do campo, negros/negras, indigenas e jovens com deficiência, sobretudo aqueles oriundos de escolas públicas de educação básica, garantindo a formação de profissionais comprometidos com a diversidade étnico-racial do povo brasileiro. Extinção do exame vestibular como forma de acesso ao ensino superior. 


\section{PROPOSTA 3}

Ampliar e interiorizar os cursos técnicos, tecnológicos e profissionalizantes, criando escolas e democratizando o Sistema S, por meio de vagas gratuitas, contribuindo para a emancipação dos cidadãos para outras áreas de atuação, com o atendimento das exigencias e especificidades das diversas juventudes, da cidade, do campo, com deficiência, privados de liberdade, indígenas, de terreiros, extrativistas, ribeirinhos, negros e negras e quilombolas, entre outras comunidades tradicionais, considerando os diferentes locais e regiões, criando instrumentos e estratégias para que as politicas no âmbito da educação profissional sejam parte integrante do sistema nacional articulado de educação, desenvolvidas na perspectiva da educação inicial e continuada, articulada às modalidades de ensino, garantindo mecanismos de participação popular nos conselhos gestores, tais como: movimento estudantil, centrais sindicais, trabalhadores do campo e demais movimentos sociais, com a ampliação e o aprimoramento do controle social, respeitando a cidade, o campo e as pessoas com deficiência.

\section{PROPOSTA 4}

Construir e implementar um plano nacional de promoção do trabalho decente para a juventude, com indicadores e metas, tendo como base a Agenda Nacional do Trabalho Decente para a Juventude.

\section{PROPOSTA 5}

Fortalecer programas como Cultura Viva/Pontos de Cultura, do Ministério da Cultura, como forma de política permanente de investimentos destinados a iniciativas de grupos e movimentos culturais juvenis e populares, garantindo o aumento de editais simplificados, como os da modalidade "premiação", democratizando e desburocratizando as leis de fomento, assim como garantir uma política de cultura para a educação que estimule a produção artística dos estudantes e disponibilize acervo cultural (compra de discos e DVDs produzidos por gravadoras independentes nacionais do PNBE/MEC), para fazer das escolas espaço de circulação da cultura brasileira. Sendo assim, todos os profissionais da área cultural devem ser reconhecidos e regulamentados pelo Estado, tendo garantia ao trabalho decente, sendo assegurados todos os direitos trabalhistas, extinguindo-se a precarização do trabalho, por meio das Pessoas Jurídicas ou de qualquer forma de terceirização, garantindo-se também a criação de cursos de capacitação e formação nas demais áreas da cultura e das artes.

\section{PROPOSTA 6}

Criar e implementar o Plano Nacional de Comunicação e Juventude, que deve contemplar a criação e a ampliação dos Centros de Comunicação Popular, Telecentros, pontos de acesso público e o fomento à produção de mídias alternativas, como: 
programas de rádio, TV, mídias impressas, rádios escolares e comunitárias, internet etc., com prioridade para os/as jovens como proponentes e produtores, incentivando,, preferencialmente, mídias produzidas a partir de metodologia de "educomunicação", garantindo a expansão do acesso e a inclusão digital no campo e na cidade, ampliando os sinais de internet (banda larga) e telefonia, valorizando a cultura regional e garantindo a formação de educadores da rede pública para tratar dessa questão nas escolas e universidades.

\section{PROPOSTA 7}

Criar um programa de assistência estudantil obrigatório a todas as universidades brasileiras que atendam aos programas de inclusão (com criação de rubrica própria para assegurar esta assistência). Garantir a interiorização das universidades brasileiras, bem como políticas de Assistência Estudantil para todos os estudantes, contemplando os jovens negros, indigenas, com deficiência, do campo e estudantes africanos e latinoamericanos, tanto nos cursos de graduação quanto nos de pós-graduação, estabelecendo $2 \%$ do orçamento do MEC para a Assistência Estudantil.

\section{EIXO 2 - DIREITO AO TERRITÓRIO}

\section{PROPOSTA 1}

Garantir o direito à moradia digna aos jovens, incluindo os jovens de favela e os de comunidades tradicionais, levando em conta programas habitacionais existentes, incentivo fiscal e oferecimento de linha de crédito facilitada, com cotas destinadas aos jovens para aquisição da moradia própria, sem comprovação de renda e com subsídio governamental, especialmente para as jovens mães, considerando que esse direito não se restringe a um chão e a um teto, mas sim à habitação de um espaço que possibilite a efetivação de outros direitos, como acesso à educação, à geração de renda, à saúde, ao lazer, ao transporte público, ao saneamento básico e ambiental, à segurança e à acessibilidade, garantindo, assim, as condições de habitabilidade e de exercício da democracia direta, como a criação de conselhos gestores paritários e territorializados, criando um programa que fomente a autogestão e a construção da moradia social, capacitando os jovens, de forma que garanta a aplicação de políticas previstas no estatuto da cidade (Planos diretores, orçamentos participativo, entre outros), garantindo a manutenção no território dos povos e comunidades tradicionais urbanos, bem como ocupações urbanas e favelas como áreas especiais de interesse social, incluindo as políticas públicas da juventude arroladas pela $2^{\text {a }}$ Conferência Nacional de Juventude.

\section{PROPOSTA 2}

Criação de uma política pública de fomento específica para a juventude da agricultura familiar, camponesa, assalariada rural, para os povos e comunidades tradicionais (os reconhecidos e os que lutam pelo reconhecimento), que respeite os seguintes princípios:

(a) priorização, associativismo e cooperativismo; 
(b) valorização de práticas agroecológicas alternativas;

(c) acesso à terra e reforma agrária;

(d) priorização da participação dos jovens dos movimentos sociais e do campo na elaboração e no monitoramento dessa política;

(e) desburocratização das políticas já existentes e das novas políticas;

(f) qualificação técnica na produção, na gestão e na comercialização;

(g) geração de renda respeitando a pluriatividade.

\section{PROPOSTA 3}

Garantir o passe livre no transporte coletivo urbano, rural intermunicipal e interestadual para as juventudes e os estudantes, por meio da criação de lei.

\section{PROPOSTA 4}

Fortalecer a política nacional de juventude e meio ambiente e criar o programa nacional de juventude e meio ambiente, intersetorializado e institucionalizado no PPA (Plano Plurianual), na LOA (Lei de Orçamento Anual) na LDO (Lei de Diretrizes Orçamentárias), bem como a agenda 21 da juventude, de modo a fortalecer os movimentos juvenis e a agenda 21 brasileira no enfrentamento das graves crises ambientais, com a participação das juventudes nos processos de construção, execução, avaliação e decisão, sustentada por pesquisas periódicas.

\section{PROPOSTA 5}

Mapeamento, reconhecimento, delimitação, demarcação, homologação, titulação e desintrusão das terras e territórios, dos povos e das comunidades tradicionais reconhecidos e os que lutam pelo reconhecimento - visando à criação de políticas públicas e de programas que possibilitem a permanência dos jovens nas comunidades. Ampliação, por meio de concurso público, das equipes técnicas do INCRA, da FUNAI, da Fundação Palmares, da SEPPIR, da SESAI e do MDA, entre outros órgãos, em suas superintendências estaduais e regionais, com qualificação e formação continuada destes profissionais, visando garantir a agilização da regularização fundiária das terras e dos territórios dos povos e comunidades tradicionais.

\section{PROPOSTA 6}

Assegurar o direito a uma educação contextualizada, que:

(a) Garanta o protagonismo dos povos e comunidades tradicionais (reconhecidos e não-reconhecidos) na qualificação e formação continuada e diferenciada de educação e de alunos na educação básica ao ensino superior, em cumprimento às 
leis $10639 / 03$ e $11.645 / 08$;

(b) Efetivar a educação do campo, pública, gratuita e de qualidade, em todos os níveis e modalidades de ensino (infantil, fundamental, médio, técnico e superior), garantindo acesso e permanência na escola, superando o analfabetismo, por meio da implementação dos marcos regulatórios específicos de educação no e do campo (diretrizes operacionais para a educação básica nas escolas do campo, diretrizes complementares/2008, decreto $7352 / 2010$ ), bem como reconhecer e financiar as escolas dos acampamentos (escolas itinerantes) e centros familiares de formação por alternância (CEFFAS); regulamentar os cursos de licenciatura em educação do campo e a habilitação técnica em agroecologia, viabilizando a sua inclusão nos concursos públicos, por meio de editais específicos;

(c) Criar, ampliar e efetivar cursos em instituições públicas e sociais para a formação dos jovens em relação ao meio ambiente, com foco nas praticas sustentáveis adequadas para cada região, qualificando para sua atuação, com financiamento prioritário do governo federal para projetos, gerando renda para os jovens que participam dos cursos.

\section{EIXO 3 - DIREITO À EXPERIMENTAÇÃO E QUALIDADE DE VIDA}

\section{PROPOSTA 1}

Garantir a não-privatização e o fortalecimento do SUS integralmente nas demandas da Juventude (de 15 a 29 anos), considerando o princípio da equidade, promovendo sua divulgação ao público jovem, por meio das diversas mídias, com linguagem contextualizada, tendo como base a carta dos direitos dos usuários do SUS, ampliando unidades básicas de saúde nas áreas periféricas, rurais, indígenas, quilombolas e ribeirinhas; garantir acesso das mulheres jovens aos exames preventivos e à vacina gratuita contra o HPV, com atendimento humanizado, garantindo o acesso aos medicamentos, sendo este de forma segura e racional, bem como o acesso à assistência farmacêutica e psicológica nos serviços de saúde; e a contratação de profissionais devidamente capacitados e hebiatras para atender os jovens da cidade e do campo. Implantar centros especializados de tratamento e reabilitação de agravos físicos e/ou psicossociais custeados pelo SUS, inclusive nos municípios de pequeno e médio porte. Garantir espaço permanente para a juventude nos conselhos nacional, estadual e municipais de saúde.

\section{PROPOSTA 2}

Ampliação, diversificação, criação e interiorização, em todas as esferas públicas (federal, estadual, distrital e municipal), dos programas Bolsa Atleta, Segundo Tempo, Mais Educação/MEC e PELC (Programa de esporte e lazer na cidade) e criação, ampliação e conservação de equipamentos esportivos em todo o País (escolas e espaços públicos) - Praça da Juventude, PEC, ginásios poliesportivos e quadras cobertas, campos de várzea e piscinas olímpicas, CAJU/PI (Centro de apoio à juventude), entre 
outras experiências de sucesso. Garantir a participação dos jovens na definição do modelo de equipamentos a serem construídos e a gestão democrática dos mesmos, por meio da formação de comissão de usuários, definindo o uso dos equipamentos e sua programação.

\section{PROPOSTA 3}

Implementar programas que destinem no orçamento das esferas federal, estaduais e municipais, verbas para a construção e implementação de centros que atendam a juventude, sendo estes espaços de convivência e de desenvolvimento de atividades esportivas, recreativas, culturais e sócioeducativas, no campo e na cidade. Tais espaços deverão contar com: equipe multiprofissional que tenha formação continuada, podendo haver parcerias entre sociedade civil e organizações estudantis, entidades de classe, organizações governamentais, lideranças e associações comunitárias e demais representações sociais. A ação de projetos e programas federais, estaduais e municipais nos centros, captação de recursos públicos para o pagamento de bolsas, funcionários e despesas para a manutenção do espaço físico de convivência da juventude, sendo $70 \%$ do governo federal, $20 \%$ do governo estadual e $10 \%$ do governo municipal. Integrar a implementação do programa nacional de banda larga, garantido o acesso à banda larga gratuita e de qualidade, com velocidade mínima de 1 Mega, para todo País, priorizando as comunidades menos favorecidas e a zona rural, garantindo, também, capacitação para os que irão utilizar o serviço.

\section{PROPOSTA 4}

Criar instâncias institucionalizadas na Área Técnica de Saúde de Adolescentes e Jovens e no Comitê Técnico de Saúde da População Negra, bem como em secretarias estaduais e municipais de saúde, que promovam o debate acerca da saúde da juventude negra, orientados pela implantação da Política Nacional de Saúde Integral da População Negra nos estados, municípios e o Distrito Federal, garantindo a equidade, um dos princípios do SUS, e promovendo o acesso e o acolhimento com equidade da juventude brasileira.

\section{EIXO 04 - DIREITO À DIVERSIDADE E À VIDA SEGURA}

\section{PROPOSTA 1}

Fomentar ações de reinserção sócioafetiva dos jovens do sistema sócioeducativo e do sistema prisional na família e na sociedade, ampliando programas de elevação da escolaridade, capacitação profissional, inserção e reinserção no mercado de trabalho e/ou medidas alternativas para a geração de emprego e renda, bem como incentivar a inclusão da modalidade de justiça restaurativa na lei processual penal como procedimento padrão. Essas ações envolveriam: incentivar, no âmbito dos governos estaduais, a criação de cotas nas empresas privadas e reserva de vagas no poder público, com sigilo das informações pessoais; propor a extinção do requerimento de antecedentes criminais para seleções públicas; atuar no tratamento de reabilitação de jovens dependentes químicos e evitar uma política de repressão, garantindo a efetivação dos direitos humanos e de políticas de reinserção social, alem de garantir e ampliar o 
orçamento do PRONASCI, assegurando maiores investimentos nas políticas focadas na juventude, tais como os projetos Farol, PLANSEQ/AFRO, PROTEJO, microprojetos mais culturas, formação policial, entre outros.

\section{PROPOSTA 2}

Implementar uma política transversal para os jovens com deficiência, garantindo educação inclusiva, atendimento em saúde/reabilitação, qualificação para entrada no mercado de trabalho e geração de renda, entre outras iniciativas, enfrentando o preconceito e a discriminação, promovendo a acessibilidade e a participação desses jovens em programas, projetos e ações governamentais em todos os municípios brasileiros.

\section{PROPOSTA 3}

Implementar, imediatamente, e fiscalizar, à luz das resoluções do $1^{\circ}$ ENJUNE (Encontro Nacional de Juventude Negra), o Plano Nacional de Enfrentamento à Mortalidade da Juventude Negra, efetivando a promoção da igualdade racial e o combate ao racismo, por meio de projetos sociais e educativos, saúde pública e segurança, com a finalidade de combater a mortalidade, homicídios e violência de qualquer natureza (física, simbólica, verbal, e psicológica) contra a juventude negra e os povos e comunidades tradicionais.

\section{PROPOSTA 4}

Implementar o Plano Nacional de Saúde Integral da População LGBT, que supere as vulnerabilidades da população de 15 a 29 anos em todos os aspectos de saúde, com principal preocupação para as especificidades de gênero, orientação sexual e identidade de gênero cor/raça, dos povos tradicionais e população de rua, considerando os graves impactos na saúde mental dos adolescentes e jovens LGBT que sofrem as diversas formas de violência, em razão de sua orientação sexual e identidade de gênero, garantido a criminalização da homofobia, a fim de diminuir a violência cometida contra esta parcela da população. Respeitar os direitos sexuais e reprodutivos de jovens que vivem com HIV/AIDS, por meio de atendimento por profissionais qualificados e humanizados, que respeitem a sexualidade e o nome com o qual cada um quer ser identificado (nome social). Envolver a Secretaria Nacional de Juventude, Ministério da Saúde, Ministério do Desenvolvimento Social e Combate à Fome, em parceria com a sociedade civil.

\section{PROPOSTA 5}

Descriminalizar e legalizar o aborto, situando-o como um grave problema de saúde pública; garantir o atendimento humanizado às mulheres jovens em situação de abortamento e a efetivação do serviço público de aborto legal em todas as unidades da Federação; promover os direitos sexuais e reprodutivos da juventude, tais como a 
distribuição de preservativos femininos e da pílula do dia seguinte no sistema único de saúde e nas farmácias populares.

\section{PROPOSTA 6}

Respeitar a Diversidade Religiosa, criando e efetivando um Plano Nacional de Combate à Intolerância Religiosa, a ser formulado por meio de debate entre poder público e sociedade civil, por suas diversas formas de interação, garantindo-se os princípios de equidade, a representatividade da pluralidade de religiões e crenças. Com isso, visa-se à efetivação dos princípios constitucionais de laicidade do Estado e de liberdade de consciência, culto e crença.

\section{EIXO 5 - DIREITO À PARTICIPAÇÃO}

\section{PROPOSTA 1}

Para reafirmarmos o Conselho Nacional de Juventude, quanto à sua diversidade $\mathrm{e}$ representatividade, é necessário incorporar o máximo de movimentos e entidades que tenham suas ações nacionalmente voltadas para a juventude. Os membros da sociedade civil no Conselho Nacional de Juventude serão representantes de entidades e movimentos de caráter nacional, escolhidos em processo seletivo. Configuram-se como entidades e movimentos de caráter nacional aquelas que atuem no mínimo em 7 (sete) estados ou 3 (três) regiões. Poderão candidatar-se as entidades e movimentos que se enquadrarem em uma das seguintes categorias:

(a) redes e articulações de juventude que atuem na defesa e promoção dos direitos da juventude ( $2 / 3$ do Conjuve);

(b) organizações mistas (com jovens e não-jovens), de caráter sindical, associativo, profissional ou de classe, que atuem na defesa e promoção dos direitos da juventude ( $1 / 3$ do Conjuve).

\section{PROPOSTA 2}

Os conselhos de Juventude no Brasil devem se constituir considerando as seguintes características/atribuições:

(a) Representar a Juventude no sentido de promover melhorias, qualidade de vida e acesso a ações e projetos diversificados;

(b) Com caráter deliberativo e fiscalizador, com cotas de $3 / 5$ de jovens;

(c) Com entidades que atuem no segmento de juventude;

(d) Com obrigatoriedade de inserção juvenil;

(e) Com alternância de sociedade civil e poder público na presidência;

(f) Com garantia de espaço de participação nos conselhos de juventude para os estudantes, LGBT, mulheres, negros, pessoas com deficiência, entidade de 
bairro, trabalhadores, jovens do campo e de comunidades indigenas, quilombolas, de terreiros e povos tradicionais, entre diversos outros segmentos juvenis;

(g) Com sede própria;

(h) Acompanhados de Fóruns Municipais e/ou Territoriais e demais organizações de suporte/apoio ao conselho;

(i) Subdivididos por conselhos regionais, de acordo com o porte do município, cujos membros da sociedade civil sejam eleitos em fóruns, assembléias e outros coletivos específicos de juventude, e não indicados, salvo quando não houver um fórum especifico de juventude;

(j) Com dotação orçamentária específica prevista em LDO/LOA e no PPA;

(k) Com prazo de mandato definido por lei, e, onde ainda não houver conselhos, que seja fomentada e incentivada a sua criação;

(1) Com $3 / 4$ de participação da sociedade civil, contemplando a participação dos povos tradicionais e comunidades indigenas.

\section{PROPOSTA 3}

Garantir a aprovação do sistema nacional de financiamento de juventude no estatuto da juventude e de um fundo nacional de juventude, com receita direta do Tesouro Nacional, além de garantir que os demais entes federativos criem seus respectivos fundos para ações voltadas às políticas públicas de juventude, destinando uma receita específica, de acordo com a realidade de cada ente, garantindo que $o$ gerenciamento e a fiscalização destes recursos sejam feitas pelos conselhos de juventude.

BRASIL. Secretaria Nacional de Juventude. $2^{\text {a }}$ Conferência Nacional de Juventude. Disponível em: <http://juventude.gov.br/conferencia/2aconferencia-nacional-de-juventude/>. Acesso em: 10.set.2015. 


\section{ANEXO K - COMO FUNCIONAM OS GRUPOS DE TRABALHO $3^{a}$ CONFJUV}

\section{COMO FUNCIONAM OS GRUPOS DE TRABALHO}

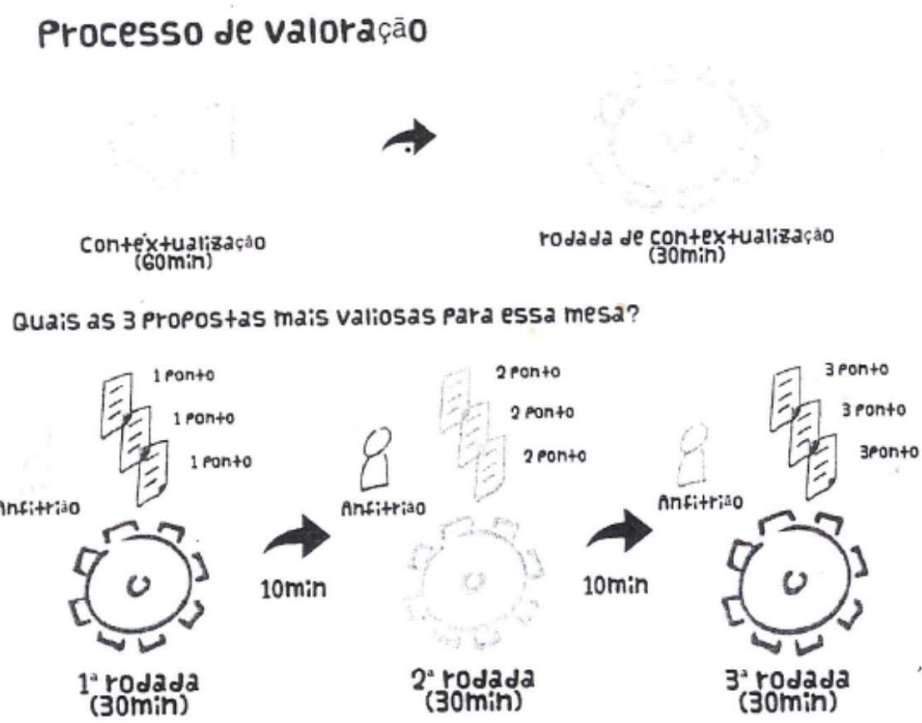

\section{Passo a Passo}

$\left.1^{\circ}\right)$ Escolha 0 seu Tema e sente na mesa com a cor dele.

\section{Durante a rodada de contexiualizacão}

$2^{\circ}$ ) Eleja 0 anfitrião de sua mesa.

$3^{\circ}$ ) Escute a contextualização do seu tema.

$\left.4^{\circ}\right)$ Leia as propostas. Discuta o tema a partir do que você leu e ouviu.

$\left.5^{\circ}\right)$ Ao final de 30 minutos, mude de mesa. Exceto 0 anfitrião

\section{Durante as rodadas de discussão}

Interaja com outros grupose argumente suas ideias com novas pessoas.

$\left.3^{\circ}\right)$ Discuta as propostas.

$4^{\circ}$ ) Escolha as 3 propostas mais valiosas.

$5^{\circ}$ ) Ao final de 30 minutos entregue as três propostas ao moderador e mude de mesa. 


\section{ROTEIRO DA MESA DE DIÁLOGO}

\section{RODADA DE CONTEXTUALIZAÇÃO}

1. ESCOLHER O ANFITRIĀO

Anfitriào a a pessoa ca mésa que ficara responsavel de registrar e compartilhar as discussōes e escolhas do grupo com as outras pessoas que rào se sentar à mesa. depois de uma rodada $O$ anfitriào é escolhido por consenso e não muda de mesa de uma rodada pra outra.

2. ESCUTAR A CONTEXTUALIZAÇĀO

Contextualizaçào e o momento dos participantes nivelarem iníormaçōes sobre o tema em discussào, a partir da fala de 2 convidados

3. LER AS PROPOSTAS E CONVERSAR SOBRE A CONTEXTUALIZAÇĀO

Nesse momento os participantes da mesa irão ler as propostas e conversar sobre o que foi apresentado.

4. MUDAR DE MESA

Depois da conversa e hora de encontrar outros participantes e continuar a conversa sobre o tema com novas pessoas. Afina!, estamos aqui para interagir com opiniões diferentes. ( $O$ anfitrião não muda de mesa).

G

\section{RODADADE DISCUSSÃO 1,2 e 3}

1. ESCUTAR O ANFITRIÃO

Nesse momento 0 anfitrião recebe os novos participantes na mesa e compartilha quais foram 3 proposta mais valiosas para a mesa anterior e porque elas foram escolhidas.

2. ESCOLHER NOVO ANFITRIÃO

Para registrar e compartilhar as discussōes e escolhas de propostas. $O$ anfitrião não muda de mesa de uma rodada para a outra.

3. QUAIS AS 3 PROPOSTAS MAIS VALIOSAS PARA ESSA MESA?

Nesse momento os participantes da mesa iräo discutir e escolher 3 propostas sobre otima em discussão na mesa.

4. MUDAR DE MESA

Depois da conversa e hora de encontrar outros participantes e continuar a conversa sobre o tema com novas pessoas

\section{REGRAS:}

- Proposta nova só poderá ser elaborada na l' rocada, se não, a proposta não conseguiria chegar a outras mesas para ser discutida.

- A cada rodada as propostas recebem maior pontuação, pois são mais discutidas e mais argumentadas.

- A cada rodada um anfitrião e eleito para compartithar a discussāo na proxima rodada.

TODAS AS RODADAS TEM DURAÇÃO DE 30 


\section{ANEXO L - RESOLUÇÕES APROVADAS NA $3^{\mathrm{a}}$ CONFJUV}

\section{RESULTADO: EDUCAÇÃO}

\begin{tabular}{|c|c|c|}
\hline $\mathrm{N}^{\circ}$ & PROPOSTAS & PONTOS \\
\hline 10 & $\begin{array}{l}43 \text { - Garantir o financiamento público para a manutenção e ampliação das escolas famílias agrícolas, } \\
\text { possibilitando ofertar PRONATEC - campo, trabalhando a pedagogia da alternância, nas esferas estaduais e } \\
\text { federais. E implementando uma política de assistência estudantil que garanta bolsa de permanência e transporte } \\
\text { escolar para seus estudantes, assim como sejam lançadas ações de implementação de centros de permanência de } \\
\text { referência cultural, esporte, lazer e telecomunicações dentro de seus espaços físicos. }\end{array}$ & \\
\hline & $\begin{array}{l}392^{*} \text { - Reformar a grade curricular, PPPS, material didático e estrutura física de instituições de ensino } \\
\text { fundamental e médio que estejam dentro ou próximas de territórios de povos e comunidades tradicionais e } \\
\text { comunidades rurais, garantindo que tal reforma seja feita em conjunto com a comunidade, atendendo as } \\
\text { prerrogativas da Educação do Campo, das leis } 10639 / 03,11.645 / 08 \text { e do decreto } 6040 / 07 \text {, garantindo também } \\
\text { concursos públicos priorizando a contratação de profissionais da própria comunidade nestas instituições de } \\
\text { ensino. }\end{array}$ & \\
\hline & $\begin{array}{l}52 \text { - Regulamentação e real implementação dos } 10 \% \text { do PIB para a Educação, com a destinação de } 50 \% \text { do Fundo } \\
\text { Social e } 75 \% \text { dos Royalties do Petróleo para a garantir a efetivação do plano nacional de educação e do } \\
\text { financiamento nele expresso afim de elevar a qualidade social da Educação em todos os níveis, etapas e } \\
\text { modalidades. }\end{array}$ & \\
\hline & $\begin{array}{l}39 \text { - Criar política nacional de assistência estudantil ao jovem, incluindo os beneficiários do PROUNI e FIES, com } \\
\text { implementação de moradias, restaurantes, creches e atendimento a todas as necessidades das pessoas com } \\
\text { deficiência, e com o estabelecimento de lei federal especifica e fundo específico que desvincule aos auxílios e } \\
\text { benefícios de contrapartidas e que tenham um processo de concessão de bolsas permanência desburocratizado e } \\
\text { valores atualizados. }\end{array}$ & \\
\hline & $\begin{array}{l}36 \text { - Garantir a ampliação do ensino superior com o aumento de vagas (novas universidade, novos campi, PROUNI, } \\
\text { FIES) e da abrangência contemplando área rural, comunidades tradicionais e o interior, com ampliação das cotas } \\
\text { sociais e raciais e a garantia de realização do ENEM em todos os municípios. }\end{array}$ & \\
\hline & $\begin{array}{l}69 \text { - Reformulação do Ensino Básico e Médio desde a matriz curricular à formação dos professores, } \\
\text { democratizando e humanizando as escolas, incluindo debates como: gênero, igualdade, justiça social e liberdade; } \\
\text { ampliando a carga horária de disciplinas tais como: filosofia, sociologia e história, possibilitando, assim, o senso } \\
\text { crítico e político dos estudantes. }\end{array}$ & \\
\hline & $\begin{array}{l}68 \text { - Incorporar nas grades curriculares das escolas públicas e privadas, conteúdos e temáticas que são vivenciadas } \\
\text { no dia-a-dia por jovens da sociedade brasileira, trazendo interação com o contexto educacional, de caráter } \\
\text { teórico-prático, questões como Ética e Cidadania, saúde alimentar, planejamento econômico, diversidade sexual, } \\
\text { de gênero, racial, social e de credo, preconceito e a discriminação, direito à educação e à comunicação, Direito } \\
\text { Constitucional, Estatuto da Criança e do Adolescente (ECA), Ciência Política, Estatuto da Juventude, educação em } \\
\text { Direitos Humanos, Informática, Filosofia, língua de sinais e garantir o ensino das Histórias e Culturas Afro- } \\
\text { brasileiras, Africanas e Indígenas, em cumprimento das Leis } 10.639 \text { e } 11.645 \text {. }\end{array}$ & \\
\hline & $\begin{array}{l}71 \text { - Reformulação do currículo e do ambiente físico que a escola proporciona, no intuito de adequação de } \\
\text { modelos didáticos que contextualizem a realidade da inserção da juventude negra, LGBT, povos e comunidades } \\
\text { tradicionais, rural, pessoa com deficiência; e propor atividades extracurriculares, tais como atividades esportivas, } \\
\text { artísticas e culturais que levaram em consideração as competências e habilidades dos e das estudantes. Além, de } \\
\text { criar estratégias que aproximem a família e ou responsáveis para maior participação no cotidiano escolar para } \\
\text { que, desta maneira seja estabelecida uma relação entre a comunidade, professores, alunos, responsáveis, } \\
\text { incluindo a participação como elemento condicionante da inclusão ou continuidade em programas sociais. }\end{array}$ & \\
\hline $\mathbf{g}^{0}$ & $\begin{array}{l}48 \text { - Efetivar as políticas públicas da educação das relações étnicos raciais, com base nas leis } 10.639 \text { e } 11.645 \text {, as } \\
\text { relações de gênero e demais diversidades, com o caráter de fortalecer as diretrizes curriculares nacionais para o } \\
\text { fomento a cultura da política e cidadania. Bem como, a garantia de implementação de equipes multiprofissionais } \\
\text { nas redes de educação das instâncias municipais, estaduais, e federais. Com a participação dos profissionais de } \\
\text { psicologia, pedagogia, assistência social e interprete. Potencializando o apoio e orientação e acompanhamento } \\
\text { dos/as estudantes e comunidades, assegurando a disseminação de tecnologias assistivas, Braile, Libras, a partir } \\
\text { de: inclusão de Libras como disciplina obrigatória em todos os cursos superiores (bacharelados, licenciaturas e } \\
\text { tecnológicos); inclusão da disciplina de Libras nos currículos das escolas municipais, estaduais e federais, e } \\
\text { implantação da Graduação em Letras Libras nas universidades estaduais para a formação de professores de Libras } \\
\text { (licenciatura) e tradutores/interpretes (bacharelado) e inclusão de braile como opinativa (licenciatura). }\end{array}$ & \\
\hline
\end{tabular}




\section{RESULTADO: SAÚDE}

\begin{tabular}{|c|c|c|}
\hline $\mathrm{N}^{\circ}$ & PROPOSTAS & PONTOS \\
\hline $1^{0}$ & $\begin{array}{l}188 \text { - Promover campanhas sobre os danos à saúde causados pelo uso de agrotóxicos, } \\
\text { principalmente nas escolas do campo, e apresentando a agroecologia como alternativa de } \\
\text { cultivo de alimentos saudáveis para a população. }\end{array}$ & \\
\hline $2^{0}$ & $\begin{array}{l}199 \text { - Implantar o programa de saúde da Juventude, com garantia de acesso das juventudes } \\
\text { rurais e comunidades tradicionais, fomentando a aquisição de ambulâncias e ampliação do } \\
\text { quadro médico, para atendimento específico de urgência e emergência, além de fortalecer } \\
\text { através da RAPS nos CAPS/AD, CAPS/ADI e consultórios na rua, com equipe interdisciplinar, } \\
\text { tendo o viés da saúde mental, redução de danos e educação em saúde, promovendo a } \\
\text { intersetorialidade das políticas de saúde, assistência social, educação, trabalho, direitos } \\
\text { humanos entre outras. }\end{array}$ & \\
\hline & $\begin{array}{l}175 \text { - Garantir atendimento psicossocial e de saúde especializado para a juventude LGBT } \\
\text { (lésbicas, gays, bissexuais, travestis, transexuais e trangêneros) nas Unidades de Saúde da } \\
\text { Família (USFs), Centros de Referência em Assistência Social (CRAS) e Centros de Referência } \\
\text { Especializados em Assistência Social (CREAS), com profissionais sensíveis e preparados. }\end{array}$ & \\
\hline & $\begin{array}{l}191 \text { - Garantir a participação da juventude nos espaços de controle social da saúde (Conselhos } \\
\text { e Conferências) para que pensem estratégias de políticas de prevenção da saúde em espaços } \\
\text { de cultura, lazer e esporte, sendo dinâmicas, agradáveis e efetivas na redução dos índices de } \\
\text { violência. }\end{array}$ & \\
\hline & $\begin{array}{l}164 \text { - Promover a saúde integral da mulher jovem, sem seguir a lógica da medicalização e } \\
\text { intervenção sobre o corpo. O sistema de saúde deve lidar com a prevenção da saúde das } \\
\text { jovens,incluindo atendimento relacionado a abortos, que hoje é a quinta causa de mortes no } \\
\text { país, o Estado deve tratar do caso como saúde pública garantindo-lhes atendimento } \\
\text { ginecológico preparado. }\end{array}$ & \\
\hline & $\begin{array}{l}187 \text { - Garantir passagem de transporte público (dez passagens diárias), assim equiparando as } \\
\text { pessoas com deficiência física aos portadores de doença crônica degenerativa com direito a } \\
\text { passagem de acompanhante. Assim como, a concessão de transporte adequado às pessoas } \\
\text { com deficiência física e doenças crônicas degenerativas para as suas atividades de saúde. }\end{array}$ & \\
\hline & $\begin{array}{l}171 \text { - Ampliar a rede de cobertura do PSF, inclusive na área rural e comunidades tradicionais, } \\
\text { com equipes multiprofissionais que considerem as especificidades de raça/etnia, orientação } \\
\text { sexual e identidade de gênero e que visitem pelo menos três vezes por semana. }\end{array}$ & \\
\hline & $\begin{array}{l}195 \text { - Instituir e ampliar políticas públicas para a humanização com capacitação e sensibilização } \\
\text { dos profissionais de saúde no tocante ao atendimento das juventudes em todos os níveis de } \\
\text { complexidade do SUS. }\end{array}$ & \\
\hline ğo $^{\circ}$ & $\begin{array}{l}193 \text { - Garantir a inserção do Programa de Saúde na Escola (PSE) no projeto político-pedagógico } \\
\text { do Ministério da Educação, em articulação com o Ministério da Saúde, cobrando dos } \\
\text { municípios, o cumprimento de metas pactuadas e eventual aplicação de penalidades para o } \\
\text { não comprimento das mesmas, efetivando o Artigo } 19 \text { da Lei } 8080 / 90 \text {, sobre a promoção, } \\
\text { prevenção, proteção à saúde de forma integral, fortalecendo temáticas como: identidade de } \\
\text { gênero, alimentação saudável, direitos sexuais, saúde reprodutiva, drogas e primeiros } \\
\text { socorros. }\end{array}$ & \\
\hline
\end{tabular}




\section{RESULTADO: TRABALHO}

\begin{tabular}{|c|c|c|}
\hline $\mathrm{N}^{0}$ & PROPOSTAS & PONTOS \\
\hline $1^{0}$ & $\begin{array}{l}73 \text { - Fortalecer os empreendimentos e coletivos de juventude da agricultura familiar, pesca } \\
\text { artesanal e demais atividades produtivas do campo e da cidade com agroindústrias, bem } \\
\text { como, incentivar a formação de novos coletivos, garantindo o acesso ao crédito a ATER e a } \\
\text { comercialização, visando a promoção da economia solidária como estratégia para garantia do } \\
\text { bem viver, do trabalho digno e da renda para a juventude. }\end{array}$ & \\
\hline & $\begin{array}{l}96 \text { - Construir e ampliar as unidades de ensino médio, profissionalizante, técnico e superior, } \\
\text { juntamente com a ampliação da quantidade de Bolsas de pesquisa e extensão e das vagas nas } \\
\text { parcerias com sistema S, nos programas como: menor aprendiz, jovem aprendiz, Pronatec, } \\
\text { Pronacampo, Projovem urbano, Projovem rural, SISUTEC, SISU, Prouni e demais programas. E } \\
\text { que a ampliação considere as áreas periféricas e rurais, contemplando a realidade de cada } \\
\text { região, fomentando parcerias com o poder público e privado a fim de garantir vagas de } \\
\text { emprego e alternativas de renda. }\end{array}$ & \\
\hline & $\begin{array}{l}94 \text { - Implementar políticas públicas de juventude de acordo com o Plano Nacional de Trabalho } \\
\text { Decente para a Juventude. }\end{array}$ & \\
\hline & $\begin{array}{l}90 \text { - Garantir o acesso ao } 1 \text { 을 emprego com qualidade; Reduzir a jornada de trabalho para } 40 \\
\text { horas semanais; Proibir a terceirização em todas as suas formas }\end{array}$ & \\
\hline & $\begin{array}{l}103 \text { - Criação de centro técnico profissionalizante rural de acordo com sua região, } \\
\text { proporcionando trabalho e renda, garantindo a permanência do jovem rural no campo, } \\
\text { incentivando a produção e comercialização da agricultura familiar, assim como outros, meios } \\
\text { de geração de renda, priorizando a cultura local. }\end{array}$ & \\
\hline & $\begin{array}{l}95 \text { - Garantir aos jovens em cumprimento de penas ou medidas socioeducativas que sejam } \\
\text { direcionados a centros de formação que transformará a pena de reclusão em pena de } \\
\text { qualificação. O tempo de pena seria cumprido em um abrigo submetidos a aprender um oficio, } \\
\text { e assim que terminasse a pena estariam qualificados e seriam encaminhado direto para o } \\
\text { mercado de trabalho. o projeto poderia acontecer em parceria do estado e com empresas } \\
\text { privadas interessadas em mão de obra jovem e qualificada. }\end{array}$ & \\
\hline & $\begin{array}{l}74 \text { - Desburocratizar as políticas públicas que garantam o acesso a terra, habitação, } \\
\text { infraestruturas de produção, Ater, educação do campo, cidade e comunidades tradicionais. }\end{array}$ & \\
\hline & $\begin{array}{l}84 \text { - Garantir uma cota de } 20 \% \text { de contratação de jovens egressos dos sistemas prisionais e } \\
\text { medidas socioeducativas como um dos requisitos para seleção no processo licitatório de } \\
\text { empresas prestadoras de serviços e executora de obras a serem contratadas pelos governos } \\
\text { municipais, estaduais e federal. }\end{array}$ & \\
\hline$g^{\circ}$ & $\begin{array}{l}87 \text { - Potencializar ações do Ministério do Trabalho e Emprego para ampliação do percentual de } \\
\text { vagas direcionadas aos jovens respeitando as condições de trabalho decente através da } \\
\text { Política Nacional de Trabalho, garantindo a criação de uma plataforma on-line de divulgação e } \\
\text { acompanhamento para estes fins. }\end{array}$ & \\
\hline
\end{tabular}




\section{RESULTADO: CULTURA}

\begin{tabular}{|c|c|c|}
\hline $\mathrm{N}^{0}$ & PROPOSTAS & PONTOS \\
\hline & $\begin{array}{l}395 \text { - Garantir a construção, manutenção, ampliação e requalificação dos equipamentos culturais, promovendo a } \\
\text { acessibilidade, sustentabilidade e participação social nas periferias, distritos, zonas rurais, comunidades } \\
\text { tradicionais, povoados e assentamentos, descentralizando as ações de juventude e oferecendo espaços } \\
\text { adequados, bibliotecas, sob consultoria especializada, para as diversas linguagens culturais: teatro, audiovisual, } \\
\text { hip hop, dança, artes, artesanato, música, poesia dentre outras. Viabilizando a criação e fomento de grupos } \\
\text { culturais tais como artesãos, grupos de dança, teatro e as demais expressões artísticas e culturais, priorizando os } \\
\text { artistas municipais e a promoção de atividades itinerantes descentralizadas, incentivando programas culturais em } \\
\text { escolas e associação de moradores, bem como a criação de editais sob a forma de prêmios (com prestações de } \\
\text { contas facilitada E ESPECíFICA PARA PCTs). }\end{array}$ & \\
\hline $2^{0}$ & $\begin{array}{l}217 \text { - Estabelecer uma rede de juventude e cultura por meio de um mapeamento cultural, que possa garantir um } \\
\text { processo formativo em linguagens artísticas diversas, bem como a formação em áreas técnicas que garantam a } \\
\text { qualificação de jovens para criação e execução de projetos culturais, e que de forma autônoma possa criar uma } \\
\text { importante rede de intercâmbio cultural em conexão com todos os territórios. }\end{array}$ & \\
\hline $3^{0}$ & $\begin{array}{l}224 \text { - Instituir financiamento para a produção cultural, circulação e capacitação de jovens, por meio de editais } \\
\text { específicos, de forma a incentivar suas expressões, considerando a diversidade (urbano, rural, comunidades } \\
\text { tradicionais, LGBT e deficientes), o fortalecimento de seus grupos e possibilitar sua profissionalização no âmbito } \\
\text { da economia criativa. }\end{array}$ & \\
\hline & $\begin{array}{l}228 \text { - Criação de bolsa especificamente voltada para a juventude artística ( } 15 \text { a } 29 \text { anos) como previsto no } \\
\text { estatuto da juventude, possibilitando as ferramentas necessárias para o incentivo e a criação, para o } \\
\text { financiamento de produção e promoção de sua obra, disponibilidade de material de pesquisa, instrumentos, } \\
\text { ferramentas de ofício, além de reservar um espaço em material publico voltado à divulgação, como jornais, sites, } \\
\text { revistas; de universidades federais ou órgãos públicos. }\end{array}$ & \\
\hline & $\begin{array}{l}230 \text { - Catalogar e acompanhar tradições culturais locais e regionais, instituindo incentivo financeiro regular } \\
\text { (orçamento anual) para ações que promovam a preservação de tais identidades e a difusão dessas expressões } \\
\text { culturais. }\end{array}$ & \\
\hline & $\begin{array}{l}221 \text { - Estabelecer a destinação legal de no mínimo } 2 \% \text { do orçamento líquido municipal e estadual para Fundos de } \\
\text { Cultura Municipal e Estadual, com a abertura de editais públicos para financiamento de atividades, projetos e } \\
\text { infra-estrutura (nos centros, periferias e áreas rurais) garantindo divulgação, acessibilidade, pluralidade, e } \\
\text { descentralização, conforme demandas da sociedade civil (garantindo, inclusive editais específicos para a } \\
\text { juventude). Para gestão do Fundo é necessário a regulamentação dos Conselhos de Cultura, com composição } \\
\text { majoritariamente por representantes da sociedade civil eleitos diretamente, considerando também um } \\
\text { representante da juventude, e com caráter deliberativo e de acompanhamento da abertura de editais, aplicação } \\
\text { dos recursos e prestação de contas. }\end{array}$ & \\
\hline & 214 - Exigir a aplicação do mínimo de $2 \%$ do PIB para cultura e aplicação do Plano Nacional de Cultura. & \\
\hline $8^{0}$ & $\begin{array}{l}212 \text { - Implementar o projeto "Cinema nos Bairros" que consiste em aproximar a juventude local da linguagem } \\
\text { audiovisual a partir de: a) oficinas e cursos na área de audiovisual b) sessões gratuitas de cinema c) incentivo e } \\
\text { estrutura para a produção audiovisual no bairro d) circulação de filmes produzidos por jovens de periferia e) } \\
\text { promoção de estratégias de discussão política que aborde a perspectiva da cultura na construção da cidadania f) } \\
\text { a criação de redes entre os e as jovens que estão trabalhando e produzindo na área do audiovisual g) intercâmbio } \\
\text { entre as experiências dos bairros que contarão com o projeto. Portanto, a proposta prevê a viabilização de } \\
\text { espaços culturais, com gestão comunitária e com protagonismo dos e das jovens, que sirvam como zonas de } \\
\text { circulação de conhecimentos e experiências entre jovens no que tange à produção audiovisual }\end{array}$ & \\
\hline & $\begin{array}{l}395 \text { - Garantir a construção, manutenção, ampliação e requalificação dos equipamentos culturais, promovendo a } \\
\text { acessibilidade, sustentabilidade e participação social nas periferias, distritos, zonas rurais, comunidades } \\
\text { tradicionais, povoados e assentamentos, descentralizando as ações de juventude e oferecendo espaços } \\
\text { adequados, bibliotecas, sob consultoria especializada, para as diversas linguagens culturais: teatro, audiovisual, } \\
\text { hip hop, dança, artes, artesanato, música, poesia dentre outras. Viabilizando a criação e fomento de grupos } \\
\text { culturais tais como artesãos, grupos de dança, teatro e as demais expressões artísticas e culturais, priorizando os } \\
\text { artistas municipais e a promoção de atividades itinerantes descentralizadas, incentivando programas culturais em } \\
\text { escolas e associação de moradores, bem como a criação de editais sob a forma de prêmios (com prestações de } \\
\text { contas facilitada E ESPECÍFICA PARA PCTs). }\end{array}$ & \\
\hline
\end{tabular}




\section{RESULTADO: PARTICIPAÇÃO}

\begin{tabular}{|c|c|c|}
\hline $\mathrm{N}^{0}$ & PROPOSTAS & PONTOS \\
\hline $1^{0}$ & $\begin{array}{l}32 \text { - Garantir a implantação do Sistema Nacional de Juventude composto por órgãos gestores, } \\
\text { conselhos e fundos de públicas de juventude, nas três esferas administrativas. O fundo nacional de } \\
\text { juventude funcionará com repasses fundo a fundo definido percentualmente entres os três entes } \\
\text { federados para direcionar as políticas e ações para a juventude em âmbito nacional, estadual e } \\
\text { municipal. }\end{array}$ & \\
\hline & $\begin{array}{l}\text { 391* - Garantir a participação de no mínimo } 30 \% \text { de jovens nos conselhos consultivos e deliberativos } \\
\text { no âmbito Federal, Estadual e Municipal considerando a paridade de gênero, recorte étnico racial e } \\
\text { cotas para PCTs e LGBTs. Bem como estimular a participação dos jovens no legislativo e judiciário. }\end{array}$ & \\
\hline & $\begin{array}{l}802 \text { - Garantir dentro dos parlamentos e conselhos setoriais a cota de } 25 \% \text { considerando que a } \\
\text { populaçãoo jovem no Brasil, corresponde } 1 / 4 \text {, de acordo com o IBGE, respeitando a paridade de gênero, } \\
\text { racial, LGBTS, comunidades e povos tradicionais }\end{array}$ & \\
\hline & $\begin{array}{l}804 \text { - Garantir a participação de no mínimo } 20 \% \text { de jovens nos espaços públicos, em todos os } \\
\text { conselhos consultivos e deliberativos das } 3 \text { esferas, observando as cotas para negrosm mulheres, Igbt e } \\
\text { indígenas, assegurando pela roforma política os mesmo } 20 \% \text { das cadeiras do poder legislativo para a } \\
\text { juventude. }\end{array}$ & \\
\hline & $\begin{array}{l}35 \text { - Garantir a criação de Observatórios de Juventudes para a promoção de pesquisas e estudos sobre } \\
\text { temas relevantes em nível local, gerando uma plataforma digital para a divulgação dos dados } \\
\text { produzidos por todos os institutos de pesquisa, oficiais ou não, e universidades, dando publicidade aos } \\
\text { dados e informações que amparem o desenvolvimento de políticas públicas. }\end{array}$ & \\
\hline & $\begin{array}{l}\text { 3. Desenvolver projetos nas escolas garantindo uma metodologia com protagonismo juvenil e uma } \\
\text { perspectiva de educação cidadã, onde os jovens participem da discussão do projeto político } \\
\text { pedagógico. E, também, realizem um processo de formação social e política, através de cursos } \\
\text { complementares sobre ciência política, direitos humanos e direito constitucional, através de } \\
\text { capacitação em elaboração de projetos, através da ampliação carga horária das disciplinas de filosofia e } \\
\text { sociologia e através da inclusão na grade curricular do conteúdo de políticas públicas. Assim, se } \\
\text { conscientizando de seus direitos, deveres e qual seu papel na sociedade. }\end{array}$ & \\
\hline & $\begin{array}{l}9 \text { - Criar um canal permanente de diálogo com as juventudes da América Latina e do Caribe para } \\
\text { fortalecer a identidade regional, ampliando a cidadania ativa e unificando nossas lutas por um } \\
\text { continente fundamentado na igualdade, na justiça social e em políticas públicas transformadoras. }\end{array}$ & \\
\hline & $\begin{array}{l}33 \text { - Estabelecer a obrigatoriedade de ser instituído órgão gestor de juventude em todos os municípios, } \\
\text { podendo este ser secretaria, subsecretaria superintendência e/ou coordenadoria, dependendo da } \\
\text { realidade de cada município. Garantindo a efetividade do sistema nacional de juventude por meio da } \\
\text { criação do fundo estadual/municipal da juventude. }\end{array}$ & \\
\hline & $\begin{array}{l}24 \text { - Fomentar a criação de novos conselhos municipais e estaduais da juventude, deliberativos e } \\
\text { paritárias, e buscar o empoderamento dos conselhos já existentes, a fim de condicionar mecanismos de } \\
\text { fiscalização e pautar as políticas públicas da juventude. }\end{array}$ & \\
\hline
\end{tabular}




\section{RESULTADO: ESPORTE}

\begin{tabular}{|c|c|c|}
\hline $\mathrm{N}^{0}$ & PROPOSTAS & PONTOS \\
\hline & $\begin{array}{l}901 \text { - Fortalecimento e qualificação do esporte na escola, ampliando a participaçãoo de } \\
\text { estudantes e da comunidade, implementando a funcionalidade da escola como equipamento } \\
\text { esportivo. }\end{array}$ & \\
\hline $2^{0}$ & $\begin{array}{l}902 \text { - Criação do Fundo Nacional de incentivo ao esporte, com base orçamentaria de } 2 \% \text { do } \\
\text { PIB, fortalecendo conselhos e secretarias de esporte, para ampliar os equipamentos esportivos } \\
\text { e desenvolver programas de incentivo ao esporte, como iniciativas regionais e o Bolsa Atleta }\end{array}$ & \\
\hline & $\begin{array}{l}903 \text { - Estimular a criação de secretarias e conselhos de esporte e lazer em todos os municípios, } \\
\text { garantindo que os conselhos respeitem a diversidade esportiva e a inclusão da juventude, } \\
\text { assim, consolidando o sistema nacional de esporte e lazer. }\end{array}$ & \\
\hline & $\begin{array}{l}904 \text { - Reestruturar o programa escola aberta do governo federal para que a escola seja } \\
\text { transformada, nos finais de semana em equipamento publico de esporte e lazer para uso de } \\
\text { comunidade. }\end{array}$ & \\
\hline & $\begin{array}{l}905 \text { - Construir, reformar, ampliar, requalificar e manter equipamentos e espaços públicos } \\
\text { para a pr[atica de esportes, especialmente a dos esportes urbanos (parkour, skate, patins, } \\
\text { bikefreestyle, etc), além de ocupar e divulgar esses pespaços de esporte e lazer, garantindo a } \\
\text { acessibilidade adequada às pessoas com deficiência, com prioridade nas áreas de maior } \\
\text { vulnerabilidade social e de alto índice de extermínio da juventude, em todos os municípios e } \\
\text { zona rural, com profissionais capacitados e habilitados para atendimento nos horários } \\
\text { compatíveis com o horário livre dos trabalhadores jovens }\end{array}$ & \\
\hline & $\begin{array}{l}274 \text { - Garantir programas de financiamento aos profissionais que desenvolvem projetos de } \\
\text { incentivo ao esporte nas comunidades, visando a continuidade e o amplo acesso aos jovens. }\end{array}$ & \\
\hline & $\begin{array}{l}275 \text { - Criar ações de orientação e formalização das associações, grupos e organizações sociais } \\
\text { que promovem atividades e modalidades esportivas, assim garantindo a possibilidade de } \\
\text { acessar financiamentos públicos. }\end{array}$ & \\
\hline $8^{0}$ & $\begin{array}{l}277 \text { - Criar uma política nacional para inclusão de jovens com deficiência em práticas } \\
\text { esportivas }\end{array}$ & \\
\hline & $\begin{array}{l}285 \text { - Promover o incentivo e financiamento pelo Poder Público de eventos esportivos e de } \\
\text { lazer, que contemple diversas modalidades esportivas, que sejam realizadas também em } \\
\text { comunidades rurais assim interiorizando a prática esportiva. }\end{array}$ & \\
\hline
\end{tabular}




\section{RESULTADO: COMUNICAÇÃO}

\begin{tabular}{|c|c|c|}
\hline $\mathbf{N}^{\circ}$ & PROPOSTAS & PONTOS \\
\hline $1^{0}$ & $\begin{array}{l}239 \text { - Garantir a universalização do acesso às telecomunicações e internet } \\
\text { gratuita e de qualidade (acima de 50MB) inclusive nas áreas rurais, } \\
\text { comunidades tradicionais, por meio da expansão da infraestrutura de } \\
\text { telecomunicações e fiscalização das operadoras, da disseminação de } \\
\text { telecentros públicos, pontos de internet livre em espaços públicos, em todas as } \\
\text { escolas, e pacotes residenciais subsidiadas para a classe popular. }\end{array}$ & \\
\hline $2^{\circ}$ & $\begin{array}{l}256 / 257 \text { - Democratização da mídia modificando a legislação atual para que } \\
\text { as rádios comunitárias tenham alcance igualitário das rádios } \\
\text { comerciais.Regulamentar e democratizar a mídia do país, revendo os modelos } \\
\text { de financiamento e concessão pública de TV, a partir da atualização e } \\
\text { efetivação do marco regulatório da comunicação, respeitando a constituição de } \\
1988 \text { no que tange ao artigo } 220 \text {, revogando o caráter consultivo do Conselho } \\
\text { Nacional de Comunicação, alterando a sua composição permitindo a } \\
\text { participação paritária da sociedade civil e governo e replicando este modelo de } \\
\text { conselho no âmbito estadual e municipal. }\end{array}$ & \\
\hline $3^{\circ}$ & $\begin{array}{l}236 / 1073 \text { - Criar lei de fomento, criação de um canal e financiamento por meio } \\
\text { de fundo específico e editais públicos para mídias alternativas (rádios, TVs, } \\
\text { plataformas virtuais, dentre outros meios), incluindo todos os grupos } \\
\text { minorizados (comunidades rurais, mulheres, LGBTs, negros, povos e } \\
\text { comunidades tradicionais, deficientes etc). Ampliando assim os espaços de } \\
\text { participação dos jovens nos meios de comunicação, permitindo a manutenção, } \\
\text { capacitação e profissionalização dos jovens comunicadores na produção de } \\
\text { conteúdo e todas as expressões da juventude brasileira. }\end{array}$ & \\
\hline $4^{\circ}$ & $\begin{array}{l}\text { 1074- Viabilizar a interação das pessoas com deficiência, em respeito a LBI } \\
\text { na rede de canais abertos de televisão por meio da cobrança com mais rigor } \\
\text { do } \\
\text { cumprimento. } \\
\text { normais ferais e e critérios básicos para a promoçãa de acessibilidade das } \\
\text { pessoas com deficiência ou mobilidade reduzidas e; } \\
\text { 2) No decreto - Lei } 5.296 \text { (02/12/2004), que especifica de forma mais } \\
\text { clara como devem ser adaptadas as mensagens dos meios de comunicação } \\
\text { às pessoas com deficiência sensorial. }\end{array}$ & \\
\hline $5^{0}$ & 258 - Classificar e reduzir o tempo que estimulam a violência policial. & \\
\hline $6^{\circ}$ & $\begin{array}{l}240 \text {-Criar programa nos moldes das casas digitais e telecentros, associado a } \\
\text { um espaço virtual, que promova e garanta a acessibilidade e a inclusão digital } \\
\text { nas áreas urbanas e rurais, com capacitações que trabalhem software livre, } \\
\text { aspectos sociais e culturais e com monitores permanentes no apoio das } \\
\text { atividades. }\end{array}$ & \\
\hline $7^{0}$ & $\begin{array}{l}1070 \text { - Criação de uma plataforma dentro da página da SNJ para avaliação e } \\
\text { informes dos resultados das conferências. Para discussão dos avanços com } \\
\text { atualização constante, conexão com os gestores estaduais e municipais. }\end{array}$ & \\
\hline $8^{\circ}$ & $\begin{array}{l}1071 \text { - Criação de campanhas publicitarias e educacionais que eduque a } \\
\text { sociedade a lidar com os jovens com deficiência, respeitando seus desejos, } \\
\text { autonomia e necessidade de experimentações, esclarecendo que o jovem } \\
\text { deficiente e seu acompanhante são pessoas distintas e que o acompanhante } \\
\text { só seja solicitado quando necessária. }\end{array}$ & \\
\hline $9^{\circ}$ & $\begin{array}{l}246 \text {-Estimular o tema "Comunicação Social" no ambiente escolar, } \\
\text { incentivando a comunicação social/educomunicação como tema transversal, } \\
\text { com projetos, aprimorando a infraestrutura de comunicação na escola. }\end{array}$ & \\
\hline
\end{tabular}




\section{RESULTADO: DIVERSIDADE}

\begin{tabular}{|c|c|c|}
\hline $\mathbf{N}^{\circ}$ & PROPOSTAS & PONTOS \\
\hline $1^{\circ}$ & $\begin{array}{l}113 \text { - Garantir e implementar na grade curricular a temática de direitos humanos e } \\
\text { da diversidade (orientação sexual, identidade de gênero, étnico/racial, gênero, } \\
\text { étnico-cultural, combate a intolerância religiosa, entre outras) de acordo com o } \\
\text { que é previsto no ECA. Com formação continuada de professores/as, e criação de } \\
\text { material pedagógico/didático especifica (Ex: Projeto Escola Sem Homofobia) e o } \\
\text { desenvolvimento de ações com a comunidade escolar (família, professores e } \\
\text { estudantes). }\end{array}$ & \\
\hline $2^{\circ}$ & $\begin{array}{l}124 \text { - Garantir o cumprimento efetivo dos direitos iguais no mundo do trabalho } \\
\text { (acesso, salários, carga horaria, formação) com especial atenção para população } \\
\text { jovem dos seguintes segmentos: mulheres, deficientes, negros, LGBT, indígenas, } \\
\text { ciganos, ribeirinhos, quilombolas, do campo, povos das aguas e egressos de } \\
\text { medidas socioeducativas. }\end{array}$ & \\
\hline $3^{\circ}$ & $\begin{array}{l}1037 \text { - Garantir e implementar na grade curricular a temática de direitos humanos } \\
\text { e da diversidade (orientação sexual, identidade de gênero, étnico racial, combate } \\
\text { a intolerância religiosa, de acordo com o que é previsto no eca, formação } \\
\text { continuada de professores, e a criação de matérias pedagógicos específicos e o } \\
\text { desenvolvimento de ações com a comunidade escolar, respeitando todos(as), } \\
\text { estudantes tráns, da rede de ensino possam utilizar os banheiros de acordo com } \\
\text { seus gêneros, assim como tem seus nomes sociais respeitados em todas as } \\
\text { esferas educacionais. }\end{array}$ & \\
\hline $4^{0}$ & $\begin{array}{l}393 \text { - Criação de cotas de no mínimo } 30 \% \text { destinadas a juventude de povos e } \\
\text { comunidades tradicionais nos concursos públicos (municipal, estadual e federal) e } \\
\text { estimular a contratação de PCTs nos cargos de confiança dos governos, sem } \\
\text { perder nenhum direito já adquirido. }\end{array}$ & \\
\hline $5^{\circ}$ & $\begin{array}{l}150 \text { - Implementar, fomentar e garantir a capacitação e formação de profissionais } \\
\text { de educação, da saúde, assistência social, segurança publica e profissionais do } \\
\text { Direito, sobre diversidade religiosa, sexual, étnica, identidades de gênero } \\
\text { garantindo o enfrentamento ao racismo, LGBTfobia e todas as formas de violência } \\
\text { e discriminação promovidas pelo Estado (discriminação institucional). }\end{array}$ & \\
\hline $6^{\circ}$ & $\begin{array}{l}153 \text { - Aprovar lei que define os crimes de ódio e de intolerância e as formas de } \\
\text { coibi-los, nos parâmetros de outras leis tal como a de crime de racismo, para } \\
\text { proteger todas as pessoas, inclusive jovens, independentes de classe e origem } \\
\text { social, condição de migrante, refugiado ou deslocado interno, orientação sexual, } \\
\text { identidade e expressão de gênero, idade, religiâo, situação de rua e deficiência. }\end{array}$ & \\
\hline $7^{\circ}$ & $\begin{array}{l}147 \text { - Criação de uma lei de incentivo à contratação de mulheres e homens trans } \\
\text { e travestis por empresas públicas e privadas, que as mesmasrecebam } \\
\text { emcontrapartida incentivos fiscais. Realização de campanhas de incentivo à } \\
\text { inserção no mercado de trabalho desse público; Estender os registros de } \\
\text { ocorrência (RDO) para todos os Estados do Brasil, seguindo como modelo o } \\
\text { Estado de São Paulo, a fim de mapear os crimes de ódio e delito de intolerância } \\
\text { em razão de orientação sexual e identidade de gênero no âmbito nacional, pela } \\
\text { criminalização da LGBTfobia. }\end{array}$ & \\
\hline $8^{\circ}$ & $\begin{array}{l}114 \text {-Inclusão dos idiomas LIBRAS e braille como componente curricular } \\
\text { obrigatório, do ensino fundamental, médio e superior, com formação continuada e } \\
\text { disponibilização de recursos didáticos imprescindíveis para a realização } \\
\text { qualificada dos trabalhos. }\end{array}$ & \\
\hline $9^{\circ}$ & $\begin{array}{l}123 \text { - Garantir todas as condições para a funcionalidade e exercício do controle e } \\
\text { fiscalização, por parte dos conselhos de políticas públicas de igualdade racial e } \\
\text { igualdade de gênero para o cumprimento das leis (Lei } n^{\circ} 11.645 / 2008 \text { ) População } \\
\text { indígena (Lei } n^{\circ} 11.340 / 06 \text { - Maria da Penha) ( } \mathrm{N}^{\circ} 13.104 / 15 \text {-feminicídio) (10. } \\
639 / 03 \text { - estudo afro nas escolas) e a lei que garante o nome social pelas } \\
\text { travestis e transexuais e do Estatuto da Pessoa com Deficiência. }\end{array}$ & \\
\hline
\end{tabular}




\section{RESULTADO: TERRITÓRIO}

\begin{tabular}{|c|c|c|}
\hline $\mathbf{N}^{\circ}$ & PROPOSTAS & PONTOS \\
\hline $1^{0}$ & $\begin{array}{l}312 \text { - Ampliar e acelerar o processo de Reforma Agrária e regularização } \\
\text { fundiária, bem como reconhecimento e demarcação de terras pertencentes a } \\
\text { povos e comunidades tradicionais, em especial das terras indígenas e } \\
\text { quilombolas, acabando com as práticas forçadas de remoção de seus } \\
\text { territórios. Assim, viabilizando a regularização da documentação de } \\
\text { assentamentos já existentes, permitindo que os jovens tenham condições de } \\
\text { permanecer ou regressar as suas terras originais, e serem assim } \\
\text { contemplados pelos programas, projetos e ações para a juventude rural. }\end{array}$ & \\
\hline $2^{\circ}$ & $\begin{array}{l}313 \text { - Elaborar Plano Nacional de Sucessão Rural para a Juventude do } \\
\text { Campo, Comunidades Tradicionais e Indígenas, que combine/articule políticas } \\
\text { nacionais, que respeitem as especificidades regionais dos territórios, que } \\
\text { tenham como eixos estruturantes: a) terra e água; b) assistência técnica; c) } \\
\text { crédito; e) educação DO/NO/PARA o campo; e) cultura, esporte e lazer e f) } \\
\text { desburocratização e aprimoramento dos programas existentes (Bolsa Jovem } \\
\text { Rural, Nossa Primeira Terra, Programa Nacional de Crédito Fundiário) }\end{array}$ & \\
\hline $3^{\circ}$ & $\begin{array}{l}288 \text { - Criar um plano nacional de desapropriação de áreas que não cumprem a } \\
\text { função social, com um fundo monetário gerido por um conselho de gestão da } \\
\text { terra urbana composto por representantes do governo }(1 / 3) \text { e representantes } \\
\text { dos movimentos de moradia }(2 / 3) \text {, com obrigatoriedade dos municípios e } \\
\text { estados contribuírem monetariamente para as desapropriaçães em seus } \\
\text { territórios, afim de propiciar a regularização e promoção de uma reforma } \\
\text { urbana que corrobore com o direito a cidade. Pela reforma urbana, Já! }\end{array}$ & \\
\hline $4^{0}$ & $\begin{array}{l}307 \text {-Implementar políticas de mobilidade que garantam melhoria das diversas } \\
\text { modalidades de transporte, que garantam a gratuidade para os estudantes no } \\
\text { sistema de transporte público municipal e estadual para o acesso à cultura, } \\
\text { lazer e educação na perspectiva das cidades educadoras; que garantam uso } \\
\text { de bicicletas como meio de transporte modelo para uma cidade saudável e } \\
\text { sustentável pensando a malha cicloviária interligada a outros modais que } \\
\text { funcionem 24horas e bicicletários espalhados em diversos locais; que } \\
\text { garantam transporte público de maneira adequada no período noturno e aos } \\
\text { finais de semana e que garantam transporte público de qualidade conforme as } \\
\text { demandas e especificidades do meio rural. }\end{array}$ & \\
\hline $5^{0}$ & $\begin{array}{l}289 \text { - Garantir a implementação do passe livre estudantil em todos os } \\
\text { municípios }\end{array}$ & $\angle 4$ \\
\hline $6^{\circ}$ & $\begin{array}{l}1055 \text { - Garantir os direitos de mobilidade nos termos da proposta } 307 \text {, } \\
\text { ampliando os referidos direitos de estudantes para jovens de } 15 \text { a } 29 \text { anos, } \\
\text { com prioridade aos de baixa renda. }\end{array}$ & \\
\hline $7^{\circ}$ & $\begin{array}{l}300 \text { - Garantir a implementação do passe livre estudantil municipal e } \\
\text { intermunicipal, irrestrito e ilimitado para os jovens da cidade, do campo, da } \\
\text { floresta e das águas. }\end{array}$ & \\
\hline $8^{\circ}$ & $\begin{array}{l}1056 \text { - Criar e implementar o Fundo Nacional e Inter federativo de mobilidade } \\
\text { para todos os jovens, para subsidiar a tarifa zero, garantindo um transporte } \\
\text { publico, gratuito, de qualidade, e acessibilidade em toda a frota, fazendo se } \\
\text { cumprir o artigo 31, paragrafo único do estatuto da juventude. }\end{array}$ & \\
\hline $9^{\circ}$ & $\begin{array}{l}294 \text { - Garantir a implantação dos aspectos de acessibilidade em todas as vias } \\
\text { públicas. }\end{array}$ & 8 \\
\hline
\end{tabular}




\section{RESULTADO: MEIO AMBIENTE}

\begin{tabular}{|c|c|c|}
\hline $\mathbf{N}^{0}$ & PROPOSTAS & PONTOS \\
\hline $1^{0}$ & $\begin{array}{l}332 \text { - Promover a educação ambiental na educação formal pública e } \\
\text { diferenciada, como as Escolas para Povos e Populações Tradicionais, com o } \\
\text { fortalecimento das Escolas Sustentáveis e na promoção dos programas } \\
\text { educacionais em especial a Comissão de Meio Ambiente e Qualidade de Vida- } \\
\text { COM-VIDA. Fortalecer Escolas Familiares Agrícolas, como práticas ambientais } \\
\text { agroecológicas e sustentáveis. Pensando alternativas associativas para as } \\
\text { escolas família agrícola na manutenção e ampliação da 'mobilização' de } \\
\text { recursos. }\end{array}$ & \\
\hline $2^{0}$ & $\begin{array}{l}1015 \text { - Combater o uso e abuso dos agrotóxicos, fortalecendo a } \\
\text { sustentabilidade através da agroecologia, por meio de programas sociais para } \\
\text { a agricultura familiar e a Juventude Rural, com ênfase na compensação } \\
\text { econômica em contrapartida à preservação ambiental, assistência técnica, } \\
\text { acesso ao crédito e reforma Agraria. }\end{array}$ & \\
\hline $3^{0}$ & $\begin{array}{l}1016 \text { - Criação de legislação que proteja, reconheça e ampare o Bioma } \\
\text { Cerrado, frisando o monitoramento via satélite do desmatamento e das } \\
\text { queimadas. }\end{array}$ & \\
\hline $4^{0}$ & $\begin{array}{l}1019 \text { - Garantir consultar previas com poder deliberativo às comunidades } \\
\text { tradicionais, povos indígenas e comunidade em geral, para a implantação de } \\
\text { empreendimentos, públicos ou privados, de grande risco ou impacto ambiental } \\
\text { ou qualquer outros que possam afetar o meio ambiente onde esses povos e } \\
\text { comunidades habitem. }\end{array}$ & \\
\hline $5^{\circ}$ & $\begin{array}{l}320 \text { - Ampliar os programas de incentivo técnico e financeiro para a juventude } \\
\text { do campo que desenvolve práticas sustentáveis, para a agricultura familiar e } \\
\text { proprietários de terrenos situados em áreas de proteção ambiental e } \\
\text { permanente (APAAPP), formando redes de ecoturismo, bem como apoiar a } \\
\text { divulgação dessas iniciativas nos meios de comunicação. }\end{array}$ & \\
\hline $6^{0}$ & $\begin{array}{l}319 \text { - Priorizar os produtos orgânicos nas aquisições de alimentos pelos } \\
\text { órgãos governamentais; bem como fomentar práticas agroecológicas, a partir } \\
\text { da organização de jovens com implementação de hortas comunitárias, quintais } \\
\text { produtivos, em escolas, terrenos baldios e públicos, quintais, praças rurais e } \\
\text { urbanas; inclusive em centros de ressocialização, instalação de tecnologias } \\
\text { alternativas, como exemplo: cisternas de placas, biodigestor, filtros biológicos, } \\
\text { canteiros econômicos, preferencialmente nas comunidades carentes. }\end{array}$ & \\
\hline $7^{\circ}$ & $\begin{array}{l}1020 \text { - Realizar uma ampla consulta, de forma deliberativa, a sociedade civil, } \\
\text { os movimentos sociais (formais ou não) sobre o código de mineração, em todo } \\
\text { país. }\end{array}$ & \\
\hline $8^{\circ}$ & $\begin{array}{l}324 \text { - Incentivo a permanência do jovem no campo, implantação de um } \\
\text { sistema de economia solidária com empreendimentos sustentáveis para } \\
\text { juventude. Efetivação e fortalecimento das políticas publica já existente } \\
\text { (PNAE, Pronaf e etc.) e incentivar novas, ampliando as linhas de credito para } \\
\text { plantio de alimentos orgânicos. }\end{array}$ & \\
\hline $9^{\circ}$ & $\begin{array}{l}327 \text { - Incluir Educação Ambiental e práticas de economia solidária como } \\
\text { disciplinas na grade curricular, desde o jardim ao ensino universitário, com a } \\
\text { coordenação do Ministério do Meio Ambiente e do Ministério da Educação, } \\
\text { capacitando os educadores para exercer as atividades e projetos com o órgão } \\
\text { de Meio Ambiente local. Essas propostas poderão fazer parte de um Programa } \\
\text { sobreJuventude e Meio Ambiente e do Plano Nacional de Juventude e Meio } \\
\text { Ambiente do Governo Federal, que trate da destinação do material de coleta } \\
\text { seletiva da escola às cooperativas, o lixo orgânico à compostagem e o rejeito } \\
\text { para o aterro, zerando assim, o impacto dos resíduos para os aterros } \\
\text { sanitários e para o meio ambiente. }\end{array}$ & \\
\hline
\end{tabular}




\section{RESULTADO: SEGURANÇA}

\begin{tabular}{|c|c|c|}
\hline $\mathbf{N}^{0}$ & PROPOSTAS & PONTOS \\
\hline $1^{0}$ & $\begin{array}{l}360 \text { - Não à redução da maioridade penal, pelo cumprimento efetivo das medidas } \\
\text { previstas no Estatuto da Criança e do Adolescente. }\end{array}$ & 103 \\
\hline $2^{\circ}$ & 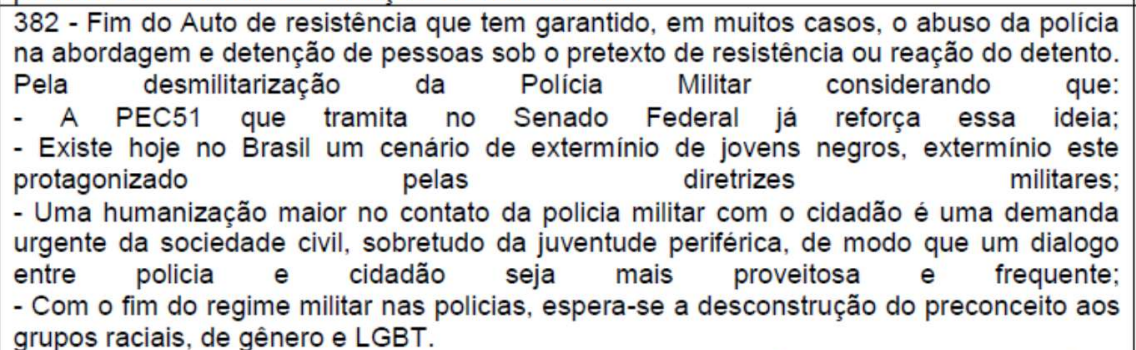 & 83 \\
\hline $3^{0}$ & $\begin{array}{l}367 \text {-Revisão da política de Drogas com a implementação da descriminalização e } \\
\text { regulamentação de todas as drogas. }\end{array}$ & \\
\hline $4^{0}$ & $\begin{array}{l}394 \text { - Criar um Plano Nacional de Enfrentamento aos Homicídios que combata o } \\
\text { exterminio da Juventude Negra, dos Jovens de Povos e Comunidades Tradicionais, que } \\
\text { vise a desmilitarização e a federalização das policias, fim dos autos de resistência, acesso } \\
\text { à justiça, e formação especifica em Direitos Humanos e Cidadanias voltados ao } \\
\text { atendimento aos Povos e Comunidades Tradicionais, que visem eliminar ações } \\
\text { repressoras por mecanismos de abordagem humanizados que respeitem as } \\
\text { especificidades de identidade de gênero, raça/etnia, tradições e orientação sexual. } \\
\text { Fortalecer e fomentar e ampliar o "Plano Juventude Viva" com um recorte especifico para: } \\
\text { Jovens negros, jovens PCTs, jovens LGBTs, respeitando os recortes de gênero e } \\
\text { garantindo a participação direta e indireta do plano destas juventudes como forma de } \\
\text { estimular a valorização destas identidades combatendo preconceitos e opressões. }\end{array}$ & \\
\hline $5^{\circ}$ & $\begin{array}{l}378 \text { - Garantir no cumprimento de medidas socioeducativas e no sistema prisional } \\
\text { melhoria das atividades de ressocialização por meio de ações educacionais com cursos } \\
\text { técnicos e palestras para a população carcerária, programas de inclusão dos jovens } \\
\text { egressos de medidas socioeducativas e do sistema penitenciário no mercado de trabalho, } \\
\text { para que cumpra sua função socioeducativa e de reinserção social. }\end{array}$ & \\
\hline $6^{\circ}$ & $\begin{array}{l}368 \text {-Descriminalização e regulamentação do acesso e uso de drogas e controle de sua } \\
\text { produção e da entrada pelas fronteiras do país. }\end{array}$ & \\
\hline $7^{0}$ & $\begin{array}{l}386 \text {-Implementar o programa valoriza vida. Baseado nas diretrizes do plano juventude } \\
\text { viva, com a criação de mecanismos que fomentem programas (sobretudo no âmbito } \\
\text { municipal) voltada para a prevenção de homicídios, principalmente da juventude negra, de } \\
\text { periferia, atuando com jovens de } 16 \text { à } 25 \text { anos incompletos, cadastrados no cadastro } \\
\text { único, e matriculados na rede pública de ensino federal, estadual ou municipal. Onde } \\
\text { esses possam atuar no contraturno escolar com atividades de empoderamento social, } \\
\text { capacitação esportiva e cultural, com o objetivo de levarem esses aprendizados de volta } \\
\text { para as suas comunidades se tornando agentes multiplicadores, além de garantir acesso } \\
\text { a atividades diversas de lazer, com o intuito de desconstruir a cultura de violência. Esses } \\
\text { jovens seriam ainda capacitados pelo órgão de educação do municipio para atuarem junto } \\
\text { às escolas municipais auxiliando em problemas como o de evasão e de defasagem } \\
\text { escolar. }\end{array}$ & 15 \\
\hline $8^{\circ}$ & $\begin{array}{l}1000 \text {-Garantir o fim do auto de resistência que, em muitos casos, tem favorecido o abuso } \\
\text { da policia na abordagem e detenção de pessoas sob o pretexto de resistência ou reação } \\
\text { do detento. Pela desmilitarização da policia militar efetivando uma formação em direitos } \\
\text { humanos para agentes de seguranças do estado, com a ampliação a carga horária da } \\
\text { area de conhecimento em direitos humanos e das relações sociais no processo de } \\
\text { formação de profissionais de segurança publica, possibilitando vivencias com o sistema } \\
\text { penitenciário e serviços de referencia as pessoas em vulnerabilidade social, realizando } \\
\text { treinamento em programas de mecanismos de abordagem que respeitem as } \\
\text { especificidades de gênero, etnia e orientação sexual. }\end{array}$ & \\
\hline $9^{\circ}$ & $\begin{array}{l}372 \text {-Garantia de segurança efetiva com foco na área jurídica de defensorias, promotorias } \\
\text { públicas e AGU's nos territórios, com extensão de núcleos em todos os municipios, } \\
\text { garantindo acessibilidade à justiça e implementação no âmbito estadual e municipal de } \\
\text { Conselhos de Segurança Comunitária e pacificadores, com a participação de jovens nas } \\
\text { formações, capacitações e qualificação dos agentes de segurança pública, garantindo os } \\
\text { principios pautados na Declaração dos Direitos Humanos, CF, entre outros. }\end{array}$ & \\
\hline
\end{tabular}

BRASIL. Secretaria Nacional de Juventude. $3^{\text {a }}$ Conferência Nacional de Juventude. Disponível em: <http://juventude.gov.br/conferencia/>. Acesso em: 07 jul.2015. 


\section{ANEXO M - RESOLUÇÕES APROVADAS NA $1^{\text {a }}$ CONFERÊNCIA MUNICIPAL DE JUVENTUDE}

\begin{tabular}{|c|c|}
\hline \multicolumn{2}{|c|}{ GT - Sexualidade, Diversidade e Preconceito. } \\
\hline Desafio & Solução \\
\hline $\begin{array}{l}\text { 1. Melhor atenção à saúde sexual e } \\
\text { reprodutiva, de adolescentes e jovens, } \\
\text { garantindo seus direitos e oferecendo } \\
\text { serviços de orientação, prevenção e } \\
\text { atendimento, independente da orientação } \\
\text { sexual. }\end{array}$ & $\begin{array}{l}\text { 1. Criação de um centro de referência em } \\
\text { saúde sexual e reprodutiva para adolescentes } \\
\text { e jovem. } \\
\text { 2. Capacitar profissionais (médicos, } \\
\text { enfermeiros e recepcionistas) para o } \\
\text { atendimento específico de adolescentes e } \\
\text { jovem. }\end{array}$ \\
\hline \multirow{2}{*}{$\begin{array}{l}\text { 2. Garantir e ampliar que adolescentes e } \\
\text { jovens tenham acesso a informações corretas } \\
\text { e atualizadas em relação às temáticas ligadas } \\
\text { a sua sexualidade. }\end{array}$} & $\begin{array}{l}\text { 1. Ampliar para todas as escolas do município } \\
\text { o programa Núcleo IRSSA, fortalecendo a } \\
\text { parceria saúde - educação. }\end{array}$ \\
\hline & $\begin{array}{l}\text { 2. Capacitar profissionais da saúde, educação } \\
\text { e adolescentes e jovens, para serem } \\
\text { multiplicadores/as de ações educativas e de } \\
\text { informação para outros adolescentes e } \\
\text { jovens. }\end{array}$ \\
\hline \multicolumn{2}{|c|}{ GT - DROGAS } \\
\hline \multirow{3}{*}{$\begin{array}{l}\text { 1. Ampliar ações de fiscalização, combate e } \\
\text { prevenção ao uso indevido de drogas. }\end{array}$} & $\begin{array}{l}\text { 1. Reformulação e modernização das leis que } \\
\text { regem o tráfico de drogas e vendas lícitas } \\
\text { para menores de } 18 \text { anos com ou sem receita } \\
\text { médica; }\end{array}$ \\
\hline & $\begin{array}{l}\text { 2. Desenvolvimento de ações sócio- } \\
\text { educativas que incluam o jovem como } \\
\text { protagonista das ações de prevenção ao uso } \\
\text { de drogas; }\end{array}$ \\
\hline & $\begin{array}{l}\text { 3. Aumentar o número de campanhas } \\
\text { educativas, visando proporcionar as famílias } \\
\text { e aos jovens uma maior conscientização } \\
\text { sobre as drogas; }\end{array}$ \\
\hline \multicolumn{2}{|c|}{ GT - Família } \\
\hline \multirow[t]{2}{*}{$\begin{array}{l}\text { 1. Ampliar e/ou criar ações que promovam } \\
\text { uma maior articulação da família com os } \\
\text { jovens. }\end{array}$} & $\begin{array}{l}\text { 1. Estimular com os diferentes grupos de } \\
\text { jovens existentes, a criação de ações de } \\
\text { integração com a família, buscando criar um } \\
\text { intercâmbio de idéias, troca de experiências } \\
\text { entre outros pontos comuns que possam } \\
\text { existir. }\end{array}$ \\
\hline & $\begin{array}{l}\text { 2. Criação de encontros e espaços de troca } \\
\text { de experiência e convivência dentro do } \\
\text { município. }\end{array}$ \\
\hline \multirow{2}{*}{$\begin{array}{l}\text { 2. Melhorar a atenção, prevenção e outros } \\
\text { aspectos ligados à família, visando uma } \\
\text { melhor qualidade de vida. }\end{array}$} & $\begin{array}{l}\text { 1. Ampliar os serviços e espaços de atenção } \\
\text { à família dentro do município, incluindo } \\
\text { serviços específicos para os/a jovens. }\end{array}$ \\
\hline & $\begin{array}{l}\text { 2. Criação de Programas direcionados aos } \\
\text { jovens, mas que busquem também a } \\
\text { participação, envolvimento da família nas } \\
\text { ações desenvolvidas. }\end{array}$ \\
\hline \multicolumn{2}{|c|}{ GT - Cidade e Meio Ambiente } \\
\hline \multirow{2}{*}{$\begin{array}{l}\text { 1. Falta de informação de boa parte da } \\
\text { população em relação às questões e } \\
\text { cuidados ambientais. }\end{array}$} & $\begin{array}{l}\text { 1. Criação e/ou ampliação de programas e } \\
\text { ações dentro do município que possam levar } \\
\text { informações sobre o meio ambiente. }\end{array}$ \\
\hline & $\begin{array}{l}\text { 2. Capacitação de profissionais, instituições e } \\
\text { principalmente adolescentes e jovens para } \\
\text { atuarem como multiplicadores/as de ações de } \\
\text { informação e educacaão ambiental. }\end{array}$ \\
\hline
\end{tabular}


2. Ampliação e melhoramento dos espaços físicos do aterro sanitário municipal, bem como implementação da coleta de resíduos urbanos.

1. Garantir a qualificação profissional dos jovens e sua preparação e exigências do mercado de trabalho.

2. Garantir que os Programas, cursos e ações que visem à profissionalização e encaminhamento ao mercado de trabalho possam chegar até o jovem.

\section{GT - Cultura, Esporte e Tempo Livre.}

1. Garantir que o esporte seja um instrumento de educação e inclusão social.

2. Garantir o acesso e a divulgação dos eventos de qualquer natureza que tenham a participação do jovem prevista.

3. Ampliação os espaços de representação da juventude
1. Inclusão da disciplina de educação física nas escolas municipais.

2. Criação de mais centros de referências de

1. Realização de obras para aumentar o tempo de vida e utilização do aterro municipal. 2. Criação de cooperativas, através de parceria entre empresas e a prefeitura, bem como cadastramento dos catadores de lixo do município.

3. Implementação da coleta seletiva dentro do município, e ampliação de lixeiras ecológicas (material reciclado) pelo município.

1. Aumentar o número de escolas técnicas, com cursos voltados para o mercado profissional local e regional;

2. Criar um centro educacional de línguas estrangeiras onde os jovens sejam preparados para o mercado de trabalho nacional e internacional;

3. Criar e/ou ampliar os espaços que oferecem cursos profissionalizantes dentro do município, bem como a criação de um centro de juventude que possa integrar ações do poder público + poder privado + sociedade civil.

1. Criar uma rede de comunicação entre os programas, instituições profissionalizantes e a mídia para que os cursos e ações possam ser melhores divulgados, e cheguem até o conhecimento da juventude.

2. Mapeamento das políticas públicas existentes, de incentivo ao trabalho e profissionalização dos jovens, juntamente com os programas e instituições que oferecem esse trabalho dentro do município juventude por todo o país, que possam oferecer atividades esportivas de educação e inclusão social.

3. Estabelecer parcerias com o Estado e com a União para realização de projetos de esporte social.

1. Criação de um web-site "Jovem". Para concentração e divulgação de eventos e outras ações, projetos e assuntos relacionados à juventude.

2. Melhorar o sistema público de transporte, de forma a facilitar a participação do jovem em eventos, bem como maior divulgação e acesso dos horários e itinerários.

3. Criação de uma rede ou canal direto de comunicação entre os principais organizadores de eventos e ações para a juventude, com as lideranças comunitárias e grupos juvenis, visando 0 acesso à informação.

1. Criação da Coordenadoria de Juventude e do Conselho Municipal de Juventude. 


\begin{tabular}{|c|c|}
\hline & $\begin{array}{l}\text { 2. Criação dos centros de referência de } \\
\text { juventude. }\end{array}$ \\
\hline & $\begin{array}{l}\text { 3. Ampliação do Programa Escola da Família } \\
\text { dentro do município. }\end{array}$ \\
\hline \multicolumn{2}{|c|}{ GT - Educação } \\
\hline \multirow{2}{*}{$\begin{array}{l}\text { 1. Buscar uma participação mais ampla e } \\
\text { efetiva do educando e da família dentro do } \\
\text { ambiente e questões escolares. }\end{array}$} & $\begin{array}{l}\text { 1. Garantir e criar espaços (cursos, festas, } \\
\text { palestras, ações na comunidade, entre } \\
\text { outras) para incentivar os educandos, as } \\
\text { famílias e os educadores a participarem da } \\
\text { vida escolar integrando-a a vida comunitária; }\end{array}$ \\
\hline & $\begin{array}{l}\text { 2. Estruturar melhor o Programa Escola da } \\
\text { Família e outros projetos desenvolvidos no } \\
\text { ambiente escolar. }\end{array}$ \\
\hline \multirow{3}{*}{$\begin{array}{l}\text { 2. Garantir uma ação docente mais efetiva, } \\
\text { conceitual e com melhores resultados. }\end{array}$} & $\begin{array}{l}\text { 1. Exigir e garantir a formação continuada } \\
\text { com a devida avaliação dos trabalhos e } \\
\text { docentes, de acordo às condições e } \\
\text { necessidades locais; }\end{array}$ \\
\hline & $\begin{array}{l}\text { 2. Melhorar a remuneração docente, a } \\
\text { redução da quantidade de educandos por } \\
\text { sala e incentivar a realização de pesquisas } \\
\text { para aprimorar as metodologias de ensino, } \\
\text { visando melhorar o processo de ensino- } \\
\text { aprendizagem; }\end{array}$ \\
\hline & $\begin{array}{l}\text { 3. Desenvolver e implementar novas } \\
\text { metodologias de ensino-aprendizagem, bem } \\
\text { como a ampliação de atividades sócio- } \\
\text { culturais e educativas de acordo com a } \\
\text { realidade dos educandos. }\end{array}$ \\
\hline
\end{tabular}

SANTA BÁRBARA D'OESTE. Comissão Organizadora da $1^{\text {a }}$ Conferência Municipal de Juventude. Relatório final da $1^{\text {a }}$ Conferência Municipal de Juventude de Santa Bárbara d'Oeste-SP. Santa Bárbara d'Oeste: [s.n.], 2008. 


\section{ANEXO N - RESOLUÇÕES APROVADAS NA $2^{\text {a }}$ CONFERÊNCIA MUNICIPAL DE JUVENTUDE}

\begin{tabular}{|c|c|}
\hline Temas (prioridades) & Demandas \\
\hline \multirow{6}{*}{$\begin{array}{l}\text { Juventude: educação e trabalho } \\
\qquad\left(2^{a}\right)\end{array}$} & $\begin{array}{l}\text { 1. Criação uma universidade estadual ou } \\
\text { federal no município; }\end{array}$ \\
\hline & $\begin{array}{l}\text { 2. Elaborar atividades visando } \\
\text { compartilhamento das responsabilidades do } \\
\text { processo educativo, entre escola e família; }\end{array}$ \\
\hline & $\begin{array}{l}\text { 3. Leis que contemplem uma nova disciplina de } \\
\text { orientação vocacional no último ano escolar; }\end{array}$ \\
\hline & $\begin{array}{l}\text { 4. Implementar e aumentar o número de aulas } \\
\text { nas grades curriculares de matérias que } \\
\text { trabalhe de forma multidisciplinar os } \\
\text { conhecimentos gerais e atualidades, } \\
\text { estimulando o pensamento crítico em sala de } \\
\text { aula; }\end{array}$ \\
\hline & $\begin{array}{l}\text { 5. Através de lei, fazer que o estágio incluído } \\
\text { dentro da carga horária obrigatória, seja aceito } \\
\text { como experiência profissional; }\end{array}$ \\
\hline & $\begin{array}{l}\text { 6. Implementação e ampliação de cursos } \\
\text { técnico-profissionalizantes obrigatórios nos } \\
\text { contra-turno como forma de minimizar a } \\
\text { evasão escolar; }\end{array}$ \\
\hline \multirow{8}{*}{$\begin{array}{l}\text { Juventude: comunicação e cultura } \\
\qquad\left(6^{\mathrm{a}}, 7^{\mathrm{a}}, 8^{\mathrm{a}}\right)\end{array}$} & $\begin{array}{l}\text { 1. Criar um site informativo com a cara da } \\
\text { juventude, visando ser um novo atrativo para } \\
\text { os jovens da cidade. Integrar esse site a redes } \\
\text { sociais para divulgação inclusive das ações do } \\
\text { Conselho Municipal de Juventude; }\end{array}$ \\
\hline & $\begin{array}{l}\text { 2. Fazer o Informativo Mensal de Cultura } \\
\text { chegar às escolas municipais e estaduais para } \\
\text { ampliar a divulgação da programação cultura } \\
\text { do Município; }\end{array}$ \\
\hline & $\begin{array}{l}\text { 3. Criar oficinas regionais para o jovem da } \\
\text { comunidade, não limitando as vagas para que } \\
\text { o maior número obtenha acesso; }\end{array}$ \\
\hline & $\begin{array}{l}\text { 4. Implantar o projeto "Leitura em Movimento", } \\
\text { estimulando o hábito da leitura entre os jovens; }\end{array}$ \\
\hline & $\begin{array}{l}\text { 5. Criar espaços públicos como praças da } \\
\text { juventude e quadras poliesportivas que } \\
\text { possibilitem o convívio, a diversidade cultural e } \\
\text { a segurança dos jovens. Estes espaços } \\
\text { poderão ser utilizados para integrar jovens e } \\
\text { adolescentes visando ocupar o tempo livre em } \\
\text { atividades que possam gerar crescimento } \\
\text { pessoal e profissional, disciplina, valores, ética } \\
\text { e cidadania; }\end{array}$ \\
\hline & $\begin{array}{l}\text { 6. Utilizar e criar espaços públicos para } \\
\text { incentivar e facilitar a prática de dança, música, } \\
\text { teatro, circo e outras atividades culturais; }\end{array}$ \\
\hline & $\begin{array}{l}\text { 7. Permitir que os jovens menores retirem } \\
\text { livros nas bibliotecas municipais; }\end{array}$ \\
\hline & $\begin{array}{l}\text { 8. Identificar os pontos turísticos, as áreas de } \\
\text { lazer e de cultura no município e no estado, }\end{array}$ \\
\hline
\end{tabular}




\begin{tabular}{|c|c|}
\hline & $\begin{array}{l}\text { além de melhorar suas condições de acesso, } \\
\text { atendimento e divulgação a população; }\end{array}$ \\
\hline & $\begin{array}{l}\text { 9. Maior aquisição de volume de livros do } \\
\text { mesmo título especialmente sucessos de } \\
\text { vendas como incentivo à leitura. }\end{array}$ \\
\hline \multirow{4}{*}{$\begin{array}{c}\text { Juventude: cidade, campo e transporte } \\
\text { público } \\
\left(1^{\mathrm{a}}, 13^{\mathrm{a}} \text { e } 14^{\mathrm{a}}\right)\end{array}$} & $\begin{array}{l}\text { 1. Melhorar o transporte público municipal, } \\
\text { aumentando a disponibilidade de integração } \\
\text { de linhas pelo município, ampliando também } \\
\text { os horários e bairros atendidos inclusive aos } \\
\text { fins de semana. Melhorar condições de uso e } \\
\text { conforto dos veículos utilizados; }\end{array}$ \\
\hline & $\begin{array}{l}\text { 2. Realizar cursos de capacitação permanente } \\
\text { para todos(as) motoristas para melhor } \\
\text { atendimento a população; }\end{array}$ \\
\hline & $\begin{array}{l}\text { 3. Implantação de cursos tecnológicos de } \\
\text { agropecuária voltados à juventude; }\end{array}$ \\
\hline & $\begin{array}{l}\text { 4. Criar políticas para reconhecer a agricultura } \\
\text { urbana e pere-urbana como agricultura familiar } \\
\text { e sua inserção nos programas de incentivo } \\
\text { pertinentes. }\end{array}$ \\
\hline \multirow{5}{*}{$\begin{array}{l}\text { Juventude e meio ambiente } \\
\qquad\left(15^{\mathrm{a}}\right)\end{array}$} & $\begin{array}{l}\text { 1. Incentivar a Coleta Seletiva e o Consumo } \\
\text { racional; }\end{array}$ \\
\hline & $\begin{array}{l}\text { 2. Implantar à Política Nacional de Resíduos } \\
\text { Sólidos; }\end{array}$ \\
\hline & $\begin{array}{l}\text { 3. Incentivar a criação de cooperativas de } \\
\text { catadores; }\end{array}$ \\
\hline & $\begin{array}{l}\text { 4. Garantir espaços para juventude no } \\
\text { Conselho Municipal de Defesa do Meio } \\
\text { Ambiente; } \\
\text { 5. Incentivar e implementar a rede da } \\
\text { juventude pelo meio ambiente; }\end{array}$ \\
\hline & $\begin{array}{l}\text { 6. Incentivar Ações de Educação ambiental } \\
\text { entre jovens e adolescentes. }\end{array}$ \\
\hline \multirow[t]{2}{*}{ Juventude e povos tradicionais } & $\begin{array}{l}\text { 1. Capacitar educadores (as) em consonância } \\
\text { com a Lei n. }{ }^{\circ} \text { 9394/96 (Lei de Diretrizes de } \\
\text { Base da Educação - LDB), Lei n. }{ }^{\circ} \text { (a) L } \\
\text { 8069/90(Estatuto da Criança e do Adolescente } \\
\text { - ECA) e a Lei n. }{ }^{\circ} 10639 / 03 \text { que institui o ensino } \\
\text { afro nas escolas; }\end{array}$ \\
\hline & $\begin{array}{l}\text { 2. Formação e preparo as instituições de } \\
\text { aparato repressivo (polícia militar, civil, guarda } \\
\text { municipal e outras) instruindo quanto à lei } n .{ }^{\circ} \\
10639 / 03 \text { e a lei } 8069 / 90 \text { quanto a abordagem } \\
\text { aos jovens em especial a juventude negra. }\end{array}$ \\
\hline \multirow{2}{*}{$\begin{array}{l}\text { Juventude: saúde e diversidade } \\
\qquad\left(9^{a}\right)\end{array}$} & $\begin{array}{l}\text { 1. Criação do Centro de Referência de Saúde } \\
\text { para o atendimento, orientação e prevenção de } \\
\text { adolescentes e jovens com equipe } \\
\text { multidisciplinar; }\end{array}$ \\
\hline & $\begin{array}{l}\text { 2. Criação de equipe de orientação à saúde e } \\
\text { prevenção em escolas que atendam público } \\
\text { jovem. }\end{array}$ \\
\hline $\begin{array}{l}\text { Juventude: esporte, lazer e tempo livre } \\
\qquad\left(4^{\mathrm{a}}\right)\end{array}$ & $\begin{array}{l}\text { 1. Construção de um centro esportivo com a } \\
\text { prática de esportes diversificados, focando } \\
\text { práticas diversificadas como artes marciais, } \\
\text { esportes radicais (skate, patins), ciclismo, } \\
\text { tênis, handball, vôlei, natação, construídos em } \\
\text { espaços de fácil acesso à população. Nestes } \\
\text { espaços deve haver profissionais específicos } \\
\text { para cada área (voluntários, estagiários, }\end{array}$ \\
\hline
\end{tabular}




\begin{tabular}{|c|c|}
\hline & $\begin{array}{l}\text { educadores, etc), realizando também a } \\
\text { manutenção dos locais existentes; }\end{array}$ \\
\hline & $\begin{array}{l}\text { 2. Maior abertura de espaços públicos } \\
\text { municipais e estaduais para que sejam } \\
\text { realizadas atividades físicas, recreativas para } \\
\text { interação dos jovens aos finais de semana; }\end{array}$ \\
\hline \multirow{4}{*}{ Juventude e vida segura } & $\begin{array}{l}\text { 1. Criação da semana da segurança pelo poder } \\
\text { público; }\end{array}$ \\
\hline & $\begin{array}{l}\text { 2. Fazer a conscientização dos jovens sobre } \\
\text { segurança através de palestras, debates e } \\
\text { bate-papo em diversos segmentos juvenis; }\end{array}$ \\
\hline & $\begin{array}{l}\text { 3. Divulgar as políticas públicas de segurança } \\
\text { em escolas; }\end{array}$ \\
\hline & $\begin{array}{l}\text { 4. Realização da Semana Municipal de } \\
\text { Segurança, através de parceria entre poder } \\
\text { público e sociedade civil. }\end{array}$ \\
\hline \multirow{4}{*}{$\begin{array}{l}\text { Juventude: direito à participação e leis de } \\
\text { juventude }\left(3^{\mathrm{a}}, 5^{\mathrm{a}}, 10^{\mathrm{a}}, 11^{\mathrm{a}}, 12^{\mathrm{a}}\right)\end{array}$} & $\begin{array}{l}\text { 1. Criação de um órgão na estrutura municipal, } \\
\text { responsável por coordenar e articular as } \\
\text { políticas públicas de juventude } \\
\text { (coordenadoria/secretaria municipal de } \\
\text { juventude); } \\
\text { 2. Simplificar a redação de leis municipais, } \\
\text { para que a juventude e também toda } \\
\text { população consigam acompanhar e fiscalizar a } \\
\text { aplicação de recursos do orçamento municipal. }\end{array}$ \\
\hline & $\begin{array}{l}\text { 3.Criação de leis que incentivem os estágios, } \\
\text { concedendo incentivos fiscais para empresas } \\
\text { que contratarem um número determinado de } \\
\text { jovens (assim como existe cota para } \\
\text { deficientes físicos); }\end{array}$ \\
\hline & $\begin{array}{l}\text { 4. Criação do Fundo Municipal de Juventude, } \\
\text { gerido pelo Conselho Municipal de Juventude } \\
\text { a fim de captar recursos públicos e privados } \\
\text { para o desenvolvimento das políticas públicas } \\
\text { de juventude; }\end{array}$ \\
\hline & $\begin{array}{l}\text { 5. Alterar a Lei } n .^{\circ} 3309 / 2011 \text { transformando o } \\
\text { Conselho Municipal de Juventude em um } \\
\text { órgão deliberativo; }\end{array}$ \\
\hline
\end{tabular}

Propostas prioritárias

SANTA BÁRBARA D'OESTE. Comissão Organizadora da $2^{\text {a }}$ Conferência Municipal de Juventude. Relatório final da $2^{\text {a }}$ Conferência Municipal de Juventude de Santa Bárbara d'Oeste-SP. Santa Bárbara d'Oeste: [s.n.], 2011. 


\section{ANEXO O - RESOLUÇÕES APROVADAS NA $3^{\text {a }}$ CONFERÊNCIA MUNICIPAL DE JUVENTUDE}

\section{Propostas do GT "Direito ao desenvolvimento integral: Educação, trabalho, cultura e comunicação"}

1. Fomentar e incentivar a criação de espaço privados para diversão noturna, criando um complexo de diversão nortuna, através de isenção fiscal;

Criação de espaço público $\mathrm{p} /$ pratica esportiva e cultural nas periferias;

2. Melhorar divulgação dos espetáculos em especial os gratuitos, anúncios banners e escolas (TV, SITE, FACE, INTEGRAÇAO C/ ASSESORIA DE IMPRENSA);

3. Melhorar divulgação das oficinas realizadas no CEU e na Estação Cultural;

4. Criar um site para divulgação de eventos;

5. Realizar parceria para que os eventos cheguem a escola;

6. Criar mais espaço público na zona leste, em especial destinar áreas no Parque dos Jacarandás destinado a cultura;

7. Reativar o site da Secretaria Municipal de Cultura;

8. Ter ao menos 1 jornalista por secretaria $\mathrm{p} / \mathrm{que}$ chegue e integre as secretarias;

9. Utilizar espaços na periferia durante a Virada Cultural Paulista, promovendo a descentralização das atividades;

10. Divulgar as atividades culturais e educacionais em regiões periféricas, focando culturas juvenis próprias da periferia;

11. Implementar o projeto de $1^{\circ}$ emprego;

12. Retirar incentivos de empresas que não fomentem o primeiro emprego;

13. Propor novos incentivos a quem ofereça $1^{\circ} \mathrm{emprego}$ (descontos IPTU ou $10 \%$ da mão de obra);

Propostas do GT "Direito ao território: cidade, campo, transporte, meio ambiente e comunidades tradicionais"

1. Implementar ônibus exclusivo $\mathrm{p} /$ estudantes em horários de entrada e saída de escolas;

2. Implementar passe livre p/estudantes universitários, técnicos;

Propostas do GT "Direito a experimentação e qualidade de vida: Saúde, esporte, lazer e tempo livre";

1. Criar eventos (competição) / equipes de bairros na periferia incentivando a pratica esportiva;

2. Incentivar a realização de campeonatos interescolares com apoio e organização por parte do poder publico;

3. Eventos Musicais contemplando diversos estilos musicais;

4. Criar espaço no parque do jacarandás, destinado a atividades p/juventude;

5. Utilizar a quadra do jardim perola para atividades com a juventude;

6. Implantar o programa do governo federal "Praça da juventude" através de disponibilização de terreno por parte do Poder Municipal; 
7. Fortalecer através da Divisão de Políticas para a Juventude a utilização de espaços públicos para realização de diversas atividade voltadas para as juventudes;

8. Ampliar o número de médicos em postos de saúde, com maior $n^{\circ}$ de psicólogos específicos para juventude;

9. Disponibilizar leitos de estabilização para dependentes químicos.

Propostas do GT "Direito à diversidade e vida segura: segurança, valorização e respeito à diversidade e direitos humanos"

1. Realização de debate por parte do conselho contra a Redução da Maioridade;

2. Conscientização através de palestras sobre a segurança, através da realização da Semana Municipal de Segurança;

3. Implantar ações educativas no município para orientar e capacitar os jovens sobre os direitos humanos e juvenis, com linguagens e estratégias que impactem a população juvenil;

4. Criação de ouvidoria e disque denúncia para coibir formas de discriminação juvenil.

Propostas do GT "Direito à participação e fortalecimento institucional"

1. Transformar a Divisão de Políticas de Juventude em Coordenadoria com equipe de no mínimo 5 profissionais;

2. Alterar a Lei Municipal de criação do Fundo Municipal de Juventude prevendo que sua gestão será compartilhada entre CoMJuv e Coordenadoria Municipal de Juventude;

3. Maior respaldo por parte da câmara, com representantes na participação de forma efetiva do CoMJuv;

4. Cumprimento do previsto na lei municipal n. ${ }^{\circ} 3309 / 2011$ por parte da Prefeitura, referente ao tempo máximo para responder documentos de solicitação de informações protocolados pelo CoMJuv;

5. Promover, manter e efetivar o diálogo entre a secretarias e os conselhos.

6. Reativar UMES, fortalecendo dos grêmios e através Divisão de Políticas Públicas para juventude;

7. Maior divulgação da existência do Conselho Municipal de Juventude.

8. Destinar uma profissional concursada, conforme previsto em lei, para desempenhar o papel de Secretaria Executiva do CoMJuv;

9. Realizar no âmbito municipal pesquisa denominada "Mapeamento juvenil" para conhecer e cartografar o perfil do jovem barbarense;

SANTA BÁRBARA D'OESTE. Comissão Organizadora da $3^{\text {a }}$ Conferência Municipal de Juventude. Relatório final da $3^{\text {a }}$ Conferência Municipal de Juventude de Santa Bárbara d'Oeste-SP. Santa Bárbara d'Oeste: [s.n.], 2014. 
ANEXO P - RESOLUÇÕES APROVADAS NA $4^{\mathrm{a}}$ CONFERÊNCIA MUNICIPAL DE JUVENTUDE

\begin{tabular}{|c|c|c|}
\hline \multicolumn{3}{|c|}{ Propostas Aprovadas } \\
\hline Número & Eixo & Decrição \\
\hline \multirow{3}{*}{1} & \multirow{3}{*}{ Direito à Cidadania, à Participação Social e à Representação Juvenil } & $\begin{array}{l}\text { 1. Fomentar verbas e recursos nas três esferas, municipal, estadual e } \\
\text { federal, para o Fundo Nacional de Juventude; }\end{array}$ \\
\hline & & $\begin{array}{l}\text { 2. Que seja assegurado em todos os Conselhos Municipais cadeiras } \\
\text { específicas para a faixa etária jovem }\end{array}$ \\
\hline & & $\begin{array}{l}\text { 3. Fortalecimento do Conselho Municipal de Juventude e outros } \\
\text { Movimentos Sócias para que questões relevantes para a juventude e } \\
\text { sociedade possam ser debatidos e defendidos. }\end{array}$ \\
\hline \multirow{3}{*}{2} & \multirow{3}{*}{ Direito à Educação } & $\begin{array}{l}\text { 1. Revisão do Plano de Educação referente a questão de gênero junto à } \\
\text { conscientização da sociedade sobre o tema. }\end{array}$ \\
\hline & & $\begin{array}{l}\text { 2. Ampliar os modelos de educação integral, utilizando o modelo das } \\
\text { Etecs }\end{array}$ \\
\hline & & $\begin{array}{l}\text { 3. Ampliação da educação de qualidade através de convênio com o } \\
\text { Sistema S. }\end{array}$ \\
\hline \multirow{3}{*}{3} & \multirow{3}{*}{ Direito à profissionalização, ao Trabalho e à Renda } & $\begin{array}{l}\text { 1. Sistemas facilitadores para o maior aprendiz como mecanismos de } \\
\text { menor aprendiz coletivos, incubadoras de menor aprendiz }\end{array}$ \\
\hline & & $\begin{array}{l}\text { 2. Maiores oportunidades de emprego e flexibilização dos horários de } \\
\text { estágios para os jovens que estudam em período integral; }\end{array}$ \\
\hline & & $\begin{array}{l}\text { 3. Rever os critérios do Programa "Ação Jovem" e ampliar a } \\
\text { visibilidade do mesmo, sem descriminação dos jovens }\end{array}$ \\
\hline \multirow{3}{*}{4} & \multirow{3}{*}{ Direito à Diversidade e à Igualdade } & $\begin{array}{l}\text { 1. Combate a discriminação LGBT e conscientização da sociedade } \\
\text { sobre o genocídio que acontece atualmente, junto a capacitação dos } \\
\text { profissionais da educação para tanto. }\end{array}$ \\
\hline & & $\begin{array}{l}\text { 2. Criação de cartilhas sobre a igualdade de gênero e a desmistificação } \\
\text { do termo orientação sexual }\end{array}$ \\
\hline & & $\begin{array}{l}\text { 3. Combate ao racismo e conscientização da sociedade sobre o } \\
\text { genocídio que acontece atualmente nas periferias; }\end{array}$ \\
\hline 5 & Direito à Saúde & $\begin{array}{l}\text { 1. criaçao de um centro especializado para atendimento jovem,com a } \\
\text { formaçao de profissionais propagadores campanhas e debates sobre } \\
\text { drogas, HIV, gravidez na adolescência entre outras problematicas que } \\
\text { envolve a juventude }\end{array}$ \\
\hline
\end{tabular}




\begin{tabular}{|c|c|c|}
\hline & & $\begin{array}{l}\text { 2. Criação do projeto "Saúde Etinerante para a Juventude", onde os } \\
\text { agentes de saúde se deslocariam aos bairros periféricos visando o } \\
\text { alcanse da saúde à todos os jovens, podendo utilizar os prédios } \\
\text { públicos como CRAS, Centros Culturais, ou até mesmo escolas } \\
\text { estaduais e municipais para chegarem até o território de cada } \\
\text { juventude. }\end{array}$ \\
\hline & & $\begin{array}{l}\text { 3. Criação de cartilhas e Forum especifico aberto para dicussão do } \\
\text { tema "Depressão e Suicídio no meio juvenil". }\end{array}$ \\
\hline \multirow{3}{*}{6} & \multirow{3}{*}{ Direito à Cultura } & $\begin{array}{l}\text { 1. Utilização da mídia para o esclarecimento do termo "rolezinho", e } \\
\text { diferenciar este movimento das maniestações culturais da juventude } \\
\text { que visa momentos de lazer. Ainda, criar espaços especificos para que } \\
\text { estas manifestações possam aconetcer de modo seguro. }\end{array}$ \\
\hline & & 2. Mais políticas públicas referente à cultura nas favelas \\
\hline & & $\begin{array}{l}\text { 3. Que os educadores que se propõe a trabalhar e já trabalham com a } \\
\text { juventude, estudem o desenvolvimento humano, para que as questões } \\
\text { da juventude e o desenvolvimento desta faixa etária possam ser melhor } \\
\text { compreendidas e trabalhadas }\end{array}$ \\
\hline \multirow{3}{*}{7} & \multirow{3}{*}{ Direito à Comunicação e à Liberdade de Expressão } & $\begin{array}{l}\text { 1. Que a PM e/ou GM respeitem as formas de manifestações dos } \\
\text { jovens; }\end{array}$ \\
\hline & & $\begin{array}{l}\text { 2. Criação um link para cadastrar artistas que torne a autorização para a } \\
\text { realização de eventos culturais menos burocrática; }\end{array}$ \\
\hline & & $\begin{array}{l}\text { 3. Criação de lei que ampare os jovens secundaristas e universitários a } \\
\text { se manifestarem de forma a questionar situações da questão social, sem } \\
\text { os mesmo sofrerem oprimidos e/ou punidos por isso. }\end{array}$ \\
\hline \multirow{3}{*}{8} & \multirow{3}{*}{ Direito ao Desporto e ao Lazer } & $\begin{array}{l}\text { 1. Realizar passeios monitorados educativos para interagir no ambiente } \\
\text { externo, com o acompanhemento da Secretaria de Esporte e Secretaria } \\
\text { de Saúde, nos três ambitos, Municipal, Estadual e Federal. }\end{array}$ \\
\hline & & $\begin{array}{l}\text { 2. Maior intensificação e investimentos do Governo Federal para a } \\
\text { PAC } 2 \text { e priorizaçâo no CIE (Centro de Inicialização ao Esporte e } \\
\text { Lazer), para que o mesmo tenha o alcance aos bairros periféricos } \\
\text { municipais, garantindo lazer à juventude que ali vive e assegurando a } \\
\text { formação de jovens atletas para o nosso país. }\end{array}$ \\
\hline & & $\begin{array}{l}\text { 3. Realização dos jogos estudantis, aproveitando os espaços dos } \\
\text { parques e escolas, integrando jovens e crianças. }\end{array}$ \\
\hline 9 & Direito à Sustentabilidade e ao Meio Ambiente & $\begin{array}{l}\text { 1. Incentivar e fiscalizar empresas a utilizarem meios sustentáveis } \\
\text { (criação de um ranking). }\end{array}$ \\
\hline
\end{tabular}




\begin{tabular}{|c|c|c|}
\hline & & $\begin{array}{l}\text { 2. Criação de bolsas universitárias federais para jovens que se } \\
\text { destacarem na criação de projetos sustentaveis }\end{array}$ \\
\hline & & $\begin{array}{l}\text { 3. Criação de Lei onde obrigue os setores públicos a utilizarem papeis } \\
\text { reciclaveis para a formação de seus documentos, entre outros. }\end{array}$ \\
\hline \multirow{3}{*}{10} & \multirow{3}{*}{ Direito ao Território e à Mobilidade } & $\begin{array}{l}\text { 1. Fomentar a importância e relevância da Bicicleta como Veículo de } \\
\text { Transporte Não - Motorizado, através de Capacitação, Palestras, Rodas } \\
\text { de Conversa e Ações Educativas }\end{array}$ \\
\hline & & $\begin{array}{l}\text { 2. Mapeamento das áreas que são potenciais para serem utilizadas } \\
\text { como espaço de cultura; }\end{array}$ \\
\hline & & $\begin{array}{l}\text { 3. Que a metodologia de divulgação dos eventos voltados à juventude } \\
\text { sejam revistos para que as informações chegue até o jovem com maior } \\
\text { eficácia. }\end{array}$ \\
\hline \multirow{3}{*}{11} & \multirow{3}{*}{ Direito à Segurança Pública e ao Acesso à Justiça } & $\begin{array}{l}\text { 1. Regeição da PEC } 171 \text { que dispõe sobre a Redução da Maior Idade } \\
\text { Penal, junto a esclarecimentos à população sobre as medidas } \\
\text { socioeducativas já tomas pelo Governo, contendo como amparo o ECA } \\
\text { - Estatuto da Criança e do Adolescente. }\end{array}$ \\
\hline & & $\begin{array}{l}\text { 2. Que a Guarda Municipal, Policia Militar e órgãos que trabalha com a } \\
\text { segurança sejam capacitadas através de cursos e palestras para } \\
\text { trabalhar com a faixa etária jovem e periférica e que revejam suas } \\
\text { formas de abordagem aos jovens, pois as mesmas estão sendo } \\
\text { realizadas de maneira agressiva e racista. }\end{array}$ \\
\hline & & $\begin{array}{l}\text { 3. } 2 \% \text { do Imposto de renda e IPI's voltados a PP's para segurança da } \\
\text { juventude; }\end{array}$ \\
\hline
\end{tabular}

SANTA BÁRBARA D'OESTE. Prefeitura. $4^{\text {a }}$ Conferência Municipal de Juventude a âmbito nacional acontece em agosto. Disponível em: < http://www.santabarbara.sp.gov.br/v5/index.php?pag=noticia\&dir=noticias\&id=58797>. Acesso em: 20 set.2015. 
ANEXO Q - AUTORIZAÇÃO PARA UTILIZAÇÃO DE FOTOGRAFIAS PRESENTE NO SITE DA PREFEITURA

Município de Santa Bárbara d'Oeste Setor de Protocolo

Santa Bárbara d'Oeste, $1^{\circ}$ de fevereiro de 2016. Senhor Coordenador

Considerando a pesquisa de Mestrado intitulada " $O$ que a rebeldia teima? Capturas e resistências nas conferências de juventude em Santa Barbbara d'Oeste" "desenvilvida na Universidade de São Paulo(USP), que tem por objetivo compreender e problematizară ses sentidos atribuiddos conferências de juventrafias disponiveis no endereço eletrônico www.santabarbara.sp.gov.br, en matérias referentes as conferências municipais de juventude, realizadas no samente,
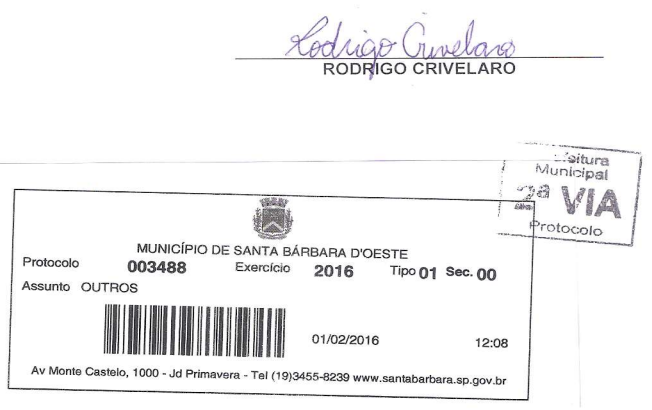

A Sr. Coordenadoria de Políticas Públicas de Juventude/ Secretaria de Governo Santa Bárbara d'Oeste - SP
Santa Bárbara d'Oeste, 22 de fevereiro de 2016.

Ofício n 249/16- ess

ess $348 / 16$

Prezado Senhor

Em resposta ao protocolo mencionado, referente à solicitaçăo de autorizaçăo para utilizaç̃o de fotografias disponiveis no site da Prefeitura Municipal, informamos, de acordo com o parecer da Secretaria de Governo, que seu pedido foi DEFERIDO

Atenciosamente

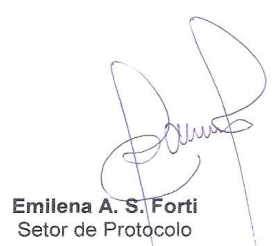

Ao Senhor

Rodrigo Crivelaro. 